\title{
The 2hilosophy of Higher Education
}

\author{
John Percival Powell
}

Thesis submitted for the degree of

Doctor of Philosophy

in the

Australian National University

Canberra

January 1969 
'Education, in its larger sense, is one of the most inexhaustible of all topios. Though there is hardly any subject on which so much has been written, by so many of the wisest men, it is as fresh to those who come to it with a fresh mind, a mind not hopelessly filled with other people's conclusions, as it was to the first explorers of it.... Education, moreover, is one of the subjects which most essentially require to be considered by various minds, and from a variety of points of view. For, of ell many-sided subjects, It is the one which has the greatest number of sides.'

$$
\text { J.S. VI11 }
$$

This thesis is my own original work. 


\section{PREFACE}

The time and facilities required to undertake this thesis were made available by the generosity of the Australian National University in awarding me a Research Scholarship. Without the encouragement and guidance of my supervisor, Professor P.H. Partridge, the work would never have been completed. I an also grateful to Professor J.A. Passmore and Mr. S.I. Benn for their criticisms of earlier drafts. The staff of the Menzies Jibrary responded to thy many requests with unfailing cheerfulness and efficiency. 


\section{TABLE OE CONTENTS}

Preface

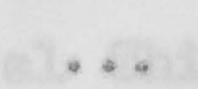

a. .

...

Summary

Introduction

Chapter I The Development of the Idea of the University

The liedieval Mradition

... 9

The Curxiculum

Mathemetical. Studies

Classical. Studies

I1beral Bducation

Mental Discipline

Soience and Soclety

\section{Chapter II Contemporary ConceptLons of the University}

51.

The University and the Pursuit of Truth

The University and Applied Research

$\ldots 104$

The Univexity as a Centre of Culture ...

... 106

Chapter III Higher Education

The Universiby and Pxofessional Training

The University and Higher Education

$\ldots 140$

Functional Priorities and Competibilities

$\ldots 163$ 
Chapter IV Mraining the Mind

Generality and Intellect ... ... ...

Critical Thinking

198

Judgment

$\cdots$

210

Creativeness

$\cdots \quad \cdots$

Independence

$$
\cdots
$$

214

226

Chapter V Developing the Derson

The Intellectual Virtues $\ldots$

Moral Education

...

$$
\text { - . }
$$

Education and Indoctrination

Education and Values

Chapter VI Curxiculum and Methods

Breadth of Understanding ...

Specialization

... $\ldots$

Learning
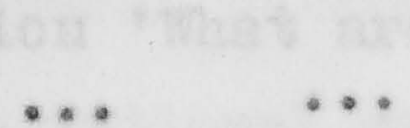

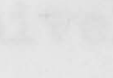

Teaching
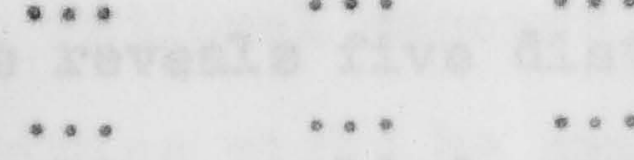


\section{SUIMVARY}

This thests is an examination of some of the concepts and theories which feature prominently in debates about the functions of the universities and the nature and purposes of higher education. In order to give the study some historical perspective and at the same time identify a number of the major issues, the first chapter briefly suxveys the development of the 1 dea of the university and of university education from its origing in the middle ages to the close of the nineteenth centuxy.

Chapter II connects traditional views of the functions of the university with more recent attempts to answer the question that are untvergitios forn, A scrutiny of the 1iterature reveals sive distinot replies to this question: scholarship, applied research, cul tural centre, professional. training, higher education. The pirgt two of these are then treated in detail. The doctrine of

'Enowledge fox its own sake' is analyzed through a consideration of what it means to $\mathbf{s a y , ~ i n ~ g e n e r a l , ~ t h a t ~ a n ~ a c t i v i t y ~}$ is intrinsically valuable rather than instrumentally valuable. Justificatory arguments are then considered for making the pursuit of knowledge one of the bases of an 
educational programme and for locating this activity wi thin universities. The chapter concludes with a briefer account of what is involved in viewing universities as having responsibilities for applied research and as being centres of culture.

Chapter III completes the inquiry into the functions of the universities by looking at their role as institutions concerned with teaching at an advanced level. It is pointed out that most of the discussions about the place of professional training in the universities has concentrated upon the establishment of criteria which can be used to restrict the number of vocational studies to be admitted to the universities: the general features of such studies have thus received very little attention. In order to clarify the general nature of such studies and so open the way to a more rational account of the contribution which the universities might be expected to make to professional training, a case-study is made of the training of teachers. This involves discussion of the nature of educational theory and the relations between theory and practice. It is argued that the major issue here cannot be resolved without making a sharp distinction between educating and training. The next section attempts to sharpen this distinction by offering a preliminary analysis 
of the concept of 'higher education'. This shows that it is comonly conceived either in terms of a specialized intellectual training or in relation to the much broader notion of 'personal development'. Finally, the five major functions of the universities which have been identified and examined in isolation are reviewed in ordex to determine the extent to which they are inter-dependent and nutually compatible.

The two main conceptions of the nature of higher education are then treated in detail. Chapter IV analyzes the qualities of mind which higher education is comonly held to promote. These have usually been associated with the doctrine of 'the trained mind" which attributes a high level of generality to certain intellectual skills. A number of argunents are directed against this doctrine and it is show only to be acceptable if restricted to a small. number of formal skills which do not depend upon substantive knowledge for thelr exercize. The next three sections offer analyses of the concepts of 'critlcal thinking', 'judgment' and 'creativeness': these are all shown to be heavily field-dependont and hence lacking in generalsty. The final section examines the notion of 'independence" and argues that this is fundamental to our understanding of the achievements which justify bringing an educational programe to a close and describing an individual learner as being 
'edueated.' It is this posability of students gaining intellectual and personel independence that chiefly distingui shes higher educetion from earlier steges in the student's educational experience.

Chapter $V$ deals with accounts of education in termas of the fostering of 'pergonal development' rather than the promotion of intellectual excellenee alone. It is fixst shown that even the display of the intellectual skills discussed earhiex implies comi tinent to certaln standards of performance and the possession of what are called 'intelleotual character traits.' There is thus no sharp line between cognitive development and the scquigition of values and attitudes. The nature of the values with which education is concerned is then investigated and it is argued that moral education cannot be restricted to the formel patterns of reasoning required for rational moral aeliberation: it aust also encoursge comnitment to particular beliefs. In order to deal with the objection that this would be inconsistent with the standards of objecU1vity with which the university is associated the next section exanines the coneept of 'indoctrination'. Minally, it is argued, that if the univeralues are to be seen as educetionsl institutions then they cannot escape responsibility for fostering 1 deals of conduet and 
commitment to personal and sociel action.

Chaptex VI concentrates upon releting the earliex treatment of the concept of 'higher education' to curriculum planning and to some central problems of teaching and learning. The fixst section argues for a broadly based curriculum by developing two possible lines of justification. Peters' defence of theoretical eurriculum activities is seen to be defective in several respects and an al ternative defence is proposed in terms of what is required by the notion of 'education for democracy.' The next section deals with the probler of specialization and shows that this arises from conceptions of the university which see it largely in terms of being a centre of scholarly activity. It is concluded that specialized studies axe rightly demanded by professional training but are incompatible with the notion of higher education. The remeinder of the chapter examines the concepts of 'learning" and 'teaching' and distinmushes these from processes and ectivities which are disconnected from oux view of the nature of human action and the development of the understanding, attitudes and values which characterige an independent 'educated person."

Chapter VII contains a summary of the major elements in the concept of 'higher education' which has been 
constructed in the thesis and argues against construing the latter in terms of an intellectualist model of 'rational. man.' It is suggested that higher education should be open to all xather than to the elite thought able to attain the intelleotual achlevements associated wi th the prevaling image of rational man. Finally, some implications of the thesis for educational policy are brought out. It is concluded that the whole eystem of institutions of higher Leaming is in need of drastic re-structuring if practice is to be aligned with acceptable theory. 


\section{INTRODUCTION}

If an outsider were to examine surveys of educational research, sean the professional journals and make polite inquiry of the research activities of those who work in colleges and departments of education, he could perhaps be forgiven for concluding that most of the really perplexing problems in education have been solved. If the most troublesome and fundamental questions in education have to do with its purposes, content and justification then a Martian who browsed amongst the recent educational literature would quickly discover that such questions as these are rarely even mentioned and almost never discussed with the seriousness and attention which they merit. Instead, he will find that the bulk of recent research consists mainly of the empirical findings of psychologists and other thaorists whose interests appear to be only very tenuously related to the solution of educational problems as opposed to psychological or sociological ones. 1

This remarkable stete of affairs has been the result, in large part, of developments in the study of education which appear prima fecie to mark an advance on what 1. See, for example: R. Thouless, 'A Wap of Educational Research in Britain', Paedagogica Europaea 1966 , Bdinburgh, Chambers, 1966; H.J. Butcher and Pont, H.B.(eds), Educational Research'in Britain, London, University of London Tress, Iybo. 
was done previously. These developments are connected with the increasing tendency for the somewhat amorphous body of inquiries which constitute educational studies to become differentiated out into distinctiy discipline-oriented areas of research. Historians and psychologists were the first scholars with an interest in educational matters to establish distinetive modes of approach arising from their theoretical 1

activities as psychologists and historians. Nore recently, educational research has become further fregmented as economists, philosophers, sociologists and anthropologigts have appropriated areas of educational theory within which they can exercize their specialized professional skills. This movement towards greater specialization has been at one with the spirit of the times and has been almost universally applauded in the expectation that the rigour of argument and sophistication of technique involved in these new approaches would quickly result in a marked strengthening of our powers to resolve urgent educational issues.

Unfortunately, these hopes have so far remained largely unfulfilled. It may be that these are still early days, although the meagre fruits of the growth of educational psychology during the past fifty years scarcely encourage optimism. The demand for rigour inevitably leads research

1. For a concise history of educational studies see: J.I. Tibble, 'The Development of the Study of Education', in J. Tibble(ed), the Study of Education, London, Routledge, $1966^{\circ}$ 
workers to investigate problems in the parent discipline which appear to offer some prospect of illuminating educational. issues, yet all too often the darkness remains as impenetrable as before. Somotimes it is even thickened, as happened as a result of the misconceived exertions of the mental testing movement. The craving for academic respectability and the tendency to look for approval to reference groups outside of education has undoubtedly tended to the neglect of genuine educational issues in favour of research which is almost wholly determined by disciplinary requirements and is thus of only very tangential educational import. One obvious consequence of this is that educational theorists, that is, people who have something worthwhile to say about education, are becoming increasingly rare on the campus; their 'subject' has been taken over and dismembered by specialists whose concern for education is often purely notional. Another consequence is that the resolution of basic problens is being Increasingly assigned to parents, politicians and the man-inthe-street on the grounds thet professional academic expertise carries with it no licence for seying what ought to be done in the schools. So we have a peradoxical situation in which the most pressing and crucial problems are left to those who are least well-equipped to deal with them. It is true that many papers in the journals conclude by saying that what has been offered should (or may) be of interest or use 
to practical men, but its relevance and application is rarely convineingly demonstrated or worked out in any detail. often has the impression that such concluding paragraphs are added only out of deference to the fact that the journal frequently contains the word 'education' in its title. These observations apply to the philosophy of education as ruch as to other areas of inquiry: rach of the work in this field is exceedingly evagive and timid when it comes to the point of pursuing analysis through to prescriptions for action. ${ }^{1}$ They also apply to most of the research into higher education. 2 Until very recently this area hed

1. This has yet to be widely noticed but the following criticism is probably a straw in the wind: 'lluch of the lack of certainty in educational thinking is to be traced to the state of philosophy of education. Several recent writings are produced simply by applying the techniques of linguistic analysis to educational discourse. Their subtlety is often matched only by their trivielity. Then the writers move toward more fundamental ground, they cast aside their linguistic techniques but find no al ternative means of justifying thei $x$ opinions'. Anon., 'Confusion Confounded by Politicians', Times Educational Supplement, 29 November 1968.

2. For example, the 196711 terature abstracts published by the Society for Regearch into Higher sducation contain only one item under the heading of philosophy and theory of higher education out of a total of 252 investigations. The same body's 1967 Register of Research into Higher Education lists 138 projects of which only four are concerned with the philosophy and theory of higher education. 
been notoriously neglected and the new upsurge of interest in the affairs of the universities and in higher educetion generally is therefore welcome. ${ }^{1}$ But, again, a great deal of this work appears to be hopelessly premature in thet it is almost exclusively empirical at a time when many of the theoretical foundations are totally incapable of supporting the structures which are being hastily built upon them. ${ }^{2}$

These renarks are prolegomena to my main theme which is the body of theory relating to the functions of the universities and the nature of higher education and the ways In which it should be conducted. If this were to be pursued with the thoroughness and attention to deteil which it merits it would constitute a daunting task requiring the labours of many people over many yeers. Iven then it seems doubtful

1. The founding of S.R.H.Z. was welcomed in an editorial in New Soclety in the following terms: The annual Home Universities Conference demonstrates the need. Half a dozen top chaps from all the universities and colleges of advanced technology gather in London. Two or three ten minute papers, written for the most part off the top of the head, introduce sherry party discussion (without sherry) - this year on university teaching methods and finance. The lethargy which this induces was excused by one of this year's chairmen on the ground that it was after lunch and at the end of term..., New Society, 24 December 1964.

2. Part of the explanation of the confused condition of educational studies in general les in the primitive state of our understanding of the nature of educational theory, desp ite some helpful recent attempts to improve matters. See: B. Bandman, The Place of Reason in Education, Columbus, Ohio, Ohio State University Press, 1967: F.H. Hirst, 'Philosophy and Educational Theory', British Journal of Educational Studies, XII, 51-64, 1963. 
that any all-encompassing and totally acceptable theoretical structure would energe: recent developments in philosophy caution against such expectations. The present work is rather to be viewed as a sexies of connected explorations into some of the more insistent problems which higher education presents in such abundance.

William Hazlitt once remarked that when a thing ceases to be a subject of controversy it ceases to be a subject of interest. Higher education is a topic, or confused bundle of topies, which presents a seemingly inexhaustible supply of problems which are not only highly contentious and deeply interesting but also extremely baffling in their complexity. Anyone who attends to the continuing debate on the responsibilities of the universities and the nature of higher education cen soarcely fall to notice that it has three quite striking features: a reluctance to relate theoretical claims to empirical evidence; the language in which

1. IIt seems to be too readily assumed that if we can only discover the true meanings of each of a cluster of key terms ... then it must without question trangpire that each will fit into place in some single, interlocking, consistent, conceptual scheme. Not only is there no reason to assume this, but all historical probability is against it, especially in the case of a language derived from such various civilizations as ours.... why must there be a conceivable amalgan, the Good Iife for "lan?' J. 5 . Austin, 'A Ples for Exouses', in A,R. Thite (ed), The Philosophy of Action, London, Oxford University Press, 1968, p. 42 . 
controversy is conducted is remarkable for its vagueness and looseness; many of the most fundamental questions are either ignored or the answers to them are assumed to be so obvious that little needs to be said in their defence. As a result, there is much heat but very little light. Orten it is not even possible to make a rational chojce between competing views as they are rarely expressed with sufficient clarity for their practical consequences to be inferred or predicted with any degree of confidence - and the grounds of their fustification are almost invariably obscure. This can scarcely be counted a satisfactory state of affairs, yet there is Iittle prospect of it being remedied until there have been a number of sustained attempts to clarify what is being said in the discussions of higher education and to evaluate the merits of conflicting points of view. This thesis is, hopefully, one such attempt. 


\section{CHAPTER I}

\section{The Development of the Idea of the University}

It is easy to assume in the heat of contemporary controversy about the functions of the university that most of our troubles have sprung fully-armed from the ground: the fact is that many of the issues which are currently being debated have a long lineage of argument and development. It is therefore worth looking at the history of the universities (a fascinating but neglected field of study ${ }^{l}$ ) in order to give some perspective to the present inquiry and to indicate the intractability of many of the problems with which it is concerned. The weight of this tradition of thought requires acknowledgement not because the antiquity of a theory or point of view provides any ground for accepting it but because it helps to bring out the extent to which our own thinking is shaped by assumptions of long-standing which we are often reluctent to subject to radical criticism. Some historical understanding of the origins and growth of

1. A. Briggs has referred to '...the rich, 1 thuminating but neglected olassic literature about universities and about learning, a literature which inspires humility and dispels all desire for novel ty for novelty's sake'. The Map of Learning, Canberra, Australian National University, 
our educational institutiong also leads to a fuller appreciation of how and why they have come to possess their present structure and purposes and this is almost bound to be helpeul in any attempt to clarify and evaluate these purposes. In what follows I heve tried to pick out the main strands in this tredition in order to identify the central issues which require deeper investigation and to indicate the continuity of many of the problems and of some of the solutions which have been psoposed for them. I have no pretensionsto competence as an historian so the content of the presentation relies entirely upon the work of others.

The Hedieval Tradition

Hastings Rashdall claimed that by the late midale ages the universities were almost entirely concemed with

1. A recent comentator upon student demands for university reform has pointed out that such knowledge may al so be put to other uses: '... students on both sides of the Atlantic share the characteristic of being very poor students of the university itself. They are unfamiliar with the classic studies of higher education .... and equelly have given scant attention to more recent writings ....A heavy price is paid for this ignorance. The complicated history of higher education has created institutions which not only have a distinetive strueture, but al so institutions which have perfected numerous devices designed to neutralize rash attenps to change the university. Knowledge of which kinds of issues are likely to provolse strong or weals responses on the part of the university, and of the specific kinds of responses thet will be forthcoming, would increase by many times the potency of student action'. $\mathbb{R}$. Polk, 'Student Protest in the UK and the US', Higher Education Review, I, 63-67, 1968, p.67. 
professionel education and were the major avenue to advancement in the Church and in the civil administration: $\ldots$ the universities became simply the ordinary door to olerical preferment. 1 It would be a mistake to suppose that the univergities provided a professtonal training in the modern sense of teaching a set of techntques and a body of specialized knowledge peculiar to a given voostion: the latter was available elsewhere in the medical schools and the Inns of Court. ${ }^{2}$ A university education simply put a man in the way of entering a profession.

During the second half of the sixteenth century the Arts course began to acquire an intrinsio value and to become increasingly discomected from vocational considerations. 3 The universities conceived their function in terms of two basic tasks: the preserving and refining of knowledge inherited from the past, and the 'virtuous education of youth'. The idea that the university should be concerned with research, with discovery, with ading to the corpus of knowledge, had no currency until the mid-nineteenth century.

1. Hastings Rashdall, The Universities of Europe in the Made Ages (edited by .Mowicke and A.B. Maden), London, Oxiord University Press, 1936, p.444.

2. See: . Charlton, 'Liberal Education and the Inns of Court in the Sixteenth Century', British Journal of Educational Studies, IX, 25-38, 1960; Phylis Allen, 'Medical Education in Seventeenth Century Ingland', Journal of the History of Hedicine and the Allied sciences, I, 115-143,1946.

3. M.H. Curtis, Oxford and Cambridge in Transition 15581642, Oxford, Clarendon Press, 1959, p.123. 
Before that time few people felt that there was anything wrong with the universities if they confined their activities to teaching and scholarship. ${ }^{1}$ The primacy of the teaching and pastoral function had been clearly expressed in a letter to Cambridge from the Pxivy Council in 1575 which stated thet the universities '... have at the very first been instituted prineipally for the nurture and edueation of a multitude of youth in good manners, learning, and Christianity'. ? The Curriculum

In order to understand a system of education it is necessary not only to attend to what educators say they are trying to achieve but also to examine the manner in which the system acturliy works and in this way hope to discover the educational and social assumptions upon which it is founded. A close inspection of the curriculum, for exarale, will often reveal the educated community's view as to what knowledge is of most worth and the type of mind and character most highly val ued.

The medieval curriculum continued undisturbed at Oxford and Cambridge until almost the end of the seventeenth century. During his first two years the student was taught rhetoric and logic together with some music and arithmetic. He then proceeded to the study of the 'three philosophies'

1. Ibid., p.227.

2. C.R. Thompson, Universities in Tudor Bngland, Washington, D.C., Folger Shakespeare library, 1959, quoted on p.7. 
of Aristotle: the Hetaphysies, Ethies and Polities. The only major addition to the medieval curriculum was creek. ${ }^{2}$ Scientific studies consisted in the explication of ancient texts, a teaching procedure which was unlikely to foster either the scientific spirit or any noteble increase in knowledge. It was only during the years of the Commonweal th that oxford enjoyed a bxief period of enthusiasm for science when a group of brilliant experimentalists migrated there from Gresham College. ${ }^{2}$ After the founding of the Royal Society most of them returned to London, but the establishment or new professorships in botany (1669) and chemistry (1683) showed that theix influence had been fax from negligible. Al though Cambridge hed no similex decade of heightened scientific activity the University was nevertheless preparing for a change of attitude towards the new leaming which was to produce educationel consequences markedly different from those at Oxford. While oxford continued to be dominated by Aristotelian studies Cambridge men showed great interest in the work or Remus and Descartes, a

1. \%. Costello, the Scholastic Currioulum at Marly Seventeenth Century Cambridge, Canbridge, lass., Harvard University Press, $1958, .2 .63$.

2. Phyllis Allen, 'Scientific Studies in the Bnglish Universities of the Seventeenth Century', Journal of the History of Ideas, $x$, pp. 219-253, 1949; R. Ilerton, 'Science Technology and Soclety in Seventeenth Century England', Osiris, IV, 1938; Sir Harold Hartley (ed.), The Royal Society: Its Origins and founders, London, The Royal Society, 1960: \$ee especially the contribution by llotie on the importance of Cresham College. 
far more fertile preparation for the growth of the physical sciences. ${ }^{1}$ The pre-eminence of mathematics in Cambridge began with Newton's creation of a School of llathematics and Theoretical Thysics in the 1670s, ${ }^{2}$ The prestige of mathematical studies gradually became so great that they assumed a central place in the curriculum. In 1799 it was announced that every cendidate for a degree in Arts would be requixed to show his competence in arithnetic, vulgar and decimal fractions, simple and quadratio equations, the first book of Luclid's Elements, and selected works by Locke and Paley. ${ }^{3}$ The Tripos, with its narrowly specielized training, became the highest intellectuel hurde in the country and it was not until 1857 that the mathematical requirement was abolished and the Classical Tripos by itself qualified for a degree. 4

The radical character of this change in the curriculum is made clear by looking at the condition of preNewtonian mathematical studies. John Wallis, an

1. S.P. Ianprecht, The Role of Descertes in Seventeenth Century England, Columbia Studies in the History of Ideas, vol. iii, New York, Columbia University Dress, 1935, pp. $194 \mathrm{ff}$. 2. W. W.R. Ball, Origin and History of the Mathematical Iripos, Cambridge, The University Press, 1880. 3. 1.R. Ball, Cambxidge Papers, London, Macmilian, 1918, pp. $278-279$.

4. M.I. Cierke, Classical Education in Britain 1500-1900, pambidge, The University Press, 1959, ch.9. 
undergraduate at Emmanuel from 1632 to 1640 , said that mathematics was only studied as a means of escape from the boredom of the old classical eursiculum.

For Mathenabicks (at that time, with us) vere scarce looked upon as Academieal Studies, but rether Mechanical; as the business of Traders, Nerchants, Seamen, Cerpenters, Surveyors of Lends, of the like; and perhaps some AImanack-nakers in London ... the study of liathemeticks was at that time more cultivated in Iondon than in the Jniverstities. 1

Loxd Herbert of cherbuxy's views on mathenatics may be taken as typical of the edneated community's attitude. He said that al though some knowledge of axithmetic might be useful in the keeping of accounts, geometry was'not much useful for a gentlemen, unless 1 t be to understand fortifications'. ${ }^{2}$ Yet by 1800 all Cambridge unlergraduates, except these reading civil law end medicine, were obliged to devote their time almost exclusively to mathematics.

Before discussing the retionale of the mathematical and classical curricula it will be useful. to consider examples of the skills and knowledge which the more able students were expected to possess. The following is a description by a successful candidate for Fellowship of his examination by the Mlaster of Mrinity College, Cambridge in

1. Phyllis Allen,'Seientilic Studies in the English Universities in the Seventeenth Century', op. cit., quoted. on $\mathrm{pp} \cdot 228-9$.

2. Ibid, quoted on p.231. 
... he began by requiring of me an account of the whole course and progress of my studies in the severel. branches of philosophy, so called in the genesal, and as I proceeded in my detail of what $I$ had read, he sifted me with questions of such a sort as convinced me he was determined to take nothing upon twust .... he bade me give him a summary account of the several great empires of the ancient world, the pertods when they flourished, their extent when at the sumit of their power, the causes of their declension and dates of their extinction. Then aumoned to give answer to so wide a question, I can only say that it was well for me that I had worked so hard upon my scheme of General History .... This process being over, he gave me a sheet of paper written through in Greek with his own hand, which he ordered ne to turn either into Latin or English ... and I was required to use dispatch. The passage was maliciously enough selected in point of construction and also of character, for he had scrawled it out in a puzzling kind of hand with abbreviations of his own devising.... When I had given in my trenslation in Letin I was remanded to the empty chamber wi th a subject for Latin prose, and again required to dispatch them in the manner of an impromptu. I

The introduction of written examinations in the

1790 s provided further evidence of what was required from cendidates for Fellowships. The following questions were set in an examination paper of 1797 :

That are the four ancient monarchies? That is their date, succession, and by what means and events did cyrus establish his empire?

What were the fanilies of the Caesers, and with whom did they begin and end?

What axe the sources and directions of the principel. mounteins in Asia, Africa, Burope, and the two Americas? What are the principal volcanoes on the surfece of the globe? 2

1. O. Wordsworth, Scholee Academicae: Some Account of the Studies of the English Universities in the cighteenth centur. cambridge, The University press, l910 (first published in 1877 ), quoted on p.345. This work gives details of the studies and examinations in every subject at oxford and Cambridge.

2. Ibid., quoted on $\mathrm{p} \cdot 348$. 


\section{Mathematical Studies}

At the beginning of the wineteenth centuxy the curricula at the two English universities were maricedy diffexent, al though they were both founded upon a lmowledge of the clessical. lengunges and some fomiliexity with the culture of Greece and Rome. What argunents were put forward to justify these two paxadigms of ecucation?

Tillian Thewell, one of the leading defenders of the Cambridge curriculum, asserted that a suitable liberal educetion for the upper clesses must be based upon mathenaties, augmented with the classics and some physicg. He clalmed that the excellence of mathenatics as a subject for undergraduate study arose from the fact that it dealt only with undisputable truths. ${ }^{1}$ The natural solencos, on the other hand, were deered to be most unsultable because there was controversy about important facts and princlples together with a constant accession of new material. from discoveries. He feared that stuaents would lose all respect for professors who dealt only with disputed material and even urged that at least a century should be allowed to pass before new discoveries in science were admitted to the

1. In a paper which he reed before the Britiah Assooiction for the Advancenent of Sclence in 1835, Thewell ergued for astronomy as 'the only perfect solence' on the grounds that its truths were estabilished beyond all possible doubt. 
undergraduate curriculum.

This bewilderment in the face of the rapid advance af the sciences, together with a deep suspicion of their educational value, was shared by most university people in the fixet half of the nineteenth century. The growing popular enthusiesm for science as a source of power and useful knowledge had encouraged the view that science was lit le more than a collection of useful. fects with valuable epplications in engineering, medicine, industry and sgriculture. But there were others who pointed out the dengers of stressing the practical utility of science and who were able to indicate other aspects of scientific activity which might prove more attractive to educators. Thomas Young argued that science was an excellent discipline for the mind and could be pursued independently of utility simply for the setisfactions which came from being able to extend knowledge. ${ }^{2}$ Henry Brougham elained that seience, al though useful, could also

1. 7. Whewell, in a 17 -sheet printed in 1848 , quoted by $D$. A. Minstanley, Early Victorlan Cambridge, Cambridge, The Universi ty Press, $1940,0.202$ see also Thexwell's Thoughts on the Study of Mathematics as part of It bexal gaveation, cambridge, 1835. It would be misleading 60 suggest that Whewell was hostile to science; his position was that scientific studies should only be introduced into the curriculum at a late stage, and It was with this in mind that he advocated a new Ceneral scientific Tripos to be open to those who had taken honours as Junior optimes. For a recent defence of restricting the curriculum to well-established subjects see: Michael Oakeshott, Rationalism in Politics, tondon, Methuen, 1962, pp. 301-33. 2. Thomas Young, A Course of Lectures on Naturel. Philosophy and the Mechanical Arts, Iondon, Taylor \& valton, 1807. 
lead to general truths of great moral value. Robert Hunt saw science as the force behind the advance of civilization and its pursuit was thus a duty for all those who sought to increase human happiness. 2 Thomas Love Peacock was able to make much the sane points in his novels by midiouling those who conceived science as nothing more than a collection of usefur facts. Nevertheless, both the chaotic state of the sciences in the early nineteenth century and the nature of popular attitudes towards them were such as to condern scientific studies in the eyes of most university people, ${ }^{3}$

Compered with the confusion and uncertainties of the sciences, mathenatics appeared to offer a body of truths which were beyond dispute and immune to the daily discoveries of the experimenters. There were other educational considerations which were advanced to support the study of mathematics. Todhunter, later in the century, 11sted the following: it is easily and accurately examined, ${ }^{4}$ t enables

1. Henxy Brougham, Objects, Advantages and Pleasures of Science, Loadon, Beldwin \& Cradock, L829.

2. Robert Hunt, The Poetry of Science, Iondon, Reeve, 1848 .

3. See: F.M. Cannon, The Nomative Role of Science in Early Vietorian Thought', Joumal of the History of Ideas, XXV, 487-502, 1964; G. Poote, 'science and its punctions in Eariy Nineteenth Century England', Osixis, XI, 438-54, 1954; P.S. Taylor, "The Teaching of Science at oxford in the Nineteenth Century', Annals of Science, VII, 82-1.12, 1952; J.Z. Pullner, 'Humphry Davy's Adversaries', Chymia, VIII, 147-64, 1962.

4. For a discussion of the influence of examinations upon the curriculum see: D. S.I. Cardwell, The organisation of Science in England, Jondon, Heinemann, 1957. 
the teacher to evoke interest and creativity at all levels of attainment whereas this is not possible with the study of languages, and $1 t$ demands constant hard work and self-denial. In addition to these explicit attempts at justification there were other factors which help to explain the central position of mathematics at Cambridge, notably, the immense prestige attached to the name and work of Newton and the belief that mathematics provided a key to the understanding of the universe. The latter was probably a result of the influence of the Cambridge Platonists who were familiar with the educational theory expounded in the Republic, a theory which associated mathematics with insight into ultimate reality and hence with morality. There were also a number of other factors which could be collectively described as 'institutional inertia', now a widely-recognised property of educational systems. For exemple, it is not uneommon for university teachers to assume that the kind of training which they themselves received is superior to any other; but if called upon to defend what they are doing, some of the reasons which they produce will probably be rationalizations of beliefs which are held on quite different grounds. There is no need to pursue this point here, but It needs to be made if only because the value judgments which are suppressed in this way are sometimes extremely important

1. I. Todhunter, The Conflict of Studies, London, Macmilian, 1873, p.12. 
motivators behind policy changes (or opposition to them) even though they are raxely exposed to view.

The mathematical curriculum was not allowed to continue unchallenged for very long: throughout the first half of the nineteenth century there was a rising tide of criticism, much of which cane from within the Scottish universities. One of the most vigorous of these critics was Sir William Hamilton who refused to concede that mathematics could play any important role within liberal education:

... an excessive study of the mathematical sciences not only does not prepare, but absolutely incapacitates the mind, for those intellectual energies which philosophy and life require. We are thus disqualified for observation, either internal or extemal - - for abstraction and generalization, - - and for common reasoning; nay disposed to the alternative of blind credulity or of irrational sceptieism. I

If, as he claimed, the aim of a liberal education was to develop all the faculties of the mind in a balanced and harmonious manner then mathematios stood condemed because... none of our intellectual studies tend to cultivate a smaller number of faculties, in a more partial or

1. W. Hamilton, Discussions on Philosophy and Literature, $\frac{\text { Education and University Reform, }}{\text { Stewart, } 1853,0.282 \text {. The essay quoted was first published }}$ in 1836 . J.S. Nill comented that Hamilton knew very little pure mathernatics and no applied: An Examination of Sir liliam Hamilton's. Philosophy, vol. il, 1877. 
feeble manner, than mathematics. 1 . He contrasted mathematics and philosophy as suitable disciplines for training the mind and firmly rejected the former on the grounds that it did nothing to foster observation, generalization and the skills required for everyday reasoning. In laying this emphasis upon training the mind for common reasoning in the daily life of practical affairs Hamilton was drawing upon a strong tradition in the Scottish universities which placed great value on practicality and a general rather than a specialized education. This tradition was being challenged in the eighteen thirties by those who favoured a narrower curriculum similax to that at Cambridge. But resistance to innovations from South of the border was not to be easily overcome and Hamilton's views commanded wide support, typically expressed in the following extract from an anonymous letter to whewell:

We allow to mathematics as a Science every perfection you can claim for it; but we are far from thinking that, as a study, it affords anything like the best schooling for powers which must so much more largely and necessarily be employed in the field of contingent reasoning. 3

Mathematics was frequently assailed because of its lack of connection with contingent facts which, it was

1. Ibida, p.273.

2. This struggle has been thoroughly documented by G.E. Davie, The Democratic Intellect, Edinburgh, The University Press, 1961 .

3. Ibid, quoted on pp. 170-1. 
alleged, made it an almost useless discipline in which to train men who were to spend their lives in business, industry, comerce and the professions. It was also feared that the introduction of more specialized and abstract mathematical studies would tend to sever the relationship between experimental science, practical. Iife and technology which had become one of the notable features of the Scottish universities. ${ }^{1}$ But even the reform party in the North did not wish to do anything which might tend to undermine the general education which they believed to be fostered by the existing curriculum; they sought only to bring it into closer alignnent with what they thought to be the needs of contemporary society.

\section{It is worth noting that the very features of} mathematics which reduced its value as a discipline in the eyes of llamilton, its abstraction and lack of contingency, were to be counted in its favour as far as the Cambridge educators were concerned. Thewell, for example, admitting the value of an all-round development of the intellectual faculties, argued as follows:

This complete mentel oulture must, no doubt, consist of many elements; but 1 t is certain that an

indispensable portion of it is such a discipline of the reasoning power as will enable persons to proceed with certainty and facility from fundamental principles to their consequences.?

1. Ibid., p.I75.

2. Quoted in F. Cajori, Mathematics in Iiberal Education, Boston, Christopher, 1928, p.76. 
It seemed obvious to the Cambridge men that there were no better subjects for this purpose than mathematics and logic. Classical Studies

The oxford curriculum had emerged largely unscathed from the intellectual upheavals of the seventeenth century, and the entrenched belief in the supreme educational value of studying classical authors was reaffirmed in 1807 with the establishnent of the Honours School of literae Humaniores. This was the oxford paradigm of liberal education. Rather than mathematics it offered the student Greek, Latin, rhetoric, moral philosophy and some logic. ${ }^{1}$ The Report of the 1852 Royal Commission was highly critical of the oxfoxd curriculum: it found that classical studies were too narrow, mathematics and science counted for very little, there was no effective training in Theology, the teaching of Law was most unsatisfactory and the School of Medicine had virtually ceased to exist."

thatever the failings of Oxford, what was there to be said in defence of the almost erclusive study of

1. M.I. Clarke, Classical Education in Britain 1500-1900, op, cit., p.99. See also: J.L. Sandys, A History or llassical Scholarship, Cambridge, The University Press, 1908; R.t. Ogilvie, Latin and Greek: a History of the Influence of the Classics on English wife from 1600 to 1918, wondon, Routledge, 1964.

2. C.IB. Mallet, A History of the University of Oxford, London, Oxford University Iress, vol. i11, 1927, pp. 308 ff. 
classical antiquity? Most of the educational argunents were put by Dr. Moberly, the Headmaster of Winchester, in his evidence before the clarendon Commission in $1864 .^{1}$

Classical learning is the inheritance of all former ages. Combined with its allied subjects of philology, history, ete., it puts a person into the possession of the inherited wisdom of all ages.

As a mental discipline it was unsurpassed:

All classical learning tells on a man's speech; it tells on a man's writing; it tells on a man's thoughts; and though the particular frots go, they leave behind a certain residuum of power.

Sharing the popular view of the sciences as nothing more than congeries of facts, he denied that they could have any educational value. A scientific fact, he said,

… is a fact which produces nothing in a boy's mind. It is simply a barren fact, which he remembers or does not remember for a time, and which after a few years becomes confused with other facts and is forgotten. It leads to nothing. It does not germinate, it is a perfectly unfruitful fact.

One of the staunchest defenders of the classical

curriculum was John Stuart Mill, a man reared outsi de the pale of church, school and university, yet acquiring from his fathex a profound knowledge of and admiration for classical culture. ${ }^{2}$ His Rectorial Address at St. Andrews in 1867 contained a spirited defence of classical studies at a time when they were already entering upon their decline. He

1. Parliamentary Papers, vol. XI, 1864, pp. $331 \mathrm{ff}$.

2. See: I. Cuming, A Vanufactured Man: the Education of John Stuart Mill, University of Auckland Bulletin No. 55, Auckland (New Zealand), Pilgrim Press, 1960. 
argued that the val ue of knowing another language lies in the training it gives in the precise use of words and the insight it provides into a culture quite different from our own. But why choose Latin and Greek?

... in studying the great writers of antiquity, we are not only learning to understand the ancient mind, but leying in a stock of wise thought and observation, still valuable to ourselves: and at the same time making ourselves familiar with a number of the most perfect and finished literary? compositions which the human mind has produced...?

Classical literature not only provided stylistic models for authors but also standards for action in moral and political life:

... the treasure which they accumulated of what may be called the wisdom of life ... replete wi th remarks and maxims of singular good sense and penetration, applicable both to private and to political life. 3 Unlike Dr. Moberly, Mill was also prepared to make quite a strong case for the sciences:

1. Macauley had said that if oxford men had chosen to learn Cherokee instead of Greek "... the man who understood the Cherokee best, who made the most correct and melodious Cherokee verses, who comprehended most accurately the effect of the Cherokee particles, would generally be a superior man to him who was destitute of these accomplishments." In his 1833 speech on the East India Company, Specches, vol. i, London, Henry Vizetelly, 1853, p.186.

2. J.5. N111, Inaugural Address at the University of St. Andrevs, 1867, London, Longmans, 1890, p.15.

3. Ibid., p.16. Others had doubts about the moral excellence of classical authors: "Notwithstanding the serious moral imperfections of various kinds which pervade most of the writings of antiquity ... we think that a knowledge of the masterpleces of ancient literature is to be desired." Report of the Royal Commission on Endowed Schools in Ireland, 1858, p.203. 
The processes by which truth is attained, reasoning and observation, have been carried to their greatest known perfection in the physical seiences. As clasgical litereture furnishes the most perfect types of the art of expression, so do the physical sciences of the art of thinking. 1

But there was little disagreement about the function of the university as an institution: in the words of Sir William Harnilton '... education is the one sole function for which it was created.... ${ }^{2} \quad$ Hanilton's views are of great interest because they represent a long-established received opinion which was not seriously challenged until the eighteen sixties. The nature and purposes of a university he described as:

... Involving 1, what is properly the University, a school, to wit, for liberal or generel knowledge: and 2, a collection of special schools, for one, two, three or more of the leamed professions. In the former respect, the student is considered, as an end unto hinself; his perfection, as a man simply, being the aim of his education. This is the end proposed in, what is academically known as, the Faculty of Arts or of Philosophy. In the latter respect, the leamer is not viewed as himself an end, that end being now something out of himself: for not his perfection as a man, buthis dexterity as a professional man, - in a word, his usefulness as en instrument, has become the aim of his scientific preperation ... the only connection that these [Theology, Iaw, Medicine] have with each other or with the University, being, that they all hold out to be liberal, that is, they all hold out to educate to professions which presuppose always a liberal accomplishment, if not always an education in the liberal faculty, or faculty of arts.

1. Ni11, ibid., p.22.

2. Hemilton, op. cit., p,800,

3. Hamilton, op. cit., p.763. 
This passage contrins a clear statement of a number of ideas which have been, and still are, extremely important in the development of thought about the nature of the university. The university's task consisted solely in the education of undergraduates: it had no responsibilities for research or professional training - the professional

Schools had attached themselves to the university but they were not an essential part of it. Undergraduate education was defined non-instrumentally in terns of skills, knowledge and characteristics which should be common to all educated men - this was the notion of 'liberal education'.

\section{Iiberal Education}

The concept of 'a liberal education' is a complex one with a number of related but distinguishable ideas built into $1 t^{1}$ of these, the following five seem to be the most important: the teaching of skills which are thought to be general in the sense of being very widely applicable; independence from any professional purpose; the teaching of a large part of what every educated man may be expected to know; the development of 011 the powers of the mind, including 1 ts moral and spiritual aspects; the cultivation of what might be described as 'intellectual character training'flexibility, resourcefulness, initiative and integrity.

1. Por a valuable modern treatment see: P.H. Hirst, 'Liberal Bducation and the Nature of Knowledge', in R. D. Archambault (ed), Philosophical Analysis and Education, London, Routledge, 1965. 
When we look at the detalls of the oxford and Cambridge curricula in the nineteenth century they do not give the impression of being well-adepted to achieving these objectives. They cultivated an ability to recall a considerable number of facts together with a facility for translating the classical languages accurately and felicitously and an agility in solving certain types of mathematical problems. These skills were possessed, at least in some degree, by most educated people and it was largely for this reason that they continued to be associated with the idea of a liberal education rether than on account of any demonstrable connection between a training in the olassics or mathematics and the educational objectives of the universities.

The distinction between 11 beral education and professional training was of special importance, al though a considerable part of the emphasis upon this may have been a rationalization in defence of an educational establishment whose unmodified continuance was becoming increasingly difficult to justify. One certainly has this suspioion with much of what cardinal. Newman said about the universities: both the institution and the form of education which he discusses are idealizations of an Oxford which never existed but which he conjured up in ordex to buttress the contempoxary establishment against what he perceived to be threatening innovations. There are many inconsistencies in Mewnan's superbly expressed account of the idea of the university but 
his view of it as a communty of scholars and centre of liberal education is clearly displeyed in the following pessage:

An assemblage of learned men, zealous for their own sciences, and rivals of each other, are brought, by familiar intercourse and for the sake of intellectual peace, to adjust together the claims and relations of their respective subjects of investigation. They learn to respect, to consult, to aid each other. Thus is created a pure and clear atmosphere of thought, which the student also breathes.... He apprehends the great outines of knowledge, the principles on which it rests.... Hence it is that his education is celled "Liberal". A habit of mind is formed which lasts through life, of which the sttributes are, freedom, equitableness, calmness, moderation, and wisdom .... This is the main purpose of a University in its treatment of its students. 1

Newmen makes a good deal of the distinetion

between liberal education and professional training, associating the former with knowledge which is sought and

contemplated for its own sake without any reference to possible extringic values. It was, he cleimed, the special task of the universities to train students in those qualities

1. J.H. Newmen, he Ides of a University, (edited by C.R. Harrold), New York, 1947, p.90. The extent of the gulf between ideal and reality mey be gauged by comparing the above with the following picture of Oxford drawn in 1872 (the year before Nemen's book was published with its present titie) by Rey Lankester in a letter to Huxley after being eppointed to a science fellowship at Bxeter College: '...many men have their lives mined by taking residential fellowships .... They don't work - for why should they? Their time is sufficiently occupied with routine duties and routine amusements such as riding, dining and whist. To these may be added an occasional. visit to London -- for unknown purposes. This

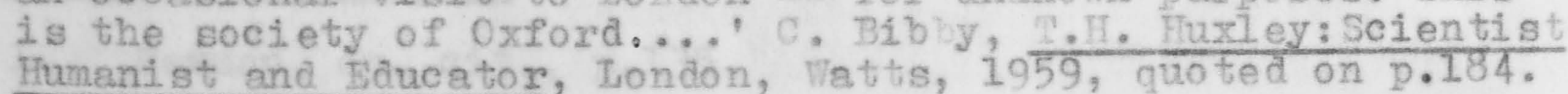


of intellect and charaoter which were of value in themselves rather than because they were required to be exercized in sothe specialized professional role.

This process of training, by which the intellect, instead of being formed or sacrificed to some particular or accidental purpose, some specific trade or profession, or study, or science, is disciplined for its own sake, for the perfection of its own proper object, and for its own highest culture, is calied Libersi Bducation.... And to set forth the right standard, and to train according to 1 t, and to help forwerd ail students toward it according to their various capacities, this I concelve to be the business of a Uni versity. 1

Wuch the same distinction was al so employed by

J.S. Mill in opposing the growth of professional, training within the universities:

Then are men before they are lawyers, or physicians, or manufacturers; and if you make them capable and sensible men, they will make themselves capable and sensible lawyers or physiciens. Thet professional men should carry away with them from a university, is not professional knowledge, but that which should direct the use of their professional knowledge and bring the light of general eulture to illuminate the technicalities of a special pursuit. 2

Iiberal education was thus seen as a generel preparation for life which equipped its possessor to enter upon professional work with the capacity to apply his specialized knowledge wisely. This point was made by . .H. Hurley in a speech given in 1876; general education, he said, is liberal '... In the sense of being an education fitted for free men to whom every

1. Newman, op. cit., p.1.35.

2. Mill, op. cit., p.5. 
career is open, and from whom their country may demand that they should be fitted to perform the duties of eny career'. I All of these views rely upon an essentialist theory of education: the belief that there is a standard model of the educated man towards which all students should aspire and in the light of which all educational arrangements can be judged. ${ }^{2}$ It was by making a connection, however Indirectly, with this doctrine that meaning was attached to such phrases as 'men are men before they are lawyers' and 'perfection as a man'. Its wi despread acceptance also simplified the distinetion between professional training and liberal education by recognizing thet the former was concerned not only with special techniques but also with special purposes. The professional interests of the dootor, lawyer or engineer were thus distinguished from those purposes and interests which were common to all men. The most important of these, as far as educators were concerned, were moral puxposes: all men, whatever profession they may follow, are moral agents, and the university must take this into account when organizing the curriculum. This, I take it, was what Mill had in mind when he spoke of 'that which should direct

1. T.H. Huxley, Science and Bducation, London, Macmillan, $1893, p .283$.

2. See:I. Mash, A.M. Kazamias and H.J. Perkinson (eds), The Educated Man: Studies in the History of Bducational Thought, 
the use of their professional knowledge', and what Hatthew Arnold was referring to when he said:

To have the powex of uglng, which is the thing wished, these data of natural science, a man inust, in general, have first been in some measure "moralised"; and for moralising him it will not be found easy, I think, to dispense with those old agents, letters, poetry, religion. 1

Tnowledge of the external, world as revealed by the sciences was undeniably useful, but it was not enough: the central concern of the university should be with Man and It was felt that this was a subject with respect to which scientific knowledge was largely irrelevant. If an essential. feature of university education is that it should be humane, that is, profoundly concerned with human velues and actions, then this should be reflected in the curriculum insofar as it encourages the student to develop his moral and aesthetic sensibilities as well as his powers of observation, analysis and memory. The defenders of the classical curriculum believed that it met these requirements to an extent which scientific studies could never match. Todhunter apole for a great many people when he regretted the decline of Greek scholarship and felt that it

... involves with it a gradual but certein decay of general culture, the sscrifice of learning to science, the neglect of the history of man and of thought for the sake of facts relating to the external world. 2

1. Quoted in F.S. Marvin (ed), Repoxts on Rementary Sohools, 1852-1882, London, H.1.. S.0., 1908, P.183.

2. I. Todhunter, The Conflict of Studies, op. cit., p.135. 
It is clear from what was seid earlier that the curricula at both the Inglish universities in the first half of the nineteenth century provided an education which was, in fact, very narrow and specialized. Its ideal was that of the 'cultivated gentleman' who shared with his peers a certain familiarity with classical culture and a comon intellectual background. In addition to being a valuable social accomplishment a university education, el though allegedly non1

vocational, prepared a man to enter any of the professions by equipping him with a 'trained mind'. If his social position was such that he was not obliged to work then his education would have proxided him with most of the social skills which the life of a gentleman required; if he was to be a soholor then the highly specialized study of the clas zics or mathematics provided a nentel discipline which was then unsurpassed in rigour and exacti tude.

\section{Mental Discipline}

The notion of 'mental discipline' was connected with a view of the mind derived from faculty psychology, namely, that the mind possessed certain powers or faculties each of which was capable of being developed by engaging in

1. In practice it was not uncommon to take a more hardheaded view as, for example, in one of Dean Gaisford's semons: 'Nor can. I do better, in conelusion, than to impress upon you the study of Greek literatuxe, which not only elevates above the common herd, but leads not infrequently to positions of considerable emolument.' C.D. Lewis and C, Fenby (eds), Anatony of Oxford, Jondon, Cape, 1938, quoted on p.162. 
the appropriate exercises. Although this theory had been discredited and derided by Locke ${ }^{1}$ it continued to exert a profound influence upon educational thinking and oblique references to it abound in the nineteenth century literature. Associated with the concept of 'mental discipline' wes an assumption concerning the generelizability of the skilis which were being taught. Once a man was equipped with a 'trained mind' then it was believed that he would be able to apply himself with equal success in any field whatever. Consider the following extract from a letter written by de Horgan in 1853:

Let it be supposed that the former student has forgotten everything, that not a word of liatin is left, and not a proposition of Buclid. That remains to him? If little or nothing, then his education has not deserved its name. But if, in spite of the loss of all that acguirement whioh he hes no daily need to recall, he be a man of trained mind, able to apply vigorously, to think justiy, to doubt discreetiy, and to decide wisely, he has been well educated ... If we talke care of the habits, the acquirements will take care of themselves.?

What is being advocated here is a training in certain intellectual skills: systenatic doubt, clear thinking and rigorous argament, together with what is perhaps more accurately described as a character trait - the ability to act judiciously or wisely.

1. John Iocke, An Essay Concerning Fuman Understanding, 1690, Book II, ch. 2I. 2. P.A. Cavanagh (ed), Spencer on Education, Cambridge, The Universi, ty Press, 1932, quoted on p.209. 
What were the exiteria which were employed in deciding whether a subject was able to provide a mental discipline? It was not until the classical curriculum began to be seriously challenged that this question was even posed, let alone answered. Prior to that time there was no major alternative to classical studies because other areas of scholarly inquiry remained largely unexplored. It was not unnatural, therefore, that when other fields of knowledge began to be developed on a growing scale it should still be assumed that the classies, if only because they had been the focus of academic interest for centuries, were the only suitable means by which to train the mind. They had a long history of success and enormous prestige when compared with the faltering progress of the experimental sciences and other 'modern' studies. It must have been extrenely difficult for men who had been trained in the classios to see that there could be any educational value whatever in othex fields of study.

One of the most explicit statements of the criteria governing the application of the concept of 'discipline' was contained in an enonymous broadsheet which was published in oxford in 1850 as a reaction against a proposal to establish a School of Law and History. Concerning the study of history it asked: 
Is the subject suitable for Education? Is it an exercise of the mind? Is it not better left until Bducation is completed? Is it not sufficiently attractive to ensure a voluntery attention to it? Is it a convenient subject for Examination? Where is the standard author like Thucydides, etc.? If there is no standard author, how are the comparative merits of the candidates to be judged? 1111 it not supersede those subjects where a severer discipline is required? 1

This is an extremely interesting passage because it exhibits so many of the educational assumptions upon which the undergraduate curriculum was based: to qualify as a discipline a subject must be both difficult and uncongenial, easily examinable, and its study grounded upon texts of unimpeacheble authority. 3 These requirements, and especially the last, counted heavily against science: if students were only to learn that which had been established beyond all doubt then they would find small, encouragement to venture into experimentel seience. There were also other criteria not mentioned by this authors a subject's val ue as a steppingstone to further knowledge, the extent to which it. Introduced

1. Quoted in R. Southern, The Shape and Substance of
Academic Hi story, Oxford, The Clarendon Press, 1961, p.9. 2. See John Wain's autobiography, Sprightly Running, Iondon, Macilian, 1962, p.145: '... the exclusion ol modern litexature was a tradition, dating from the time when "Inglish" had only crept into the university on the understending that it would be mainly philological, since otherwise students might enjoy it and then it wouldn't be work.' See also: E. M. W. Tillyard, The Iluse Unchained, London, Bowes \& Bowes, 1953, p.28.

3. IIt was the pride of oxford thet her students did not learn their philosophy from men who might mislead the young with ideas of their own, but rather by the "regular and docile study of a fixed theory" . M. . Clarke, Classical Bducation in Britain 1500-1900, op. cit., p.101. 
the student to the traditions of European culture and the contribution which it could make to the training of character and the cultivation of wisdom. Ho st of the curriculum disputes in the first half of the nineteenth century were generated by differing views about the extent to which the classics and mathematics were able to meet these criteria. Mathematics had a strong clatm to being difficult but it appeared notably deficient in all other respects. The classics were al so difficult but it was becoming increasingly implausible to argue that they constituted a necessery first step towards knowledge in all other fields. Their cultural claims were undeniably strong but their connection with character training and the scquisition of wisdom was, at the very least, open to debate. But whatever may be meant by 'wisdom' there is not much room for doubt as to the uselessness of mathematics as a means to its attainment. To discoyer what wise men have thought, gaid and done in the past would seem to offer at least some prospects of following in their footsteps whereas the study of mathematics appears to efford none whatever.

Nodern literature, history and the natural seiences were all neglected because they were thought to have little educational value. Newman felt that science was of negligible importance because it could contribute nothing towards increasing our understanding of human nature. To 
believe, he said, that:

... grief, anger, cowardice, self-conceit, pride or passion, can be subdued by an examination of sheils or grasses, or inhaling of gases, or chipping of rocks, or calculating the longitude, is the veriest of pretences which sophist or 1 llountebank ever confessed to a gaping auditory. 1

It would be difficult to find a more eloquent statement of the early Victorian belief in the essential triviality of the classificatory sciences and hence their uselessness as instruments of education. Another comnon objection to scientific studies was that they were too easy and so failed to provide a disoipline for the mind. Hamilton was convinced that the introduction of the natural sciences Into the curriculum would make the universities decline into:

... popular seminaries for the cultivation of the superficial, the amusing, the pelpable, the materially useful .... The natural sciences are essentialiy easy; requiring comparativel y little talent for their promotion, and only the most ordinary capacity for their acquisition. 2

Science and Society

The pressures for university reform which were

1. J.H. Newnan, Issays and Stretches (edited by C.F. Harrold), New York, Longmans, 1947, vol. II, p.185.

2. Hemilton, Discussions on Philosophy and Literature, op. cit., p.821. This attitude survived for a remarkably long time. Then Iindemann was deploring the low status of science at Oxford in the nineteen twenties he was told by the wife of the Tarden of A1I Souls: 'You need not worry, a men who has got a First in Greats could get up seience in a fortnight.' R.T. Harrod, The Prof, London, Macmillan, 1959, 2.53. 
building up in the midale years of the last century drew their energy from a quite different set of assumptions about the nature of culture, society and education. Iyon Playfair, one of the leading spokesmen for reform, argued that if society could not adapt itself to the traditional liberal curriculum then the universities must change themselves in order to meet the demands of society. The Bxitish Association for the Advancenent of seience 1 ssued a report in 1868 pointing out that the classioal curriculum was a dismal fallure as far as most students were coneerned. ${ }^{2}$ Robert Love, a noted classical scholar, launched a violent attack upon classical studies in which he asserted that if education is viewed as a preparation for life then the classics canot possibly qualify for a central place in the curriculur. ${ }^{2}$

The gulf between the needs of a rapidly changing society and the image of the educated man which continued to domingte the older universities was becoming wider every year. The threat of increasingly severe foreign competition in the economic field drew attention to educational inadequacies and exposed the universities to exiticism of a kind which had never before been directed against them. They could no

1. On the Best Means for Dromoting Scientific Bducation in Schools, London, H. S. S.0., 1868.

2. Robert Lowe, Zrimary and clagsicel. Bducation, Bdinburgh, Edmonston \& Douglas, 1867. For a reply see the pamphlet by Hractical Point of Viem, Edinburgh, Bdmonston \& Douglas, 1868 . 
longer hope to remain insulated from the social, politioal and economic changes which were taking place around them, They found themselves under mounting pressure to respond to much wider educational demands than those implied by the ideal of the gentleman scholar. The Report of the Royal Commission of 1852 undoubtedly adninistered a profound shock to the universities, unused as they were to any interference In their affairs. The fact that the consequences of the Report were far less calamitous than had been feared was of considerable value in malring the universities nore amenable 1 to criticism and reform.

The growing suspieion that Britain was failing to keep pace with her industrial competitors become acute after the display of British shortcomings at the Paris Bxhibition in 1867. In the United States the Morill Iand Grant Aet of 1862 had given a powerful stimulus to the development of higher education, while in Gemany there was not only the widespread provision for technical edrication of high quality but also a much larger proportion of young people was attending the universities. Increasing faniliarity with these facts helped to add to the demand for educational reform in the second half of the century. One of the most outstanding of the reformers

1. V.H.H, Green, Oxford Common Room, London, Bdward Amold, $1957,0.184$. 


\section{1}

was Marle Pattison. He was sharply criticel of the Oxford of his day, condeming both the narrowness of the curriculum and the inadequate conception of scholarship which then prevailed. Wissenschaft expresses the purpose and aim for which a university exists. Not that in a university, any more than in the world at large, man is for knowledge. Wuch rather is knowledge for man. Not to enlarge the sciences, of to heap up libraries, is oux object, but to maintain through successive generations an order of minds, in each of the great departments of human enquiry, cultivated to the utmost point which their powers admit of. Upon the prevalence and realisation of this idea depends the life of a university.

Pattison's views often brought him into sharp conflict with Jowett who, although he did not publish any treatises on education, was perhaps the most influential of the victorian educational reformers. ${ }^{3}$ Jomett's reform at Balliol, and especially the development of the 'Creati' course, had far-reaching effects upon the subsequent development of university education.

\section{Pattison's opposition to increasingly}

specialized studies went against the grain of contemporary thought for, as Cardwell has pointed out, there were a variety

1. See: Green, ibid.; J. Sparrow, Wark Pattison and the Idea of a University, London, Cambridge University -ress, 1967.

2. M. Pattison, Suggestions on Academical organisation, Edinburgh, 1868, pp. 226-7.

3. See: G. Faber, Jowett, London, Faber, 1957; W.R. Ward, Vietorian Oxford, Iondon, Frenk Cess, 1965. 
of influences favouring the idea of specielization. The notion of the division of labour played an important role in Victorian economic theory and it is scarcely surprizing that educators found it an attractive idea. The rapid growth of knowledge encouraged the sub-division of traditionel subjects: this became embodied in the examination system and was further re-inforced by the preference of both students and exaniners for areas of study with clear boundaries.

One of the best inquiries into the condition of soience in the nineteenth century was that carried out by the Devonshire Commission of 1872, despitie the fact that scarcely any of its recomendations were implemented. It came out strongly against specialization on the grounds that there was very little educationsl evidence in its favour. One of its most eninent members was .H. Huxley ${ }^{2}$ and he argued that to awerd a degree for work in one subject only would have the effect of converting the university into a technical college. But all his eloquent pleas on behalf of a broad general education were to have 11 ttile effect. In 1874 the Cambridge examination regulations were amended in order to allow and encourage a thorough knowledge of at least one subject. At the University of Lopdon the originel. B.Se, curxiculum, which

1. Cardwell, the Organisation of Science in Fingland, op. cit., p.1.17.

2. See: C. Bibby, M.H. Huxley: Scientist, Mumanist and Bducator, op. cit. 
Huxley had helped to draw up, had been designed to ensure 'such general culture as should be 11 kely to prevent its holder from becoming a mere specialist'. It required every candidate to show a competency in mathematics, physics, chemistry, the biological sciences and sone logic and ethics. Sut in 1876 a University comittee announced that a more thorough knowledge of fewer subjects was to be preferred to a slighter acquaintance with a wide range of studies.

The debate about the merits of specialization was only one element in the major crisis in educational theory which developed in the eighteen sixties and seventies, a crisis which was to produce some of the clasgics of university literature. On the one gide were the defenders of the classical curriculum: ${ }^{1}$ they were committed to a literary culture which looked back to Rome and Athens for its criteria of excellence and its inspiration, their image of Bducated Wan was imutable and their map of learning required no revision. Arrayed against them were the protagonists of science: ${ }^{2}$ they rejected linguistic scholarship in favour of

1. Fox example: Newnan, Natthew Amold, Todhunter.

2. For example: Iy on Pleyfair, Herbert Spencer, I. H. Huxley. The most importent contribution to the debate was the collection of essays edited by F. W. Farrar, Esseys on a Liberal Education, London, llacmilian, 1867. For an interesting study of many of those who were trying to promote the social role of soience, see: J.G. Crowther, Statesmen of Science, London, Cresset Press, 1965. 
experiment and research, refused to admit the authority of the Ancients and shared a crusading conviction that the future lay with science. Between these factions was a less readily identifiable group whose members were enxious to secure a place for modern histoxy, languages and literature.

Fuxley began the campaign for scientific

education in 1854:

Leave out the Thysiological sciences froll your curriculum, and you leunch the student into the world, undisciplined in that science whose subjectmatter would best develop his powers of observation; ignorant of fects of the deepest importance for his own and others' welfare; blind to the rich sources of beauty in Cod's creation; and unprovided with that belief in a living law, and an order manifesting itself in and through endless change and variety, which might serve to check and moderate that phase of despair, through which, if he take an enmest interest in social problems, he will assuredly sooner ox later pass. I

Many of the se themes were taken up and developed with vigour and cogency by Herbert Speneer. ${ }^{2}$ He set out to show the advantages of a scientific education for training the mind, refining moral judgment, forming the chaxacter, heightening religious awareness and providing useful $\mathrm{know}-$ ledge. On every count, he argued, scientific studies were supexior to learning 'extinct languages'.

1. T. I. Huxley, Hen's Place in Mature and other Essays,

London, Dent, 1906, pp. 28I-2.

2. Herbert Spencer, 'What thowledge is of Host Hor th? (1859), reprinted in P.A. Cavanagh (ed), Spencer on Bducation, Cambridge, The University Press, 1932. 
Huxley's most importent contribution was made In the speech entitled 'Science and culture' which he gave at the opening of Mason College in 1880.1 After criticizing the narrow view of culture which he alleged was shared by the great majority of educated Bnglishmen who had been trained in the classics and were thus ignorant of science and so held It in contempt, he went on to di scuss some of Mlatthew Arnold's views on the relation between literature and life. He coneluded that the study of literature alone was no longer an adequate basis for a balanced understanding of contemporary Iife.

Arnold replied in his Rede Lecture at Cambridge In $1882^{2}$. In on ingenious attempt to show that Huxley had misunderstood his position he extended the meaning of 'Iiterature' to inolude 'what in modern times has been thought and said by the great observers and lmowers of nature. 3 He was thus able, in a disarming way, to admit the educationel velue of the naturel sciences and so stand. on common ground with Tuxley. But having done so, he then went on to deny that science could have any central educational signifioance because it failed to connect with any of

1. Reprinted in: I.H. Huxley, Science and Education, 0p.cit.

2. 'Literature and Science', reprinted insll. Amold, Discourses in Amer1oa, New York, Hecmillan, 1896.

3. Ibid., D.94. 
the really crucial areas of human experience. This is the crux of his exgument:

But still it will be knowledge only which they give u.s; knowledge not pat for us into relation with our sense for conduct, our sense for beauty, and touched with emotion by being so put; not thus put for us, and there ore, to the majority of mankind, after a certain while, unsatisfying, wearying. 1 .

He concluded that, if faced with a choice, most people would do well to choose a literary education rather than a scientific one because: 'Letters will call out their being at more points, will make them live more. ${ }^{2}$

This debate, al though free from personal

rancour (unlike the recent snow-leavis exchanges), was incapable of being resolved because of the tems in which it was conducted. Nei ther Amold nox Huxley were aware of the extent to which such key terms as 'culture', 'science' and 'education' were changing their meaning in conformity wi. th the re-stmucturing of knowledge and social institutions. ${ }^{3}$ Arnold's conclusions were understandable, almost inevitable, given his assumptions regarding the nature of seience. His whole approach to the problem was shaped by the Victorian

1. Ibid., p.112.

2. Ibid., p.129.

3. It is worth noting that, according to the 0.D.D., a number of these words had been coined only a few years earlier: 'scientist' in 1840, 'expert' in 1825, and 'specialist' in 1862. 
humanist's Baconian conception of the scientific enterprise as being essentially concerned with endlessly accumulating useful knowledge, the ceaseless collecting of facts which 'only specialists have the gift for doing congenially. 'I He had no vision of science as an imaginative intellectual adventure productive of immensely powerful theories which could greatly extend man's understanding of the world. Amold's image of the scientist was that of the 'botanizer' who did little beyond collecting and naming objects which nature had placed all around him.

Huxley, on the other hand, was no Spencer: he took great care to insist upon the importance of literature and history. His intention was not to oust the classics from education but to insist upon the equally powerful claims of the sciences: 'for the purpose of attaining real culture, an exclusively scientific education is at least as effectual as an exclusively 1iterary one. ${ }^{2}$ In tems of Arnold's view of science Puxley was simply mistaken; it is still arguable whether on any view of science Huxley's case for it as a vehicle for liberal education could be madei out.

The significance of this debate lies in the evidence which it offers of a major breakdown in the traditional educational order. The consequences for the

1. Op. cit., p.126.

2. T.H. Huxley, Science and Education, op. eit., p.98. 
university curriculum were to be profound and far-reaching, even if the immediate results were disappointing. The new science Honours Schools succeeded in attracting remerkably few candidates: only about twelve a year at Cambridge, a number which did not increase significantly until the end of the century.

Far more rapid progress was made at other growing points in the curriculum, notably with history at oxford. ${ }^{1}$ The Oxford History Sohool grew so rapidly that by the early twentieth century almost one third of all undergraduates in the University were reading the subject. But the school had been established in the face of fierce opposition, which did little to encourage the first teachers to indulge in any innovetions: 'The Professor's lectures took the form of epigrammatic coments on the Annals (of England) as he hurriedly turned over the pages, ${ }^{2}$ All this changed when Stubbs was appointed Professor in 1867: under his leadership History became a flourishing and respectable discipline. ${ }^{3}$ History succeeded for a number of reasons: because it was thought to provide an excellent training for men who were to become leaders in the world of affairs, it

1. R. W. Southern, The Shape and Substance of Academic History, op. eit.

2. Ibid., quoted on p.11.

3. For his views on history as a discipline see: T. Stubbs, Seventeen Lectures on the Study of lledieval and llodern History, Oxford, The University Press, 1900. 
was free from the aura of dogmatism and useless learning which had become associated with classical seholarship, and the massive achievements of German historians had invested the subject with immense prestige.

Historical studies were soon to suffer the decline which had already afflicted the clessics as the claims of science gained increasing recognition and numerous other fields of inquiry began to be opened up in the universities. By the end of the century the common culture which had been shared by all educated people was in an advanced stage of disintegration. It was no longer possible to believe in a fixed corpus of knowledge and the idea that any one man could master even a sizeable part of what was known had become an obvious absurdity. The inage of Educated Nian which had served for so long as a blue-print for the curriculum was now blurred and confused and there was no longer much agreement as to what he could be expected to know. The oldex universities were gradually moving closer to the centre of national life and the new universities were becoming increasingly involved in professional training and applied science in response to the growing demands of a predominently industrial society. ${ }^{2}$

The universities were being reluctantly pushed

1. Southern, op. cit., p.8.

2. See: W.H.G. Amy tage, Civic Universities, London, Benn, 1955. 
into a new era in which the dominant ideas were those of research, the expert, the specialist and the highly trained professional. Social changes were beginning to erode the isolation of the universities and to urge upon the world of intellect responsibilities with which it had never before been confronted. The map of knowledge was being transformed and extended at an ever-increasing pace with the result that established views on the shape, content and purposes of education were proclaimed with reduced confidence and evoked responses which were less than whole-hearted. The universities were 111 -equipped to cope with these changes and in their attempts to do so a settled tradition of thought about the nature and functions of the universities was thrown into confusion, a confusion to which we are the reluctant heirs. 


\section{CHAPTER II}

\section{Contemporary Conceptions of the University}

What are the universities for? A century ago Sir William Hamilton was able to assert confidently that: "... education is the one sole function for which it [the university] was created.....1 Such confidence is no longex possible for this basic question is one which, as sir walter Moberly pointed out twenty years ago, evokes a confused and sometimes mutually inconsistent body of replies. Yet some firm answer must be given if we are to formulate a rational policy for the future development of our ingtitutions of higher learning. Contemporary views on the nature of the university contain a mixture of traditional notions, ideas which came to the fore during the nineteenth century, and. some which have only recently come into prominence. It is therefore worth examining some representative contemporary writings on the purposes of the university in order to see more clearly the theoretical bases upon which policy-makers are relying. It will then be easier to inquire into the possible justifications for each of these views and to determine the extent to which they are inter-dependent and mutualiy compatible.

1. W. Hamilton, Discussions on Philosophy and Literature, Bducation and University Reform, Edinburgh, Hactachlan \& Stewert, 1853, p.800. 
The work of Ortega y Gasset will make a useful starting point since he felt strongly that the universities have grown too far away from their medieval precursors and stand in need of radical reform.

Compared with the medieval university, the contemporary univergity has developed the mere seed of professional instruction into an enormous activity; it has added the function of research; and it has abandoned almost entirely the teaching or transmission of culture. I

In his view, most of the universities' troubles are the result of the diversion of more and more of their resources and energies into the prosecution of research.

The trend toward a university dominated by 'inquiry' has been disastrous. It has led to the elimination of the prime concern: culture. It has deflected attention from the problem of how best to train future professionals for their professions. 2

He insisted that "The teaching of the professions and the search for truth must be separated" ${ }^{3}$ and claimed that the prime function of a university is an educational one.

The university consists, primerily and basically, of the higher education which the ordinary man should receive. It is necessary to make of this ordinary man, first of all, a cultured person: to put him at the height of his times. It follows then, that the primery function of the university is to teach the great cultural di sciplines....4

1. Ortega y Gasset, Mission of the University, Princeton,

The University Press, 1944, p.57.

2. Ibid., p.78.

3. Ibid., p.76.

4. Ibid., D. 59 . 
He derides vague ideas of culture associated with the notion of it having something to do with leisure activities, a mere ornamental accessory which puts a civilized veneer upon brute existence and the life of work. Culture, he says, is rather to be conceived as an essential element of oux existence since it consists, in large part, in an understanding of the central energizing ideas of our time. It is thus the task of the university to put each student "at the height of his times".

Hence it is imperative to set up once more, in the university, the teaching of cul ture, the system of vital ideas, which the age has attained. This is the basic function of the university. This is what the university must be, above all else.1

Here, then, is one important strand in recent thought about the nature of the universities as institutions: 1t identifies the major task of the university as being an educational one and conceives this task as belng essentially that of transmitting to students the "vital ideas" of the world in which they live.

A rather different view of culture, and hence of the university's role in maintaining and trangmitting it, is to be found in some of the writings of F.R. Leavis. He sees the universities, or some of them at least, as being recognized symbols of a cultural tradition enshrining a set of values allied with bodies of specialist knowledge which

1. Ibid., p.59. 
are to be employed to ariticize and re-direct certain tendencies in contemporary life. The function of the univergity lies in:

... bringing the various essential kinds of specialist knowledge and training into effective relation with informed general intel ligence, humane culture, social conscience and political will. Here, in this work, we have the function that is pre-eminently the university's; if the wor's is not done there it will not be done anywhere. 1

... the raison d'etre of a university [is] to be ... a focus of humane consciousness, a centre where, faced with the specializations and distractions in which human ends lose themselves, intelligence, bringing to bear a mature sense of values, should aply itself to the problems of civilization. 2

There are at least two important differences

between the concepts of 'culture' used by Jeavis and Ortega.

Leavis conceives 'culture' almost entirely in terms of literary understanding and sensibilities whereas Ortega is concerned with a much broader spectrum of contemporary modes of thought, including science and technology. 3 the other major difference lies in Leavis's belief that the traditional

literary culture can only be accessible to, and be

1. F,R. Leavis, Education and the University, Iondon, Chat to 8. Windus, $1943, \mathrm{p} .24$.

2. Ibid., p.30.

3. Raymond Williams makes some sharp comments upon Leavis's pre-occupation with literature: To put upon literature ... the responsibility of controlling the quality of the whole range of personal and social experience, is to expose a vitel case to damaging mi sunderstanding'. Cuiture and Society $1780-1950$, London, Chatto \& Nindus, $1 \overline{958, ~} 0.255$. 
maintained by, a minority and it is therefore the task of the university to maintain the cultural tradition by initiating an elite group of students into its ways and values. Ortega, on the other hand, believed that some understanding of the central ideas of the time is essential for everyone and certainly not to be restricted to a minority group. The acceptance of one or other of these positions clearly has majox consequences both for the character of the education which a university provides and for the number of students who are to be offered it.

The view that the main task of the universities is to train an elite unified by a comon set of cultural values and attitudes occurs frequently in British writings about the universities. Bonamy Dobrée, for example, asks who is to undertake

... the creation, generation by generation in a continuous flow, of a body of men and women who shere a sense of the civilized values, who feel responsible for maintaining and developing them, who are unified by their culture, and who by the simple pressure of

1. This would, of course, be quite unacceptable to many people. Louis Aragon, for example, says: '... I want to stress the point that culture is one and indivisible. It is not the cod-given prerogative of a few but the common property of all, and whether you talk of masses, people or nation, it is in humanity it has its roots... We intellectuals are only the interpreters, only the collectors of what comes out of the earth; we sort out the deposits of mankind. We have not tapped the source of some mystic force, enabling us to scatter spiritual largess to a humanity speechless with gratitude'. The Many and the Few', in Reflections on our Age, lectures delivered at the opening session of UNisco, 1946, London, ingate, 1948, p.101. 
their existence and outlook will form and be enlightened public opinion? 1

Although Dobrée shares with Leavis the conviction that this responsibility devolves entirely upon the Arts faculties, some of the things he says contrin strong eohoes of Ortega -although Ortega would probably not share his view that university education should be restricted to members, or potential members, of the "governing class". Dobrée claims the t:

that is desperately needed now is a body of people awere of the vital ourrents of thought of theis tine, of important aisooveries in evexy field, and of who some at any rate are perceptive of modern art; a body in short, which understands and ereates the formatis ve ideas of the age, from which the governing class, in cabinet, in local councils, and in industry will largely be drawn, and in which inventors cen live hamonitously.2

This introduces a further major element in the 1dea of the universiby, namely, that it is a plnce in which the "formative 1deas of the age" are created. The university is concerned not only with the transmission of knowledge but also with its enlargement so that one of the regponsibilities of the university 1 s,$\ldots$ to extend by oxiginal enquiry the frontiers of Leaming ${ }^{3}$

This function can be expressed in a number of

1. 1. Dobrée, 'Arts Paoulties in llodern Universities', Doliticel ounterly, XV, 341-352, 1944, D. 343.

2. Ibid., D.344.

3. Toxd Curzon, Princivles and Hethods of University Reform, Oxford, Claxendon Press, 1909, D.210. 
ways depending upon the interpretation given to "learning" and "research". Oakeshott, for example, sees the university as "... an association of persons, locally situated, engaged in caring for and attending to the whole intellectual cap ital which composes a civilization". This espital is to be viewed not as a collection of information but as a vexiety of modes of thinking or directions of intellectual activity. Each member of this collectivity of persons is "... engaged in the activity of exploring a particular mode of thought in particular connections". " In addition, they are engeged in teaching others, not in ordex to train their successors but with the object of imparting familiarity with modes of thought: it is this which gives to university education its peculiar character.

University education is the sort of education that may be enjoyed by having the run of a place where the activities I have described are going on and are going on in the mamer I have described. 3

This view of the university as being essentially a community of scholars and apprentices engaged in acquiring, preserving and extending knowledgo and understanding; can readily be traced back to the medieval origins of the universities. Its traditional character leads Basil

1. M. Oakeshott, Rationalism in Zolities, London, Methuen, $1962, p .310$.

2. Ibid., p.312.

3. Ibid,,$p \cdot 312$. 
Mitehell to clain that most people would agree that:

A university is essentially a commity of scholers (in a broad senge of the word) concerned with the disinterested pursuit of the truth. As such it is bound to teach apprentice scholars their job, and it has also been entrusted with the task of educating students who are not going to be professional scholers.

The explicit interpretation of the extension of "learning" given in this passage is "the disinterested pursuit of truth", which is almost certainly indistinguishable from the doctrine of knowledge for its own sake. But there is another interpretation, frequently contrasted with this one, which

conceives this ectivity of enlarging knowledge meinly in terms of applied research, that is, of providing solutions to problems generated by the needs of society rather than by the needs of scholars to understand the world. A.B. Sloman, in outlining the plans for the new University of Bssex, claims that there is no intention there to depart from the traditional view of the university:

Dar from repudiating the accepted idea of a university we are determined to preserve and perpetuate it. The university ideal, which derives from the corporation of masters and scholars of the Mddle Ages, is a selfgoverning commity concerned with the advencing and disseminating of inowledge. ?

Never theless, he says, the universities are now heavily dependent upon public funds and carry responsibilities not shared by their medieval forerunners:

1. B. Witche11, letter to The Mimes, 6 February 1968. 2. A.B. Sloman, $\triangle$ University in the Malcing, London, BBC Publications, $196 \overline{4, p .10}$. 
... they have become far more important as instruments to satisfy the nation's need not only in the

education of its citizens but also in promoting its efficiency and increasing its wealth. I

And what the nation appears to need is more and more applied research and a steady increase in its stook of trained manpower equipped with a growing variety of vocational and specialist stcills. The main emphasis throughout Sloman's story of the origins of the University of Bssex is, despite his claim to be preserving the traditional view, upon research and vocational training.

A primary function of a university must be to engage in research. It can discharge its responsibility to train future reseerchers only if it is itself a plece where research is done. And research is the guarantee of 1 ts academic standards. It has always been the special quality of a university not only that its teaching is informed and vitalized by the discovery of new knowledge but that $i$ t counts among its members the most oxiginal and fertile minds in all branches of learning.?

This function of universities as centres of research demands, claims Sloman, both large departments and large univexsities if research is to flourish: consequences which are liable to have profound effects upon the quality of the education and community life which they provide.

Departments need to be big to build up effective research teams, to justify the expense of the latest equipment and to cover all the branches of a particular subject. Universities in turn will need to be big to accomodate big departments covering the generous range of studies expected of them. 3

1. Ibia., pp. 77-8.

2. Ibid., $p p \cdot 23-4$.

3. Ibid., p.10. 
Finally, there is the responsibility of the universities for vocational treining, especially preperation for the learned professions. The universities have always undertaken a certain amount of vocational troining but they axe now under increasing pressure to extend this and many people are worried by the problem of determining a limit to this work. Nost unitersity teachers in Britain would undoubtedly be reluctant to accept the first part of Conant's contention that:

... aside from these two institutions, [oxford and Cambridge] one can fairly say that the British universities are essentially professional schools, and, one should add, professional schools with the highest standards. 1

Nost of those who write on this topic ecknowledge that the universities do in fact engage in a great deal of professional treining and then they concern themselves with the question of how this can best be done without compromising their educational responsibilities. Some, of course, deny that the universities should have anything to do with vocational training. ${ }^{2}$ But a good deal of British

1. J.B. Conant, Bducation and Liberty, Cambridge, Hass., Harvard tniversiby Dress, 1953, p.29.

2. One of the best known exponents of this position is R.M. Hutchins: Vocationalism leads, then, to rurality and isolation; it debases the course of study and the staff. It deprives the university of the only excuse for its existence, which is to provide 2 haven where the search for truth may go on unhampered by utility or pressure for "results" " The University Press, $1936,2.43$. 
thinking on this subject is typified by the views expressed by Sir Hector Hetherington. He allows that the universities should be engaged in professional training but claims that they cannot possibly produce technically competent specialists since much of what they need to know can only be learnt on the job. Ingtead, the universities should concentrate upon helping the future professional to deal with some of the non-technical demands made by his work:

... he must have some understanding of its place and claim in the largex context of human experience and reflection. That is the real crux of University teaching, to provide for all kinds of students not a professional training, but an education for professional service .... The demand is not only for power, but for wisdom. 1

He points out that this type of preperation for professional Iife is undertaken in the United states by institutions devoted to pre-professional college education, but claims that it can be achieved in Britoin through specialist voeatienal courses provided that these are taught correctly. Unfortunately Hetherington is not very explicit about how this is to be done. He says that a great deal is achieved simply through allowing students to move within the ambience of a university with the opportunities which this provides for talking and mixing. But the most important task is to present subjects in 'a large and liberal way'. 'Something

1. H. Hetherington, The Social Function of the University, London, Lindsey Press, 1953, p.17. 2. Ibid., p.23. 
of what he bas in mind here is expressed in the following passage:

In part the solution is given by the inner logic of the discipline itself. If thet be disclosed in its Just perspective and signifieance, the student will see thet his discipline is neither stetic nor selfcontained, but the outcome of a long sexies of human questionings....1

Thether or not vocational training can be presented in some such way so as also to provide an

educational experience is a problem to be examined in detail. later; the only point which needs to be brought out here is that it is widely held that one of the funetions of the university is to provide for a regtricted range of vocationel training.

So far five perspectives in the contemporary viem of the nature and functions of the universities heve been identified. Before looking at these more olosely it is worth considering whet may be teken to be the received opinion in Britain on the nature of the univexsity as expressed in the Report of the Robbins Comittee on the future development of higher educstion. One of the nost remerkable features of this massive and infuential document is that in the whole of its six volumes only five peragraphs are devoted to a discusition of the aims and objectives of a system of higher edueation: a striking illustration of the

1. Ibid*, p.23. 
insubstantiality of the theoretical foundations upon which its recomendations rest. The chapter devoted to 'aims and principles' begins by considering whether British higher education needs to be nore systematically co-ordinated. Discussion of this point soon makes it clean that by 'higher education' the committee has in mind the entire range of what is taugt in institutions offering work at a level above that required for the Advanced level of the Ceneral Certificate of Education. Their notion of a 'system of higher education' thus covers the universities, colleges of education, colleges of advenced technology, and a considerakle number of technical and commercial colleges and schools of art. It is important to note this usage for if it is overlooksd much of the cormittee's discussion of educational aims can easily be nis-construed.

The Report identifies four principles as being essential to any 'properly balenced system' and contends thet:

... al though the extent to which each prinoiple is realized in the various types of institution will vary, yet, ideally, there is room for at least a speck of each in ell. The system as a whole must be judged deficient unless it provides adequately for all of then. I

This is a promising beginning: it avoids attempting to define the characteristics of particulor institutions and

1. Comittee on Figher Bducation, Hi gher Bducation: Report, London, H.I.S.0., 1963, para. 29. 
instead looks at the whole range of tasks which the entire system of higher learning may be required to undertake. The adoption of this approach reveals a readiness to allow for a great deal of developmental flexibility within each institution encompassed by the systen instead of alloceting particular tasks to certain sectors of the system. It also gives support to a policy of associating wi thin any one institution activities which are related in a variety of ways rather than demanding that each institution attempt to embody each of the prinoiples.

The first of these principles is: '... instruction in skills suitable to play a pert in the general division of labour'.

The second is that: '... what is taught should be taught in such a way as to promote the general powers of the mind. The aim should be to produce not mere specialists but rather cultivated men and women'. 2

The third principle is: '.. the advancement of learning $\ldots$ the seerch for truth is an essential function of institutions of higher education and the process of education is itself most vital when it partakes of the nature of discovery.

1. Ibid., para. 25.

2. Ibid., para. 26.

3. Ibid., para. 27. 
The fourth principle is: ' $\cdots$ the transmigsion of a common culture and common standards of citizenship... and that background of culture and social habit upon which a heal thy society depends?

The Report thus identifies three detivities in which universities should engage: vocational training, higher education, and the pursuit of truth. At first glance, the aims set out above would appear to indicate that the committee gave priority to the educational funotion, but other sections of the Report bring out much more clearly where the real sympathies of the committee lay. Again and agein the Report stresses the importance of viewing education as an investment in future productivity: "And, provided we always remember that the goal is not productivity as such but the good life that productivity makes possible, this mode of appraach is very helpful". ${ }^{2}$ But this disolaimer carries lit le conviction when one aiscovers that the remainder of the discussion in the section following this passage is conducted entirely in economic terms.

1. Ibid., para. 28.

2. Tbid, para. 621.

3. That the recent interest in educational matters displayed by some economists has not been an al together happy development can be inferred from the crudities of the following:

"Apart from electronics and natural gas, higher education has probably expanded faster than any other major industry in the $1960 \mathrm{~s}^{\prime \prime}$. R. Iayard and J. Ting, "The Impact of Robbins', Hi gher Education Review, 1, 7-25, 1968, p.7. 
The comittee's terms of reference encouraged it to make the mistake of 1 dentifying the system of highex learning with the eystem of higher education; having made this mistake it is scarcely surprizing thet the Report fails to distingush between education and pocational training and tends to use these terms synonomously. By "higher learning" I mean such ectivities as research, scholership and professional training which demand intellectual effort of a high order but which exe clearly distinguishable from what is involved in providing an educational programe. We certainly need institutions within which such activities may flourish but it is highly misleading to refer to them as conatituting 'the syetem of higher educetion'. A major weakness of the Report is its fallure to make distinetions of this kind, with the result that it has lent its very considerable authority to a most dangerous misconception: that of supposing that by providing for professional training we have 20so facto provided for education. Throughout the Report there are references to the economic usefulness of education and to the urgent need for more 'trained manpower'. The consequences of the recomendations to expand the provision of higher education axe concelved entirely in economic terns: - For the production of trained manpower is like the protuction of long-lived capitel goods: even after output 
has ceased to $x 1$ se a constant llow of new graduates will for many years mean a net adition to the total stock'. ${ }^{1}$ The reader of such passages has some difficulty in remembering that the comnittee was not a group of company directors preparing a report for shareholders on the 3,ong-term prospects of a lorge commercial venture; yet they are typical of the tone of the Report as a whole and provide scant evidence of any awareness of, or concern for, educational issues and the qualities of life which education seeks to promote. This pervasive and disturbing lack of sensitivity to such issues is particularly evident in the Report's assessment of the future demand for higher education where it remarks of its recomendations for expansion: How does so substantial an increase fit in with our conception of future needs? If this proportion of the population is to receive higher education, what assurance is there that there will be a need for their services? ? $^{2}$ This is followed by further discussion of the difficulties involved in making accurate

1. Op. cit., para. 182.

2. Op. oit., para. 184. The Report was speculating about British society in the year 2025, and it is amusing to note that the same assumption (but made with reference to a stoneage culture!) was made by the Governor of Papua in 1928: 'It would be unwise to give the Papuan a first class education unless we can also provide him with the opportunity to use it'. Quoted in 0. White, Parliament of a Thousand Tribes, London, Heinemann, 1965, 1.80. 
estimates of future manpowex needs and the risk of overproducing people with special skills, and sandwiched in this material is another disclaimer: "We should be very sorry, however, if [this] were to give the impression that in our view there is nothing to be said about the need for educated people in a modern comminity'. Yet nothing further is said on this, and the repetition of the word 'need' only serves to reinforce the suspicion that even in such references as this the comittee was thinicing about the requirements of the economy rather then viewing education as being of value to an individual in quite a different sense. The Report's coneern for the problem of whether future graduates will be able to find suitable employment reveals the extent to which vocational training and higher education have become confused. It is perfectly sensible to think of the provision of vocational training in terms of the likely future demand for lawyers, engineers, doctors, and so on, but it is utterly preposterous to attempt to predict the number of educated people our society is likely to need and to worry about the "risk" of having too many educated citizens.

What, then, are universities for? That are their defining characteristics as social institutions? An

1. Robbins Report, para. 192. 
examination of the recent literature has revealed five distinet functions of universities: scholarship, research, oultural maintenance and criticism, vocational training, higher education. Bach of these now requires closer examination in order to determine what each involves, the grounds on which they are justified, and the extent to which they are compatible within the framework of a single institution. Full consideration of the nature of higher edueation and vocational training will be deferred until the next chapter. The University and the Pursuit of Mruth

There is a very powerful. tradition of thought concerning the functions of the universities which associates them with activities concerned with the extension of knowledge end understanding, the disinterested pursuit of truth, the search for knowledge for its own sake. The conception of the university as a community of scholars obviously relies heavily upon the doctrine of mknowledge for its om sake" and it is therefore of the first importance to understand what this doctrine amounts to and to evaluate the arguments which can be offered in its support. Lord Robbins makes the point that our civilization is increasingly dependent upon advances in knowledge made in universities in order to sustain technical and social advance, but he also acknowledges that the universities make other contributions to the quelity of 11 fe. 
In some sense which it is difficult exactly to define, but which it is easy enough to recognize, the activities which they foster are activities which most of us would regard as good in themselves. To attempt to understand the world, to contemplate and to analyse its values -- these are activities which, even if they were never associated with practical advantage, would still lend meaning and dignity to life on this planet. 1

What is involved in claiming that something is 'worthwhile in itself' or 'good in itself' or 'valuable for its own sake'? To say that something is worthwhile in itself is not necessarily to deny that it lacks extrinsic value but rather to assert its cepacity to yield satisfactions which do not derive their value simply from being means to ends. Many people take hot baths simply because they find that immersing themselves in hot water is a pleasurable experience. By contrast, others might find the taking of hot baths disagreeable yet endure it because they believe that it will lead to better heal th or spiritual enlightenment, both of these being states which they value.

But activities, states and experiences which are worthwhile in themselves clearly need to be tried before they can be enjoyed since we cannot prediot those which we will find agreeable. Since even such simple enjoyments as hot baths and the flavours of particular foods can be 'acquired' over a period of time after repeated experinent 1. Iord Robbins, The University in the Modern Morld, London, Macmilian, $1966, \mathrm{p} .5$. 
this seems rnuch more likely to be true of highly complex satisfections of the kind associated with the study of 1iterature, mathematios and history. An important part of a teacher's task thus consists in saying 'This is good: try it', and he is always faced with the problem of persuading young people to persevere with activities which they may find initially uncongenial in order to bring them to the point where the worthwhileness of what they are doing becomes apparent to them. He also has to accept that this stage may never be reached with particulax individuals. I But when this heppens we do not conclude that the activity concerned is not worthwhile after all but that the educational process has been unsuccessful.? But what if the learner

1. Education as an enterprise could not get going however without some basic assumption similar to what Miss Loring calls '... certain universal besic tastes in experience'. 1.M. Loring, Lwo Kinds of Velues, London, Routledge, 1966, p.19. 2. Perhaps we should draw other conclusions, or at least consider seriously that there might be others to be drawn. It is not altogether eynical to admit that our present educational efforts largely fall to interest people in theoretical pursuits: most of the population evince almost no interest in the kinds of things that they were taught at school and make haste to spend many of their leisure hours in ways which their former teachers would deplore. This should lead us to reexamine, in a quite radical fashion, the entire educational programme rather than to campaign for an extension of school Iife so as to increase the proviaion of 'more of the same'in the hope that this will result in more success stories. It seems that most people, including many graduates, simply do not want to devote their time to the typical activities to be found in schools and universities. It may be that educators, imprisoned in their own interests and attitudes, are rendered incapable of acknowledging the possibility of value inhering in many activities which currently find no place in the standard academic curriculum. 
concludes thet whet he is studying is not yielding the kind of satisfactions which would make it worthwhile for him to persist with his studies? Could he then admit that al though it was not worthwhile for him it covld still be worthwhile for others? He might say, for example, II have tried reading a great many novels but find thet there is nothing in this for me, but since many people do enjoy reading novels you would be mell-advised to try it since you may find that you like it', This would be rather like saying, 'I have tried lobster and it is not to my taste; but it might be to yours, so try it and see'.

It might be objected that when we say that an activity is worthwhile we are malring more than the empirical claim thet it provides satisfaction for some people even if not for ourselves, for unless we have standards by which activities are appraised with respect to their worthwhileness we shall be obliged to allow thet any activity is worthwhile if somebody derives enjoyment from it. But these standards vary with respect to places, times and persons. Ily own standards of worthwhileness are not shared by a greet many other people and they differ markedly from those that I entertained twenty years ago; ordinarily this does not lead to any dificulties since I could not, in general, justify trying to persuade others to adopt ny own standards even though I. mey well deplore some of those which they have. 
In en educational context, however, I am necessarily engaged in attempting to develop in children a comitment to what I consider to be worthwhile - anjess I am prepared to teach anything just for the sake of the salary or a quiet life. And, in the end, I can only justify this in terms of my own desires, interests and beliefss it is the fact that I find certein activities woxthwhile that lesds me to encourage children to seek enjoyment in them. Insofar as what goes on in educetionsl institutions is viewed in terms of intrinsic velues then its justification must pinally rest upon the desire of teachers to lead others to share their om conception of the good life. ${ }^{1}$

Our concept of 'morthwhileness' is bound up wi th two criterias moral objectionableness and the general character of the activity. The first operates negatively to rule out such activities as torturing, bank-robbing, forging currency, and so on. The second is connected with the complexity of the activity, with the degree of challenge which it presents to the intellectual ox physical powers of the egent and thus rules out activities which are so undemending that it becomes highly implausible to suppose

1. Ignoring, for the moment, R.S. Peters' transcendental. deduction of theoretical curriculum activities in his Bthics and Educetion, Londion, Allen \& Unwin, 1966, pp. $157 \mathrm{ff}$. 
that they have reasons for doing them built into them. I It is to this criterion that we appeal when choosing between chess and bingo, gerdening and paper-tearing, trying to solve a philosophical problem and watching a quiz on television. Sensetions are not activities and we would not describe the taste of lobster as being 'worthwhile'. Whether or not people find certain sensations pleasurable is entirely a question of taste: a factual metter without nometive implications. But to claim that an activity is worthwhile is to appeal to stenderds, to give reasons for engeging in it and to admit that these reasons carry weight. There are an enormous number of worthwhile activities and we are free to choose among them according to inclination, but it is not the fact of our inclination and choice whichconfers worthwhileness upon a particular activity since we can imagine activities which nobody felt inclined to engage in Jet which we would be willing to describe as being worthwile: But it would be impossible to make any sense of this unless such activities shared certain cheracteristics with those which are in fact engaged in by many people. If someone said that a particular gane was worth playing but that he had no

1. An example might be the careful but pointless tearing up of strips of paper by the Irishnan in Pinter's play The Birthdey Party. 
Inclination to play it, we would be justifled in inferring that the game in question shared many charactexistics with the games which he did in fact choose to play. After all, an individual cen only engage in or watch one game of soccer on a given Saturday afternoon. And even if it turned out that a particular game was not being played at all. we could not conclude that nobody thought it worth playing: they may have had many other things to do. Because an activity is thought by rae to be worthwhile it does not follow that I must engage in it, or that if I did I would enjoy doing so. There is nothing od in my confessing that al though listening to music or reading novels yields no satisfactions to me I nevertheless believe them to be worthwhile and thus feel. able to comend them to others. But it would be very odd indeed for me to say this yet never engage in any activities which share a similar character with those which I find no inclination to pursue. It would be odd because to elaim that some things are in general worth doing comits me to doing at least some of them for at least some of the time given that I have opportunities to do so. If someone tells us that his idea of worthwhile games covered such examples as bridge, chess, golf and soccer, we could form a fairly clear ides of what he means by 'worthwhile'. But if we then discover that he spends all his spare-time playing bingo we would be forced to conclude that he does not really 
understand what 'worthwile' means sinoelhis actions imply that whenever he is afforded an opportinity to engage in gene-playing his choices are nade in the light of criteria very different from those suggested by his initiel. indication of what, in general, he considered to be worthwhile.

So to say of an activity that it is worthwhile in itself is to comit oneself to engaging in the class of activities of which this one is a member when suitabie occasions for engagenent present thenselves. In this respect at least, the word 'worthwhile' belongs to the class of value judgnents which when used with commendatory force entail imperatives. ${ }^{1}$ thus the man mentioned in the exetaple above who chose to spend his time pleying bingo would be acting in a way which was inconsistent with his proclained beliefs.

\section{Another feature of ' worthwhile when it is used} in contexts where instrumentel. velues are ruled out, is that It implies factual claims regarding the nature of the activities to which it is applied. We constaer certain types of activity to be worthwhile in themselves because we helieve them to possess characteristios which appeal to our interests and are productive of satisfactions which we in

1. Pox an analysis of value judgments along these lines see: R.Il. Hare, the Janguage of Uorals, Oxford, Clarendon Press, 1952, especisl1y p.168. 
general desire to obtain. ${ }^{1}$ If a particular activity could be shown to lack these features then this fact would lead us to deny that it was worthwhile. Thus the ascription of 'worthwhileness' to an activity implies both an internal and an external reference through which the activity in question is related to an individual's interests and pleasures as well as to a factual description of the general class of activities of which it is alleged to be a member. If I claim that an activity is worthwile 'for its own sake', then I am saying that, for me at any rate, engagement in it gives me pleasure and satisfaction of a kind distinguishable from that associated with certain sensations: the activity meshes with my interests in such a way as to lead me, other things being equal, to engage in it. Ascriptions of worthwhileness are thus doubly informative: they reveal something of the person who makes them and they describe, in a fairly general way, certain features of the activity to which they are directed. But to be meaningful they clearly involve a context of shared interests and choices in which

1. It is important to note that there is a sense in which children - and anyone else for that matter -- cannot display such interests because they are di mply unaware of the potentialities of subjects and activities which they have yet to encounter. One of the central and most difficult tasks of teachers is to introduce these new subjects in such a way that their potentialities are made manifest. 
many people can participate. ${ }^{1}$

I shall attempt to sum this up by beginning again with some fresh examples. Suppose that I am tending my flower garden and you ask me why I am gardening. I could reply that I sell the flowers in order to make money, or that I do not wish the neighbours to think that I am lazy, or that I need the exercize. If reasons of this sort provide the sole justification for my working in the garden then it is clearly an instrumental activity which I engage in solely in order to secure some further end. This seems unproblematical. But suppose that I reply: Oh, I just enjoy doing it', or 'Gardening interests me and gives me a great deal of pleasure'. I would then be saying that gardening is something which I do 'simply for its own sake', and that I have no other reasons for doing it. If I offer this second type of justification and you press your demands for reasons then there is little more for me to do beyond repeating myself: 'I tend the garden because I like gardening, I en joy it - you know what it is like to do things for this kind of reason'. Even with actions undertaken for an instrumental

1. A similar point has been made by Philippa Foot: 'Quite generally the reason why someone choosing an A may "be expected" to choose good A's rather than bad A's is that our criteria of goodness for any class of things are related to certain interests that someone or other has in those things. When someone shares these interests he will have reasons to choose the good A's: otherwise not'. Philippa Foot (ed), Theories of Ethics, London, Oxford University Press, 1967, p.9. 
purpose the line of explanation and justification has to end somewhere, as Hume clearly showed:

Ask a man why he uses exercise; he will answer, because he desires to keep his health. If you then enquire, why he desires heal th, he will readily reply, because sickdessis painful. If you push your enquiries farther, and can ever give any. This is an uItimate end, and is never referred to any other object. 1

With intrinsically valuable activities the giving of reasons for actions comes to a full-stop much earlier because we simply cannot understand what is in question when we are chellenged to justify pursuing our interests, for they would not be our interests unless we pursued them whenever suitable opportunities presented themselves. We might well find the ways in which some people choose to spend their time very puzzling indeed, but what they do would still be intelligible if it were undertaken in pursuit of genuine interests, that would be unintelligible would be a case in which the agent, while disclaiming any extrirsic value in the activity, admitted to finding it boring or disagreeable since this would normally lead us to expect and to seek an explanation which links the activity to values and purposes lying outside itself.

I shall now consider two questions which might be asked regarding what has been said so far about the

1. Ibid., quoted on $\mathrm{p} \cdot 98$. 
distinction between intringically and extrinsically valuable activities. Does the distinetion rest solely upon differences in the rinds of reasons which are offered for engaging in an activity, or are there also likely to be important differences between the actual activities in each case? This also involves asking whether it is possible to characterize an action independently of the purposes of the agent and what he conceives himself to be doing.

It seems doubtful whether there need be any difference between an activity pursued for its own sake and one which is engaged in to secure some further end. A professionel stamp valuer who is also a philatelist does the same things when he assesses the worth of his own collection as he does when he estimates the value of that of a client. He may even enjoy doing both, although this is only a required feature of what he does as a hobbyist. What needs to be shown is that there would be differences in what is learnt in these two cases; that is to sey, if a man were being trained to be a valuer would he go through different procedures (and perhaps learn some different things) from those involved in leaming to value as part of a hobby? Iven if there were no differences in the achievements in each case could we still look for differences at the task level?

Consider the example of a group of enthusiastic 
amateurs who run a previously defunct branch railway in their spare time simply for the pleasure which they get from the sctivity. What they actually do need be no different from what was done when the line was being operated by professional railwaymen. Fuxther, the professionals may have been just as interested in their work and have dexived as much satisfaction from it as do the amateurs. In such a case there need be no differences between the achievements of each group. But what about their taslrs as learners? It might be argued that the training given to apprentice railwaymen is determined by the character of their future work and they will be taught only what they will need to know in order to be able to do their job effectively. With the keen but ignorant anateurs, however, the content of what they learn is determined by the range of their interests rather than the nature of the achievements required to run the railway. They might thus be taught the same skills and knowledge together with a good deal of additional knowledge concerning, sey, social, economic and engineering history.

1. See: L.T.C. Rolt, Railmay Adventure, London, Constable, 1953. 
It could also be argued that in a case such as this the achievements are not identical: the railwaymen do only what is required of them in order to earn their pay, whereas the amateurs do as much as they can in pursuit of their interests. 'Professional' people are supposed, according to the folklore, to be in the happy position of being able to enjoy their work while other people simply earn a living, ${ }^{1}$ the suggestion being that instead of downing tools at five o'clock the professional man will finish the job in hand because his worls is not defined by the requirements of earning a living but is co-extensive with his 'spare-time' interests. I doubt whether there is very much in this: experience suggests that craftsmen, and even labourers and unskilled people, are just as cepable of going far beyond what is implied by 'the nine to five' attitude as are teachers, lawyers and doctors. Most craftsmen have a strong loyalty to the standards of quality and completeness which are built into their conception of exerciging their craft and this will often lead them to do much more than is

1. Compare Graham Wallas' remarks about Civil Service selection of graduates in classios and mathematics for complex administrative work: 'The able first-class clerk, even though he does his officiel work conscientiously, may develop his main intellectual interests quite apart from that work... and during the working day remain a gifted enateur.' Men and Ideas, London, Allen \& Unwin, 1940, p.182. Compare al so the remarks of a Hollywood film director: 'Isn't it extraordinary that Fox should pay me these huge sums of money for making pictures? If they only knew, I would do it 211 for nothing - or pay them. Making pictures is my life'. D. Young, Mry Anything Twice, Londan, Hamilton, 1963, quoted on p.355. 
required just to hold down a job in ordex to seoure the extrinsic reward of peyment. ${ }^{1}$ this is what makes it possible for some people, and not just 'professional people', to become so absorbed in their work that it no longer makes sense to speak of them engaging in spare-time activities which are quite distinct from its their work is also their hobby.

Much of the discussion, including some of my own, of the intrinsic/extrinsic value distinotion is conducted on the assumption that different justifications for an action or activity can be offered wi thout in any way affecting the description of the action. Is this assumption warranted? Suppose the driver of a car extends an arm through the window: an observer can only construe this movement as a signelling action if he assumes that the driver intends it as an indication that he is about to change the direction of travel of his vehicle. But the driver in question may be intending a variety of other things: he may wish to test the air temperature, or to demonstrate to a passenger how a particular signal is made, or to cool his sweaty palm, or be gesturing in support of a conversational point, or be brushing a wasp away from his face. The arm movement may

1. For an interesting account of the involverent of a craftsman in his work: see: S. Nurphy, Stone Mad, Iondon, Routledge, 1967. 
even be quite unintentional, a mere nervous twiteh. But it can only be correctly interpreted as a signal, that is, as an action of a particular type, if it is intended to be such by the agent. In other words, it is not possible to characterize actions wi thout reference to their point and purpose and in order to do this it is usually necessary to place them in a context $x$ ather than treat them simply as bodily movements.

This is also true of activities. Consider the example of a man mowing a lawn. If he is doing this simply for the exercize then he may well continue to push the mower across the grass long after the grass ceases to be long enough to be sliced by the blades of the mower. Or he may continue to push the machine simply in order to impress the neighbours with his zest for suburban tidiness. But then what he does could no longer be characterized as 'lawnmowing', even though, to the casual observer, it may look very much litre it. Lawn-mowing consists in more than certain bodily movements, Or consider someone who clains that he plays badminton simply for the salke of the exeroize: all he is concerned with is vigorous bodily movement, Te would not be willing to desoribe his activity as 'playing badminton'

1. Cfo. Mittgenstein's remarks 'An intention is embedded in its situation, in human customs and ingtitutions'. Philosophical Investigations, Oxford, Blackwell, 1953, para. 337. 
unless it satisfied criteria over and above those required for what he does to merit the description 'physical exercize'. What he does woula need to conform to the rules of the game and be done in order to conform to the rules; he would also give point to his movements by making then in the light of what he gees to be required in order to win the game. Neither of these conditions are demended of bodily mov ements intended simply to obtein exercize of the limbs, and if the man in this example simply rushed about the court in a vigorous but random manner this would not rate as 'playing badminton' whatever reason he gave for his movenents. This suggests that the intrinsic/extrinsic value distinction cannot rest solely upon the agent's view of the value of what he is doing; for if he claims, as in this example, to be concerned only with physical exercize then almost any vigorous movements would be consistent with his intention and we would have no justification for describing his activity as 'playing bedninton'.

This leads readily into the other issue which needs to be treated here. It could be objected that this distinction, even supposing that it can be sharply made, is of very little value since those examples to which it can be unambiguously applied are only trivially interesting. Aetivities which we take et 211 seriously almost always 
Anvolve both intrinsic and extrinsic values. The taking of hot baths and the ten minute work-out in the gymasium can scarcely be claimed to lie close to what is of central concern in our lives and experience. When we engage in sporting activities we promote our health and satisfy our interests at the same time. Hore importantid, the jobs that we do (or would wish to do) are such that they both engage our interest and earn us a living. In practice, it might be argued, both values are usually to be found in elmost every thing that we do that carries any meaning for us. If I cane into a fortune I might well decide to give up my job, but I have other reasons for doing what I presently do over and above eaming a living by it -- and these are also likely to be a very mixed bag of reasons which fall on both sides of the distinction. But even if it were not in general true that most of our time is spent in activities which are justified by appeal to both types of value it would be mistaken to suppose that to justify what one does solely in terms of its intrinsic value puts an end to further argument. For we can always ask whether there are not other things to which our time and energies should be devoted - activities which are not encompassed by doing whatever happens to interest us for its own sake. This question is particulerly pertinent to what goes on in the universities where the pursuit of knowledge is frequently justified in terms of its intrinsic 
value.

\section{For the sake of argument I shall assume that}

the intrinsic/extrinsic value distinction can be applied to activities in universities which are concerned with the extension of knowledge so that the case for and against the doctrine of 'lenowledge for its own sake' can be examined. This doctrine amounts to the claim that the pursuit of knowledge may be undertaken for the enjoyment of the increased understending which it yields and for no other reason than to satisfy what Veblen called 'idze curiosity'. This view of scholarly activity has a long lineage and is often to be found in writings about the purposes of the universities. It is clearly exemplified in a letter which Professor Henslow wrote to Charles Derwin in 1848 in which he asserted that: ... however delightful any scientific pursuit may be, yet if it shall. be wholly unapplied it is of no more use than building castles in the aim'. In his reply, Darwin allowed that scientific inquiries often turned out to have useful. applications but added:

For myself I would, however, take higher ground, for I believe there exists, and I feel within me, an instinct for truth; or knowledge or discovery, or something the same nature as the instinct for virtue, and that our having such an instinet is 
reason enough for scientiflc researches wi thout any practical results ever ensuing from them.l

But knowledge may also be sought for its instrumental value, as a tool to serve other purposes than the desire to satisfy our curiosity. Knowledge of the first type enables us to understand the world, whereas that of the second enables us to change 1t. It will be in keeping with common usage to call the activity which produces intrinsically valuable knowledge 'pure research' and that which results in instrumentelly valuable lmowledge 'applied research'.

Although these activities are distinguishable in that they at least have different purposes it would be misleading to suggest that they must necessarily result in non-overlapping bodies of knowledge. A man might study the biochemistry of cell reproduction simply for its intrincic interest of in order to discover a cure for cancer. The knowledge produced in each case could well be the same. But this would not in general be so for the difference in purpose would probably attract the pure and applied. researcher to different types of problems and lead them to generate distinct bodies of knowledge as a result of the

1. Quoted by Hilda Himmelfarb in the correspondence columns of the listener, 23 Narch 1967, p.401. 
ways in which they conceived what they were doing. Their methods of developing an attack upon problems would also be likely to differ: regardless of their intrinsic interest some lines of inquiry would be ignored by the applied researcher because he doubted their relevance as routes to his goal. 1 The pure researcher, by contrast, works under no such restriction: he is free to follow wherever his curiosity and the 'inner logic' of his inquiry may lead him. An analagous case would be that of a teacher who is concexned only that his pupils achieve success in examinations; such a limited concern would probably lead him to tum aside some of the questions asked by his pupils on the ground that they would not lead to answers which would be useful in achieving his object: We cannot go into that because it has nothing to do with the examination'. But a teacher who conceives his task as being that of extending his pupils' understanding would encourage them to raise and pursue questions which arose out

1. After the war, Zuckerman asked oneof the direotors of the Ilanhattan Project if, given the same resources, the cure for cancer could be found. "Yes", came the reply, "provided I could stop you scientists wasting time on the things which interest you" '. S. Zucicerman, Scientists and War, London, Hamish Hamilton, 1966, p. ix. 
of their curiosity and desire for knowledge. ${ }^{2}$

In societies where the pursuit of learning is given a high intrinsic value extensive bodies of knowledge have been created resulting from the development of techniques for answering questions posed by our curiosity about the nature of the world. Other societies, such as those to be found in New Guinea, for example, remain primitive in this respect for al though their members may be intensely curious about all manner of things they have not yet succeeded in producing the conceptual and methodological apparatus which enebles curiosity to move forward into understanding. ${ }^{2}$ To introduce children to these methods and concepts is often taken to be one of the basic tasks of education.

That arguments can be offered for meking provision for pure research in the universities? Unfortunately, although many authors identify this äs being one of the distinguishing features of a university they rarely attempt anything by way of detailed justification.

1. During a recent broadcast dealing with the scientific lectures provided for children by the Royal Institution of Great Britain one of the people responsible for orgenizing them remarked that the purpose of the lectures was not educational but rather to develop an interest in science! 2. It would be noxe accurate to say that such people have 'an undergtanding' but that it is often mistaken, false or partial. 
Mitchell speaks of '.. an ideal of di sinterested inquiry which is valued by a civilized society (and helps to make it civilized).... I But he seys nothing further about 1 t, and would presunably not think it any less valuable if most members of society turned out not to value 1 t. Lord Robbins simply asserts that most of us regard pure research as being good in itself.? The Robbins Report says almost nothing on this isoue beyond asserting that the search for knowledge is an essential function of universities:

It would be untrue to suggest that the advancement of knowledge hes been or ever will be wholly dependent on universities and other institutions of higher education. But the world, not higher eaucation alone, will suffer if ever they cease to regard it es one of their mein functions.3

\section{Clark Kerr's defence of the 'multiversity' is}

built almost entirely sround the view that knowledge mus t be instrumenteliy valuable, but where he does make a pessing reference to pure research he appears to assume thet it requires no justification:

The ends are already given -- the preservation of the eternel truths, the exeation of new knowledge, the improvement of service wherever truth and lmowledge of high order may serve the needs of man. The ends are there; the means must be ever improved in a competitive dynamic environment.

1. Mitchell, 100, oit.

2. Lord Robbing, loc. eit.

3. Robbins Report, op. cit, para. 27.

4. G. Kerr, The Uses of the University, Cambridge, llass, Harvard University Press, 1963, p.v. 
Sir John Fulton, in discussing the nature of the relationship between the university and society, contrasts what he calls 'the Noxth Ameriean view' wi th:

... the view that in the last resort the scholar is 2 man apart and -- subject to his acceptance of the high responsibility he bears -- that he ought to be so .... It is his buginess and his duty to attract young people in sufficient numbers from each agegroup to concern themselves with his perspectives, his time-scale, his probing beyond the appearance of things to theix ultimate nature and the laws of their behaviour. 1

Fulton is clearly concerned here with pure research but he does not offer any justification for it as an activity. This is typical of the literature relating to the univergities: one scans it in vain for arguments purporting to support the doctrine of 'knowledge for its own sake'.

I have been able to find only one serious attempt to develop a case for pure research in the university: A. . Griffiths' paper entitled 'A Deduction of Universities'. " After giving an account of intringicelly valuable theoretical activities ${ }^{3}$ in terms of the intellectual challenge which they offer, their

1. J.S. Tulton, 'New Universities in Derspective', in D. Daiches (ed), The Idea of a llew University, London, Deutsch, $1964, \mathrm{pp} \cdot 14-1 \overline{5}$.

2. A.P. Griffiths, 'A Deduction of Universities', in R.D. Archambeult (ed), Philosophicel. Analysis and Bducstion, London, Routledge, 1965.

3. This is developed along similar lines to R.S. Peters' justification of worthwhile activities in his Ethics and Education, 10c. cit. 
public and universal character and their capacity to develop a love for them in those who pursue them, Griffiths claims that the environment most suited to their pursuit has traditionally been provided by universities. He then points out that a centre of learning, conceived of in this way, demands its keep from the community in which it exists and the commity is entitled to asts why it should provide the resources which the pursuit of learning requires when the enjoyment of this activity is only available to a few. Griffiths' reply is that:

... we must not too quickly reject the value and importance of selfish ectivities. It is only a kind of lunatic puritanism that would condemn all selfish activities. If an activity is supposed to have value only in its contribution to the mellbeing of others, then value can reside only in effects, only in what is suffered and not in what is done. This is to ignore the value of activities as such al together.

This point is well-taken, for some of the critics of 'learning for its own sake' fall to appreciate that it is incumbent upon them to produce argunents for making a special case against its place in universities since they presumably do not wish to deny that there are any intrinsically valuable activities. It is worth looking at some standard criticisms of pure research in the universities in order to determine whether such a special case has jet

1. Op. cit., p.194. 
been made out.

Perhaps the most basic criticism stems from an awareness of the vast number of urgent problems which face manind and which demand applied research for their solution: disease, overpopulation, wi despread undernourishment, inadequate housing conditions, the poverty which millions of people are obliged to endure, and the inedequate life-style which all this implies for a large proportion of the world's population. Faced with such facts as these pure research can be made to appear a trivial and almost shamefully wasteful activity. Should we not be dixecting all of the intellectual and financial resources we can muster towards the resolution of such momentous issues as these rather than fxittering some of them away in the selfish pursuit of leaming for its own seke? This line of argument undeniably has a strong appeal to anyone with a nodicum of social conscience, but there are three replies to be made to it. It is sonetimes claimed that pure research, especially in science and technology, often (but unpredictably) yields knowledge which subsequently proves to be of the greatest practical value. But this is not a convincing rejoinder since there is no reason to suppose that practical issues are not best tackled head-on rather then $b y$ awaiting the by-products of the work of those who are aiming at quite different ob jectives. 
A more weighty reply might be developed by questioning the assumption upon which this case rests, namely, that our material cireumstances are so desperate that we simply cannot afford, morally and economically; to devote scarce resources to intellectual activities which have no obvious 'use'. 1 This may well be difficul to accept as far as the advanced industrial nations are concerned, al though even in these cases it could still be argued that pure research is moraliy insupportable. A much stronger case could be made out for the under-developed nations where practicel knowledge and professional skills are in very short supply. Should not the universities in these countries devote all of their resources to the solution of theix locel problems and to the training of doctors, engineers, technologists, agriculturalists, teachers and lawyers, leaving the pursuit of philosophical and historical understanding until such times as these luxuries may be

1. Griffiths is not altogether fair on this issue: 'Except that a mathematician withdraws his hands from the production Iine, he diminishes no one'. Op. cit., p.194. This may well be true, but a more worxying example would have been some of the research in, say, physics which requires extremely costly equipment for its prosecution. 
afforded? $?^{1}$ No doubt a strong case could be made for such a proposel but it would ultimately turn upon whether the good Iife' is to be seen solely in terms of the enjoyment of creature comforts, and ony discussion of this leads to the third and most important objection.

Men seek to be free of poverty, disease and heavy toil partiy because these are disagreeable in themselves and partly because they interfere with their doing what they would choose to do were they not impeded by them. There is an important sense in which we need to be able to take for granted heelth, food and shelter in order to be able to get on with those activities which interest us. It is only when such conditions are not satisfied or satisfied only to a very limited degree, that we are obliged to give first place to applied research.

Our decisions regarding the distribution of resources between intrinsically and extrinsically valuable activities pertly turn upon our attitude towards discovery.

1. Some of the new African states do in fact adopt such a policy. In a letter to The Mimes, Kwame Afreh said that: ... universities in Ghaña rely I0o per cent on the Government for their funds and that, in my opinion, the covernment was entitled to refuse financial support for a course of study which in its opinion was not relevant to the needs and aspirations of the country .... section $2(a)$ of the University of Chana Act, 1961 provides: "... in determining the subjects to be taught emphasis should be placed on those which are of special relevance to the needs and aspirations of Ghanaians, incluaing the furtherance of African unity" . The Mimes, 25 January 1968. 
If we value discovery only as a productive good then we shall be likely to support applied rather than pure research; but if we recognize the pursuit of learning as a consumptive good then it mexits at least the same amount of support as those goods which applied research aims at securing. ${ }^{l}$ Public funds are provided for the support of pure research, and the system of training and education which is a prerequisite of its pursuit, because it is appreciated by a sufficientiy large body of people that the kinds of understanding possessed by scholars can be enjoyed to varying degrees by all members of society in the same way that all can enjoy the fruits of applied research. Private patronage of the latter would be intolerable if it led only to private benefits, and if the knowledge ard understanding yielded by scholarship were to be restricted to those with the financial means to support it such a situation would be equally intolerable. Unfor tunately, the enjoyment of the pursuit of knowledge for its own sake is at present, for a

1. For the first of these doobrines see: H.G. Johnson, - Federal Support of Basic Research: Some Bconomic Issues', Hinerva, ITI, 500-514, 1965; O. Kaysen, 'Federal Support of Basic Researcht, Minerva, IV, 254-272, 1966. For a defence of the second viet see: Toulmin, the Complexity of Scientific Choice II: Culture, Overheads of Tertiary Industry" Minerve, IV, 155-169, 1966. For an examination of the assumptions underlying both positions see: S. Rottenburg, The Tarrants of Basic Research', Minerva, V, $30-38,1966$. 
variety of reasons, restricted to a very small section of the community; but the value of pure research is rarely attacked on the grounds of its inequitable availa bility.

The substance of the third rejoinder to those who attack pure research in the universities consists in challenging them to describe a form of life in which the search for truth and understanding plays no part. Put as bluntly as this, there are probably fer exitics who would wish to deny the value of scholarly activity altogether; Instead, they fall back upon the clain that a great deal of it, as currently practised, is in some sense 'irrelevant' to extending our understanding of the world. A well-known critic of the universities who adopts this position is Exic Robinson. He asserts that:

Use of the formula 'discovery of new knowledge' can, at worse, encourage trivial work - $\rightarrow$ and this is the nature of much academic research at present. One of the reasons why triviality can so easily gain the ascendency is that academics often find difficulty in establishing criteria to determine what is and what is not significant. It can be argued that these criteria are ultimately social and economic but the academic ideal forbids this. The concept of ultinate truth which pervades much of academioi sm has educational consequences which are damaging....2

1. Cotgrove, for example, in discussing the place of liberal studies in technical colleges, says:... the esteem wi th which such studies are sometines viewed would seem to derive from their role as status symbols rather than from their relevance to life in an industrial society'. S. Cotgrove, 'Mducation and Occupation', British Tournal of Sociology, XIII, 33-42, 1962, P.37.

2. B. Robinson, The New Polytechnics, London, Cornmarket Press, 1968, p.81. 
It is not 21 together clear what Robinson meand * by 'relevance' here, although there is evidence elsewhere in his book that he is not thinking in terms of criteria which are internal to scholarly activity. At one point he invokes the opinions of Sir Paul Chambers (when Chaiman of ICI) concerning the unsuitability of many graduates for employment in industry because they are alleged to be defective in the capacity to make decisions in 'real situations'. Robinson presumably means by 'relevance' the usefulness of knowledge in solving the problems of industry and comexce, but he does not produce any argurents to show that intellectual work which is not relevant in this sense is therefore without value. But it is clearly possible to make a distinction between trivial and non-trivial scholarly work without appealing to criteria which axe quite independent of the world of learning. Bach area of inquiry has its central. problems which are recognized as such by most people working in the field and it is by reference to these that the notion of 'relevance' is given substance and point rather than by the contribution which a piece of work is able to make to the problems of industrialists. Fobinson claims that the academic ideal is: 
... based on the 1 dea of knowledge in itself rather than knowledge for a puroose and this affects not only the generel direction of research but also the relevence of its findings .... The implication of the word 'research' is of discovery rather than creation .... The idea that original academio work consists of the discovery of what is there, rather than the creation of ideas to explain experience and of devices to improve it, goes far to explain, for example, the lack of attention and recognition which the academic world has given to writing ... to engineering design... to the visual arts and to music. 1

This clearly amounts to a denial of intrinsio value in the pursut of knowledge and an acceptance of a view of knowledge which perceives value only in its uses. I have earlier tried to show some of the inadequacies in such a conception of knowledge and of scholarly activity in general, but there may still be something to be said for the claim that the pursuit of knowledge should be 'socially relevant'. $\Lambda$ difficulty here is that this is an ambiguous expression which Robinson does nothing to clarify. If it is construed solely in terms of what is instrumentaliy val uable as a means to increasing the GNP or maximizing the profits of ICI then we would be forced to adnit that much of what is done by scholars is without velue, but this is a construal which needs to be established by argument rather than by dogmatic assertion. But it seens unlikely that Robinson would want to cerry his objections quite that far; we could rely on

1. Ibid., pp. 80-81. 
enother interpretetion of 'socielly relevant' which merits serious attention and diseusgion.

It could be argued that unless the pursuit of knowledge illuminates and extends our understanding of the world and our place within it, then $1 t$ is, in an importent sense, trivial and irrelevant - al though not viciously and harmfully so in the way that Robinson and some other critics of 'ivory towexism' intemporately suggest. In this senge of 'relevant', what we know and understand makes a profourid Alfference to our conception of the woxld and to the extent of oux ingight into the potentialities of human action and responsibility: it helps to create end modify both what we axe and what we perceive other people to be. There is nothing trivial about this, but neither is there any thing of obvious 'use' in it. A sense, Justified or not, that much of what currently goes on in universities is irrelevant to these central human coneerns undoubtecly lies behind a great deal of the recent student criticim of the univergitieg, This unessiness has been aptly expressed by David Craig:

The life of a university teachex in the humanities heg one peouliar tension at its heart. Fe sit here, confortable, well-equipped, paid-for, secure, and study monitind embrolied in the most acute dilemmas and surferings..... Our education - thet is, our command of the printed and graphio sources end our ability to beam oux imiginations into 811 depths and corners of human experience - faces us at close quarters with the whole manifold intense human state, while at the same time demanding, in the name of scholarly or professional objectivity, that we keep 
an antigeptic alootrege $\ldots$. The thing $\operatorname{san}^{2}$ t be done. Ither the aloofness turns into pedantry, or else It givea way to an involvement psychologiosily grueliting but wholly woxth-while becsuse it bringe into the mind of the cxttic, scholhx ox student something of the direct grapple with raw 21 ie that 1 s carried on continuouely by the axtist ox the ectivist.

There would seem to be two srounda on which the pursuit of leeming ean mext a place within the univeralty. Mrst, we ean sey thet the search for truth, knowledge and understanding $1 \mathrm{a}$ an activity which is intringically valuable, that 1 is 18 worth pursuing for 1 ts own sake on sccount of 1ts fescinstiona, chellerges and the Intelleotral set1 sfactione which it offerg. V1ewed in this way it becomes an element in a fom of life which is constäered worthwhile 1 t may even be laxgely oonstitutuve of e fom of 11 fe. This $1 \mathrm{~s}$ not to sey thet it $1 \mathrm{~g}$ a neceseary element in and worthwhile foxm of 21 fe, al though 1 t is not eacy to envisege ways of living which could be entirely gatisfying (ox satisfectory) without some element of truth-seeicing. It follows that the poseibility of engeging in this activity

1. D. Crats, 'Mecolng if Hew', The Jistener, 489-492, 17 Oetobex 1968, p.489.

2. I taice 'form of 11 fe' to mean a style or mode of living which is characterd stio of on 1 ndividuel. (or a soeial. group) to the value of whioh he is explioltiy comitted. This usage also allows ponebody's life style to be seen as conposed op a number of guch foms. witgenstedn appenrs to have meant eomething rether different by this expression:

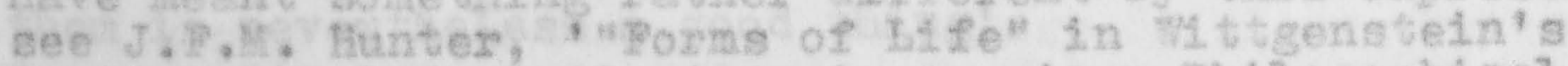

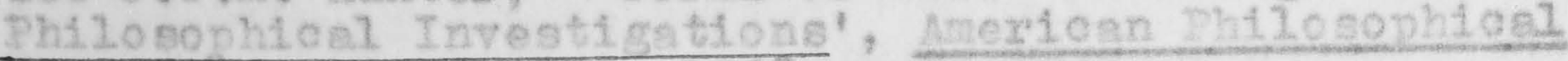
cuarterLy, V, 233-243, 1968. 
should be open to all, and It is one of the functions of education to make this a reality. It hes traditionally been a. distinguishing feature of univergities thet they have offered a suitable enviroment in which learning may be pursued: if they did not offer such on environment then we would need to ereate a new institution to provide it. This still leaves it open to eny individual, to decide that, morally (say), other activities have prior olains upon his time. It mey also be necessary at cextein times in particular places for a society to decide that until the general quality of life is improved there is no justifieation fox diverting scarce resources into the pursuit of lcnowledge for its own seke. In the end, no justification for this activity can be offered beyond commitment to a perticuler way of life: the standards by which we appraise worthwhileness in this connection embody ultimate value commitments and therefore cannot themselves be justified in terms of a further set of standaxds. It is also fruitless to appeel to extrinsic usefulness here. As Griffiths has pointed out, we must simply make our stand: There is no reason to suppose that the consequences of learning to pursue these activities will be anything other than the ability to pux sue them; but being able to pursue then is nevertheless a good thing'.

1. Op. eit., p.205. 
Secondly, the search for understanding is part of what is involved in maing sense of our experience. The knowledge which it provides engbles us to desl more effectively with problens, issues and puzzlements which seem to Iie elose to the centre of lifes it thus both constitutes and changes our view of the world and, in this sense, it is extremely relevant to everything we do, every decision we make and every experience which is open to us. ${ }^{1}$ Put in this way, it is difficult to erasp what is being demanded when someone asks for a justification for an activity of this type. Why would anyone not wish to engage in it? But this is not to say that we cannot be mistaken about which are the most important issues or about the ways in which they should be contemplated, felt and handled. So there is room here, In a way in which there is not in the first line of Justification, for disagreement over the determination both of the issues which make up the centre of what is conveniently called 'the human condition' and of the answers to the question 'Thet has this inquiry or study to to wi th life?'

1. The university should be a place of resolute and untiring pursuit of truth in matters of the highest significance. The nature of man and of the world, and its practical implications for conduct, are on any showing foremost among such matters... to ignore or gloss over them $\ldots$ is unworthy of a university'. 7. Moberly, me crisis in the Universtty, London, S.0.Mll. Press, 1949, p.93. 
The adoption of one or other of these justifications for the pursuit of knowledge will obviously have important consequences for the ways in which universities respond to the challenges to what they do as well as the manner in which their other functions are carried out.

\section{The Universi ty and Applied Research}

\section{The universities are now najor centres of}

applied research contributing towards the massive output of the 'knowledge industry' I A growing amount of their work is increasingly devoted to the production of knowledge which is of imediate use in adang to the efficienoy and wealth of the nation. Governments and private industry look to the universities to provide the knowledge required to increase productivity, build up economic strength by improving comereial competitiveness, maintain defence effectiveness through the advance of weapons technology and, in general, be an instrument of corporate material enrichment. This has not been one of the traditional functions of universities; they began to be involved in applied research only in the nineteenth century and the current heavy comitment to it

1. 'Tnowledge is now central to socis ty. It is wanted, even demanded, by more people and more institutions than ever before. The university as producex, wholeseler and retailex of knowledge cannot escape service. Knowledge, today, is for everybody's sake'. C. Terr, the Uses of the University, op. cite, p.114. 
has really only developed during the past thirty years or so. The pursuit of instrumental knowledge produces no special problems of definition or justification since it springs from the desire to achieve ends which are

independently justified: there is thus no need to examine it here in any detall. There is no diffieul ty in understanding how universities erme to take on this responsibility: pure and applied research require the same intellectual shills and are often undertaken by the same people. This is to be expected sinoe it is often impossible to make a sharp distinetion between the two bodies of knowledge and an interest in both practical and purely theoretical problems are commonly to be found together. It would therefore have been most odd if universities had not become centres for applied research. Difficulties arise, however, when the demands of applied research ere thought to be in conflict with the other functions of the universities. It is often said, for example, that the universities' growing responsibility for the production of instrumental knowledge is seriously threatening their role as cultural and educational centres and forcing them into an unheal thy over-dependence upon governmentel support and consequent control. There is uneasiness on the part of scholars who see their freedom and independence as being gradually eroded; students claim that 
they are being defrauded by lecturers whose sexious interests rarely extend to the classroom; the old idea of the university as a community of people united by common scholarly interests is being undermined when too many researchers are supported by defence contracts and subventions from ICI; others see a danger to the university as a centre of free speech and social oritioism if too much of its worls is determined by powerful extemal agencies. These fears are all generated by the growing involvement of the universities in applied research, but as they relate to the problems of incompatibility of function I shall defer discussion of them until later since litule of value can be seid until each function has been exrmined.

\section{The Univergity as a Centre of Cul ture}

There are many references in the literature to the function of univergities as centres of cul ture but it is not often made clear what the exercize of this function consigts in. If 'culture' is taken to refer to the lmowledge, skills and activities characteristic of a particular civilization then a university which concemed itself deeply with pure research would be ipso facto a centre of culture. Griffiths talres this position when he considers what would constitute a culturel centre: 
It would be a place where people pursue not only physics, but philosophy; not only philosophy, but music; not only music, but engineering (nobody can understand our world and be an all-round oultured man without a knowledge of the nature and problems 1 of engineering); not only engineering, but theology.

But this is not quite what some people have in mind when they speal of the cultural role of the universities; they want scholarly activity to be directed towards the illuminetion and resolution of social and human problems rather than be 1 ts own end. Leavis, for example, sees 2

'culture' in terms of a tradition of thought and feeling which exercizes a criticel function in relation to society at large:

The universities are recognized symbols of cultural tredition - of culturel tredition still conceived as a directing force, representing a wisdom older than modern eivilization and having an authority that should check and control the blind drive onward of melexisl and mechanical development, with its human conseauences. 3

\section{Leavis's factual cleim that the universities}

1. A.P. Griffiths, 'A Deduction of Universities', op. cit., p.198.

2. For some criticisms of the notion of 'tradition' which is usually employed in educational theory see: H. Weisberg, 'Tradition and the Traditionalist', in I. Scheffler (ed), Philosophy and Education, (second edition), Boston, Allyn \&: Bacon, 1966.

3. F.R. Leavis, Education and the University, op. cit., p.16. 
are recognized as sources of wisdom and authority for what are essentially questions of value is highly arguable; and his belief that the 'traditional culture' is necessarily the property of an elite minority is itself a minority view. But what needs to be noticed is that he sees the traditional scholarly activities of the universities as being fundamentally normative in that they can be used to determine and to help to maintrin values which axe alleged to be threatened in a society which is increasingly shaped by industrial and technological development. The inspiration which he derives from the worls of D.H. Lawrence and George Sturt with their myth of a former rural society destroyed by the evils of industrialism leads Leavis to a position which is both grossly over-stated and distressingly elitist. ${ }^{1}$ It also leads him to view the universities as embattled remants defending a fast-vanishing way of life against the enoroachments of modernity: the battle seems impossible to win jet it cen never be entirely. 1ost as long as the universities (or rather, at least one 'anoient Inglish university'2)

1. Reymond williems has an apt coment here: 'The concept of a cultivated minority, set over ageinst a "decreated" mass, tends, in its assertion, to a domeging arrogance and scepticism. The concept of a wholly orgenic and satisfying past, to be set against a disintegrated and dissatisfying present, tends in its neglect of history to a denial of real social experience'. Culture ena society 1780-1950, op. cito, p. 263 .

2. Leavis, op. cit., p.19. 
hold out. 1 this view of the university as the last bastion of an enlightened and eultivated minority would be of little interest: $m$ is $x_{\text {the }}$ fact that it is associated with a view of scholerly activity and knowledge which sees it as belng dixectly and intinately concerned with contemporary social issues: Leavis, for example, 1s deeply troubled by the thuman conseguences' of indugtrialization. His remedies may not carsy conviction but his concem that knowledge and understanding should malce a difference to the way we feel and act, both privately and socially, ploces his idea of the university close to the centre of contemporery controversy about higher education.

This is not to sey that meny of those who are currently concerned with the universities' fellure to involve themselves with social issues wovld be in sympathy with Leavis's claims for the pre-eminence of the literery sensibility and the restriction of this to a handful of people. Herbert Mercuse, for example, would scarcely be

1. This is strongly reminiscent of another of treavis's sources, Natthew Amold, especiel.1. his elegiac deseription of Oxford as the home of lost causes: ' We have not won our political betles, we have not carried our main points, we have not stopped our adversaries' edvance, we have not marched victoriously with the modern world; but we have told silently upon the mind of the country, we have prepared currents of feeling which sap our edverseries' position when it seeris gained, we have kept up oux communications with the future', Culture and Anerchy, (edited by J. Dover Wilson), Cambridge, the University Iress, 134, pp. $61-62$ 
likely to support Leavis's retro spectionism but he shares the belief that the universities should be comitted to the defenes of extain values and that their members should act accordinglys There is one general comminent which I think every university should heve, namely the comitment to values which protect and promote humanty, peace, justice'. 'Thts is phrased in such general terms that scarcely anjone would be likely to dissent from 1 t: only when 1 ts 1 mplications are spelled out in detail is such a comitment liable to be seen as a challenge by defenders of 'pure inguiry' and elements in society which do not welcome the questioning of their value assuriptions and the suggestion that these should perhaps be changed.

This leads easily to the view of the university as a centre of culture in the sense of an institution capable of airecting a steady stream of criticism at the values and life-styles to be found in its parent society. This oritical cultural function of the university arises naturally from a conception of scholarly activity as being a search for meaning and truth in understanding ell aspects of human experience and using this understanding to shape future experience. The pursuit of fruth is thus not to be

1. H, Naxcuse, "wrhe Fether of Student Rebelition"?" The Listener, 498-499, 17 october 1968, p.499. 
construed as an essentisily spectatoxirl activity (if that may be allowed) atmed at improving our descriptions of reality but cather as an attenpt to matce use of this knowLedge as a guide to ways in which expexience may be changed and explored in mote valuable directions. Those who believe this to be one of the functions of universities are alamed when they see evidenoe of universities aligning themselves more closely with contemporary social values and fear thet there may be a loss of: the velue of the independence of thought and expression of the universities compared with the rest of society...... 1

The univercities ere institutions which are uniquely placed to efford apportunities for social extios to speak out fearlessly on any topic which seems to them to be of consequence even though what they have to say may be extremely unpolatable to those governments, politieians, social groups and Individuals who may be the subject. of oxt ticism, It is this possibility which some people have I. II. Teston, 'Qualitby and Bquality', Higher Mducation Review, I, 77-86, 1968, 2.83.

2. The following comment on the new University of Papua and New Cuinee illustrates this point very well. "Another function the University may Increasingly adopt is that of gadily. It is common in most countries for academics to use their Ireedom and theix expextise to comment on the sooiety they are $i \mathrm{n}$ and how it conducts $1 \mathrm{ts}$ affairs .... The Adninistration here is unlikely to welcome public comaent and criticism any more than its counterparts do in Australia.' B. Roe, 'The Development of Mextiary Bancation 1n M.P.N.G.', Australian Journal of Bduoation, XI, 58-72, 1968, p.72. 
in mind when they speak of the value of the independence of universities as cultural centres. Not everyone shares this view, of course: for some this freedom of expression constitutes a threat to the stability of society and they tend to interpret the cultural function in terms of a social mirrox rather than an irritating critical gadfly. Clark Kerr, for example, asks: 'What is the justification of the modern American multiversity? History is one answer. Consistency with the surrounding society is another'. ${ }^{1}$ A less equivocal expression of this view would be: '... the university is the servant of the dominant values of the culture and not their source', ${ }^{2}$ Bven the Robbins Report spoke of the need to provide: '... that background of culture and social habit upon which a heal thy society depends'. 3 Against this, it is increasingly being said that the universities are tending to reflect social values too faithfully and failing in their responsibility to maintain a critical stance towards what goes on around them. This is often felt acutely in the United States and is sometimes vigorously expressed in student judgments on their institutions.

1. The Uses of the University, op. cit., p.45.

2. H.C. Noble, book review in Religious Education, LXII, $1968, \mathrm{p} .408$.

3. Op. ci.t, para. 28. 
The main concern of the university should not be with the publishing of books, getting money from legislators, lobbying for federal aid, wooing the rich, producing bombs and deadly bacteria. Nor should it be with passing along the morality of the midde class, nor the morality of the white man, nor even the morality of this potpourri we cell 'Testern society'.... Already, however, the parallels between the habits of the university and the babits of society are many. I have listed some; include with these: the perallels between our academic and financial systems of credit, between competition for grades and for chamber of comerce awards, between cheating and price rigging, between the statements 'attendance is a privilege, not a right' and 'we reserve the right to refuse service to anyone'. I

These are the words of an American student, but

the sentiments they express are slowly coming to be

sympathetically recognized by some of those who run the

universities as the following extract from a speech by the

Principal of a Canadian University shows:

The universities draw large numbers of questing idealistic students. Some of them ... have decided that the universities are the handmaidens of the establishment, of the business and corporate elite, not only serving the status guo but using the educative process and the university resources to clamp its grasp more tightly on us. These young people are some of them intoxicated, some of them deeply shaken, by the discovery that man and the world are mysteries. They want all the adventures of the mind in probing the mystery and of the tongue in talking about it, and they find their university too much preoccupied with the mundane, the immediate and the practical. They are potential allies for defending the citadel of the free minds. 2

1. T. Hayden, 'Student Social Action: From Liberation to Community', in D. Adelstein (ed), Teech Yourself Student Power, London, Radical Student Ailiance, 1968, p.48.

2. J. A. Corry, 'Universities' only Security is in Public Opinion', University Affairs, $\mathrm{x}, \mathbb{N o}, 1,18-19,1968,0.18$. 
A11 the time that scholarly activity is conceived in spectator terms, that is, in terms of description and explanation, then there is little likelihood of universities being centres of social and cultural criticism and the issues outlined in the above quotations would scarcely arise. But if the pursuit of knowledge is allied, in Leavis's phrase, to, 'social conscience and political will' (not to mention political action), then the universities vill be subject to pressures from a variety of outside sources. How, then, is such a function to be justified? The most obvious justification lies in showing that the freedom of thought which the pursuit of truth demands cannot be restricted to pre-determined 'safe' topics and areas: scholars must be able to follow their inquiries wherever they may lead regardless of the sectional interests of governments, the business community, or whatever. But this is only an argument in favour of unrestricted pure research when the latter is thought of in terms of description and explanation: it does not support a wider conception of research and culture which sees as part of its function the role of knowledge and understanding as a basis for both informed criticism and rational action. Justification for this view can come from two related sources: our concept of man as a being who thinks, feels and ects; and our concept 
of an educated person as b being who thinks, feels and acts in perticular and characterietio ways. I have already attempted to say something about the first of these lines of justification; the second will be approached from a variety of angles in the ohapters to follow

In this chepter five defining characteristics of a university have been fdentifled and three of then have been exaraned with a view to determining their nature and the possible grounds of their justification. The next chapter will complete the discusston of function by looking at the notions of higher education and professional training. 
CHAPTER III

\section{Hi gher Education}

The remaining functions of the universities, professional training and higher education, may conveniently be treated in juxtaposition since they comprise the teaching role of the universities and are clearly in a different category from scholarship, research and the notion of a cultural centre. The meaning and justification of professional training will be examined first, using teacher-training as an illustrative example, and then the far more complex concept of 'higher education' will be analyzed. It will then be possible to look at the five functions which have been identified in order to determine the extent to which they are compatible and mutually dependent: it is essential to be clearer about this before one can assign responsibilities to particular ingtitutions. The existing disposition of institutional responsibilities is largely the result of the historical development of institutions and partly a consequence of political decisions often made withnu reference to educational considerations. 
The University and Professional Training

Industrialized nocieties display seemingly

insatiable appetites for people who possess high-level

skills and knowledge with immediate prectical application

and utility: without an adequate supply of doctors, teachers, engineers, lawyers, designers, architects and technologists

of all kinds oux whole way of life would be greatly

impoverished. ${ }^{I}$ The 'developed, nations increasingly look to their universities to provide a flow of experts who are competent to handle the many social and technicel tasks which modern societies have created; this builds up strong pressures upon the universities to devote larger slices of their resources to professionel training and to extend the range of their commitment to such training. ${ }^{2}$ The rapidy growing demand for specielized skills and knowledge has led to a situation where it has now become an accepted element of social policy for the universities to be conceived as the

1. For example, about 850,000 engineers were employed in the United States in 1960 and 1 t is anticipated that two million will be needed by 1975. D, Bell, the Reforming of General Education, New York, Columbia University Press, 1965, 2.83.

2. 'Once in the industrially advanced woxld the commity -or the nation - that wanted more industry gave first thought to its capital supply, and how to reassure the bankers. Now it gives first thought to its educational system: how to obtain the required specialists'.J.Z. Gelbraith, 'The Role of the State', The Listener, 8 December 1966, p.843. 
major centres of the 'knowledge industry', responding to the demands of government and industry for trained personnel who are able to satisfy what are perceived to be the immediate needs of society.

There is nothing new in this association between the universities and the professions: since the middle ages the universities have been preparing students to be priests, lawyers, doctors and state functionaries. But what is new is the current extent of the association and its increasing development; this has led to uncertainty about the nature of the relationship and the principles upon which it rests. Some have argued that the universities should have nothing to do with vocationalism on the grounds that it interferes with scholarship and education; others have applauded the connection and worked for its enlargement; some have urged a compromise which will permit the universities to admit only those professions which require their practitioners to possess the kinds of knowledge and attitudes traditionally developed by a universi ty education.

Most of the literature on the universities says remarkably little about their work in relation to professional training: a large part of it is concerned with the setting-up of criteria which can be employed to make decilions regarding the admission of new areas of 
professional study. The Robbins Report speaks only of 1... Instruction in skills suitabie to play a part in the general division of labour ..... Although the Report conteins a good deal of purely desoriptive material relating to the provision of professionel training throughout the country, it says almost nothing about the nature of such training and the ways in which it might be distinguished from higher education. There appears to be only one reference to this topic and this reveals that the comittee may have had a distinction of this kind in mind even though they did not make it explicit and despite the fact that the early sections of the Report strongly suggest that they took 'higher education' to refer to all of the teaching in universities and other high-level ingtitutions. This reference occurs in a discussion of the provigions which are made outside the public sector:

It is difficult to generalise about modes of preparation, but in most cases it can be said that, sinee the exaninations are designed to maintain professional quality, the standards are severe, Criticism therefore is likely to be based much more upon lack of humanistic breadth and upon narrow technicality than upon absence of inteliectual difficulty. And we have little doubt that some of the criticism has in the past been justified. A lawyer, an $\$$ accountant or a company secretary trained in this way was not likely to be lacking in professional knowledge as compared with his counterpart who had passed

1. Robbins Report, op. cit., para. 25. 
through a university or some other ingtitution of higher education. But he was perhaps less likely to be sensitive to the general implications of his subject, and for that reason, less aware of the currents of change. 1

The main suggestion here is that the professional training offered by the universities usually manages to avoid concentrating upon nerrow technicalities by emphasizing general principles and a critical spirit, thus equipping the future practitioner with a capecity to keep his knowledge up to date and to see what he does in a broader human context. This connects with some earlier remarks in the Report which warn against the dangers of producing 'mere specialists'?

... it is the distinguishing characteristic of a healthy higher education that, even where it is coneerned with practieal techniques, it imparts them on a plane of generality that makes possible their application to many problens - to find the one in the many, the general characteristic in the collection of particulars. It is this that the 2 world of affairs demands of the world of learning.

The Report thus picks out two features of the professional training programes which are offered in universities: their emphasis upon the human context in which the student is to exercize his skills, and the use of methods of teaching which stress underlying principles and flexibility of mind when faced with the inevitable future

1. Ibid., para, 511.

2. Ibid., para. 26. 
developments within the profession. I. It is suggested that all vocational training need not neet these requirements since the Report sees the second of these features as providing a criterion '... of what institutions of higher eưcation may properly teach'. 2

Those who have accepted that the universities should make some provision for professional training have often not been willing to open the campus doors to every professional group which knocks on them, and they have attempted to justify this selectivity by demanding that the proposed course of training have some affinity with the traditional concerns of the universities. The Robbins Report, for example, discerns a criterion in the level of generality of the principles which are taught: this is an obscure point, not made any clearer by the fallure to provide

1. This should be treated as a prescxiption rather than a description of what university professional training courses actually offer: there is plenty of evidence to suggest that many existing courses do not meet these requirements. A Canadian Report on medical training, for example, claims that if major changes are made: The basic goel of the undergraduate student wovild then be to learn how to use his mind in scholarly preparation to cope with the health problems of his fellow man. The method of solving problens would take precedence over the mastery of masses of detailed knowledge of uncertain relationship to this process'. J.A. MacFarlane, et al. Medical Education in Canada, Royal Comission of Health "Services, Ottawa, Queen's Printer, 1965, p.45.

2. Robbins Report, para. 26. 
any examples. The comittee probebly had in mind a contrast between 'narrow technicality' - a concern solely with facts and routine procedures -- and having a 'broad grasp' of a professional competence. The latter would be displayed in the practitioner's ability to search economically for knowledge when required, to adapt to new procedures readily, and to 'thinls on his feet' instead of having constant recourse to an inflexible mental rule-book. I am reading this into the Report's cryptic remarks, but such an interpretation wovld be in line with most of the recent writing on professional training. The Goodenough Report on lledical Schools, for example, said that: The main emphasis should be on the inculeation of fundamental principles and methods rather than on the implanting of a mass of purely factual knowledge'. 1 The more recent HacFarlane Report refers to current developments in medical education as being indicative of a '... move from an undergraduate course that was primarily vocational to one basically oriented towards the university goal of self-discipline in critical, logical thinking'. 2

1. Report of the Inter-Departmental Committee on Medical Schools, london, H. II. S.0., 1944, p.12,

2. Maciarlane, op. cit., pp. 45-46. It is worth noting the sharp distinetion drawn in this passage between vocational training and higher education. 
This criterion is concerned with teaching methods and the contents of the syllabus, but there is another one which is related to the branches of knowledge which are currently investigated in universities. This latter criterion might be used to admit managenent studies (on the grounds that they involve the study of eoonomies, social psychology and sociology) but refuse entrence to catering or dress-making. This notion can be seen at work In the Nufiela College Report where it discusses the universities' difficulties in meeting demands for new forms of professional training:

The distinction must be drawn, as it alweys has been in good university practice, by a consideration of the content of the specialized instruction sought. If a profession wishes the study of the subjects peculiar to it to be associated with $\mathrm{a}$ study of the underlying sciences or other branches of knowledge (in which the university will already be engaged), there is a case for including it in the university's scope ....1

This Report admits that the line between professional and non-professional studies is not always clear but insists that: 'The university is, however, primerily concerned with the tasis of preparing the mind by relating the purely professional to the purely scientific element in the problems studied.'

1. The Problems Facing British Universities, Report by a Nuflield college Commitee, wondon, Oxford University Press, $1948, \mathrm{pp} .90-91$.

2. Ibid., p.91. 
The value of this as a selection oxiterion clearly depends upon the nature of the worts for which the student is being trained, Jet a deternined advocate of vocationsl stuales in universities could make a plausible case for admitting an enomous number of voeational courses which would setisfy, in sone sense, such a principle as this. I It could be argued, for example, that many oraftsmen would do their job better if they understood the salentific principles which explain and predict the phenomena with whioh they work. In any ease, the current tendency in professionel. training seens to favour cutting down on the factually scientific elements in the course and concentrating more upon methods of procedure and the fostering of 'clear thining'. Hedical training courses are beginning to show drastic reductions in the baste seiences of blochemistry and physiology in order to allow more time for the development of professtonal skills. NacFarlane guotes with approval a British study which sets out four objectives for medical ecucetion:
1. Even if exafts were ruled out this critexion would admit an enomoug number of professional groups since these are multiplying at a staggering rate: the Mational. Register of Scientific and Techical Dersonnel in the U.S.A. classifies over 900 specializations compared with only 54 twenty jears ago, Bell, op, oite, p.76.


(2) The acquisition of a scientific method of thought i.e., the power to reason and think critically;

(3) The acquisition of competence in clinical method -the technique of obtaining information from patients;

(4) An understanding of the responsibilities of a professional person. 1

There is scant evidence here that a curriculum designed with the intention of securing these objectives would contain very much material from the underlying sciences and other branches of knowledge to which the Nuffield Report refors. Its main emphasis is clearly upon the quality of mind and the particular competenoies which a medical practitioner requires for successful practice, and if these are partly seen in terms of critical thinking and the use of scientific method then it could be argued that these are al so required by craftsmen in the exercize of theix skills. We do not want our doctor to diagnose our physical disorders by having recourse to astrology or necromancy; but we would be equally unhappy to discover that our plumer or motor mechanic made use of such procedures they need to utilize 'scientific method' just as medical men do.

1. MacFarlane, op. cit., cited on p.45. See al so: Report of the Royal Commission on Hedical Bducation 1965-68, london, H.M.S.O., 1968. 
If this particular selection criterion for the admission of professional studies to the universities is not very helpful then the one suggested by Hetherington is even more unhelpful. After pointing out, quite rightly, that the universities cannot hope to produce technically competent specialists since much of what they need to know can only be learnt on the job, he goes on to say that professional training in the universities should give students... an education for professional service.... The demand is not only for power, but for wisdom, 1 The trouble here is that this demand embraces everybody and is thus quite useless as an exclusion criterion. No matter what the job, the practitioner has non-technical demands made upon him: even the most routine and unexacting production-line job could be said to require this type of preparation if only to enable the operator to use leisure time to advantage or to enjoy good relations with employer and fellow workers. And who would be willing to say that he could not profit from more wisdom?

The fact that certain forms of professional training have traditionally been provided by the universities has rore to do with social class considerations than there being good reasons for theix engaging in this type of

1. Hetherington, The Social Function of the University,

op. cito, p.17. 
activity. ${ }^{1}$ If it is true that vocational skills are best acquired on the job rether than in the lecture room then this suggests efther that the univergities should shed their responsibilities for professional training -- which they do not discharge very well in any case -- or that they should take them much more seriously be designing radically new types of courses and providing far more in-service training. At the monent the universities fall between a number of stools in trying to do too many different things at the same time, with the result that higher education suffers and professional training, as Ortega pointed out, gets far less attention than it merits.

That justifications are offered for assigning to the universities some responsibility for professional training? The Robbins Report, as I have indicated earlier, relies very heavily indeed upon economic consideretions:

... progress - - and particularly the maintenance of a competitive position -- depends to a much greater extent than ever before on skills demanding special

1. That this is true of medicine was freely admitted in a report (1958) of the Royal College of Surgeons: '... there had al ways been a nucleus in medical schools of students from cultured homes .... This nucleus had been responsible for the continued high social prestige of the profession as a whole, and for the maintenance of medicine as a learned profession. Medicine would lose immeasurably if the proportion of such students in the future were to be reduced in favour of precocious children who qualified for subsidies from local authorities and the State purely on examination results'. S. Cotgrove, 'Education and Occupation', op. cit., quoted on p. 36 . 
training. A good general education, valuable though it may be, is frequently less than we need to solve many of our most pressing problems. I

... conceiving education as a means, we do not believe that modern societies can achieve their aims of economic growth and high cultural standerds wi thout making the most of the tellents of theix citizens. This is obviously necessary if we are to compete with other highly developed countries in an err of rapid. technologicel and social advance. 2

\section{All of this may be admitted, but it does not}

provide any grounds for the universities to undertake professional training. Neither is there any question of denying that society requires a continuous supply of skilled people: the question is, to what extent, if at all, should the universities contribute towards this supply? It is still far from clear how we are to go about answering such a question: much of the discussion of such issues fails to get to grips with the genuine problems because it tends to assume that all that is required is some tinisering about with current arrangements. Ortega forthrightly rejected this approach:

... the root of university reform is a complete formulation of its purpose. Any alteration, or touching up, or adjustment about this house of ours, unless it starts by reviewing the problems of its mission -- clearly, decisively, trutheully -- will be love's labours lost. 3

1. Robbins Report, op. cit., para. 25.

2. Ibid., para. 32.

3. Ortega, Mission of the University, op. cit., p.47. 
But rather than look at the mission of the university alone, we might make nore progress towards resolving the vocational training issue by viewing it from the other end, that is, by examining the demands of professional work and then determining how a course of training might best meet them. This might be more fruitful then squabbling about what is 'appropriate' to a university since this is usually determined on a priori grounds if at all. In order to keep the discussion as close to the ground as possible I shall take teacher training as an example, partly because it is a field of professional training with which I am most familiar, and partiy because responsibility for it is currently shared by universities with other institutions. So we need first to determine the skills and knowledge which a teacher needs in order to practise successfully. ${ }^{2}$ At once we are faced with serious difficulties, for there is little organized knowledge available. on this topic al though there are a great many conflicting opinions. All that can be said with any degree of confidence is that teaching is a practical activity which aims at the bringing about of learning in others. This

1. Some of the theoretical and practicel problems connected with the notion of 'teaching successfully' are considered in chapter VI. 
implies that teachers must know more than learners; but this is trivial. What professional knowledge and skills should teachers possess? They need the practical sicills which will lead to learning taking place and they need a body of theory which will enable them to justify and develop their theory in the light of practice and in terms of the way in which they conceive what they are trying to do.

The relationship between theory and practice is very unclear and poorly understood and this sometimes gives rise to unfortunate misunderstandings between practitioners and theoreticians. Thus 'academic lawyers' are sometimes referred to dismissively by solicitors and barristers who perceive them as being concerned with issues which appear to have little relevance to the realities of the court-room. General medical practitioners are sometimes uneasy about the connection between medical research and the special relationship which they have with their patients and which is taken to be the core of their professional work. But tensions of this kind are much more marked in the teaching profession: teachers are often cynical about the value of educational research undertalcen by people who are remote from the classroom, and theoretidians often suppose that teachers proceed largely by rule of thumb and lack any 
rationale for what they are doing. In general, we might expect such conflicts between practitioners and theoreticians to be most in evidence in fields where there is an abundance of 111-defined abstraot ideas: education offers an outstanding example of such a fleld.

That there are such misunderstandingsis scarcely surprizing since it is only in very recent times that practitioners have had very much to rely upon in the way of theory: previously they had managed largely by rule of thumb guided by the practice and precepts of their predecessors the significance of theory was barely appreciated. Teachers, for example, picked up their skills and knowledge on the job since there was little for then to know which they could not quite easily discover for themselves in the course of their practice. Mraining colleges for teachers were largely concerned with passing on information about methods of teaching and with attempting to oultivate in the student a minimal competence in classroom management. Teachers were trained by what wes essentially a system of apprentice-ship, but what was passed on in this way extended fas beyond practical information on how to donduct oneself in the classroom. The student also acquired a recelved body of opinion on what should be taught, the ways in which it should be taught, and the principles supporting the 
organization of the eduoational system. He wes thus the inheritor of a settled tradition.

This situetion has now been almost entirely transformed. Training now needs to take account of the changing character of the teacher's task and the stremuous demands which this makes upon his skill, judgment and intellisence compared with the requirements for success in the classrooms of even twenty-five years ago. This, in turn, has led to a rapid growth in the body of theory associated wi th education, and it is the failure to make important distinotions within this body of theory which has largely been responsible for many of the misunderstendings between theoreticians and preotitioners. It has also been responglble for much of the theory remaining in a relatively primitive condition and for some of the gross inadequacies of teacher-training courses.

It is possible to discern at least three kinds of theory associated with education, each with a different function in relation to the prectical activity of teaching. The first night be called the 'theory of teaching' since it is directly connected with what teachers actually do in their classrooms. Any discussion of teaching methods, of classroom organization, of particular teaching episodes, of the teacher's manner, and of the behaviour of particular 
children - all of these fall under the heading of the theory of teaching. During teaching prectice most of the discussions between student and supervisor will be of this kind. Its relevance to teaching as a practioal sctivity will be imediately obvious to the student, and, indeed, to any teacher who reflects about what he is doing with the aim of trying to do it better. There is little likelihood of a conflict here between theory and practice.

There is another body of theory which is less directly related to teaching as a prectical activity: this might be called the 'theory of education'. This is concerned, in the main, with much larger questions than those which arise in the course of trying to teach $X$ to $Y$. It relates to the rational background to educational practice: educationel theory is concerned with education as an enterprise and only indireotly with tesching as an activity. Much of the theory in this category will, of course, bear upon teaching, but its bearing will not have the obvious immediacy of the theory in the first category. Failure to perceive the indirect nature of the connection between educationel theory and teaching has led to a good deal of misunderstanding on the part of practitioners of what theorists are trying to do. 
There is a third type of theorizing about education which is completely disconnected from the practice of teaching and which might be called the theory of educational ideas'. Thus historians, philosophers, econonists, psychologists, sociologists and anthropologists might take an interest in educational matters simply from the point of view of their own disciplines rather then in response to the practical problens which confront teachers and educators. The history of education would be a branch of historical studies in the same way as are the history of science and the history of medieval. Burope; that is to say, it would be a theoretieal structure built out of the distinetive concerns of historians and intended to add to our historical understanding of educational ideas, practices and institutions. It night be thought that teachers should know something about the history of education, but it would be extremely difficult to justify this on the grounds that it contributes to the teacher's effectiveness in the classroom. Such knowledge could, however, perhaps be justifled by showing that it is helpful in understanding educational. theory (the second category) and in producing new or modified theories.

1. See: J, T. Tibble (ed), the Study of Education, Iondon, Routledge, 1966. 
Then considering what theoretical equipment a practitioner requires we have to look closely at the nature of his work since the sole justification for each of the elenents in a training course is that they are useful for practice. Teaching presents an immediate problem here since It is extremely difficult to detexine the range of a teacher's tasks: a large number of these obviously relate to the daily round of instruction, but there axe also many others which concern the construotion and jus ifioation of the curriculum, his relationships with his colleagues, his place in the school as an institution, contacts with parents, 'political' activity directed towards improving the phystcal conditions of teaching, and his attitudes towards his pupils as individual human beings rather than as pupils who happen to be members of his class, The responsibilities of teacherg are thus extremely diverse and complex; so much so that it is not ridiculous to suggest that almogt every thing in a teacher's educational and training experiences can be seen as making some contribution to success in his profession. But not everything is equally relevant and the time available for professional training is limited; this means that choices must be made in order to construct a curriculurn.

The distinctions made between various types of theory may be helprul here since they depend in part on 
differing relationships between theory and practice. Teaching is not a purely practical sativity in the sense that it could proceed without the aid of theory - there are probably no practical activities which are 'pure' in this sense -- since every teaching act pre-supposes certain intentions and beliefs on the part of the teacher. Bvery teeching transaction needs to be guided and evaluated by some theorizing as to its purposes and chances of success: there is thus no gap between theory and practice and no problem about the relation between theory and prectice. Those who have suggested that there is such a problem have simply been mistaken: a moment's reflection upon the nature of any teaching episode shows immediately that what teachers do and what they think are intimately related. The problem is that some of theix theories are erroneous and some of the theoretioal material in training courses is not relevant to practice. Much of what I have called the theory of educational ideas falls into this latter category: it simply cannot be shown to be related to the professional tasks of teachers in any convineing way.

since pure research is primarily an activity concerned with the development of explanatory modes of thought we would expect some aspects of teaching, medical and legal practice to be of interest to scholars; but such interests are scarcely likely to co-incide with what is of 
centrel concem to the practitioners. Scholars are more likely to be atracted to the noture of legal. mules than the teohnique of presenting a case in court, to the history of medicine than the diagnosis of schizophrenia, to theories of learning than to the details of teaching the besic operations in erithmetic. But insofar as the universities have underteken professional training the courses provided have tended to consist of selected pieces of those scholarly disciplines Which appear to have some connection with the profession in question rather than be tailor-made to the future needs of the student. This is particulerly true of tescber-treining programmes: the universities have never given these their whole-hearted support and have consistellty failed to respond to the requirements of the profession as a whole. Ortega was surely correot in claiming that the universities' contribution to professional training has been totally inadequate, and this has been largely because they have failed to distinguish sharply between vooational training and higher education with the result that neither has been done well.

Perhaps we are now in a somewhat better position to look again at the question of the justification of the universities' involvement in profescional training. As was shown earlier, the usual argunent advanced to suppoxt some involvement is one which turns upon the extent to which the professional expertise in question relies upon the theoretical 
knowledge genereted by pure research. The Nuffield College Report, for ezample, says thet there is a case for including professional studies if these rely upon 'underlying sciences or other branches of knowledge' which the university is elready engaged in exploring. In other words, the university is not under any obligation to moke any speciel effort to solve special professional problems but only to allow students to participate in some of the activities which are already being carried on within the campus. To judge by many existing professional courses this prineiple is in fact being quite extensively employed. Its consequences are only too evident: many problems which are of central interest to professionals are either ignored or treated almost exclusively from the viewpoint of current developments within the of reference

scholarly disciplines. The freme $\wedge$ many people who teach such courses lies in sociology, physics, psychology or history rather than in the profession for which the programme is ostensibly a preparation. Again, this is notably the case with teacher-training. Another consequence is that the distinction between theory and practice is applied in such a way that the theory which is taught becomes that which relates most obviously to one of the academic disciplines rather than to what is required for successful practice wi thin the profession. The Nuffield College Report explicitly recomends that the practial training should be 
done elsewhere, in technical colleges for example. This geveals both a misunderstanding of the connection between theory and practice and the strength of the assumption that the universities should concern themselves only with theoretical, investigations directed towards pure research. It is just not posaible to separate theory from practice in the manner required by this view of professional training: it makes no sense to suppose that the practical work of teachers, doctors and lawyers in training could proceed independently of quite basio theoretical considerations. The whole point of the theory is to determine, guide and modify the practice, and unless the theory and practice are tightly enmeshed then the one becomes irrelevent and the othex becomes mindless routine.

The issues here are fairly simple, although their practical resolution is mach less so. The earlier analysis of pure and applied research suggests that scholarship and professional training are incompatible activities: the problems encountered by the pxofessions and their training programes are not likely to be solved by those who are pursuing knowledge for its ow sake since the directions taken by pure research are determined solely by the interests of scholars. Applied research, on the other hand, can readily be direoted towards whatever dif iculties perticular 
prolessions are currently meeting. Therefore the universities mat decide the extent to which they wish to take propessional training seriously since this will entail diveruing a considerable paxt of their resources to the teaching and research problems which this will inevitably produce. Lord Robbins has recognized that 'The questions involved are of an appalling intellectual difficulty ....1. but many university people still appear to suppose that professionat training is a comperatively simple matter and somewhat beneath their intellectual dignity. They must either take it seriously or abencon it to those who are prepared to do so: the new polytechnics will no doubt be eager to take it over.

\section{The University and Higher Education}

The most striking and remarkable feature of the Robbins Report is thet, despite its title, it says vixtually nothing about higher education. After discussing education viewed as a means to economic growth the report continues:

But beyond that, education ministers intimately to ultimate ends, in developing man's capacity to understand, to contemplate and to create .... The good society desires equality of opportunity for its oitizens to become not merely good producers but al so good men and women. 2

1. Lord Robbins, The University in the Wodern World, op. cit., p.28.

2. Robbins, Report, op. cit., para. 33. 
The same point is being rade, I take it, at the beginning of the Report where one of the objectives of a system of higher eduoation is said to be,.. to produce not mere specialists but rather cultivated men and women, 'I 'Cultivated' here is to be construed as possessing '... that background of culture and social hebit upon which a healthy society depends'.? Nothing further is said about the nature of university education except for the claim that: The essential alm of a first degree course ahould be to tench the student how to thines. 3 3

Forbunately, the 11 terature conteins plenty of accounts of the character of university eduoation, many of which contain similar references to its association with intellectual training and the production of 'good men and women'. Newman, for example, summed up his account of the nature and purposes of university education as follows:

A university training aims at raising the inteliectual tone of scoiety, at oultivating the public mind, at purifying the national taste, at supplying true principles to popular enthusiasms and fixed aims to popular aøpirations, at giving enlargement and sobriety to the ideas of the age, at facilitating the excrcise

1. Ibid, para, 26.

2. Ibia., para. 28.

3. Ibia., para. 254. 
of political power and refining the intercourse of private life. 1

There is no mention here of any suggestion that university education might increase the productivity of Victorian Britain, but then Newman was at pains to deny that higher education was in any obvious sense 'useful': when pressed, he was only prepared to say: If then a practical end must be assigned to a University course, I sey it is that of training good members of society'. ${ }^{2}$ He saw the university's contribution to education as being primarily a social training which would produce gentlemen able to take their place in Society, but the form taken by the training was to be predominantly intellectual in cheracter since gentlemen were also scholers, pursuing 'Tiberal Knowledge' for its own sake: '... Liberal Education, viewed in itself, is simply the cultivation of the intellect, as such, and its object is nothing more or less than intellectual excellence $\ldots 3$ J.S. Mill also denied that it was the university's job to train people for the professions. A university, he claimed:

1. J.H. Nerman, The Idea of a University, op. cito, pp. $177-8$.

2. Ibid., p.157.

3. Ibid., p.107. 
... is not a place of profesetonal education.

Universities are not intended to teach the knowledge recuired to fit men for some special mode of gaining their livelihood. Their object is not to make skilful lawyers, or physictans, or engineers, but capable and cultivated human belngs. I

Professional skills are necessarily specialized and are therefore needed only by comperatively small numbers of people: they are thus best acquired, according to Mill, after general education has been completed. But everyone needs to be educated since all men pertake of a common humanity and are bound to encounter common problems in life ixrespective of their partioular professionel calling

Hen axe men before they are lawyers, or physicians, or mexchants, or manufecturexs; and if you make them capable and gensible men, they will make themselves capable and sensible lawyexs or physicians. That professional men shovid carry away with ther from an

University, is not the prolessional. knowledge, but that which should dixect the use of their professional knowledge, and bring the light of genexal culture to ill uninete the technicalities of a special pursuit. 2

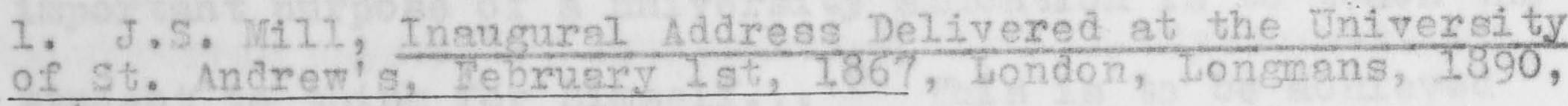
$\frac{0.5}{p \cdot 4 .}$

2. Ibid., p.5. Since Mill's day the problems involved in directing the use of professionel and scientific knowledge have become increasingly acute: "Tuman scientists now have it in their power to redesign the face of the earth, and to decide what kind of species shell survive to inherit; it. How they actually use this terrible potentialiby must depend on moral judgments, not on reason .... The moral doubts of those who helped to design the flrst atomic bombs have become notorious, and today there must be thousands of highly qualified scientists enseged on hundreds of different chemical. and biological research projects who face similar difficulties B.R. Leach, 'Then cientists Play the Role of God', The Mimes, 16 November 1968. 
A tha for difrieutog wh such vieve is that of Interpreting such expresstions as capable and cultivated human beings' and 'men are men bofore they are ' 1 wivers'. Are they to be conetrued solely ta bexth of intellectubl. cepacities or in bexus of solie wider notion suoh as that of 'person'? - Both interpretations ate to be found tin the 1.teratuse, al thouch a majort $\psi$ of of heoristolnevenstreased

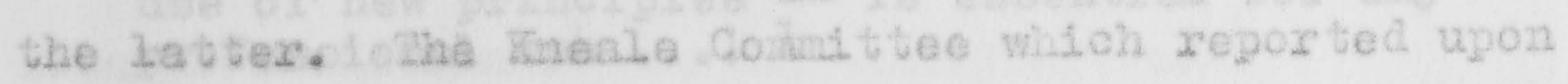

examinations at oxford saw the purpose of universit ty eduoavion as being the produotion of lesdera of socie tu requipped with: '... eextain traits of cheracter, such as openzesa of mind, breadth of sympathy, and power of oritioal. Judgenent, that are thought to be fostered by aoademio otudies. 1 . The Hal, comittee on university teaching nothods alao stressed the importance of intellectuel treining: '... the most important purpose of a university education is to teach the student to think for himself....2 Thid is to be sohieved through: '... the development of a wind and 1 ts training in method and attacix...13 An Austrellan report on the same

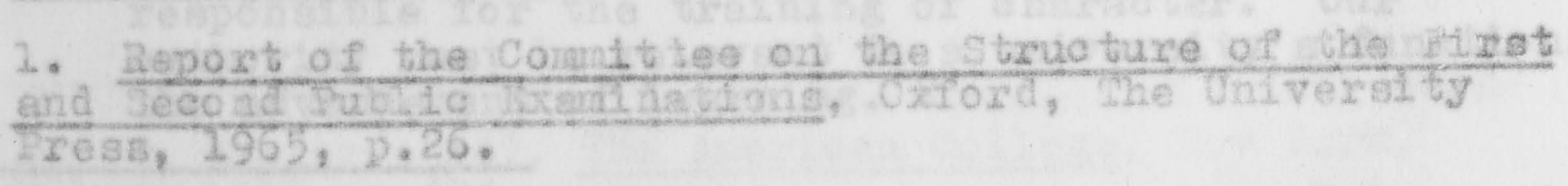

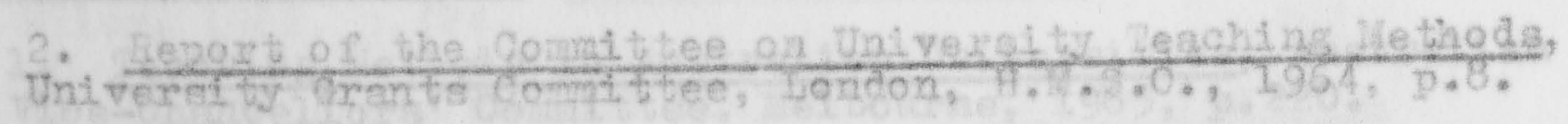
3. Ibia, $2,2$. 
topic indicates a similar coneern with intellectual development:

It is relatively easy to test whether an undergraduate has learnt what he has been taught; it is meh nore diffioul to test whether he has developed flexibility of mind, a heal thy scepticism about the finality of whet he has learnt, and a capacity to absorb fresh ideas.... The capacity to find out for oneself - - even if it means nothing more than the capacity to examine new claims critically, to read the literature with care, to understand how to make use of new principles -- is essential for any professional man .... 1

The claim that university education is concerned only with intellectual development is usually justified by appeal to the qualities of mind which are required for pure research. The disinterested pursuit of truth, if accepted as the basic task of the universities, is scen to denand a purely intellectual training and to provide no justification for the fostering of other qualities in students. The nature of university education is thus completely determined by whatever capacities are required for the advancement of learning:

We are comitited to knowledge and to truth, not to the 'development of personality', still less its

'expression'; al though, it is fair to add, nor are we responsible for the training of character. Our authority must be relevant to a university's function: the advancement of learning. 2

1. Ieaching We thoas in Australian Universities, Australian vice-Chancellors' Committee, elbourne, 1965, p.220. 2. B. Crick, 'Student Power', The Observer, 10 November 1968. 
Against this there is the viow that education involves a good deal more than the promotion of intellect; some have even gone so far as to see higher education almost entirely in terms of personality development. Sanford, for example, in discussing the Amerion college curriculum, clains that: It is oriented to the development of the personality. This in our view is the prime meaning of liberel education'. I

Nost theorists adopt a position midway between these two they treat intellectual development as a part of what is involved in helping students to become 'mature adults'. Patterson and Longsworth, for example, in their acoount of the establishment of Hampohire College, say that: The central task of liberal education at Hampshire College is to help young men and women to live their adult lives, fully and well, in a society of intense change, immense opportunity, and great hazards'. ${ }^{2}$ They adnit that this sounds like 'most college catalogue rhetoric' but see it as meaning that '... the college must help them acquire the tools with which it looks as though men in the future may

1. N. Sanford (ed), The American College, New Zork, Wiley, $1962, \mathrm{p} .424$.

2. F. Patterson and O.R. Iongsworth, The Naking of a College, Cambridge, Nass., Mi.I... Ires., 1966, p.44. 
be most likely to be able to build lives and a society they considex worthy'. I This clearly involves a good deal nore than the purely intellectual training required for the pursuit of knowledge for its own sake.

Many British writers on the universities see a gimilar connection between intellectual growth and the capacity to deal effectively with personal and social problems. Hetherington, for exemple, says:

No one but surely feels that an educational process is incomplete which falls to help a man to come reflectively to sone affirmation on the central. i.ssues of his personal and social life, to know intelingently what he believes, and where his primery loyalties should 1ie.?

SIoman expresses a similar point of view in his aceount of the foundation of the University of Essex:

... the university ought to have allowed him [the student] the chance to think and argue about the fundamental problems of $11 \mathrm{fe}$, and to stand on his own feet; it should have given him a respect fox learning and for people, and developed his character .... A univereity should, I believe, provide an experience of $11 \mathrm{ving}$ as vell as an opportunity for learning. Wi thout this, education is dehumanized, the student himself defrauded. 3

1. Ibid., p. 45.

2. Hetherington, The Social. Function of the University,

op. cit., p.25.

3. A.T. Sloman, A University in the Natcing, op. oit., pp. $50-51$. 
The view that higher edncation is concerned with the whole person rather than one aspect of life was graphically expressed by Ortega: The university must be the projection of the student to the soale of an institution. And his two diriensions are, first, what he is - - a being of limited leaming capecity - - and second, what he needs to know in order to live his life. " More recently, there has been growing concern, especielly on the pert of some students, that higher education all too often 1 gnores students as persons and instead is increasingly sheped by vocationaligm and a narromness of intellectulal reference. A National Union of Students dooument clains that: There is a exisis about the way education todey is being run, a crisis about the airection of education, a exisis in the system between the needs of society, and particularly of economic expansion, and the needs of the individual'. ${ }^{2}$ Simon Hoggaxt, reflecting upon his experiences as ari undergradua te at Cambridge, say s:

What students want, I think, nowedays, is a sense that the work they are doing has some purpose; that it links to something more jimportant than itself, that connections - a key word - - can be made between literature and society, economics and politics,

1. Ortega, Mission of the University, op. cit., p.70.

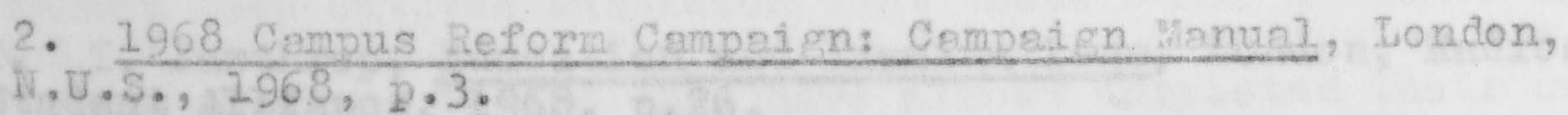


science and morals, and all subjeots with each other. Perhaps the connections axen't there to be made; if so, we want to lnow, and at least we want to make the effort to establish them. No wondex the philosophy of student protest is so appealing - it draws together the individual, society, the university, and the great outside igsues.1

Finally, another student puts together a view of higher education which combines both notions, the intellect and the person:

Bducation is a public process of acquiring knowledge, involving a synthesig of facts and ideas, the cultivation of intellectuel cuxtosity, mentel alertness and a aritieal mind.... It also involves the humanistic concoption of developing man as a totel being, bringing out the person - - and the personelity - in such a way thet he is intellectually and emotionally equipped to face and confront the problems of life -- both his own and the lives of militions of other fellow inhabitants of the univerge .... Bducation should not only provide society with an intellectual conscience but a social. one as mell, which is incapable of tolereting the spixitual and material poverty of the present human condition. 2

\section{These two pesseges indicate a conception of}

Tnowledge and understanding which is considerably wider than that adopted by those who support the doctutne of lenowledge for 1 ts own selve: the educetionel. consegrences of connecting knowledge with sociel problems, velues and personel sotion are likely to be merkedy different from those which would

1. S. Hoggart, 'Cambridge Anti-memories', The Guerdian, 17 cotober 1968.

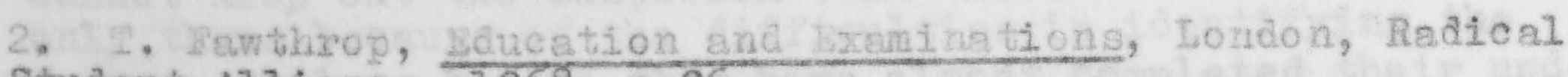
Student Alliance, $1968, \mathrm{p} \cdot 26$. 
follow from knowledge seen solely as being of intrinsic worth. Henee the scope for quite wide disegreement about the general character of the education which the univergities should provide. If it is seen as a preparation for the exercize of the specialized intellectual skills possessed by scholars then it will be a form of vocstional training sather than a continuation of what is offered by the sehool system and could thus justifiably be restrioted to the relatively small nutiber of those who are likely to spend much of their lives as scholars and research workers. ${ }^{1}$ But if higher education is conceived more broady as being concerned with intellectual and personal development at a high level (the 'tertiary' level) then there would seem to be no reason for not making it available to everyone who is capable of gaining something fromit. It is therefore of considereble importance

1. Besil Mitchell seys thet in addition to the tesk of training future scholers the universities have',... also been entrusted with the thalc of educatine students who are not going to be professionel scholars. They are given the same sort of intellecture troining as those who are, for a number of reasons: it's a tough intelleotual training which sets an exscting standard; it represents an ideal of di sinterested inquiry ... it trensmits to the student some part of our inherited culture...' B, litohell, letter to The Mimes, 6 Pebruary 1968 . But the se reasons are identical with those which justify what the future scholars are offered: one cannot keep out the suspicion that these other students are anly there because of the difficulties in identifying the future scholars before they have almost completed their undergraduate work. 
to be clear about each of these interpretations and to determine the grounda for adopting one xather than another. I have been uging 'higher education' and 'university education' interchangeably, a usage with which some people movid aisagree.

F.R. Leavis, for one, wishes to draw a sharp distinction between these two concepts:

Bssential truths have been almost forgotten. Mirstly, the phrase 'the standards proper for a university' means something. Secondly, to identify the problem of Higher Bducation with the idea of the university is dissstrous; for, thirdly, if standards are not maintained at the university the advance of Higher sucetion will. (for one thing) be grievously disabled. Nelther democratic zeal nor egalitarian jealousies shouid be permitied to atsmiss or ascredit the fact that only a limited proportion of any young adult age group is capable of profiting by, or enjoying, university education. 1

Leevis does not sey what he means by 'university standards' or 'university education', el though it is reasonable to infer that he has in mind what now obtains at Oxford and Cambridge. Neither does he sey anything to clarify the distinction which he makes between 'higher education' and 'univergity edueation'. Mis elaim that only a mall number of people are capable of profiting by or enjoying unfversity education is not supported by any evidence (although it may well be true at the present time)

1. I.R. Leavis, letter to the Mimes, 22 January 1968. 
and he fails to realize that the same point could be made with respect to secondery education. Yet, even if this could be established, he would not presumably be persuaded by it that only a minority should be allowed to continue at school bejond the age of eleven.

\section{Another supporter of the distinctiveness of} university edueation is Michel Oakeshott who argues that each stage in educationel. provision is to be distinguished by the type of educational experience which it offers: 'I believe that university education is a specifio sort of education .... And I believe, consequently, that every component of a university ecuostion is properiy a component in virtue of having a certain character or propensity', 1 Oakeshott denies that university education is in any sense a continuation of what is provided by the schools or that it is a form of vocational training. The latter, he says, involves learning one of the skills of contemporaxy life:

In other words, a 'vocational' education is education to fit a man to fill a specitio place in a current manner of living, or to satisfy a curcent demand. And conseguentiy, it is not utterly far-fetched (as it would be in the case of school education and, as we shall see, of a university education) to attempt to determine' the number of persons who are needed to be trained in a particular athl1 if a current manner of living is to be sustained. 2

1. M. Oakeshott, Rationalism in Politics, Jondon, Methuen,

$1962, p .303$.

2. Ibid., p.309. 
There is a fim denial hexe of the type of claim made by Leavis that university education is to be restricted to a quite small group of people; instead, universi ties are placed in the same category as schools as for as accessibility is concerned. But what is the 'certain character of propensity' which constitutes the unique featuxe of university eduortion? For Oriceshott, this lies in the exploration of ' an explanatory manuer of thinking and speaking': the nature of univerdity education is thus determined by the activities of scholars engaged in the pursuit of knowledge for 1 ts own sake through the various modes of intellectual inquixy which have been developed over the centuries in ordex to explain experience. A university education is therefore an induction into these specialized and unique inteliectual enterprizes:

That a university has to offer is not information but practice in thinleing; and not practice in thinking in no manner in perticular but in specific menners each capable of reaching its own characteristic kind of conclusions. And what undergraduates may get at a university ... is some understanding of what it is to think historiceliy, mathematically, scientifically or philosophicelly, and some understanding of these not as'subjects', but as living 'lenguages' and of those who exploxe and speak them as being engaged in explanatory enterprizes of different sorts. 1

1. Ibid., p.313. 
Oakeshott's position is thus firmly in the tradition of thought which conceives university education as providing an intellectual training and, st the sane time, an induction into 'the whole intellectual capital which composes a civilization'. He explicitly disconnects the thinking which this process involves from both prescription and action: the knowledge in which the university deals is concerned only with explanation and its study is uncelated to practical utility and disengaged from our approval or disapproval:

To be an undergraduate is to enjoy the 'leisure' which is denoted by thinicing wi thout having to thin's in the pragnatic terms of action and taliking without having to speak in terms of prescription or practical advice -- the 'leisure', in short, which distinguishes the peculiar academic engagement of explanetion. 2

This is undoubtedly on accurate description of much of the training which the universities in fact provide, but whether or not one considers it an acceptable account of the nature of higher education depends upon one's view both of knowledge and of education. In the light of the analyses in the preceding chapter, Oalceshott's theory of university education follows naturally from a view of the university as besicaliy an institution devoted to pure research; in fect,

I. Ibid., p.310.

2. Ibià., p.315. 
he explicitly dertwes his theory from such a view. But for anyone who insists that knowledge must be social, IJ applicable or who sees education as being, in part at least, concerned with the fostering in students of a commitnent to values and to rational getion, what orkeshott has to say must inevitably appear inadequate.

Disregarding its acceptabiliby in general, what he says will scarcely serve to establish the uniqueness of university education since the schools are also engaged in introducing children to distinctive explanatory modes of thought. At one time it mey well have been true to say that sohools were excessively devoted to the passing on of facturl information and negleoted to give children practice in thinlting. Dut nowadays increasing stress is being placed, even (or especially) in the primery schools, upon understanding, explanation and exploration, Given Oakeshott's theory of education as the process whereby we come to inherit the intellectual cepitel of our civilization and at the same time graduatly discover and eultivate our own notures, it seems odd that he should choose to construe this process in terms of specific kinds of education. His account argues strongly against doing this sinee it encouragestus to see nost of the learning which occurs in primary schools, secondary schools and universities as being essentially directed towards the same objects: the advancenent of 
undergtanding and the growth of self-lenoviledge. What he says about the distingul shing maxks of the various stages of education is perticularly unhelpful, if not totaliy mistaken. Of school education he says: 'I' is leaxning to speak before one has anything signilicant to say; and what is taught must have the gualities of belng able to be learned without necesserily being understood..... This is net ther an accurate nor a flattering picture of what goes on in schools ('good' schools, enywey): and even if it were acourate it could then be made to fit much of what goes on in universities equally well.

If 'education' is treated as a unitery concept then we shall not be tempted to malce 1 mplausible distinctions between primary, secondary and higher edueation. Instead, these stages in educational provision can be viewed as segments of a continuum which satisfies at every point the same set of exiteria. The cutmoff points of the segments or steges are arbitrary, chosen mainly to suit acministrative convenience and to accord wi th levels of maturation and attainment: they do not indicate thet different criteria are being applied at each stage or even that redically different activities ere to be found in each of them. There is not that much difference between what the undergraduate

1. Ibid,, 306 . 
mathematieian does and what is done by the prinary school child making his pixst steps in the understanding of number. ${ }^{2}$ Nevertheless, if we wish to distingulsh between different segments in the educationat continuun it ia not too difficult to to so by attending to the kinds of demands which are made upon the learner. As his education progresses he $1 \mathrm{~s}$ requires to remember more information, to perform with increasing skil1, to make finer discriminations, to Judge with greater accuracy, to be more om tical and more imaginative, to worls with greater attention and coneentration for Longex periods of time, to feel more deeply about the value of what he is doing, to reach townrds deeper levels of understanding, handle more complex problems, to speak and write with greater flueney, and 60 on. We cen readily see that there are imense differences in these respects between undergradustes and children ix primexy schools, but these

1. 'For foux years I combined work in primery echools with university teachiag. It meant ending a class at four o'olock in which, perheps, eleven-year-old children painted to music, or built up tiny dance dranes out of familiax domestic teristons - and stexting a class at six o'clock in which twenty-yeax-0.1d students worked their way into zuxipldes or Tourneur. The switoh from class to olass never felt $11 k \mathrm{ke}$ a leap into a new element - more a move along the gpectrum.' Brian Jackson, 'Plowden and the Universities', Univergities quarterly, xxx, 373-5, 1967, p.373. See also the extremely interesting and perceptive work of John Holt, especially his most recent book: How Chilaren Learn, London, Ditman, 1968. 
developments occur imperceptibly over lengthy time-spens and It is never possible to say that sherp breaks in attainment and capacity are evident at certain points in the continuun. Another reason for rejecting the view that there are different kinds of education can be derived from the fect that the skills and understanding which ere centrel. to education are not subject to masteries. In the primary school children take their first gutded steps towards coming to understend the distinctive ways of organizing and explainIng experience, they extend thei $r$ control of language and their conceptual repetolre, they begin to appreciate music and literature, they begin the life-long business of learning to live with other people, and they gain some insight into their own natures and the ways in which these may be governed and developed. In the secondary school these early schievements are continued to levels of increasing complext ty, and they beoome still more elaborate at the tertiary stase. At the level of higher education a number of things can be taken for eranted: students an be expected to be punctual, polite, honest, Industrious, interested in what they are doing, and so on. But these features of behaviour are neglected because they no longer need to be attended to, not because they no longer matter. A great deal of knowledge, skill and understending can also be assumed in the later ptages: this is why they are called 'secondary' and 'bigher' 
or 'textiary'. The learnex already possesses desirable knowledge, skills, attitudes and values; but these are all of such a character that they are capable of indelint te extension end deepening. That distinguishes higher eduoation from other segments of the educationel contimum 1 , as I shall axgue in the next chaptex, that it brings the learner to the strge at which he is equipped to proceed independent1y in that he no longer has need of edueational progremes axranged for him by others: his attelnments are such that he is able to proceed independentzy.

\section{An educational programme for higher education}

thus continues the proceases which have been begun at earlier strges in the Learner's ealuestionel career: it does not represent a new deperture xadicelly different from what has gone before. This inplies that any institution which elatms to be engeged in higher ecucation must shere the concern of the schools for continuing to involve the learner ever nore deeply in a wide range of cognt tive and affective experiences. It rust care about the ways in which a student behaves, about his beliefs and values, and about the extent and the guelity of his knowledge and understanding. In short, it mugt be profoundly concerned with $h i m$ as a person rather than simply furnishing him with marketeble sirsils or with the specialized knowledge and techniques associated with scholarship. 
There are therefore good reasons for treating higher education as providing 'an education' in much the same sense as the primary and secondary schools provide an education, that is, ss contributing to the all round intellectual and personal development of the individual so that he is able, when his higher edacation is successfully completed, to play a full part in a democratic society and to make a rational decision as to what he will do with his life by way of eaming a living. This was what J.S. Mili and others had in mind when they spoise of the university equipping people for professional service, not in the sense that they were furnished with the technical skilis to practise a perticular profession, but rather that they were brought to the point at which they could exercize judgment and good sense in whatever calling they decided to take up. It follows from this that highex education can only concern 1tself with professionel treining insofer as this can be used as a vehicle for the development of the required personal andintellectual qualities. It also follows thet higher education cannot be solely concerned with the fostering of purely intellectual capacities: at present many univeraity courses succeed in meeting society's domands for experts only at the expense of neglecting the preparation of students to share in the wider responsibility required for the heelthy functioning of a democracy. And finelly, 
this implies that higher education should be seen to be the right of all-given that the schools have brought them to the stage at which they can cope with 1 ts demands - - and that we should envisege a time when the universities vill be firee from their present elitism and the extremely restrictive entrance procedures which are only justifiable if one assumes, with Leavis, that a university training is quite digtinot from whatever is involved in higher education and by definition suited only to a small minority of students. As Eric Robinson has correctly pointed out, the Robbins Committee assumed that higher education was to be reserved for an elite minority and the main problem, as they saw it, was how to increase the size of this minority without destroying the universities as we know them. But there is no reason to accept this assumption, even though its rejection does entail either quite drastic changes in the univeraities or the development of new types of institution -- we seem extremely reluctant to face up to either of these consequences. Whether the new polytechnics are capable of developing into what Robinson calls 'comprehensive people's universities' remains to be seen. ${ }^{1}$

In this section two interpretations of 'higher education' have been identified: that which sees it

1. E. Robinson, The New Polytechnics, op. cit., p.11. 
primarily in terms of intelleotual training, and that which views it as a contribution to the general educational process of 'personal development'. Each of these must now be examined in detail in order to give them some substantive content. But first it is necessary to look again at the five functions of the universities which heve been considered so far in order to discover what relationships hold between them and which, if any, depend upon others. It should then be possible to give sothe kind of an answer to that troublesome question: 'That are universities for?'

\section{Punctional Priorities and Compatibilities}

It may be helpful to disregard both the historical growth of universities and what they actually do at the present time and begin instead by looking at the five functions which have been discussed in these two chapters with a view to determining those which must be pre-supposed if the others are to be carried on. For example, if higher education is conceived as the induction of students into the activity of pursuing knowledge for its own sake then it cannot possibly get off the ground unless pure research is already being engeged in. The very act of teaching presupposes thet there al ready exists something which may be taught to tho se who are ignorant of 1t. Similarly with professional training: this cannot be undertaken unless 
people are already exercizing the skills which are to be passed on to students. The same point can be made with respect to applied research: the knowledge and skills which this demands must already be possessed by somebody if they are to be tanght to future research workers. The claims of a university to be a cultural centre, in both of the senses considered earlier, must also be assumed to be valid if the existence of such a centre is to be maintained by introducing others to its activities and values.

What is at stake here is a purely conceptual point about the nature of teaching which suggests that the teaching role of the university is logically parasitic upon some of its other functions. But this does not establish thet activities which are related in this way must be undertaken either by the same group of people or within the sane institution. Traditionally, the universities have in fact made provision for both pure research and higher education, al though not everyone perceived that there was anything necessary about this association. I Is there anything about the nature of higher education which requires that it be

1. Newmen, for example, said of the university: That it is a place of teaching universal knowledge. This implies that its object is, on the one hand, intellectual, not moral; and, on the other, that it is the diffusion and extension of knowledge rather than the advancement. If its object were scientific and philosophical discovery, I do not see why a University should have students.... The Idea of a University, op. cit., p.xxvil. 
provided by those engaged in scholarly activities? It is often asserted that pure research and the provision of higher education are mutually supportive activities: what is there to be said in favour of such a claim? The Frantrs Commisstion received many submissions in oral evidence arguing that research and teaching were best done by the same people:

The teaching in the colleges would not be so good unless those doing it were also engaged in original research. It may be true that it is no longer possible in the course of an undergraduate's career to take him right up to the frontiers of knowledge .... Nevertheless, his education would suffer if he were not working closely with someone who is a pioneer and who therefore teaches 'as one having authority and not as the scribes'. A divoree of teaching from research ... would also adversely affect the academic succession in retarding the development of the minority who aim at becoming research workers in their turn. 1

\section{The Robbins Report argues that teaching and}

research are complementary and overlapping activities: 'A teacher who is advancing his general knowledge of his subject is both improving himself as a teacher and laying foundations for his research. ${ }^{2}$ students need to be inspired to learn and work:

Here an ounce of example is worth a pound of exhortation. The element of partnership between teacher and taught in a common pursuit of knowledge and understanding, present to some extent in all education, should become the dominant element as

1. University of Oxford, Report of Commission of Inquiry, vol. i, Oxford, Clarendon Press, 1966, para. 211.

2. Robbins Report, op. cit., para. 557. 
the pupil matures and as the intellectual level of work done rises. 1

Although only a minority of students will be going on to post-graduate studies, 'It is of the utmost importance that the ablest, who are capable of going forward to original work, should be infected at their first entry to higher education with a sense of the potentialities of their studies:?

These erguments are not very convincing. If 'research' is given the interpretation placed upon it by the Franks Comaission, namely, the making of pioneering and original contributions to knowledge, then it is highly implausible to assert thet undergraduates cannot be taught effectively by people not engaged in research. For one thing, most university teachers are not pioneers in this sense; most of them count themselves fortunate if they are able to understand what the original thinkers in their discipline are doing. But inevitably they know a great deal more than their students and it is enough if they are able to communicate some of their own understanding with enthusiasm and with insight into the learning problems which confront undergraduates. In order to be able to do this

1. Ibid., para. 555.

2. Loc, cit. 
succesefully they must, of courge, keep up with their subJect by reading and reflection, but it is not necessary to have an original and pioneering mind to be able to do this. It is equaliy doubtful that potental scholara and research workers w11 suffer during thelx undergraduate years if they are not teusht by originel thinkers. The enoouragement and identification of outetending students is well within the cagsel ty of all univereity teachers: they need not thenselves be oxiginal in orcer to be sble to recognize glens of that quelity in the work of others. It is asaumed by those who wish to preserve a very close comeclion between teaching and research that those who ere outetenaing in the letter ectivity will be equaliy successful in the former, whereas this by no means Lollows. I One could essune, with the same justifiestion (that is, vixtueliy none) that success in research militates ageinst success in teaching. If this were true, then we

1. A point which was made by Nevman: the nature of the case and the history of philosophy combine to recomend to us this division of inteliectual laboux between Academies and Univergities. So discover and to teach are distinct functions; they are also distinet gifts, and are not commonly found united in the sane person. He, too, who spends his dey in dispensing his existing knowledge to all. comers is unlicely to heve elther lelsure or energy to sequire new'. The Ides of a University, op. cit., p. xxx. That little evidence there 15 here suggests thet the skills regulyed for beaching and research are lergely independent abilities, see: B.R. Guthrie, The Vveluation of Ceaching, Seattie, Univergity of Nashington, 1954 . 
should surely abandon the research requirement rather than the teaching one. The evidence on this point is almost entirely anecdotal, but it is reasonable to point to the fact that the increasing degree of specialization required for the advancement of knowledge makes extremely heavy demands upon the time and energies of the man who is working on the frontier. He thus tends to have less time to maintain broader interests and 11 ttle inclination to explain what he is doing to undergraduates - - even supposing that they are able to make sense of his explanations. He is also likely to have less time to spend with students since his most absorbing interests lie in his research and he naturally sees this as having first claim upon his time and energies. It might also be possible to show (some of Liam Hudson's findings point in this direction ${ }^{2}$ ) that many of those who succeed in making original contributions to knowledge possess personality traits which tend to malse them unsuccessful as teachers and as persons from whom students can learn

1. I. Hudson, Contrary Imeginstions, London, Wethuen, 1966. 
informally. Of course this is all largely speculative, ${ }^{1}$ but no more so than the claim that university teachers must combine research with teaching if undergraduate education is not to be impoverished.

That teaching and research are on no account to be separated is a piece of academic folklore. That it is widely believed is further evidence of the current pre-occupation with specialization and the training of future scholars. Teachers of post-graduate students must, of course, be engaged in research if they are to train others in its techniques; but teachers of undergraduates are engaged in an educational activity and this derands qualities quite different from those required for making original contribu-

1. Perhaps this is conceding too rach. Anyone who is familiar with the universities knows how difficult it is to preserve a satisfactory balance between the incompatible demands of teaching and research: if either of these is taken really seriously then the other is bound to be neglected as far as the great majority of university teachers are concerned. They also know that there are many people in universities who, whatever their gifts as scholars, have little interest in or capacity for teaching. All too of ten these brute facts are papered over with implausible claims for the interdependence of teaching and research instead of being frankly recognized by re-allocating rewards and responsibilities. Current talk about increasing the 'productivity' of universi ty teachers may, if it does nothing else, a t least bring this issue into the open. It is, of course, a very complex and delicate business with important implications for the whole sy stem of higher education; for a hard-headed discussion of some of these implications see: $\mathbb{E}$. Robinson and $D$. Jaynes, 'Pay and the Academics', Higher Education Review, I, 39-54, 1968. 
tions to knowledge. The teacher of undergraduates must, it goes without saying, be deeply immersed in his subject and able to follow new developments in $1 t$; but he must also be able and willing to convey to students his own understandings and interests, to connect his discipline with wider intellectuel interests, and to devote the bulk of his time to teaching. These are the things that matter educationally, and he is unlikely to be able to do them justice if most of his energies are directed to quite different ends. There are a few individuals who are able to achieve outstending success in both teaching and research, but their number is much smallex than we like to think. And that there are such people does not affect my general point that success in research is not a necessaxy condition for success in teaching. This issue also connects with the view of the university as a commut ty in which all the members are working together towards the achievement of comon goals. But there are frequent complaints from students that they have too few opportunities to talk with their teachers. At a recent meeting devoted to the topic of staff-student relations the point was strongly made by students that one of their greatest disappointments with university life was that there were few occasions when they were able to discuss with their teachers ideas of wide scope and interest. they had identified university education, in part, with 
wide-ranging intellectual. conversations in which important issues of all kinds were discussed in an informed and serious manner. ${ }^{1}$ This is not an unreasonable expectation, yet they found that most of their teachers either had no time for such conversations or else lacked interest in the wider world of ideas. There is a good deal of substance to this complaint, and it is another indication of the extent to which educational concerns are being neglected in farour of activities which are often incompatible with effective teaching. There is much more to an educational programe than what can be achieved through formal teaching and the construction of a satisfactory curriculum. It is not enough for university teachers to be on top of their discipline and eager to teach 1t to others: they must also be interested in their students and recognize that they have interests and concerns which often range fax beyond what is of irmediate academic significance. Opportunities for informel conversation may be at least as important educationally as lectures

1. The existence of a comunt ty depends upon shaxed meaningful experiences.... Half an hour's quiet conversation on a topic of real concern, if repeated over time, will do more than any number of monster receptions.... the se and nany other humble acts of communication make up the academic communion for which we should strive.' P. Iinner, the Crisis of the State Universities', in N. Sandford'(ed), The American College, New York, Wiley, 1962, p.960. 
and tutorials, and if teachers are too engrossed in their own research to be able to involve themselves in such conversations then the students are being defrauded and their education impoverished.

The problem of the relation between research and teaching really turns upon the demands which are made by these two activities. Success in advancing knowledge and understanding today frequentiy requires the devotion of a great deal of time and energy to the cultivation of a very small area of a field of inquiry, and this inevitably conflicts with what is required for successful teaching in higher education. But when the concern is for the training of future scholers and epplied research workers this fits much more comfortably with engagement in research since these two activities can easily proceed hand in hand. Indeed, it is difficult to see how one can be trajned in a skill except by some form of apprentice-ship to someone who is engeged in its practice. If universities are basically centres in which knowledge is pursued for its own sake and their teaching function is primerily that of securing a succession of scholars then it seems clear that these two functions should be carried out in the same place by the same people. But if universities are also to provide higher education then conflict between this function and the other two appears unavoidable: in fact, the evidence of such 
conflict is now everywhere apparent.

Professionel training, end the epplied knowledge connected with professional practice, seems to be quite independent of the functions considered so fax. It seems obvious that these should be conducted within the one institution since the people most concerned with successful professional practice are those most likely to be interested in the theoretical problems generated by such practice and in the teaching of future professionals. But this is no reason for associating professional training and the extension of professional knowledge with either pure research or higher education, unless it can be demonstrated that more wi1. be gained from such an association than will be 10 st.1 But this has yet to be demonstrated: the universitieg have come to undertake these tasks partiy because there was no othex institution capabie of accepting responsibility for them and partly because of the high prestige which work and study in a university comanded.

1. 'What do a college and graduate school in the arts and sciences, a school of business and a law school gain by being built into common blocks of buildings? Probably it is time for educators to enact their own anti-trust law to break up tendencies to educationel concentration unless they can be shown to be necessary from the standpoint of better education'. L.S. Fener, The Nultiversity - Ideology and Reality', guadrant, IX, $43-48,1965, \mathrm{pp} .47-48$. 
Applied research directed towards the solution of practical problems sometimes arises naturally from the work of scholars and employs many of the techniques which they have developed, but this is no argument in favoux of the universities engaging in applied research. Higher education and professional training (exdept the training of research workers) have nothing in common with applied research and hence nothing to gain from being conduoted in the same institution with it. The major consequence of the universities accepting responsibility for a growing amount of applied research is that they tend to become larger and many of their staff are drawn away from their other responsibilities by the financial and other attractions of doing work for the Defence Department, the Dow Chemical Company, or the space programme. There are therefore good grounds for saying that applied research is incompatible with scholarship and higher education if these are all carried out within the same institution.

Tinally, what can be said of the university's role as a cultural centre? It is certainly in no way dependent upon applied research and professional training,

1. For some arguments, based upon Anerican experience, in favour of keeping non-educational, applied research establishments off the campus see: H.C. Johnson, 'Are our Universities Schools?' Harvard Educationel Review, XXXV, $165-177,1965$. 
nor is there any reagon to suppose that it need be juxtaposed with these in order to flourish. If the cultural function is conceived in the manner suggested by Oakeshott and Griffiths, thet is, as being at one with the task of providing an environment within which learning may be pursued for its own sake, then no problem arises: cultural centres will flourish (by definition) wherever the advancement of learning flourishes. But if the notion of 'cultural centre' is expanded in order to encompass a good deal more than what Oakeshott calls the peculiax academic engagement of explanation' then its relation to the other four functions becomes more problematical. If one of the cultural tasks of the universities is to connect explanation with action by, for example, critieizing the values and structure of the surxounding society then this will not necessarily be done by an institution which is committed only to the advancement of learning. Academic objectivity may appear to lend itself to this form of social criticism but, as was suggested in the previous chapter, it can also operate in such a way as to discourage the scholar from seeing what he does as having anything to do with changing the way things are. Nevertheless, the fundamental questioning and search for truth which characterize pure research 
are precisely what are required to provide a background for an independent appraisal both of all the elements which comprise a cultural tradition and of a current way of life; so if this type of criticism is likely to be practised at ell then we might expect to find it in universities, especially as the universities are the only social institutions we have which need not fear being closed down on account of what some of their members say.

How, then, are we to answer the question ' What are universities for? One way of arriving at an answer is to examine what universities actuelly do, but this only reveals that they have a number of functions some of which are in conflict with others. Another way of producing an answer is by developing an essentialist account along the lines proposed by Griffiths: ${ }^{1}$ this results in reducing the responsibilities of the university to pure research and the training of future scholars - with some allowance made for the provision of a rather limited form of higher education. Or we could look at the intellectual tasks whtch confront us and attempt to allocate these to various types of institution and give to the universities those tasks to

1. A.P. Griffiths, 'A Deduction of Universities', op. eit. 
which they seem most suited: having decided what we want, we then design institutions to achieve 1 . But universities are very encient institutions and it is not easy (or desirable perhaps) to change them in radical ways. Oux main difficulty is that existing institutional foms are being overtaken by events: the universities have taken too much upon themselves and are being intolexably strained as a result. It is therefore necessery to make some major decisions regarding the bost possible disposition and conjunction of the activities considered in this chapter and the preceding one; but before advancing my own proposels much more must be said about the concept of 'higher education' since it is upon this that many of them turm. So I now take up in detail the implications of construing higher education in terms of intellectual development. 
CHAPTER IV

\section{Training the Mind}

Insofar as education is thought of as a process whereby the intellect is fomed and developed, it is seen to be primarily concerned with certain cognitive skills and capacities rather than with propositional knowledge. An educated person is someone who is able to conduct his intellectual life in a distinctive manner rather than someone whose mind is well-furnished with factual information. One of the main tasks of an edueationel programme is therefore to develop in the learner those desirable 'states of mind' or 'mental quelities' which are constitutive of such a distinctive mode of intellectual life. Indeed, our basic concept of what it is to 'heve a mind' relies upon the attribution of some capacity, in however rudinentary a form, to conceptualize and to reason. ' 'Education' covers much more than cognitive development, as I shall argue in the next chapter, but no account of it which ignores intellectual development can possibly be considered adequate. Yet when we talk about the qualities of mind which education

1. See: W.C. Kneale, On Having a Mind, London, Cambridge University Press, 1962. 
serves to promote we are obliged to use terms which are aistressingly vague end very 100 sely related both to each other and to edneationel practice. 1 Almost any discussion of the function of higher eduestion in fostering such qualities in students contains such terms as 'critical thinking', 'sound judgment', 'independence', 'flexibility', 'imeginativeness', 'acuteness', 'perceptiveness', and the 1ike. Here are three 111ustrative examples from the recent

\section{1iterature:}

The student must also learn to interpret his findings and to test the validity of his inferences; he must be helped to develop the capacity to think analytically, criticelly and creatively so that he may contl nue to learn throughout his life. ?

1. "Open-mindedness", "passive" and "activen attitudes to learning, "the ert of inquiry": without such concepts 1 t would be impossible to frame any edncational polioy at all... A moment's reflection will however show that the eriteria for the application of these concepts are so numerous? diverse, and uncertain, so complicetedly and perhaps inconsistentiy related to each other, that the stetements in which the texms occur cannot be taken to have a clear and settled meaning and so cannot be regulariy confimed and refuted.' J.P. Corbett, 'Opening the lind', in D. Daiohes (ed), The Ides of a Mew University, London, Deutsch, 1964, p.37t

2. Tertiary Education in Australia, vol. 1, Report of the Comititee on the Future of lextiery Educetion in Australia to the Australian Universities Comission. Cenberra, Goverment Printer, $1964, \mathrm{p} .51$. 
[University educated people should] ... have certain traits of character, such as openness of mind, breadth of sympathy, and power of critical judgement, that are thought to be fostered by academic studies. I

[Industry needd]... good all-round men of well-developed critical ability who mould have the capability of taking part in the decision naking which managenent implies. The men must be of good charsoter, disciplined individual has 1 earned how to go on eduoating himself...

Concepts such as these have traditionally been associated with a theory of mental operations which posits a high level of generality for the central powers of the mind. This doctrine has played an important part in theories about the nature of university education in that it has formed one of the bases for the view that it is one of the prime functions of the universities to produce people who possess 'trained minds'. I shall first examine this doctrine and then analyze some of the more important 'mental conduct epi thets which are commonly used in such a way as to pre-suppose its truth. This will enable us to determine what is meant when people speak of higher education as being the provision of intellectual training.

1. Report of the Committee on the Structure of the First and Second Public Exarinations, Oxford, op. cit., p.26.

2. D.C. Johnson, 'New Bradford Course Prepares Students for Industry', Imes Sducational. Surplement, 13 September $1968, p .439$. quoted from Universities and Industry, Confederation of British Industries, 1967. 
Generality and Intellect

The notion of 'the well-trained mind' is a legacy of feculty psychology: it amounts to the view that

intellectual skills are of such a general character that they enable their possessor to apply himself to any subject-matter whatever. Although facul ty psychology has long-since been discredited the idea that a university education equips a man with akills which can be applied over a very wide range of problems is still an important part of academic folklore. It continues to find expression in the practice of appointing distinguished academics to commissions of inquiry, a practice which is justified by a belief in their ability to bring 'trained minds' to bear upon the subject undex review

1. A concise statement of the doctrine was made by E.I. thorndike: The common view is that words like accuracy, quickness, discrimination, memory, observation, attention, concentration, judgment, reasoning, etc., stand for some real and elementary abilities which are the same no matter what material they work upon; thet these elementary abilities are altered by special discipline to a large extent; that they retain these alterations when tumed to other fields; that thus in a more or less my stexious way learning to do one thing well will make one do better things that in concrete appearance have absolutely no community with it.' Educational Psycholoey, New York, Lemcke \& Buechner, $1903, \mathrm{p} .84$. For arguments to support the claim that the concept' transfer of trainin' should be totelly abandoned by educational theorists, see: E.I. Kelly, Iransfer of Training: an Analytic Study', in B.P. Komisar and C.J.B. Macmillan (eds), Bsychological Concepts in Rducrtion, Chicrgo, Rand MoNally, 1967. 
notwithstanding their almost total ignorance of $1 t^{1}$ It may well be that the long-standing British penchant for the amateur in government, politics and administration is founded upon a belief in the capacity of the man wi th a 'trained mind, to cope successfully with any task regardless of his lack of knowledge concerning it. That such a view is still powerfully at work in educational theorizing is evident in the following passage:

The effect of Iiterae Humaniores on its students is to develop thought and speech and a keen and critical intellect. It is deficient in providing knowledge of the modern world, and history and economios will remain a closed book uniess the student, as of ten indeed happens, makes himself well infomed by his own efforts and intelligent general reading. But it is sald to produce men who are unxivalied as expositors and judges of any situation or set of facts placed before them. 2 Al though there is some substance in the doctrine of 'the trained mind' 1 ts inedequacies are such that it will

1. Sir Edward Hale has given an account of his reflections upon being appointed chaiman of the Committee on University Ceaching llethods. After referring to Bishop Watson's candid adnission of his ignorance of the subject after being appointed to the chair of chemistry at Cambriage in 1764 , he remarks: 'As I read this it seemed to me that my situation was very gimilar to that of Bishop Watson, It was similar not only in ny totel i morance of the subject which I was appointed to study but al so in the kindness with which I was treated by the univerofties.' The Report of the Committee on University Teaching Methods', Home Universities Conference The Listener, 10 September 1964.

2. J.L. Brierly and H.V. Hodson, 'Ii terae Humaniores', in the Ilandbook to the University of Oxford, 1962, Iondon, oxford University Jress, 1962, PD. 149-150. 
not do the work which its adherents wish upon it, Perhaps its najor weakness steng from a fallure to recognize that intellectual skills and abilities, like physical skills, are very closely bound up with particulars: ${ }^{2}$ with a certain type of problem, with individuel questions of fact, with axgunents of a distinctive character, with one field of inquiry. A man knowing nothing of mathematios cannot solve a quadratic equation simply by inspection. He needs first to be able to identify it as an example of a quadratic equation before he can even begin attempting to make the moves appropriate to its solution. It might be objected that what is meant by having a 'trained mind' is not that its owner is able to solve any particuler problem such as an equation but rather that he is equipped with a number of skills without which he would be unable to deal with any problem. Ixamples of such pre-suppositional skills might be: the ability to identify a problem, knowing what counts as relevant evidence, skill in deploying valid rather than fallacious argunents, capacity to see the force of criticism, and so on. These

1. A point which is made by a psycho-therapist in one of John Barth's novels. "The authors of medical textbooks," he added with some contempt, "like everyone else, can reach generality only by ignoring enough particularity. They speak of paralysis, and the treatment of paralytics, as though one read the textbook and then followed the rules for getting paralyzed propexiy. There is no such thing as paralysis, Jacob. There is only paralyzed Jacob Horner".' The bnd of the Road, Hamondsworth, Hiddlesex, Penguin Books, $1967,2.79$. 
could all be viewed, in a sense, as formal considerations: that is to say, as being lergely field-independent and disconnected from particular matters of substance. If this were so then thelr formality would guorantee extensive generality. But, apart from those which depend upon purely logical considerations, this is not a cleim which can be made out in any detail.

Consider one very importent skill which migivt be supposed to possess very wide applicability, namely, the ability to axgue. Arguments can be strong, weak, decisive, plausibie, dubious, convinoing, fallacious, and so on; we acoord particular arguments these descriptions in the light of standards or criteria which are of high generality only to the extent to which they relate to the formal properties of arguments. In this way we might say that foxmal validity is a necessary condition for the soundness of and argument. But to say this is not to edvance matters vexy fax since arguing, like conversation, is a high axt rather than a rulefollowing activity. Arguments are not genesated simply by following rules: a demonstrated knowledge of formal logic is no guarantee whatevex of a capacity to develop and deploy good arguments, for in order to be able to do this it is also necessary to know a good deal about the subject matter of the argument. To be able to argue about problematic questions in mathematics, philosophy and history one needs 
not only to know something about such questions but also to be faniliar wi th the ways in which they are handled, and these are all, in important respects, heavily field-dependent. Suppose that we wished to discover whether a man was skilled in axgument. It would not do simply to issue the command 'Commence arguing!' If this were done then the exaninee would be bound to ask. what it was that we wanted him to srgue about. If we then stipulated, say, the authenticity of the Codex Vaticanus', then he might well reply that he knew nothing whatever about it and was thus incompetent to discuss the problem. Or suppose that after solving a problem or concluding an axgument the examinee were to be told that he had misunderstood his instructions: he had been required not to solve the problem or to argue ebout it but simply to demonstrate that he poseessed the appropriate skills. In such a case he would surely be correct in objecting that he had been given an impossibie and, indeed, meaningless task.

Arguments are flavoured by the field of discourse in which they are employed and out of which they have developed. Legal, moral, political, mathematical and philosophical arguments can be distinguished one from another but these distinotions do not rest upon differences between the formal features of the arguments because these, 
if anything, are what they shere in common. What

individuates various broad classes of arguments is their 'flavour', and by this I mean the circumstences in which problematical is ues arise, the characteristic concepts which figure in them, the kind of evidence wich is taken to be relevant, the strategens which are permissible and the considerations which neke sone noves decisive. In order to appreciate this Mavour and, a fortiori, to be able to engage in argument with sonle degree of skil1, one needs to get the feel of a subject, to become sufficiently familiar with 1ts factual, logicel and procedural terrain to be able to move over it with some confidence and to follow the novements of others with ease. Mithout some degree of faniliarity with what the whole business is about there is Iittle prospect of being able to see the point of what more skilful people are dolng. It is scarcely surprizing that one's early excursions into theoretical territory which is unfamiliar should produce feelings of bafflement since it takes some time before the novice can begin to see what the problems are and why some ways of denling with them are preferable to others.

This is equally true of the learning of such practical skills as flying, ship-hending and surgery. One cannot teach these by means of repeating such injunetions as 'Be careful!' or 'Be vigilant!' or 'Maintain a constant 
look-outl' The learner needs to know what it is that he must take care over or what it is that be must look for. He cannot simply exercize care, vigilanee or attention: he must attend to something. The learnex bost-handlex, for example, needs to be told to keep a watch for other vessels so that avoiaing action oan be taken, to detect signs of curcents and oross-winds which threaten to carry the boat off course, to avoid floating timber, to malce frequent notes of the compass bearing and other instrument readings. Ixercizing vigilance and cere is cimply the general description given to an activity which satisfies all these detailed requirements and the deteils will clearly vary mexicedly according to whethex the skills are those of a helmsmen, pilot or surgeon. There is no such general slitil as 'vigilanoe' or 'earefulness'; there is only the doing of certain things in a certain manner and these can only be generalized to the exient that succeeding situations resemble those in which the skilful woy of soting was learnt. Then novel problems are encountered there is once agsin the difricul ty of lenowing just what it is about them that demands the exercize of vigilence and attention since vigilance can only be defined by giving sone content to the actions which should be consequent upon giving attention to whatever one is supposed to be doing.

Mental-conduct epithets such as 'careful', 
'vigilant', 'attentive', 'accurate' and 'thorough' are without meaning until the details of their application are filled in and it follows from this that they will be fielddependent and of very low generality. There is no such animal as 'careful man': there are just men who do particular things in partiouler ways and $i t$ is al ways necessary to specify these in some detail if we are to understand. what is meant by 'carefur surgery' or 'careful driving'.

\section{A helpful way of viewing these specifications}

has recently been sugsested by Hyle in his conte llemorial Decture in which he was conoerned with giving an account of the '... almost professional notion of thought, as a separate, self-noving and self-piloting activity of reflection, requiring some specialist training and governed by standards of its own'. He proposes that intellecturl work which fits this deseription may be said to possess a discipline or batters of aisciplines but he rejects the view that there is only one type of error which the thinikex needs to be cereful to avoid, namely, the comission of fomel fallacies, As he correctly points out, in disputes between specialists

1. This is not the case with some term shich feature in very general deseriptions of character. If a man is described as 'punctual', for example, it makes no sense to ast

'In what respects?'

2. G. Rle, Allational Mnimel, London, Athlone Rress, 1962 , p.13. 
there are rarely allegations of fallacious reasoning in any formal sense. ${ }^{1}$ Controversy usually centres around the exercige of what Ryle oplls 'scruples': the skills and procedures which are peculiar to a particular field of inquiry. That distinguishes thinicers in these verious fields is the nature of their geruples rather than their capacity for fomal reasoning. Though equally vigilant against fellacy, they also take quite different sorts of preoautions against quite different sorts of mistakes, mudiles and onissions'. 2 As examples of the kinds of precautions which a thinker might take when exereizing his 'scruples' Ryle mentions the following:

A person's thinking is subject to disciplines if, for example, he systematically takes precautions against personal bias, tries to improve the orderliness or clarity of his theory, checks his references, his dates or his celculations, listens attentively to his critics, hunts industriously for exceptions to his generalizations, deletes anbiguous, vague or metaphorical expressions from the sinews of his arguments, and so on indefinitely. 3

It might be objected that almost all of these examples are in fact cases of highly generel sixills which

1. See, for example, the exchanges between Palmer and Boardnan regarding the decipherment of the Knossos tablets in the correspondence columing of the Listener, 10 November 1960 , et seg.

2. Ryle, op. cit., p.21.

3. Ibid,, 2.22 . 
apply to every field of intellectual endeavour. Ivery author, regardiess of the subject about which he is writing, should check his references, delete ambiguous expressions, attempt to secure an orderly presentation and listen attentively to his critics. It might be said thet these are not scruples which an historian needs to exeroize but which a chemist or botanist can afford to neglect. This is true if esch of them is writing a book, but largely false of their activities as scholans. what they do when working at their specialized tasks as histoxians, botenistis, and so on, can only be appraised in terms of oriteria which are heavily field-dependent.

I eannot eriticize or evaluate the orderiliness or clarity of a theory propounded by someone else unless I have some understanding of what the theory is about (what it means) and of the oriteria governing the application of such appraisal.s as 'orderly' and' 'clear'. Understanding takes priority since without this I an in no position to judge whether the theory has been presented in a clear and orderly fashion. If I, knowing nothing about number theory, attend a conference of number theorists then I will be unable to evaluate the worth of the views which are put forward and a fortiori be incapable of judging whethex they have been put forward clearly or confusedIy. An expert might say that a particular paper contained some very interesting and 
originel ideas but that these were bady presented, but I would not be competent to make judgments in either of these categories. Similarly with dates, references and calculations: unless I know something about the field to which these relate I will not even be able to notice errors let alone be able to say how they should be corrected. The ability to evaluate the thinking of dother persons thus requires a good deal of knowledge of what it is that they are thinking about in addition to the capacity to deploy the same intellectual slilis.

If this is correct then the view expressed in the following passage is a quite preposterous one:

I must trust the advice of my doctor, my plumber, my lawyer, my radio repaimen, and so on. Therefore I am in peculiar need of a kind of sagacity by which to distinguish the expert from the quack, and the better from the worse expert. From this point of view, the aim of general education may be defined as that of providing the broad critical sense by which to recognize competence in any field. William James sald that an educated man knows a good man when he sees one. There are standards and a style for every type of activity -manual, athletic, intellectual, or artistic; and the educated man should be one who can tell sound from shoddy work in a field outside his own. 1

This is an excellent example of some of the absurd consequences of the 'trained mind' doctrine. Tife would be very much easier if the doctrine were true since we could doubtless all make good use of 'a kind of sagacity'

1. General Education in a Free Society, Report of the Harvard Committee, London, Oxford University Press, 1946, p.54. 
which enabled us to distinguish various degrees of expertness in our doctors and plumbers while remaining entirely unacquainted with the skills and knowledge possessed by them. Unfortunately, such short-cuts to wisdom are not available to us. Even within the four broad classes of activities which are distinguished in the passage quoted above, there are such varieties of standards and skills to be found that it is highly misleading to unify them under one broad label: an acknowledged expert in judging the excellencies of swimers would not, ipso facto, be qualified to judge judo contests. Similarly with intellectual exercizes; one needs to know a good deal about the activities of astronomers, historians and philosophers before one can evaluate their work. Unless one has a good grasp of a particular field of inquiry it is quite impossible to distinguish 'sound from shoddy work' in it. If experts can be deceived by bogus work ${ }^{2}$ then there is little prospect of the layman being able to distinguish between the competent and the incompetent, the true and the false, the elegant and the inelegant, the imaginative and the pedestrian. These qualities do not stand revealed to

1. See, for example, the evidence given by Senator H.H. Humphrey regarding the bogus research and publications of Dr Kathleen Roberts who worked in a number of leading U.S. medical schools and published widely in respected journals. Hearings before the Sub-committee on Re-organization of Government Printing of ice, 1965. 
all who can read: their appreciation is only open to those who have advanced some distance into a distinctive mode of thought, who have some knowledge of the relevant matters of fact, who understand the criteria which govern sound thinking in the field and who have developed a measure of competence in the intellectual skills for which it calls. There is no capacity or skill called 'broad critical sense' which will enable a thinker to avoid the trouble of acquiring these varied abilities: If he wishes to criticize the theories or arguments advanced by another thinker then he has, as we say, to 'know what he is talking about'. 1

There is, however, something to be said for the generality doctrine to the extent that it is possible for someone knowing nothing about, say, the Knossos tablets, to read a contentious treatise dealing with their interpretation with a view to discovering inconsistencies, non sequiturs,

1. The ability to develop theories rather than to criticize those advanced by others equally depends upon knowledge and experience. As Liam Hudson has pointed out, when a scientist, for example, engages in research '... he exercises skilis of a complexity greater than we can readily comprehend. And these intellectual operations are beyond us not simply because they are too complex. They depend, firstly, on huge accumulations of experience; and secondly, upon the fact that the individual concerned cares intensely about what he is doing. Without training and experience, these complex skills do not exist.' Contrary Imaginations, London, Nethuen, 1966, p.109. 
and so on. But the value of such an exercize would be extremely limited and 1 ts point obscure. To evaluate such a work would require considerable knowledge of the relevant matters of fact and of the whole mode of discourse in which they are embedded and from which they derive their significance. Anyone unfamiliax with the field would be Insensitive to its flavour and hence incapable of judging the defects or excellencies of particular arguments and theories which might be developed within it. Skill in formal reasoning is of little help here since the properties of the discourse in which a critic is interested are not open to inspection in the same way as are the properties of formal. arguments: their appreciation requires prolonged immersion in a whole way of thought in order to bring about a familiarity with the distinctive matters of fact, strategies, problems, standards and procedures which characterize it as a mode of understanding and investigation. One of the major defects of the generalizability doctrine is that it overlooks the context-bound character of intellectual skills and insists upon viewing them as being on all fours with a skill such as proof-reading which requires only that the practitioner be able to read with vigilance and 
attention.

\section{1}

Is there nothing whatever to be said in favour of the doctrine of 'the trained mind' beyond allowing wide generality to the skills involved in formal reasoning? A skill which is often quoted as an example in support of the doctrine is that of 'knowing how to get up a subject?. ${ }^{2}$ This is usually thought of as a method of intellectual attack which is so general that it can be applied to any subjectmatter whatever. There is a good account of what is commonly meant by it in Leonard Woolf's autobiography:

I heve often irritated people by saying that an intelligent person can become what is called an 'authority' on most 'questions', 'problems', or 'subjects' by intensive study for two or three months. They thought me arrogant for saying so, or, if not arrogant, not serious. But it is true. The number and volume of relevant facts on any subject are not many or great and the number of good or important

1. The kinds of mistakes for which proof-readers search do not require knowledge of the subject-natter for their detection, whereas the errors which scholars note do. A recent review contained the following sentence: 'There is even so astonishing a howler as "llarx's concept of alienation emerged from his analysis of nineteenth century England". If I had read the book, knowing nothing about Marx or nineteenth century England, then it would have been quite impossible for me to have noticed such a howler - let alone to have been astonished by it.

2. 'I.remember almost nothing of the factual content of what I learned at Oxford: nevertheless I am quite clear that it was of enormous and enduring value to me in teaching me how to get up a subject, how to think elearly for myself, and how to use language to communicate my thoughts'. Six Edward Hale, Home Universities Conperence 1964, pp. 16-17. 
books on it are few. If you have a nose for relevant facts and the traits which lead to them -- this is essential and half the battle - and if you know how to work with the laborious pertinacity of a mole and a beaver, you can acquire in a few months all the knowledge neeessary for a thorough understanding of the subject. 1

With a number of reservations, I am inolined to accept this. Woolf is not really claiming very moh, only thet it is possible for intelisgent people who know how to make use of a good library to acquire a limited 'grasp' of a subject provided that this can be gained via the printed word. He is not saying that the use of such a method will enable the learner to make original contributions to the subject or to arrive at a full understanding of it, but only that he will gain a reasonable conception of what it is all about. His use of the term 'authority' is thus misleading for it suggests a level of expertise which would clearly be unattainable in a few months unless the subject is one of a very limited character. It is clear from his reference to particular 'problems' and 'questions' with their 'relevant facts' that what he has in mind is subjects of very restricted scope concerning which it would make pexfectly good sense to speak of mastering the relevant body of facts. Examples of such topics would be the following: the fussoFinnish war, the 1956 suez crisis, the development of the

1. I. Woolf, Beginning Again, London, Hogarth Press, 1964, p.185. 
Zeppelin, the pruning of fruit trees, the principles of dietetieg or home wine-making. These are all subjects which could undoubtedly be 'got up' in two or three months for even weeks) by diligent use of the resources of a public library. But one would not get very far with mathematics, history, philosophy, physies or the history of art by using the same approach over the same period of time since in such complex fields as these not only are the relevant bodies of facts very much more extensive but they are also, in an important sense, of lesser significance. ${ }^{1}$ For in these subjects, as in life generally,,.. we are much more concerned with people's competencies than with their cognitive repetoires, with the operations than with the truths which they learn'.? What, then, remains of the doctrine of 'the trained mind'? Not very much. It relied upon a view of the mind as comprizing a collection of unitary abilities which could cut across any and every subject and which could be developed by studying any one of them; such a view of intellectual operations can no longer be accepted since it

1. On an occasion in the nineteen-twenties when lindemann was deploring the low status of seience at oxford the wife of the Warden of All Souls told him: "You need not worry, a man who has got a First in Greats could get up science in a fortnight.' R.F. Harrod, The Prof, London, Namillan, 1959, p. 53 .

2. G. Ryle, The Concept of the Mind, London, Hutchinson, $1949, p .28$. 
requires us to apply unifying conceptual labels to activities which are markedly different. ${ }^{1}$ All that can be salvaged from the old doctrine are the skills of formal reasoning which are genuinely field-independent because they are uncontaminated by questions of fact, and a few procedures such as the one discussed above. But neither of these will get the learner very far in exploring a particular mode of understanding and. in conjunction they will not do the work of the old doctrine. Assesments of intellectual competence typically make use of such terms as 'critical thinking', 'judgment', 'creative' and 'independent': these will now be examined in order to determine the range of their application and their value for an account of higher education in terms of cognitive development.

\section{Critical Thiniking}

What is it that distinguishes 'criticel thinking' from other types of thinlcing? Calculating, driving, composing, tennis-playing, translating, planning a holiday, listening to a lecture, daydreaming -- these very diverse activities all require thought yet which of them, if any,

1. For discussion of this point see P.H. Hirst, 'Liberal Education and the Nature of Knowledge', in R.D. Archambault (ed), Philosophical Analysis and Education, London, Routledge, 1965. 
involve 'eritical thinting'? Daydreaming looks to be an obvious non-sterter for al though it undoubtedly involves thought it falls outside that brosd category of 'professional thinking' distinguished by Ryle. It does not require the thinker to attend to what he is doing since he is not doing anything in the sense of being engeged upon a task which he has deliberately undertaken. Deydreaming is a state into which one falls unsuspectingly, unwittingly and unintentionally. Daydreans and reveries are 'happenings' rather than the consequences of intentions and decisions. One could certainly deliberately pretend to be daydreaming but once in a state of reverie one could not pretend either to be in that state or not to be in it. If I wish to overhear a conversation which is being conducted nearby and believe that the participants will be less likely to lower their voices if I appear not to be listening then I might decide to simulate a state of daydreaming. But if I am genuinely in reverie then this excludes the possibility of my being able to attend to what they are saying. Daydreaming, in contrast to pretending to be daydreaming, is not the kind of activity to which one can give attention, concentrate upon, work hard at, try to do well or fail to get right. It is rather like the physical processes of digesting and ageing in that it simply happens and allows no scope for competencies. As Ryle has pointed out: 
A man in a daydream is thinking, but he is not thinking hara, efficiently, rigorously or successfully: nor yet is he daydreaming inefficiently, loosely, carelessly or unsuccessfully. He is not navigating well or badly: he is just drifting. 1

\section{Listening to a lecture, however, is a very}

different kind of activity from daydreaming. It involves attending to what is being said, trying to follow the argument, relating whatever is being said to one's existing lknowledge, and being on the alert for illuminating remarks, new insights into a problem, well-founded conolusions, exrors of fact, faulty reasoning, witticisms, and the like. Unlike daydreaming, listening to a lecture is an activity which allows scope for competencies and hence for success or failure. But does it afford scope for such a competency as 'eritical thinking'?

Exercizing care, as I have argued earlier, means much more than simply attending to whatever is going on: it requires the thinker to be on the look-out for certain features of the situation in order to be in a position to react to them in an appropriate anner -- in this case 'critically'. To think critically about something is to assess it in the light of standards or criteria, and to engege in this type of thinking one must not only know what

1. G. Pyle, 'Thiniking', Acta Psychologica, IX, 190-196, $1953, \mathrm{pp} .195-6$. 
the relevant oriteria are but also be concerned to use them in appraising. It is not enough to be familiar with the criteria in the sense of being able to recite then: the thinker must be committed to employing them in the evaluation of his own performances and those of other people. He must care about the standards as well as know what they are, and the evidence that he does care will be displayed in the ways in which he attempts to improve his own perfomences and the comments which he makes upon the performances of others.

Thinking of this kind could be called for in all activities which involve the exercize of skill, since to do sonething skilfully is to do it in accordance with standards or canons. Even skills capable of being converted into habits and routines demand critical attention while they are being learnt. Te soon master the simple skills of tying our shoe-laces or knotting our ties, yet we would be unable to succeed even with such straight-forward tasks as these unless we were able to appreciate that there were correct and incorrect ways of carrying them out and to adjust our performances in their light.

But this is not the kind of critical activity which educators have in mind when they speak of 'critical thinking', for a person could give evidence of this kind of thinking wi thout being in any way imbued with the 'critical spirit'. The 'critical spirit' is much more like an attitude 
than a skill: it is manifested in a willingness not just to evaluate the extent to which a skilled performance measures up to standard, but al so to question these standards - and even to ask whether the activity itself is one which is worth doing. 1

To say that 'critical thinking' is to be classified as an intellectual character trait rather than as a slill is to admit that we can in fact identify traits of mind which are, in some sense, of a highly general nature. Is this consistent with the conelusions of the previous section? We do not hesitate, when providing character references or discussing the personal qualities required of applicants for a job, to describe people as being punctual,

1. The competent teacher will rightly demand from his pupils a high standard of performance in the sicilis he is teaching: he will be hostile to shoddiness, leziness, contented mediocrity. But in teaching his pupils skills at a high standard, or in encouraging then to examine critically their own performances and the performances of their fellowpupils, the teacher is not, I have suggested, automatically engendering in them a critical spirit, as distinct from the capacity to be critical of certain types of specialized performance. For to exhibit a critical spixit one must be alert to the possibility that the established norms themselves ought to be rejected, that the rules ought to be changed, the criteria used in judging performances modified. Or perhaps that the mode of performance ought not to take place at all'. J. Passmore, 'On Teaching to be Oritical', in R.S. Peters (ed), The Concept of Education, London, Routledge, 1967, p.197. 
polite, kindly, industrious, honest, conscientious, responsible, resourceful, even-tempered, out-spoken, and the like. These might all be proffered in answer to the question 'That kina of person is he?' Unless these tems were qualified in some way they would all be taken to be of general application, that is, as describing behaviour over a very wide range of situations. Whenever the individual concerned is asked to do a particular job he works hard at it, whenever he is in a position of trust his honesty may be relied upon, when tempers tend to become frayed he usually manages to keep his under control, and so on. It would be odd to ask in what respects a person was punotual, industrious, polite or kindly, whereas we would be obliged to asts in what respects a candidate was skilful, experienced or well-trained.

But what if we are asked to supply an

'intellectual character reference'? Should the adjectives likely to appear in this be classified in the same category as 'Isinaly' or would they be more at home beside 'sirilful' and 'well-trained'? An intellectual character reference would presumebly attempt a description of a candidate's 'qualities of mind', that is, the characteristic ways in which he tackles intellectual tasics, and would thus include such adjectives as: lively, acute, penetrating, critical, 
flexible, creative, judicious, independent and sharp. These do not refer to particuler skills but rather to the manner in which a man conducts his thinking whenever he is seriously trying to get something right. What, then, is the objection to seying thet such adjectives as these cen be used to provide a general description of an individual's intellectual competence? What grounds are there for distinguishing them from such epithets as 'kindly', 'honest' and 'considerate' which are undeniably of high generality?

Perhaps the most obvious basis for making such a distinction lies in the connection between 'qualities of mind' and 'knowing'. 1 To sey that a man is honest, reliable, industrious and considerate is not to ascribe to him particular knowledge or skills; it is simply to claim that, in general, these are accurate descriptions of the ways in which he behaves -- he is 'that kind of a person'. But to say that someone has a 'mind' which is critical, judicious or penetrating is to be comitted to saying that he knows how to do something as well as, quite commonly, that he imows

1. 'At least an important part of what we mean by "intellectual powers" is those specific capacities which are originally inculcated and developed by didactic discourse.... Didactic discourse is the vehicle for the transmission of knowledge'. G. Byle, the Concept of Mind, London, Hutchinson, $1949, \mathrm{p} .309$. 
that a great many things are the case. The untutored savage can be honest, kindIy and industrious, but he cannot be said to have a mind which is critical, flexible and judicious since these qualities can only be displayed in the manner in which he conducts his specialized intellectual performances and, ex hypothesi, he is in no position to engage in such performances. He cannot simply 'be critical': he must be familiar with the stendards of appraisal which are appropriate to different kinds of performance as well as be able to apply these to particular performances. ${ }^{1}$

It will not do, therefore, to give an account of what is involved in 'being critical' solely in terms of an attitule, for a critical person is not one who adopts a particular mental stance or posture. If I am to attempt to evaluate a theory, play, exgument, book or perfomance I must both know something about it and be familiax wi th the standards of excellence which are appropriate to it. It is not enough for me simply to entertain a critical attitude towerds whatever is subject to appraisal; indeed, it is difficult to understand what this could mean. The growtin of a critical attitude is logically dependent upon knowleảge

1. This is too condescending: primitive peoples have their own standards for appraising both practical skcils and the public and private conduct of life. See: C. Levi-Strauss, the Savage Mind, London, Weidenfeld \& Nicolson, 1966. 
and understanding in a way that honesty, kindliness and industriousness are not. One of the things wrong with the doctrine of the trained mind is that it encourages us to suppose that the features of intellectual work which we label 'oritical', 'flexible', 'judicious', and so on, are slills which, once developed, are capable of being applied to whatever tasks may happen to come along. The view for which I am arguing construes such terms as being closely tied to perticular bodies of knowledge, families of skills and modes of understending. Their generality is thus of a much lower order than that possessed by the field-independent biographers' adjectives such as 'kindly', 'good-tempered', 'humorous' and 'ambitious'.

If we are told that a man is ambitious this tells us nothing about what he will actually do in particular circumstances, it only licenses us to infer that whatever he does is likely to be shaped by his desire to secure preferment. We are thus given an extremely general account of his actions and propensities. But if we are told that he has a critical or judicious mind this is completely uninformative unless we know in what respects he is competent to make eritieisms and judgments, for we do not attach any significance to someone's capacity simply to exy 'I question that!' whenever a statement is mede; or to judge paintings to be good, calculations to be correct or arguments to be 
valid, 'off the top of his head' as we say. People do not have or lack 'critical minds', but they may well be able to handle specielized classes of problems or deploy families of sylis in a 'critical manner', that is, by attending closely to what they are doing in order to correct their mistakes in the light of standerds of correctness. And the kinds of things towards which their attention will need to be directed and the standards governing success will vary enormously according to the activity in which they are engeged. Critical thinking thus requires the thinker to learn the moves, strategies, standards, skills and factual knowledge appropriate to particular activities if he wishes to evaluate the performances of others and to gain some degree of competency for himself, and the knowledge and skills required will be as varied as are the activities in which historians, rose-growers, philosophers, pilots, surgeons and composers engage.

Yet there is a sense in which we might describe someone as 'criticel' and be intending to offer information about him which would be on all fours with such descriptions as 'honest', 'dependable' and 'punctual'. Such a description would amount to a shorthand way of saying thet he is always, or almost always, or characteristically, reluetant to accept what others say at its face value, suspicious of dogmatic and authoritarian pronouncements, sceptical where others are 
too readily convinced and willing to question matters which many take to be bejond dispute. ${ }^{1}$ But this general axitical attitude needs to be distinguighed from the specialized critical activity which should be a part of all intellectual work and which is closely tied to particular complexes of knowledge, skilis and standerds. This distinotion is often obscured by loose talk about critical thinking being a habit: many people speak of encouraging students to think critically much as they might urge them to clean their teeth regulariy. There is little harm in this if they are thinicing of 'critical' as being an item in a man's character inventory, but it is highly misleading to conceive of his activities as a thinker in this fashion. If by 'oritical' we mean a regular tendency or disposition to be sceptical and inspect the credentials of what others sey and do then it is not unreasonable to treat this as a habit; but if we imply that the manner in which a thinker goes about his intellectual. tasks is habitual in character then this would be inconsistent with describing what he does as 'oritical thinicing'.

1. 'At the university, the critical faculty must be developed by a refusel to dogmatize or accept dogmatic judgements irs any matter of pure criticism. The teacher, whether in lecture or serinar, must be continually questioning and systematically presenting both sides of every debatable question. It takes a long time to get one's pupils into this habit and many of them never get into it at all: of these last 1 t must be regretrully seid that they have received university instruction but failed to get a university education'. B. Truscot, Red Brick University, Iondon, Faber, 1943, p.142. 
The advertisements of the Ranle Orgenization used to feature the injunetion 'Get the Odeon hablti" and the object of this wab to pexsuade people to attend theis olnetas regulaxiy regardiess of the films which were beting shown but if the patrone exercized theix oxtioel powers then this would not be conglatent with habituel attendance at the oinema. It woul a clearly have been most unwise of the Ranit management to have invited people to thint eritically about the fllms which were shown since the profttability of their buatness depended upon a suffictently large number of people acquiring the habit of attenaing the cinema every week.

Then we desoribe behaviour as being 'hobituel. we are indicating its regularity: habits are predictable, stable and unvarying elexents in an agent's behaviourel repetoire. This usage unableg us to place in the saas category such alesimilar activities as teeth-cleaning, amolutag, looking to the 1 elt and 1 ight berore orossing a road, and counting one's change 12 shops, But these axe all actiona which maike minimal demanis upon the agent's intelizectual. powers: they are responses to dituations for regular forms of beheviour) which oan be zun through in a woutsne and unexacting manner - we cen usually do them 'wh thout thiniling'. But exitieal thincting clearly cannot be a habit in this sense simce it is calied for 1 situstons 
which tax to the full the thinker's powers of attention, memory and reasoning: one may be said to habitually (characteristically) think in this manner, but the elements which oonstitute the manner cannot thenselves be described as habits. This is because they are exercized in situations which demand flair, alertneas, imagination, insight, flexibility and strategical resourcefulness - all qualities for which habits offer no scope whatever.

\section{Judgment}

\section{It is often said that one of the aims of}

university education is to produce students who are capable of making 'good' or 'sound' Judgments. It is not at all clear whether this refers to a capacity which can be defined Independently of 'critical thinluing', so I shall simply try to show that even if it is so defined it will still remain heavily field-dependent.

To make a judgment is to come to a decision about the extent to which whatever is being evaluated meets eertain criteria. If a man is described as a good judge of horses then this implies that he knows a good deal about horses, is familiar with the criteria governing excellence in horses,

1. That they [the universities] have aultivated and valued most hi ghly is neither technical expertise nor prodigious learning but, as Newman puts it, the quality of judgment or the power to grapple with any subject and to seize the strong point in it. W. Moberly, The Crisis in the University, op. cit., p.35. 
and is able to apply these standords to perticular cases. Tnowledge of standards is 10 gically discomected from the capacity to judge the extent to which a partioular case measures up to then. I may have learnt that a 'good' horse should have, say, a deep chest and large fetlocks, Jet even if these are two of the criteria of excellence in horses I could well be quite incapable of applying them since I know nothing else about horses and have no $i$ dea what the tems 'deep chest' and 'fetlock' mean. I am thus in no position to judge whether any given horse has these properties or not. similarly, I could know all that there is to know about horses in the sense of being able to identify correctly their various parts and yet be quite ignorant of what distinguishes a good horse from a poor one.

\section{Al though these two kinds of knowledge are}

independent with respect to each othex, both are required if any claim to be able to make correct judgments is to be made out. A man could, of course, guess correctly when trying to aistinguish between horses but even if he were to be regularly successful in doing this we would be obliged to attribute his success to chance since he would be unable to give reasons for his judgments. And if he has no grounds for his judgments it would not be within his power to teach others to do what he is able to do. His success would remain completely mysterious and unexplained and thus be of 
no educational interest. It seems doubtful whether such judgments would possess any othex kind of interest either, sinee there mould be little point in people being able to make mysterious oracular pronouncements of this kind. If someone says that a horse, poem, performance, argument or chess move is 'good' we comonly wish to know in what respects it is good, what features of it have led him to arrive at this evaluation of 1t. Simply to pronounce that something is good, correct, plaugible, convincing, well-executed or valid and to refuse to disclose the grounds -- or even to deny that there are any -- for such judgments is to close the door upon any possibility of argument or discussion. Not only would teaching be ruled out but so would leaming how to judge one's own performances and those of others. Oracular pronouncements of this kind would, in fect, be quite meaningless.

If such a case occurred we would probably deny that it could properly be described as one in which judgment was being exexcized: we would have to dismiss it as lucley guess-work. It would, perbaps, be rather like malting judgments of distance and speed: these do not involve knowledge or skills and they cannot be taught. ${ }^{1}$ We often say that a

1. 2sychological research suggests that these abilities also

'... are probably quite specific to the type of material being judged.' D.II. Johnson, The Psychology of Thought and Judgment, New York, Herper, 1955, p.421. 
cricketer has a 'good eye' for the ball but we do not expect him to be able to explain how he 1 s able to malce the judgments he does. It would be very odd to ask a fieldaman who has just made a catch how he knew that the ball. was going to land where it did. Perceptual. judgments of this kind seem to derive partly from native endownent and partly from experience, but the relation between the experience and the judgnents is, as in the case of judging charactex, obsoure. ${ }^{1}$ What is elear, however, is that the capacity to make judgments requires knowledge and experience relevant to whatever is being judged and will therefore have little application outside the field in which it is acquired and practised. As Wittgenstein pointed out, those who are able to make good judgments of the feelings of other people will generally be those who have a 'better knowledge of man'cind'. A man may well be allowed to be an excellent judge of horses yet be quite incompetent to judge of the excellencies of

1. 'Is there such a thing as "expert judgment" about the genuineness of expressions of feeling? - Even here, there are those whose judgment is "better" and those whose judgment is "worse". Correcter prognoses will generally issue from the judgments of those with better knowledge of mankind. Can one learn this knowledge? Yes, some can. Not, however, by talding a course in it, but through "experience". - Can someone else be $a$ man's teacher in this? Certainly. Trom time to time he gives him the right tip. - This is what "learning" and "teaching" are like here. - - That one acquires here is not a techniaue; one learns correct judgments. I . Wittgenstein, philosophicsl Investigations, Oxford, Bleckwell, 1963, p.227e. 
elephents, cricket, roses ox a new theory concerning the origins of the universe. Judging, like oriticel thiniving, is specific to a particular realm of movledge or skilled aotivity and hence without generelity except insofar as an allied field calls for common knowledge and skills. It follows from this that the idea that higher education is in part concerned with the production of people who possess 'sound judgment' needs to be viewed as no more than a polite fiction of the senior common room. It is absurd to suppose that a man could be a judge or a critic simpliciter; these are not general capacities but names for approved ways of deploying particular complexes of steills and knowledge.

\section{Creativeness}

Another quality of intellectul. worls which is often claimed to be fostered by higher education is that which is referred to by such tems as 'crestiveness', 'originality' or 'Imaginativeness'. 1 though these concepts may be notoriously difficult to define many people appear to feel quite confident that they know how to use them:

Tnowledge, sicill with the pieces, powers of calculation, a good memory and a capacity for concentrating over long periods - - all these qualities blended together will malce an excellent chess-player. But, like Gilbert's recipe for the Heavy Dragoon, the list is lacling in one 
imagination .... I shall not attempt to define what I mean by imagination in this context ... because I know what I mean and the reader does too; which should suffice for all except the most cantankerous. ${ }^{1}$

Golombek goes on to say that what he has in mind

is a distinetion between chess players whose success derives almost entirely from the excellence of their technique and those who are able to go beyond this to develop strikingly new moves or strategies: '... the difference here is that the pure technician is adept at imiteting other people's ideas whereas the imaginative player produces his own'

Psychologists have recently given a good deal of attention to the kind of thinking which is described as original, creative and imaginative. ${ }^{2}$ How have they chosen to define the object of their investigations? Here are two examples from the mainstream of recent experimentalist research:

In the area of creativity one should certainly expect to find a trait of originality. It is indicated by the scores of some tests in which the keyed responses are weighted in proportion to their infrequency of occurrence in the population of examinees .... The factor is also indicated by tests in which items call for remote associations or relationships; remote either in time ox in a logical sense.... A third way

1. H. Golombek, 'The Talue of Tmagination', The Times,

1 Apri1 1967.

2. See: P.E. Vernon, 'Creativity and Intelligence', Educational Research, VI, 163-169, 1964. 
of indicating aegree of oxiginality in taking tests is the number of responses an examinee can give that are judged as being clever. 1

Originality has been defined in terms of statistical infrequency of a response within the given culture. In adition it was required that responses be relevant to the task, show intellectual strength, and. represent some break away from the obvious, the commonplace, and the banel. 2

To adopt statistical infrequency of response as part of the definition of originality may be a useful move to make if one is primarily concerned with experimental. methodology but it i11-accords with comon usage. Many ideas which may be statistically infrequent may also be trivial and unilluminating, a point which is admitted in the passages quoted above. For an idea to qualify as being original it mat be both novel and valuable. It is simply an accident that oxiginel ideas happen to be in shoxt supply: if they became abundant this would not detract from their originality. Scarcity and novelty are not at all the same thing, for we could envisage a society in which almost everyone was producing 1 deas which were both new and valuable and the fact that we could continue to describe such thoughts as 'original' shows thet the locus of originality must lie elsewhere than in statistical infrequency.

1. J.P. Guilford, 'Traits of Creativity', in H.H. Anderson (ed), Creativiby and Its Cultivation, New Iork, Harper, 1959, $p D, 147-8$.

2. B.P. Torrance, Education and the Creative Potential, Minneapolis, University of innesota Press, 1963, p.73. 
This oan al, so be seen in our willingness to describe some of the thinking and getivities of children as being creative or imaginative. There is little likelihood of their being able to produce anything which is novel in the strong sense of being previously whnown within their culture, yet we comonly speak of the writing, play, painting and thinking of some children as being imaginative or creative. How can we do this without invoking sore notion of statistical infrequency? The answer must surely lie in the

cheracteristic manner in which 'imaginative' children behave rather than in the scarcity of such children, If an educational programme is comitted to the encouragement of oreative and imaginative ways of behaving in all children then it must be possible for the programe to succeed in these respects wi thout rendering its objectives meaningless. In other words, we must reject stetistical infrequency of response as part of the meaning of 'originality' or 'imaginativeness' since otherwise it would not be possible for us to allow that everyone could possegs these qualities. We need to distinguish a strong and a weak sense of 'original'. In its strong sense 'origine?' epplies only to ideas which are both valuable and culturelly novel in that they add to the existing corpus of knowledge. In its weak sense it refers to ways of thinking and acting which are both new and valuable to the individual. It might be 
helpful to substitute 'creative' for the weak sense of 'original' so that we ere able to apply it to everyone: chllaren will then often be capable of creativeness but only very rarely of originality.

What is it to be capable of creativeness, or to do something in a creative or imaginative manner? Reople can be creative in all kinds of ways: in their personal relationships, in their gardens, in their cooking, in their chesspleying, in their writing, in their conversations, in their moral deliberations and in the manner in which they go about their professional intellectual tasks. Here we need only concern ourselves with the last of these, with ima ginative or creative theoretical activities.

Thinlcing can be conducted in a routine, derivative, stereotyped and imitative fashion. If a teacher demonstrates to a student how to solve a particular problem ox class of problems he is teaching the student a technigue which the student must learn to epply successfully. A good deal of

1. Hor at any level of energy or intelligence there can be more or less of creating in our senge. Stupid people create for each other as well as benefiting from what cones from afer. So, too, do slothful and torpid people. I have been speaking of creativity, not of genius, ' J.S. Bruner, The Conditions of Creativity' in H. E. Gruber (ed), Contermorary
Approaches to Creative Thin'ting, New Yort, A therton Press, $1963,2.17$. 
teaching congists of such demonstrations coupled with the injunction 'Do it like this'. But if the tesoher ends by asking whether the student thinks that the demonstrated technique is in eny way defective and invites him to indicate ways in which it could be improved, then he is encouraging him to be creative - - and oriticel. For to be criticel of performences is, in port, to suggest new ways in which they could be performed, to create new ways of performing. The student might be able to offer a novel modifioation, ox even to suggeat a completely new technique, and so qualify as an originator. But usually he is being invited to make suggestiong which will be creative rather than original. His teacher will rarely be surprized by what he says, al though he may often be dismayed, since he already knows the conclusions towards which the student is being encouraged to move. He is already familiar with the standard procedures, the accepted dodges and the decisive test or axgument; one of his objects is to lead the student to discover these for himself and the student who becomes increesingly sble to do this without too much prodaing and without too many clues is the one who is thinking creatively and fuging his imagination'.

A student who simply did what his tencher did would not be thinking creatively or critically -- al though 
it might put him on the rosd to such thinking - since he would not be 'thinking for himself'. He mould be parroting, mimicling, imiteting: these require thought but not the kind of thought in which there is scope for imagination. This leads to a very puzzling feature of what are called the qualities of mind', namely, the question of how they can ever be developea in other people as a result of the didactic activities of those who alreedy possess them.

Originelity clearly cannot be teught: there are no recipes for making scientific discoveries, for producing illuminating philosophical theories or for writing or composing master-worlis. These are not mle-governed activities the success of which can be guaranteed by following a formula. The same can be said with regerd to wit and humiour: witticismscannot be produced to ordex, they are inexplicable happenings which delight and astonish the wit as much as they do his audience. An after-dinner speaker might be well-advised to learn some of the contents of a book of enecdotes but no one supposes that his success in so doing will transform him into a wit, for a wit produces the kind of stories to be found in such compendia - - he does not

1. For a discussion of a related problem, that of how a learner can come to do more then he has been taught to do, see: G.inyle, Teaching and Training', in R.S. Peters (ed), The Concept of Education, London, Routledge, 1967. 
reproduce them. Deople in this category are, so it seems, witty not by cholce but by destiny'. I

If this is the case would it be possible to teach people to be witty or humolrous? Suppose I set up an acaderny with such a purpose and enrol some students for a course which consists of dining together every evening in order to provide an occasion for witty conversation. Iven if I am acknowledged to be the greatest wit in the land, how am I to teach others to do, aven to a modest degree, that which I am able to do conspicuously well? There is, of course, a technique associated with the telling of stories and jokes which it is possible to teach, but that is not what we are concerned with here. We are interested in the man who writes the scripts rather than the man who reads them.

\section{In my academy there would be nothing that I}

could do except act as an exemplar, for there is nothing which I can teach my hopeful students. I cannot even guarantes that, when we meet this evening, I sholl even be able to produce any examples of wit for them to admire. For witticisms are not produced or manufactured by me: I simply 'come out with them', and theix origins are as raysterious to ne as they are to ry appreciative audience. Being witty is therefore not a capacity in the sense that the ability to

1. 11. Grotjahn, Beyond Laughter, New York, MoGraw-Hill, 1957, p. 43. 
swim, or speak French or to recite Eskino Nell are capecities, for if I truly possess these capscities then I can demonstrate that I have them at any time I choose. But I cannot be witty at any time I choose. Neither can I fail to be witty either, for being witty is an achievement for which there is no task analogue. And if there is no task at which a wit works, sometimes successfully and sometimes not, then how can he teach anyone else to do what he is sometimes, unpredictably, able to do?

Even if the conversation at dinner goes well and I come out with some brilliant jolres, what is it that the students are expected to learn from me? Thet instructions can I give them? They must, of course, attend to what I say and try to appreciate its point, but assuming that they are able to recognize and appreciabe the peculiar force of a witty remark when they hear one, how does this help them to make such remarks themselves? Since I am unable to say. how I come to make wittioisms it is not within my power to assist them to do likewise. ${ }^{I}$ I do not went them to imitate

1. Arthur Toestler has said that the creation of humour often involves an element of originality; '.. a shift of attention to sone feature of the situation, or an aspect of the problem, which was previously ignored, or only present on the fringes of awareness. The humourist may stumble on it by chance; or, more likely, guided by some intuition which he is unable to define'. The Act of Creation, London, Hutehinson, 1964, p.93. 
me in the sense of simply repeating the things I sey: I want them to say the kind of things I say. 'I am going to cone out with a witty renark: attend to what I do and then try to to the same'. But what is it that I do? I do not do anything beyond uttexing witicisms. I cannot even announce the coming of a witticism. There is thus no equivalent to showing how or telling how -. there is simply the doing, the making or creating of a joke. Beyond attending to the joke and trying to see its point, there is nothing further for the student to do.

The same considerations apply to originality. I eannot know beforehand what oxiginal idea I dim going to come up with since it would not then be original. Nor can I resot in a flexible tinnex to a novel situation after describing to students what it is that I am going to do. Nox can I sey in edvanoe whet ortical renaxks. I an going to make about a pexformance which has not yet been given or a book wich has not been written. How, then, can I teach others to do these things

\section{But if I cennot instruct others in such a way} thet as a result they will, be witty, imaginetive, creative, Plexible and adaptable then what connection is there between these quelities of mind and the teaching in schools and universities which is aliesed to promote them? I have tried to show that we cannot teach students to be creative or 
original; all that can be done is to put them in the way of working in a manner which will merit such adjectives being applied to what they do and this brings us back to the point that I have been stressing throughout this chapter. In order to be creative the student must be able to go beyond what he is now able to do, but he must also have a base from which to extend himself in creative directions. Even to be able to recognize creativity and originality in the work of others he must know a good deal about the field in which they are working. 1 Just as criticism cannot spring from ignorance, so the appreciation of oreativeness can only come from being familiar with the routine, standard and accepted ways of doing things. 2 The ability to recognize creativeness is thus hervily field-dependent and not a quality of the mind which is in any sense general. This must also be trie of the ability to be creative for one must have some comand

1. Natson's account of the discovery of DNA strongly suggests that he was very ill-prepered to contribute to this problem, Jet on a number of occasions he recognized the vital significance of work on allied topies by others end was able to use it in his own theorizing. J.D. atson, The Double Helix, London, Weidenfeld \& Nicolson, 1968.

2. J.S. Bruner defines 'ereativity' as 'an act that produces effective surm rise', Although this definition seems to me to be unsatisfactory he makes the important point that '... surprise is the privilege only of prepered minds minds with structured expectancies and interests .... For it takes preparntion -. be it in mathenatics, soience, or art - to discern what is trivial improbability and what is effective surprise'. "The conditions of Creativity', op. oit., $\mathrm{p}, 4$. 
of the routine and the familiax in order to go beyond 1 t. $^{1}$ The aim of instruction with respect to the fostering of creativeness in students must be to equip them with the knowledge and techniques which will put them in the way of transcending what they leam by acquiring further knowledge of their own initiative and so emancipating themselves from total reliance upon what their teachers heve told them and shom them. The student is not expected to advance the subject which he is stuaying, ${ }^{2}$ to make a scientific discovery or to re-draw the map of leaming: to give evidence of creative thinicing he must take the initiative in advanoing his own understending, form his own opinions, explore 1 deas beyond those presented to him by his teachers, try to bring together what he reads and hears in a constructive and independent manner, and, in general, begin to strike out on his own with growing confidence and competence. As Ryle has

1. There may well be some counter-examples in the field of invention. Weny inventors produce new 1 deas in areas outalde their om field: a mortician invented the automatic dial telephone, a lawyer invented xerography, and the pneumatic tyre was invented by a veterinary surgeon. But even in such cases as these it could be argued that the persons concerned must have known a good deal about the problem which their invention solves; after all, one cannot simply 'invent xerography'. See: N.H.Mackworth, 'Original1ty', American Paycholoeist, XX, 51-66, 1965.

2. Moberly cites a remaxk made by Six oliver Lodge which is apposite here: '... the beginner has no right to expect any subjective discoveries.' The Crisis in the University, op. cit., quoted on p.183. 
remarked: The teacher introduces the pupil to the ropes, but it is for the pupil to try to climb them'?

\section{Independence}

The notion of intellectuel 'autonomy' or

'independence' is fundamental, to any account of skills, capacities and attitudes. Such concepts as 'critical', judicious' and 'creative' rely heavily upon the idea of the thinker proceeding independently, that is, forming his own conclusions and opinions ... thinking for himself'. "The eduoational significance of this is recognized in the Report of the Hale Committee which asserts that '.. the most important purpose of a university education ig to teach the student to think for himself....

There is a danger here of teachers in general, and of exeminers in perticular, making demands of students

1. G. Ryle, 'Teaching and Training', op. oit., p.117.

2. Por any able pupll it is a great day when he throws off the shackles of the text-book, and develops a limited trust in his own judgment and conceives a great longing for the time to come when he can trust it more. That pryil, whatever his defects, has learned the inner meaning of university education'. B. Truscot, Red Brick University, op. cit.,p.143.

3. Report of the Committee on Unitersity Zeaching Methods, the Pranks Commisgion on tutorial teaching: 'At its heart is a theory of teaching young men and women to think for themselves'. Repoxt of Comission of Inquiry, vol. 1, op. oit, para. 217 . 
which ore highly unrealistic. It is one thing to look for and encourege signs of oreativeness and independent thinking but quite another to pley dorm the importonce of imityation and repetition. Students are sometimes penelized for failing to come up with eritici sas of theories and arguments which heve taxed the powers of many outstanding thinkers, Two points need to be borne in mind in assessing the intellectual performances of students: the difficulty of producing fresh foot-prints on ground which has already been well-trodden by so many others; and the need to be thoroughy familiar with standard solutions to problems before one can be in a position to develop new ones - or even to see any defects in the old ones. To say of enswers in examinations that they simply describe the views of others or repeat stock comentaries on then is to overlook the fact that this kind of familiarity with a subject is a necessary first step towards the development of thought which is genuinely critical. It may be that 1 it is only by becoming familiar wi. th what others have said that we can learn to speak for ourselves.

It might be good advice for a joung scientist to tell him to go and work in the laboratory of someone like Rutherford in the hope that he might piok up something which will help him to produce original ideas of his own later, but prior to reaching the stage of being able to benefitt 
from this kind of learning experience it will be enough for the student to be taught by people who are well acquainted with the comonplace stratesies of intellecturl work and who are skilled in teaching these to otudents in such a manner as to open the way for ereativeness and imagination. If there is a difference between being original end being able to recognize originality then it will be sufficient if teachers possess the second cepacity. They will then at least not discourage those students who ghow signs of outstending potentialities and they can equip all students with the capacity to appreciate ideas which are strikingly novel and productive. If this is the case then there is little point in continuing to maintein that university teaching and research are mutually supportive activities.

1. All too often both secondaxy and higher education fail to achieve even this largely neutral result and seem to discourage inventiveness and independence in fevour of a safe and comfortable conformity. Hence the need to ensure that teaching goes beyond giving familierity with standard techniques and criticisms. Industrialists are no doubt often justified in their compleints concerning graduates who have been too well-drilied in whet is familiax and acceptable. A deputy chaiman of ICI has described the object of estabiishing a new type of laboratory in which the curiosity and inventiveness of raduates might be re-activated: ithe are undoing the effects of partial brain-washing, restoring the natural curiosity so evident in children, and purging from the system of our young lions the tranquilitiers administered to them over the previous fifteen years by our educational system ....' D. Davies, 'A Scarce Resource called Curiosity', The listener, 4 May 1967, p.577. 
The coneept of 'intellectual autonomy' or

'Independence' has been picked out by many theorists as being of fundamentel importance for eny account of the achievements which higher eduodion is concerned to promote. There are two reasong for supposing this to be correct. The first is that the type of mental-conduct epithets which bave been examined in this chapter are always applied with the implication that whatever the agent does when woxking at intellectual tasks is ' 21 . his own work', so to speak. To displey creativeness, critios thought or-sound judgment is necessarily to do something independently, to think something out for oneself. The second reason is in many ways much more important, and has to do with the concept of 'education' itgelf. If the skills, capacities and attitudes fostered by an educational programe axe of such a charecter that they are not subject to mastery then this entails that they are indefinitely open to modification as a result of furthex leaming. The achievenentis which a learnex may attain as a consequence of his education are only won after working at a veriety of tasks over a considerable period of time, and the successful outcome of such efforts is not only uncertain but also, in an important sense, impossible to realize on accolnt of the permanently open-ended nature of the tasiss. Ryle's account of achievement words is built around the congideration of such examples as 'finding; 'winning' and 
'solving' which have deterninate criterie for success. 'Bducated', however, will not fit into this category for the achievenents which fall under it are logically distinct from those which report the successful outcone of a search for a nissing person ox of an attempt to solve on al gebraic problem. 'Bducated' does not refer to a determinate set of tasits with decisive criteria for success. Te usually think of education as a process, or family of processes, wi thout any endpoint and this festure of the concept is recognized In such locutions as 'Lducation is a life-long business' and in our refusal to allow a use for such expressions as 'Wy education is now complete'/- a point which is frequently made in graduation day speeches by Vice-Chanceliors. ${ }^{1}$ Similarly, although wo will readily admit that someone can be under-educated ve will not allow that anjone can be overeducated, ${ }^{2}$ Education is not only a good thing but, like heal th, it is impossible to have too much of it. This is a consequence not only of the normative features of 'education'

1. Compare Cornelius Vanderbilt's remark: 'If I had learned education I would not have had time to leam anything else.' guoted in Time, 21 lley $1965,2.16$. He may have mean that there was too much (by way of infomation) for a man to learn in a lifetime: what I am suggesting is that the charactex of what is to be learnt is such that it makes no sense to speak of completely learning it.

2. 'Over-learning' is a psychological concept which has no analogue in education. 
but also of the open character of the skills and capacities to which it relates.

We must be careful, however, not to be carried away by talk about education being a life-long business since there is an important respect in which this can be highly misleading. It is one thing to admit thet our education will al ways remein incomplete but quite another to infer from this conceptual point about 'education' that we ought therefore to look forward eagerly to a golden age when everyone (excluding teachers presumably) will be 'getting an education' from the cradle to the grave. If education may be said to have an aim then it must surely be that of putting people in the way of experiences which themselves are not educational. Ieaming to play games is an educational process but playing games is not; leaming to write and speak with precision and luenoy are educational experiences, but writing a novel and addressing the Conservative Conference are not. The deliberately contrived educational experiences through which we pass cannot be extended indefint tely otherwise we would have no opportunities to engage in the activities for which they are a preparation and they nould thus lose their point. There are other things in life apart from learning.

\section{The concept of 'independence' allows us an} escape from the horror of an endless educational future since 
it can be applied in such a way as to define the achievements which distinguish an educated person from someone who still stands in need of what an educational programme has to offer. To describe a man as 'educated' is not to claim that he knows everything, can do everything and has in all (or any) respects attained his 'perfection as a man', since it will always be possible for him to improve his skills, extend his interests and knowledge, deepen his understanding and enlarge his sensibilities. To be 'educated', in the achievement sense, is to have reached the point where one can continue without further supervision and guidance. The educated man is thus truly independent: he is equipped to conduct his own affairs, govern his own life, make his own decisions and, in general, think for himself. Once a student has reached this stage then he has no further need of an educational programme arranged for him and administered by others for he is now able to devise one for himself and his former teachers have become his colleagues. He is still learning, just as they are, but he is now in a position, as a result of their efforts, to teach himself. Whereas formerly he was being towed along by his mentors, 
now he is able to proceed under his own steam. ${ }^{1}$ It is the distinguishing mark of higher education that it offers scope for evidence of independence to become manifest.

1. 'Any mind is disciplined in a subject in which independent intellectual initiative and control has been achieved. Discipline represents original native endowment turned, through gradual exercise, into effective power. So far as a mind is disciplined, control of method in a given subject has been attained so that the mind is able to manage itself independently without external tutelage. The aim of education is precisely to develop intelligence of this independent and effective type - - a disciplined mind.' J. Dewey, How We Think, New York, Heath, $\overline{1910,}$ p.63. 


\section{CHAPTER V}

\section{Developing the Person}

Many discussions of higher education tend to disregard large areas of human experience which are profoundly important: our experience of the need to make moral choices, of love, friendship, isolation, disappointment, frustration, community -- in short, the whole 'Peeling' side of life -- tends to receive scant attention. So does what is involved in self-knowledge and an understanding of what it means to be a person connected through an immense veriety of complex relationships with other persons. Yet these are all matters in which we are intensely interested and to which we attach the greatest significance. The fact that these aspects of experience are commonly overlooked would be of little consequence if we were concemed only with professional training, but when we are attempting to determine the nature of an educational programme then they cannot possibly be ignored. But the 'non-intellectual'

elementg in our experience do not lend thenselves readily to neat classification and objective treatment: they tend to be inchoate, diffuse and diffioult to verbalize qualities which the academic mind finds unattractive. 
Neither do they comprise a mode of understanding or explain ing the world which we can edopt simply by attending earnestly to accredited instructors. Yet the quality of our lives is largely determined by such experiences and if they are to be grasped at all then some attempt must be made to discuss them in a meaningful way.

The concept of a 'person' is both one of the most primitive and one of the most complex concepts that we have. 1 To say that a being is a person is at least to say that it possesses (or has the potentiality for possessing) the powex to reason, to experience an emotional life, to act independently and the right to be viewed and treated in distinctive ways by other beings. 2 Education does not confer personhood;

1. The idea of man, and of that which is distinotively human, is of much greater generality, [than the notion of 'engineer'] and, if this 1 dea was once made firm and clear in its outilnes to me, it seems that every other essentialiy aisputed notion must fall into place, including those that are peculiar to aesthetics and politios. If most clasufications of things, other than the disinterested classification of science, have their grounds meinly in human powers and interests, the distinguishing of these powers and interests, and the understanding of their relation to each other, have an absolute priority in understending the whole range of oux thought and the structure of our vocabulary ${ }^{\prime}$. S. Hampshire, hought and Action, London, Chatto \& Windus, 1959, D.232.

2. Compare Fom Paine's observations, in Rights of Man, on the hereditary principle: 'Tings succed each other, not as rationals, but as animals .... It requixes some talents to be a comon mechanic; but to be a king, requires only the animal figure of a man - a sort of breathing automaton'. E.P. Thompson, The Walcing of the Bnglish Working Class, 
it brings out or develops cheracteristics which all persons share to some degree either in actuality or in potentiality. One can be an uneducated person - all children are this - but only persons can be educated. An educated person possesses not only intellectual capacities of the kind considered in the previous chapter, but also traits of character, a moral nature, and the capacity to decide and act independently. These non-intellectual components in the concept of 'person' must now be examined sinee these features in many accounts of the nature of higher education: they were referred to by J.S. Nill in his phrase: 'capable and eultivated human beings'; and by the Robbins Report in claiming that it was the task of higher education to turn out 'not merely good producers but also good men and women'. The recent literature contains many references to the need for higher education to relate to a good deal more than whatever is involved in intellectual development. Fawthrop, for example, says: The whole purpose of education in my view should be, not only to train people to be experts in their own fields, but also to develop the spiritual, moral and political awareness of every single citizen'. 1 others speak of a need to help students in forming '... a philosophy of

1. Fawthrop, Education or Examination, op. cit., p.29. 
Iife, however provisional, a definite view of the ends to which it should be directed and of the principles by which it should be ruled, a clear idea of good and bad in conduct'? Noberly was very critical of what he saw as a failure on the part of the universities to transcend 'academic neutrality' and develop value commitments in students; university teachers, he said, must not be neutral or fear to express their personal convictions: To commicate these frankiy must not be regarded as a breach of professional etiquette, while to have none to communicate is a mark of professional incapacity' ${ }^{2}$

If higher education is to cover such purposes as these then there is clearly great scope for contertion since there is widespread disagreenent about questions of value, political belief and action, moral choice, the best social arrangements, and the worthiness of various emotions and attitudes. But many 'intellectual' questions are scarcely less disputatious and they are certainly of no greater import. The main task would seem to be that of clarifying what is meant by 'higher education' when it is construed in

1. R. Livingstone, Some Thoughts on Univergity Education, London, Cambridge University Fress, 1948, p.23. See also: M.I. Jacks, Total Education, London, Kegan Paul, Trench, Trubner, 1946.

2. Moberly, The Arisis in the University, op. cit., p.110. 
this broader sense and thus connected with our ideas about the nature of 'educated persons'. Having got clearer about this it should then be possible to see what relations hold between the affective and cognitive aspects of education and to consider ways in which the attributes to which they refer are most likely to be promoted through an educational

programme. I shall begin by looking at the intellectual virtues and then move on to consider moral education, indoctrination, and comitment to action. The first of these follows most readily from the notion of 'training the mind' and is perhaps the least troublesome; the other topics get progressively more difficult and contentious.

\section{The Intellectual Virtues}

\section{It is misleading to suggest that a sharp}

distinction can be made between cognitive and affective states and capacities since there is probably always a 'feeling' side to knowing just as oux interests, attitudes and emotions are to some extent bound up with what we know and believe. ${ }^{1}$ Yet there has been a marked tendency on the part of teachers and educational theorists to concern themselves to an excessive degree with cognition and to neglect the affective aspects of education. This has something to

1. See: I. Thalberg, 'Emotion and Thought', in S. Hampshire (ed), Philosophy of Mind, New York, Harper \& Row, 1966. 
do with the fact that cognitive processes are much more fully understood and more resdily 'neasured' than affective ones. 1 It is also connected with a growing awareness of a widespread lack of confidence in the validity of moral pronouncements and of value judgments in general which has made many educators uneasy about their traditional role as purveyors of established morality and models of rectitude. Nevertheless, our concept of 'education' remains much more wide-ranging than our notion of knowledge: it is still closely related to a view of man as a being who not only knows but who also feels, values, chooses and acts. Bven the exercize of intellectual silils need not be coldly 'academic': it also implies values and attitudes. ${ }^{2}$

If we describe a man as 'educated' we are implying not only that he possesses knowledge and intellectual skills but al so that he eares about these skills and knowledge, that he has an abiding interest in pursuing some of the activities in which they cen be exercized, and that he does in fact engage in such activities. Those affective

1. For a useful survey of empirical studies see: J.B. Edwards, 'Some Studies of the Voral Development of Children', Educational Research, VII, 200-211, 1965.

2. It is worth noting that where 'academic' has taken on a pejorative meaning this is usually in contexts where feelings and values are discounted e.g., "merely academic", "an academic question", and "of academic interest only". 
characteristics which are closely tied to the exercize of intellect it is convenient to call the 'intellectual virtues'. If a man, however knowledgeable, lacked these virtues, we would be unwilling to call him 'educated' sinee the successful deployment of intellectual powers is inextricably entwined with the possession of certain qualities of character. But there are other virtues which are independent of intellectual prowess yet which are held to be equally valuable. We want people to be kindly rather than vicious, considerate rather than selfish, tolerant rather than bigoted, agreeable rather than curmudgeonly, possessed of broad rather than narrow interests, and imbued with both morel and aesthetic sensitivity. I shall argue that it is a part of the task of education to develop such personal qualities and that we should refuse to call a man 'educated. who lacked them. ${ }^{1}$ An educational system is not, of course, the only agency engaged in this task; nor is it perhaps the most important one, nevertheless part of the achievement aspect of 'education' does refer to personal characteristics which lie outside the exercize of intellectual powers and 1t is this which is being stressed when we speak of education as being concerned with 'the whole man'. And if

1. See: Nary Glover, 'Bducating for Human Understanding', in llarjorie Reeves (éd), Eighteen Plus, Jondon, Faber, 1965. 
this is the ease then an educational programine will be partly characterized by the provisions which it makes for developing qualities which cannot be subsumed under the concept of 'training the mind'.

To what extent is it true that the cultivation of intellectual excellence necessarily involves the development of the intellectual virtues? It has sometimes been claimed that the pursuit of learning necessarily involves a comitment to the intellectual. vi rtues. Russell, for example, says that:

Although improvement of character should not be the aim of instruction, there are certuin qualities which are very desirable, and which are essential to the successful pursult of knowledge; they may be called the intellectual virtues. These should result from intellectual education; but they should result as needed in learuing, not as virtues pursued for their own sakes. Among such qualities the chief seen to me: curiosity, open-mindedness, belief that knowledge is possible thotrgh difficult, patience, industry, concentration and exactness. 1

Truscot also claimed that scholarship and certain traits of character are insaperable and he believed that examinations are often a good test of the latter:

of concentration, for example; of a sense of proportion; of initiative, imagination, and the control of imagination by prudence and reason; of perseverance, staying power and the kind of courage which battles doggedly against seeming odds.?

1. B. Russel1, Education and the Good Iife, New Iork, Liveright Publishing Corp., 1926, p.149.

2. B. Truscot, Redbrick and these Vital Days, London, Faber, $1945, \mathrm{p} .127$. 
The Report of the Farvard Committee replied to the objection that the university should concern itself solely with the eultivation of intellectual powers by asserting that:

... It is impossible to separate effective thinking from character. An essential factor in the advancement of knowledge is intellectusl integrity, the suppression of all wisheul thinking and the strictest regaxd for the claims of evidence. 1

\section{If selentigts were willing to 'cook' their}

results in order to secure early publicetion and reputation, or if scholars in the humanities wittingly used invalid arguments in the hope that these would pass un-noticed or deliberately disregarded evidence which threatened to undermine their own views, then there would indeed be a poor prospect fox the advancement of knowledge. Such actions have not been unlcnown yet they are perhaps far less common than the 'borrowing' of the ideas of others without due acknowledgement, the maintenance of unnecessary secrecy about the detalls of one's own work, the widespread practice of adding the names of senior staff members to a paper written by a graduate student, and the padding of

1. Ceneral Education in a Free Society, Cambridge, Itass., Harvard Universi ty Press, 1945, 2.72. 
one's list of publications with trivia. ${ }^{1}$ Actions such as these may not hinder the advancement of lknowledge but they are certainly inconsistent with an ideal of scholarship which excludes self-advertisement, power seeking, and plain dishonesty.

If engagenent in scholarly activities requires certain personal qualities for success so the induction of others into these activities involves the fostering of such qualities in the learner. To come to understand something of mathematics, history or philosophy involves acquiring both knowledge and technical skills and this, in tumn, requires the learner to develop certain attitudes towards what he is doing. The young historian needs not only to learn to distinguish between good and bad evidence but al so to become comatted to the search for evidence which is wellgrounded and relevant. In coraing to learn what constitutes evidence he has also to develop a desire to seek it out. regardless of difficulties and not be satisfied with conclusions which reveal a cavalier attitude to the facts. In other words, he has to be brought to care about the way in

1. There is nothing new about this phenomenon. The Dean of Columbia University fifty years ago remariked: 'The University Bibliography is printed each year and gives thirty or more closely printed pages to the individual contributions of officers. Of course some of these records are padded there is one case of a man whose mere list of titles for a single year covered nearly four pages ....' Quoted in D. Bell, the Reforming of General Education, op. cit., p.297. 
which he proceeds and to gresp that there are standards towards which he must strive if he is to make headway with a complex theoretical or practical activity. ${ }^{2}$

It is possible to distinguish between knowing what it is to do something well, and acting in accordance wi th such knowledge. Teachers clearly have such a distinction in mind when they say that a pupil knows how to write clearly or compute accurately or play a musical instrument with precision yet is too lazy to take the trouble to do so. The task aspect of education involves bringing the leamex not only to know that something is the case or that a sirilful performance must conform to certain standards, but also to act upon this knowledge. Similarly, the achievements to which 'educated' refers all have an affective component which will be exhibited in the manner in which the educated pexson behaves when he is dealing with intellectual tasks. His behaviour will be characterized by the accuracy, patience, care and industriousness with which he worics. We would not call a man educated who, al though he could tell us

1. 'A man cannot really understand what it is to thinls scientifically unless he not only knows that evidence must be found for assumptions, but also knows what counts as evidence and cares that it should be found .... All forms of thought and awareness heve their own intermal standards of appraisal. To be on the inside of them is both to understand and to care. Wi thout such comitment they lose their point.' R.S. Peters, Bthics and Education, op. cit., p.31. 
what was involved in doing history, science or literaxy criticism, did not take the trouble to meet these requirements when he engeged in these activities hirself.

An educational programe sets out not only to develop an understanding of the nature of various intellectual activities but also to foster certain attitudes towards some or all of them, and if these attitudes are not in fact developed then we will be obliged to admit that the programe has failed. In other words, part of the meaning of 'educated' is that the individual to whom it is applied possesses both knowledge and positive atti tudes towards what he knows. But these affective components of the achievement of being 'educated' relate to more than the intellectual. character traits whioh are necessarily called for in doing history, science or philosophy; they also range over more general attitudes towards these activities. Por an educational programme to be successful the learner must emerge equipped with a desire to extend his knowledge and understanding, with a continuing curiosity about and interest in what he has learnt, and with the will to contimue to pursue knowledge even when all extrinsic incentives for study have lost their force. Indeed, paxt of the point of education is to replace external incentives with an internalized autonomous desire for knowledge for its own sake. 
We would thus expect a graduate in literary studies to continue to read widely and with increasing discrimination and sensitivity. Te would expect his educstion to have developed in him an interest in literature and a feeling for books which would continue indefinitely even though he is no longer obliged to read in order to pass examinations or to satisfy the demands of his tutors or the ambitions of his parents. If his interest in literature ceased entirely as soon as he graduated then we would have to confess that his education had been a failure, even though he might well be very lnowledgeable about literature. The teaching of literature, as part of an educational programe as distinet from what might be done in a craming establishment, thus requires the passing on of positive attitudes towards literature as well as the development of skills and the transmission of knowledge.

The possession of knowledge, skills, the intellectual virtues and the desire to continue to engage in at least some of the activities which feature in an educational programe is still not sufficient to characterize an educated man. For even if someone satisfied all these requirements this would not be ineompatible wi th his being ungenerous, vicious, aggressive, and morally insensitive. To say that education is concerned with the 
'whole man' is to acknowledge that it has to do with a wider concept of 'person' than that encompassed by the notion of intellectual excellence and $i$ ts associeted character traits. This wider view of the concept of 'education' has been a source of contention since at least the time of Axistotle, ${ }^{1}$ but if it be accepted that education has to do with personal development then it must at least deal with moral values and moral action since our concept of a person gives an important place to man as a being profoundly involved in morel deliberation and choice. I shall now examine some of the implications of connecting education with morelity.

\section{Moral Education}

Then we speak of 'higher education' we are implicitly recognizing that the students who attend colleges and universities bring with them a history of moral as well as cognitive development: from an early age they have been encouraged, by use of a great variety of meens, to adopt a

1. There is no agreement as to what the young should learn, either with a view to the production of goodness or the best life, nor is it settled whether we ought to keep the intellect or the character chiefly in view. If we start from the education we see around $u s$, the inquiry is perplexing, and there is no certainty as to whether education should be a training in what is useful for life or in what tends to promote goodness or in more out-of-the-way subjects'. Aristotle, Polities, Book VIII. 
noral point of view. If we glence at what kes taken plece duxing the earlier eteges of the educational programe this may suggest something of what might be attempted by way of moral education in the university; it may also indicate limitations upon what might be done imposed by what has already heppened. A useful beginning is to oonstder what some psychologists have sald about the ways in which children acquire moral values and leam to speak the language of morals.

Aceording to Diaget, this ocours in two distinet stages. ${ }^{2}$ The first he calls the 'transcendental stage' in which ohildren conceive the rules of games, and of behaviour In teneral, as being 'given' and hence unalterable. At around

1. Wrom early in our lives we have all been taught to thintk before we act, not to follow impulse or instinct or inclination, but to thinls first. We have been told thet to neglect this will frequentiy give us cause to regret our action .... Iloreover, we exe constantly enoouraged or bullied to do what we ought rather than what we would like to do and to refrain from doing what we ought not to do even when we would like to do it. In our deliberations we are trying to woxls out what we should or ought to do, that 18 , whet 1 s supported by the best reasone. It is not surprising, then, that we are able to do thio, for we have been trained to do it even in the face of strong contrary impulses.' K. Baier, The Morel. Point of View, I thace, M.X., Corneli. University ress, $1958,0.148$.

2. J. Plaget, The Woral. Judment of the Child, Jondon, Kegan Ioul, 1.932 . 
the age of seven there occurs a gradual transition, to what he calls the 'autonomous stage' in which children come to appreciate that rules are conventions which may be changed if the consent of others can be obtained. Piaget supporte this distinction with a mass of observational and experimental evidence but he gives little attention to the nature of the transition from one stage to the next: he appears to assume that progress from one to the other is largely a function of maturation.

\section{Freud showed a similar lack of interest in the} manner in which rules are conceived and passed on to others and concerned himself almost entirely with giving

explanations of why cextain people fail to make the transition from one stage to the next. He seems to have accepted growth towards rationality as one of the exiteria of normality and gave his attention to behaviour which was abnormal in that it remained at the transcendental level. ${ }^{1}$ In implementing an educational programe teachers will thus be concerned with facilitating development to the autonomous stage by helping children to develop a language

1. There have been a number of attempts to develop Freud's theory of the autonomous ego by exploring some of the conditions which encourage or delay its formation. See, for example: I.H. Drikson, childhood and Society, New York, Norton, $1950 ;$ H. Hartmann, Igo sychology and the Problem of Adaptation, London, Imago, 1958. 
in which moral deliberation can be conducted and which can be used to justify and advooate the adoption of particular ideals and moral mles. Moral education thus consists in at least two tasks: the teaching of substantive moral rules and the teaching of an ergumentative language in which the rules can be discussed. As scheffler puts it:

If moral conduct is our goal. in moral edueation, we are, in effect, striving to achieve not alone the acquisition of noms of a given sort in prectice, but the reflective support of norms of this sort in an 'objective' ox 'impartial' manner.'

When a student enters college or university his character will already be well-formed in the sense that he will be disposed to act in a distinctive manner in situations which oall for moral decisions or which evoke an expression of his interests, attitudes or emotions. He comes equipped with prinoiples and rules in the light of which he will fom his judgments and govern his actions, and if these are chellenged he will often be able to offer some lind of justification for them. In general, his moral, politicel and religioug beliefs and attitudes will be firmly established and highly resistant to godification?

1. I. Scheffler, The Language of Education, Springfield, Ii.., Charles thomas, 1960, 2.95 .

2. See, for example: B.D. Bdal, The College Influence on

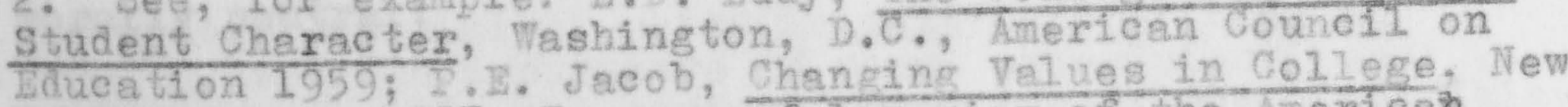
York, Harper, 1957 . Por a useful review of the Americen literature see: H. Webster, et al. 'Personality Changes in College Students', in $\mathbb{N}$. Sanford, (ed), The American College, New York, Wiley, 1962. 
If signifieant changes are to be made in these then it is clear thet the effort to be put into this will need to be of at leagt the same order as that which is given to bringing about changes in the student's cognitive repetoire. Given these assumptions about the student's affective development, what should be the university's role in morel education? The discussion which follows relies upon a distinction between moral rules and moral principles; I shall flrst try to make this distinetion elear. I take morel rules to be substantive prescriptions for conduct, e.g., The ought always to pay one's debts, be truthelu, assist those in misfortune, be honest', and so on. They answer the question: That ought I to do in this situation?" Norel principles, by contrast, do not function as signposts to the way out of moral. predicaments but rather constitute a basis for deliberation about morel issues by providing some ground for particular rules and a structure within which they may be orgenized. It is important to distinguish these from such formal principles as the universelizability thesis: Thet is right for me to do in situation $X$ must also be right for anyone else to do when in si tuation $\mathbb{I}^{\prime}$. Such principles, as flare has argued, are norally neutral: 
... offences against the thesis of universalizability are logical, not moral. If a person says 'I ought to act in a certain way, but nobody el se ought to act in that way in relevantiy similax circumstences', then, on my thesis, he is abusing the word 'ought'; he is implicitly contradicting himself .... What the thesis does forbid us to do is to make different moral judgments about actions which we admit to be exactly or relevantly similar. The thesis tells us that this is to make two logically inconsistent judgments. 1

Moral principles differ from both moral rules and logical principles such as the universalizability principle. They are unlike particular rules in that they are much more general and they are unlike logical principles in that they can be denied without self-contradiction and in that they carry substantive moral import. Noral principles are not such that we can read off from them solutions to particular morel problems; they are rather to be viewed as constituting an underlying structure which gives coherence and consistenoy to our day-to-day decisions and judgments in addition to providing an ultimate justification for them. ${ }^{2}$ Dxamples no uld be: 'Always treat equals equally', 'Always consider the interests of others', and 'Always avoid causing pain and

1. R.M. Hare, Freedom and Reason, Oxford, Clarendon Press, $1963, \mathrm{pg} \cdot 32-33$.

2. A somewhat similar point is made by Griffiths in arguing that the importance of moral principles lies '.. in making nossible the sort of reasoning of which sensible pieces of practical advice are the fruit', A.P. Griffiths, 'Justifying Moral Principles', Proceedings of the Aristotelian Society, IVIII, $10 \overline{3-124,1957-58,2.120 .}$ 
distress to others'. Prudential reasoning often makes use of a similare distinction between xules and princlples. If a driving-instructor, for example, seid to his pupil 'Hever drive carelessiy', this would be no help whatever to the learner when faced with the need to make a deciaion in a particular treffic situefion. But if he gave hin the rule, 'Never overtake on a blind bend', then the leamex would be able to meke imnediate use of this, assuming he understands the meaning of 'blind bend', in determining his actions on the road. The learner-driver would gradualiy come to appreciate that the principle 'Never drive carelessly' underlies and connects together many of the rules which he is enjoined to observe; at the same time he will come to realize that these rules cannot be deduced from the principles yet are in some sense implied by them. The prineiple 'Always drive carefully' is exemplified in hundredg of si tuations in which a driver makes a correct decision and acts in such a manner as to merit the description 'careful driver'. The notion of 'careful driving' is extremely thick: it covers an 1 mense number of responses to a wide variety of situations. By contrast, mies such as 'Park close to the 'kerb' and 'Mever overtake on a blind bend' are implicationally thin in that they offer guidance to only a very linited range of problems. The same can be said of moral principles and rules. 
Noxal rules can be taught in a wide variety of ways: by drill, entreaty, threats, example, instruction -or they can simply be 'picked up' from the social environment -- but it is now widely recognized that the manner in which rules are passed on is just as important as the content of the rules themselves. Por moral education is a matter of initiating others into traditions and into procedures for revising and agplying them; these come to be gradually taken in as habits of mind, 1

\section{In using the term 'traditions' Peters is} presumably pointing to the body of considerations which are thought to be relevant to deliberation about moral issues, to the ways in which particular rules can be supported or changed. And in leading people to grasp the nature and significance of these principles and procedures the manner in which particular rules are taught is of the utmost importance. If the object of instruetion is simply to get the pupil to learn and obey a set of rules without question then the teacher will be engaging in indoctrination rather then moral education. ${ }^{2}$ In order to determine which of these

1. R.S. Peters, Moral Education and the Psychology of Character, Philosophy, XXXVI, 37-56, 1962, 2.56.

2. See the next section for fuller discussion of indoctrination. 
activities a teacher is engeged upon it may be necessary, as Hare has claimed, to discover what the teacher is attempting to achieve. If he is simply seeking to replicate his own moral beliefs and attitudes in his pupils then he will teach rules in such a manner as to ensure that they will not be open to question in the future. Moral education, by contrast, seeks not only to fumish the pupil with a set of mules with which to guide his actions but also to equip him with procedures for revizing them if they get out of step with his deepest conviotions (his 'principles') about how he ought to behave. I shall discuss the nature of this revisionary process shortly.

The above remarks assume that principles can be taught in much the same way as rules and I see no reason for supposing that this is not the case with the exception, of course, of principles which are 'logically pure'. The universalizability principle, for example, cannot be taught in this way if only because it requires the learner to 'see' what is involved in such concepts as 'contradictory' and 'inconsistent'. There is no such requirement in learning the mules of long division or noral rules such as 'Always pay your debts'.

1. R.M. Hare, 'Adolescents into Adults', in .H. B. Hollins (ed), Aims in Bducation, Manchester, The University Press, 1964 . 
Eut even 11 we allow this, Deters is surely correct in pointing out thet principles are usually scguired through the menner in which rules are passed on rather than by direct instruotion. We do not learn principles in addition to rules but rather acgulre them With the rules. If this is the case then it suggests that an individual's entire mode of thinking sbout moxality $\pi 121$ be just as resigtant to change as the corpus of particular mies which govern his setions. By the time adolescence is rasched we have become habituated to handing morel situations in a characteristic fashion and any majox revioton of our principles will be very difficult to achieve. Such a ohange wold be rather Iike a swltoh in polltiogl or religlous allegiance in that it would involve admitting a hev matrix of Intereats and considerations to count as being moraliy 
relevant. ${ }^{1}$ this is not a common experience because of the habitual character of much of our norel life, a point brought out by Hare:

1. Russell gives a brilliant account of his own experience of one such drastic change of outlook. Duxing the period when he was working with Thitehead on Principia llathematica he visited lirs. Whitehead at a time when she was sullering extreme pain from heart disease and was unable even to speak to him. "Suddenly the ground seemed to give way beneath me, and. I found myself in quite another region. Within five minutes $T$ went through some such reflections as the following: the loneliness of the humen soul is unendurable; nothing can penetrate it, except the highest intensity of the sort of love that religlous teachers have preached; whatever does not spring from this motive is harmful, or at best useless; it follows that war istwrong, that a public school education is aborainable, that the use of force is to be deprecated, and that in human relations one should penetrate to the core of loneliness in each person and spealk to that .... At the end of those five minutes, I had become a completel. different person .... The mystic insight which I then imegined myself to possess has largely faded, and the habit of analysis has reasserted itself. But something of whet I thought I saw in that moment has remained always with me, causing my attitude during the first wer, my interest in children, my indifference to minor misfortunes, and a certain emotional tone in all my human relations', B. Russe11. Autobiography 1872-1914, interesting report does, however, need to be treated with a certain amount of caution. Russell had been thinting about many of these ideas for some time: what struck him with such forec wes not the ideas thenselves but the realization that he should act upon them by incorporating thom into his whole wey of life. Nevertheless the nature and frequency of this type of experience is sufficiently compelling to melce us sceptical when anyone claims that xadical changes in belief and outlook can only come about over a lengthy pexiod of time and as a result of a sreat number of experiences, educational or otherwise. 
A child's moral upbringing has an effect upon him which will remain largely untouched by anything that happens to him thereafter. If he has had a stable upbringing, whether on good principles or on bad ones, it will be extremely difficult for him to abandon those principles in later 1 ife -- difficult but not impossible. 1

But moral education is not concemed only with bxinging people to an appreciation of the relations between principles and rules so that they cone to act in a consistent and coherent manner: It cannot be neutral with respect to the particular rules by which they govern their actions. An educational programme does not have as its objective the dovelopment of just any kind of person since this would be inconsistent with the requirement that what is promoted by educational processes must be valuable. An educational programme can be viewed as one of the means by which children are socialized, that is, brought up to be aware of and to accept the traditions and ideals of the society in which they live; and embedded in these traditions is the complex of moral rules and principles which govern social and personal life, and the accepted ways in which such rules are generated and justified.

With young children, of course, moral rules cannot but be taught in an authoritarian manner: '... we must all start off as little Naturalists by leaming our moral values as if they are facts. ${ }^{2}$ One of the most difficult problems

1. R. M. Hare, The Language of Morals, Oxford, Clarendon Press, $1952, p .74$.

2. A. Montefiore, 'Moral Philosophy and the Teaching of Morality', Harvard Educational Review, XXXV, 435-449, 1965, p.446. 
which confronts teachers in pasing on these values is that of doing it in such a way that children will be able, at a later stage, to appreciate that rules are not facts and thus gain sotie insight into the nature of morality. And this will involve, in part, leading them to accept respongibility for their own decisions and actions and to realize that by making the cholees which they do make they are, in an important sense, determining their om oharacter. ${ }^{1}$ But to argue that moral education is concerned with developing an understanding of the 'logic' of morality might encourage the view that it has little to do wi.th what people aetually believe and do. Such an 'intelleetual' construal of moral eduoation seems to me a mistake, sinoe it follows from the conceptual connection between education and what is valuable that moral education must at every stege be attending to beliefs and actions, even though in the latex steges it may

1. This places a rather Irightening responsibility upon teachers and parents since $i t$ is they who are detemining, in part, the future character of children. To be able to say (truly) thet a student has reached the stage at which he 1 in ill respects a fully independent agent by no means relieves those who had a hand in earlier stages of all responsibility. For we cannot choose to feel in a certain way about particulax acts simply because we are now deemed to be responsible for our actions: Locke was surely right to say that we are what we are largely on account of our education. For an interesting discussion of this problem (although without reference to educetion) see: P. . Taylor, 'Moral Virtue and Responsibility for Character', Analysis, XXV, 17-23, Detober 1964. 
well be that the learner's acceptance of certain belief's can be taken for granted.

Such an intellectualistic view of morel education mey be aiscermed in a recent anelysis by Archambeult in which he concludes that:

The promotion of morel concuct is anelagous in some respects to the promotion of understanding. We cannot teach undexstending. Mor can we 'teach' moral conduct .... What we can do is to promote moral conduct by providing the means by which students cen arrive at beliefs, defend them, demonstrate a comitment to them, and develop a method for criticizing them.

While it is true thet the development of such abilities and attitudes is pert of the task of moral educatien, it is equally true that it has to do with the actual. cuntent of beliefs. For the morel educator canot rest content with fostexing an understanding of what it means to think and act morally; he must also be deeply concemed that the student becomes committed to beliefs which are acceptable. Indeed, the intellectual stage in moral education presupposes that the student already determines his actions and deliberations in accordance with rules for if this were not the ease it would not be possible even to begin the task of exanining the nature of the rules. The moral educator clearly cannot be indifferent to the pexticular rules which

1. R.D. Archambault, 'Criteria for Success in Mioral Instruction', Fervard Educationel Review, XXXIII, 472-483, 1963, p. 478 . 
are taught to children before they reach the stage at which talk of moral autonomy becomes meaningful; nel ther can be retreat into neutrality during the later stages. If a teacher is to be described as being engeaged in moral. education rather then indootrination then he must at all times be profoundly concerned with what his pupils believe and do as well as with bxinging them to an understending of the language of morals. This requixes teschers, insofar as they axe engeged in educetion, to be morelists es well. as moral. philosophers, that is, to teach particular rules and 1deals as wel. as a languege in which these can be discussed. The success of moxyt Ausetion depends not only upon the learner possessing lmowledge of rules and scting in accordance with them but also in his entextaining a belief that the rules ought to govern his ections.

If moral conduct is our goal in moral education, we are, in effect, striving to schieve not alone the acquistition of noxis of a given sort in practice, but the reflective support of norms of this sort in an 'objective' or 'impartial' manner. To teach honesty as if it wexe a kind of safety mue or a conventional. form of courtegy may effectively accomplish the first aim without in the least furthexing the gecond. 1 .

1. I. Schefflex, The Languege of Bducetion, op. oit, p.95. A similax point bas also been made by . Green: A rule of action is intended to discriminate between a right and a wrong, a correct or incorrect way of doing things. To learn to obey a rule is not simply to acguire a disposition to act in a certain way, but a disposition to set in that way because it is a correct way.' 'Teaching, Acting, and Behaving', Harvard Lducetional Review, XXXIV, 507-524, 1964, p.509. 
What Schefrler is erguing for here is the view that there is something distinctive about moxal conduct as compared with other forms of conduct which are rule-governed such that actions which are in accordance with the rules are not 10 so fecto to be described as morel. Part of what characterizes moxal conduct is the agent's ability to offer rational. support for his actions and the rules which govern them: if he aots out of unreflecting habit or prudence then, even though his behaviour conforms to the rules, it is not to be described as being moral.

\section{Yet this is surely an excessively stringent} requirement, for few people are in fact able to provide this kind of soghisticated rational support for their judgments and aotions. Is it not enough for them to feel strongly that they ought to act in the way that the rules prescribe? Thy demand that they be able to offer reasons for their actions before we are willing to adnit that their behavioux is to be described as moral? If, in reply to the question, 'why did you do that?' a man says 'Because I felt that 1 t was what I ought to do' or 'I elways do that sort of thing in that kind of situation', then this will be sufficient to indicate that the sotion was moral rather than prudentidel of habitual. If we then go on to ask him to justify his action we do so not in order to seek. further evidence for describing his action as being moral or imoral but because ne feel that 
moral judgments offer scope for argument and di scussion and are not to be classifled wi th whims and tastes. But it is not this possibility of rational argument which is the distinguishing mark of moral juagments since this applies wi th at least equal force to prudential judgments. In order to establish that an action or judgnent is to be classified as moral (or imoral) it is sufficient to be assured thet the agent acted on principle, because he felt that he ought to do $1 t$, or out of a sense of duty or obligation, or because he felt that it was the right thing to do. Moral 'oughts' appear to have a distinotive emotionel flavour to them which is both psychologically and lomicrily compelling and which provides the final justification for our actions. Hence the importance of feelings and iriagination in moxal educetion: lonowledge of rules and behaviour which confoms to rules is not enough.

It is very doubtful, whether this awareness or grasp of what is involved in the peculiar force of moral language can be taught. Understanding is something which we come by: it 'damn' on us, as we say. It comes as a result of leaxning but is not itself learnt. We can leam a great deal about a play, poem or syimphony but we cannot learn in the same way to understend or apreciate thes. Our grasp of the use of the language of morals comas to us in an analagous fashion: it develops from the manner in which moral 
rules are teught, from the ways $1 \mathrm{n}$ which moxel issues are discussed and resolved by others, and from oux own extending experienoe of moral problems as we begin to be able to differentiate these from other types of choice-situation with which we are confronted.

As far as moral edueation is concerned this is a non-problem since when children reach the stage of being able to engage in serious discussion of morel issues they already understand the foree of morel 'oughts's The problem is not to get children to undergtand what is meant by such words as 'ought' and ' duty', sinee it is difficult to see what such a programme could meen, but rather te hrins their actions into alignment with their feelings of what they ought to do. This, Iotake 1t, is what seheffler has in mind when he says thet:

Mo teach someone that one ought, to be honest thus involves not merely teaching him to be bonest;... but also trying to have him ecquire the belief thet one ought to be honest .... To tesch Y that one ought to be honest is thus not merely to try to get $Y$ to be honest; it is $2.1 s 0$ to try to get Y to be honest out of conviction. 1

In other woxds, noral education reguixes the teachex to lead the pupil to learn rules, govern his behaviour by them and believe that he pught to do what the mies enjoin.?

The most troublesome of these requirements is the third, since even though someone may have learnt the

1. Schefflex, Ibid, pp. 93-4.

2. These must be morally acceptable rules of course. 
rules in the sense of being able to recite them correctly, and also acts in accordance with them, we can always raise the question of whether he really believes in them. That is to say, we can wonder whether his actions are the result of his feeling that he ought to obey the miles or are in fact the consequence of undisclosed prudential reasoning or even of unreflecting habit. This can be seen in the following example. Suppose someone who is approaching the end of a long and fatal 1llness begins to have doubts about the motives of a relative who has been in (apparently) selfless attendance throughout. 'I wonder', he muses, 'whether my niece is really fond of me? Pexhaps she is going to all this trouble for no other reason than the hope that by doing so she will receive a substantial bequest when I die?. Despite all his vigilance in observing her behaviour, questioning her, and inquiring of others their opinions concerning her, he is unable to discover the smallest chink in her seemingly endless goodwill. If his doubts persist, in what way can he justify them? If someone is unfailingly kind and honest is there any point in wondering whether they reelly believe in being kind and honest?

When we ask of someone who never neglects to observe a moral rule, 'But does he really believe in it?' what is it that we are asking? In most cases we are evincing a suspicion that the actions in question are the consequences 
of motives other than those which we would commonly ascribe to the agent -- and motives which are morally disreputable. We suspect that rather than acting out of compassion, kindness and love, or from a sense of duty, the attentive and solicitous niece is really an opportunist who sees this as the prudent way of turning the situation to her own advantage. But in such cases we usually have some ground for our suspicions, and even when we do not they may well be confirmed by what happens afterwards: in this case by the niece living a life of conspicuous self-indulgence and frequently reviling the memory of her uncle. But suppose that we have no such grounds and that even after coming (or failing to come) into her fortune the niece continues in her saintly ways, what then? We could fall beck upon the logical possibility that, contrary to all the observed facts, the niece is concealing her real feelings and is pretending to be what she is not. But this possibility of behaviour being a pretence which conceals allegiance to principles which are prudential or immoral can only be entertained up to a certain point, since if these alleged hidden beliefs are never acted upon or avowed then it becomes highly implausible to continue to insist that they are nevertheless being entertained. ${ }^{1}$

1. For a similar argument, see: B. Bedford, 'Emotions', in D.G. Gustafson (ed), Essays in 2hilosophical Psychology, London, Macmillan, 1967, pp. 81-83. 
It is clearly not meaningless to suggest that, in a particular case, there is a possibility of our being deliberately deceived as to the real reasons behind actions, but it is very difficult to make any sense of the suggestion that such a deception should be sustained throughout the life of an individual so that we could truly say, at the end of it, that 'His entire life was a lie'. The whole point of deceiving others as to the nature of our feelings or beliefs is that we hope as a result to secure some advantage, Jet in order for this example to work such a consequence is assumed to be ruled out.

Can we then say that provided someone behaves correctly then the question of whether they really believe in what they do is not one with which we need concern ourselves? Many teachers and parents undoubtedly hold such a view since they appear to equate successful teaching with the learner determining his actions in the light of norms which meet with their approval. But the moral educator cannot share this view since he is concerned not only with securing right conduct but with ensuring that it does not spring from prudence or unreflecting habit. He seeks to teach in such a manner as will avoid the production not only of opportunists but also of 'moral automata' who, al though they may never do anything wrong, do not act out of a feeling that they ought to act as they do. And in attempting 
to achieve this end the moral educator is obliged to engage in two seemingly incompatible activities: moralizing and moral philosophizing. For, on the one hand, he must be commending particular rules, pratsing virtues and condemning vices and trying, in general, to bring his pupils to shere his own beliefs, attitudes and values; and in his other role he must practise moral indifferentism while discussing the nature of moral judgments and the ways in which they may be supported. As a moralist he must be deeply concerned about the actual content of his pupils' moral beliefs and attitudes and in ensuring, as far as he is able, that their actions conform to rules which are valuable; and as a moral philosopher he must seek to lead his pupils to a deeper understanding of what constitutes a moral issue and the various moves which are appropriate to its xesolution. There is no incompatibility between these activities provided that the teacher tries to pass on his own moral values in such a way that the rational elements in moral deliberation are constantly stressed and by taking every opportunity to encourage serious debate about moral problems so that, as a result, his pupils come to be equipped to cope with the moral life as autonomous individuals rather than being permanently (and perhaps unwittingly) dependent upon the authority and judgments of others. 
In moral education, as with intellectual training, a main aim is to lead the student to the point at which he is able to think for himself since someone who is incapable of making decisions would also be incapable of acting morally. I have been suggesting, however, that this is insufficient to characterize moral education: the teacher must also be concerned with the content of the student's moral beliefs as well as the fomel features of the way in which he conducts his life. There is a great deal of confusion about this where higher education is concerned: many people are reluctant to olaim that the universities should go beyond encouraging the student to examine the logical structure of his belief system. It is widely held that higher education should offer a challenge to the beliefs, attitudes and opinions of students: it should be disturbing rather than confirmatory. John Wilson, for example, says:

The teacher's fixst job is to have this out and to demolish the inner complacency which we all have: otherwise the student simply sits inside his castle, taking $a$ benevolent interest in what the teacher has to say, but not letting it affect him at any vital point. Proper education, like proper psychoanalysis, is alsturbing. 1

This process of administering a severe shock to the beliefs and opinions of students is generally held to provide a salutary educational experience but it is usually

1. J. Wilson, Two Types of Teaching', in R.D. Archambault (ed), Philosophical Analysis and Education, London, Routledge, $1965, \frac{\mathrm{p} .168 .}{16}$ 
thought of as being restricted to the consideration of rationales and largely (ox entirely) indifferent to the content of what the student actually believes. Corbett, for example, says:

An essential task of higher education in a liberal society at the present time must therefore be to shock students out of the uncritical acceptance of the political ideas and values of their society, and to get then to see that other societies, in our case particularly Soviet society, look at social questions in a different way. It is not primarily the business of the university teacher to say which of these sociel views, any more than which of those moral views, is right; his business is to see that students realize that these profound conceptual differences exist, and tory ts to think about them for themselves. 1

\section{Hare al so argues that as far as children are}

concerned:

What has to be passed on is not any specific moral principle, but an understanding of what morality is and a readiness to think in a moral way and act accordingly $\ldots$... It is not a particular morality, but morality itself that we are teaching... to learn this is to learn how to speak morally, understanding what one says, 2

Such accounts of the nature of moral education are scarcely surprizing in the light of the recent history

1. J.P. Corbett, 'Opening the Mind', in D. Daiches (ed), The Idea of a New University, op. cit., p.35.

2. R.ll. Hare, 'Adolescente into Acults', in M.H.B. Hollins (ed), Aims in Education, Hanchester, The University Press, $1964, \frac{\mathrm{pP} \cdot 61-2 .}{}$ 
of moral philosophy in England, ${ }^{1}$ yet they are seriously defective in at least two respects. They tend to gloss over the practical problem of the content of the rules which must be taught to young children and the virtues and ideals which are to be set before them as examples to be followed. Children are not taught to adopt just any set of rules or to admire any type of action or person which happens to attract then; they are encouraged to be brave, honest, considerate and self-secrificing; they are urged to believe thet recialism, violence and reiligious and political intolerence are wrong. Teachers and parents attempt to bring children to share their own values and convietions. Hare mentions a parent who tried to avold influencing his child's moral growth in any way, a course of action which Hare rightly calls 'obviously absurd'. And he goes on to say thet:

1. Cf. Mary Warnock's remerks upon '... the refusal of moral philosophers in Bngland to commit themselves to any moral opinions. They have for the most part fallen in happily with the positivistic distinotion between moral philosophers, who analyse the logic of moral discourse, and moralists, who practise it. It follows that they are inclined to believe that, in theory at least, absolutely any thing could count as a moral opinion, or a moral principle, provided it was framed in the way lat down for such principles, and used, as they are used, to guide conduct. It would be generally agreed that some opinions might be outrageous, and some principles harmful, but where we get our prineiples and opinions from, how we should decide between them, and what would be an example of a good one - these things they will not tell us....' Bthics Since 1900 , London, Oxford University Press, 1966 , pp. $144-5$. 
If all the time that we are influencing them, we are saying to ourselves, Perhaps in the end they will decide that the best way to live is quite different from what I'm teaching them; and they will have a perfect right to decide that, then we are not to be accused of indoctrinating. 1

We can recognize that people have a right to decide how to live their lives - indeed, pert of the object of moral education is to lead them to realize that they must make such decisions for themselves -- wi thout hoping that they will eventually decide to act in accordance with beliefs which are quite different from those which we taught them in their youth. For if we do not hope that they will come to adopt the beliefs which they are taught, then what possible justification could there have been for teaching those beliefs in the first instance? We do not teach children rules or encourage them to live up to certain ideals simply in order that these may be used later as the basis for sophisticated discussions about the nature of the language of morals: we teach rules and ideals because we believe them to be valuable and hope that children will come to share our own commitment to them.

The other weakness in the intellectualist account of moral education offered by Hare and others is that it ignores the conceptual connection between 'education' and the passing on of that which is valuable. Just as 'education' is inconsistent with the deliberate teaching of 1. Hare, 'Adolescents into Adults', op. cit., p.52. 
falsehoods so is 'moral education' inconsistent wi th the promotion of ideals, conduct and habits of mind which we do not hold to be valuable. If a teacher is engaged in moral education then he must not only seek to lead his pupils to an understanding of the nature and complexities of moral deliberation but he must also teach specific moral rules and principles and encourage an admiration for the ideals of virtuous conduct and a commitment to them on the part of the learner. ${ }^{1}$ Hare'a programme for moral education, in refusing to allow any place for the teaching of 'a particular morality', is not only impossible to implement (as Hare admits by implication) but also results in the severence of the conceptual connection between 'moral development' and 'education'.

Nany people might be willing to reject what I have been calling the 'intellectualist view' of moral education as far as children are concerned while holding that it is nevertheless the only acceptable approach to the problem of passing on values in higher education. But what is there in the nature of higher education to support such a

1. "If we believe in a particular "social character", a particular set of attitudes and values, we naturally believe that the general education which follows from these is the best that can be offered to anyone: it does not feel like "indoctrination", or even "training"; it feels like offering to this man the best that can be given'. R. Williams, The long Revolution, London, Chatto \& Vindus, 1961, p.127. 
conclusion? The main argument in favour of concentrating upon rationales is not derived from the concept of 'higher education' but from the viev of the university which sees its defining characteristic to be the pursuit of knowledge for its own sake. Since scholarly activity is objective in the sense of being value-free except for the standards which are built into the activity itself, then the induction of others into this activity does not require the fostering of any virtues other than the purely intellectual ones. Turther, the demends of shis kind of objectivity are frequently (perhes always) incompatible with comitment to particular moral, political and sociel beliefs. If scholarly inquiry is to be restricted to the description and explanation of social and physical phenomena then moral problems concerning the uses to which such knowledge may be put simply do not arise. It is considerations such as these which lead many people to reject the claim that the universities have any responsibility for encouraging students to adopt particular values and ideals of conduct.

Those who see the univergity as having a role as social critic would be much more likely to support the view that higher education necessarily involves the passing on of values; they could scarcely condone moral indifferentism in their teaching if they held that one of the tasks of the 
university was to provide an active social conscience for the body politic in which it lives.

- Mraining the mind' is only a part of what we mean by 'education': much of the rest of its meaning covers the development of non-intellectual pereonal qualities and these necessarily involve comitment to velues. It is natural enough to extend scholarly concern for criticism into the realn of values by obliging students to look afresh at their beliefs and attitudes, but this 'shaking up' process is quite inadequate as an account of the 'personal development' component in higher education. For, after all, what is the point of simply unsetting the convictions which students bring with them to the university l The point must surely be that some of these convictions ought to be abandoned and replaced not by eny other set but by ones which are more acceptable, valuable or correct. If we are reasonably clear about what we wish our children to believe and admixe, why should we hesitate to say what students should adopt by way of rules, principles and 1 deals as guides

1. This is usually simply accepted as a dogma and the difficulty of reconciling academic scepticism with comitment to action is convenientiy overlooked. 'One indication of their [students] immaturity is the demand we should tell them the Truth as distinct from more or less verifiable truths: we ought, I think, to be much more tender to such a demand. We begin by instiling habits of criticism and scepticism towards the conventional wisdom without considering what a vacuum we can create in their minds'. D. Nartin, 'Trouble in the University', The Listener, 291-293, 7 Narch 1968, p. 293 . 
to conduct? To say that we should be content with theix developing a moral point of view seems quite indefensible unless it is possible to assume that whetever is seen from this viewpoint is acceptable; but few would wish to defend such an assumption since it would entail denying that some beliefs and attitudes are quite intolerable.

\section{Wuch of the current theorizing about the nature}

of higher edueation readily leads to the invention of an abstract man who spends his time pursuing theoretical activities for their own sakes, is skilled in operating formally with the language of values, and whose intellectual and social life is characterized by a passionless objective detachment. To adopt such a model for the purposes of construeting and implementing an educational programme is to abandon reality in favour of a neat but sterile theoretical construct which scarcely touches life as we know it. If we are concerned with a wider concept of 'education' then that encompassed by the training of intellect then the values connected with 'personal development' must be introduced and handled in such a manner as to be consistent with the promotion of the academic ideals with which the universities are most closely identified. This raises two very troublesome questions. In general, how cen comitment to val ues be promoted without compromising scademic objectivity and detachment? In particular, how can moral education involve 
the imparting of moral beliefs end attitudes without degenerating into indoctrination? Questions such as these have made many people so uneasy that they have denied that it is any part of the universities' task to encourage adherence to any particular set of values. But anyone who adopts this position must abandon any olaim for the universities as educational institutions and view them simply as training centres for the development of specialized intellectual skills together with those intellectual virtues which are required for the successful pursuit of knowledge. Since I believe these fears to be largely groundless and that charges of indoctrination can be rebutted by teachers in higher edueation who do not restrict their teaching to purely factual and methodological material it is necessary to give an account of indoctrination which will enable it to be distinguished from moral education.

\section{Education and Indoctrination}

I shall attempt to answer three questions: That is meant by 'indoctrination'? Is it ever justifiable? Is it sometimes unavoidable?

\section{'Indoctrination' is usually applied in contexts} in which religious, moral or political beliefs are being taught. We speak of American children being indoctrinated with beliefs about 'American democracy' or the 'capitalist ethic', and children in Roman Catholic schools being 
indoctrinated with the Paith. These examples serve to bring out what is often thought to be an essential element in the concept, namely, that it refers to the teaching of doctrines. But there seems to be no reason for not extending it to cover the teaching of any belief whatever rather then restricting its application to doctrines or well-articulated sets of beliefs. The following passage offers a good examle of the concept being extended in this way:

\begin{abstract}
Every educational institution makes use of indoctrination. Children are indoctrinated with the multiplication table; they are indoctrinated with love of country; iey are indoctrinated with the principles of chemistry and physics and mathematies and biology, and nobody finds fault with indoctrination in these fields. Yet these are of small concern in the great business of life by contrast with ideas concerning God and man's relation to God.... The Catholic educator makes no apology for indoctrinating his students in these essential matters. 1
\end{abstract}

Some of the recent discussions of indoctrination have taken it to refer to the content of what is taught, especially any attempt to develop a non-evidential style of

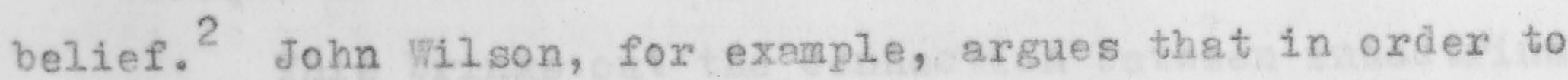
avoid indoctrination the the beliefs which are being tanght '... must be brcked by evidence: and by "evidence", of course, we must mean publicly-accepted evidence, not simply

1. M.I. McGucken, The Catholic Way in Education, Milwaukee, Bruce Publishing Co., 1937, p.60.

2. M.F. Green, 'A Mopology of the Teaching Concept', Studies in Philo sophy and Education, III, 284-319, 1965. 
what sectariens like to consider evidence $\ldots,^{1}$ on this view, disputes as to whether a particular teaching episode is an example of indoctrination turn upon whether or not there are good reasons for supposing what is being taught is true.

The claim that indoctrination is to be distinguished from education on the basis of the content of what is taught has been rejected by Hare on the grounds that since there is no such thing as a right or correct doctrine then the truth or falsehood of what is taught cannot be a criterion of indoctrination. Hare therefore rejects any analysis in teras of content and proposes instead that we examine the aims of teachers in order to determine whether or not they are indoctrinators:

The educator is waiting and hoping all the time for those whom he is eduoeting to start thinling; and none of the thoughts that mey occux to them are labelled 'dangerous' a priori. The indoctrinator, on the other hand, is watching lor signs of trouble, and ready to intervene to suppress it when it appears, however oblique and smooth his methods may be.

This brings out the connection between indoctrination and the implanting of unshakable beliefs: the promotion of ideologies necessarily involves the proscription of alternatives and the banning of deviations from what is taken to be the True Tord. The educator, as opposed to the

1. J. Milson, 'Dducation and Indoctrination', in Hollins, Aims in Education, op. cito, p.28.

2. R.M. Hare, 'Adolescents into Adults', op. cit., p.69. 
indoctrinator, proceeds by examining the grounds for all beliefs in the light of stantarda fox evaluating evidence, and particular beliefs are dismissed not because they conflict with some received doctrine but because there are no good grounds for accepting them to bextme. Hare notes that this will have consequences for methods of terching in that the indoctrinator will present his material in such a way as to discourage any questioning of its truth, whereas the educator will conceive it to be a major part of his task to lead his pupils to be critical and so come to understand what is involved in evaluating claims to knowledge. The educator follows the argument wherever it leads, the indoctrinator steers it to a pre-determined conolusion. It will not do to suggest, as does MoGucken, that because science is sometimes taught as though it were a body of received truths then this places it on a par with the teaching of religious and politieal doctrines, for although it may be that science is often taught inedequately in that pupils are given litt? or no understanding of the ways in which scientific knowledge is established, this does not make teachers into indoctrinators. They may be incompetent, but they are not 
deliberately suppressing evidence and criticism.

Wlew contributes a distinction between what he calls primary and secondary senses of 'indoctrination'. In the primary sense indoctrination '... is a matter of trying to implant fim convictions of the truth of doctrines which are in fact either false or at least not known to be true. 12 In the secondaxy sense

... indoctrination would be a matter of trying, in any sphere whatever, to 1 molant beliefs, even those which are true and known to be true, by certain disfavoured methods. And the general objection to indoctrination in this sense would presumably be that such methods are in some way incompatible with the production of a proper understanding of what is taught and of a critical appreciation of its 10 gical and epistemological status. 3

This suggests an invariably pejorative usage for

'indoctrination' and would lead us to give a negative reply to the question of whether it is ever justifiable. Yet when we get down to cases it becomes difficult to maintain that

1. There are plenty of examples in the history of science of theories being proscribed. Then Sir William Barrett, at a meeting of the Britiah Association for the Advancenent of Science, presented to Helmholtz some new experimental findings regarding telepathy, Helmholitz told him that the phenomena could not have occurred. Then Sir william said, liut I saw some of these phenomena myself', Helmholtz replied: 'Neither the testimony of all the menbers of the British Association for the Advancement of science, nor my own testimony from what ray own eyes recoxded, would convince me of teleprthy, since it is manifestly impossible.' N. Parberow, (ed), Taboo Nopics, New Yort, Atherton Iress, 1963, p.56.

2. A.G.N. Flew, 'That is Indoctrination?' Studies in Shilosophy and Education, IV, 281-306, 1966, p.305.

3. Tbid., p.305. 
indoctrination, in Flew's secondary sense, is on no account to be practised. Both Wilson and Hare recognize that this would imply the condemnation of much of what is taught to young children and this persuades them to develop differing ways of avoiding this consequence. Te have to adnit that most of what is taught to young children is at best not wholly true and that it is often taught by the use of methods which are non-rational in the sense that it is impossible to appeal to the pupils' still undeveloped powers of understanding and critical reasoning. Indeed, it might be said that the whole point of educative teaching is to develop understanding to the stage where notions such as evidence, reasons and proof can begin to get a grip, and until this stage is reached we cannot but make use of methods which are essentially authoritarian and indistinguishable from those of the indoctrinator. Teachers of the very young can be rescued from wholesale condemnation, however, with the aid of Hare's story about their aims and purposes: they have to employ methods which would be objectionable were they to be used with adults, but with chilaren no al ternative method is available so there can be nothing reprehensible in teaching in the way that they do. But if this is the case then they cannot be charged with indootrination for they are not trying to implant unshakable beliefs nor are they teaching in such a manner as to inhibit the development of those 
critical attitudes which the indoctrinator is anxious to preclude. In this way we can escape being driven to the conclusion that indoctrination is sometimes unavoidable because of psychological considerations relating to the limited intellectual capacities of young children: these may place Iinitations upon the ways in which edueation has its beginnings but they do not oblige us to continue indefinitely along the same path. The important point to be noted here is that the concept of 'Indoctrination' can only be meaningful if we can make distinctions between actul teaching processes: if education is concerned with the growth of rationality and it is the ease that there is almost no scope for engeging in rational. argument with very young children then it becomes meaningless to speek of indoctrineting them. One can only attempt indoctrination when there is a choice between rational discussion and the passing on of beliefs simpliciter: with infants, presumably, this choice is not available. Finally, it might be claimed that '.. to the degree to which our teaohings are known to be twe, to that degree indootrination is manifestly justified. "l This will not do at all, for it suggests that if we wish to persuade people to accept as true whatever we justifiably know to be

1. M.S. Breed, Gducation and the Hew Realism, Mew York,

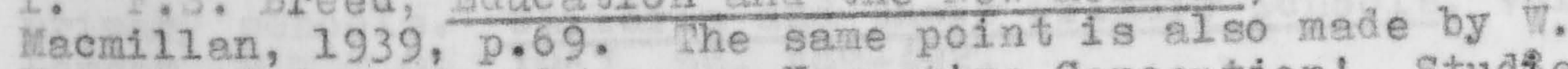
Moore, 'Indoctrination as a Normative Conception', Studies in Philosophy and Education, IV, 396-403, 1966. 
true then any method of teaching is pexmissible. But education is not primarily concerned with the passing on of truths but rather with the procedures by which truths are discovered and the standards which govern the appraisal of evidence. History, for example, connot be teught by just any methods. Unless the teacher demonstrates respect for canons of evidence and sound axgument and tries to pass this on to his pupils they will nover come to understand what history is about, for it is not the facts which are of central importance in history but the ways in which they are esteblished and called in doubt. Mhis clearly pleces quite severe linitations upon the manner in which it can be taught. For a learnex to understand whet is involved in making headway with an acadenic discipline ox accepting a belief-sy stem he has to be led to see both the need for reasons and that there are good and bad ones -- to appreciate and become comitted to the standards by which reasons are evalusted. I The indoctrinator, on the other hand, is only interested in ensuring that his pupils accept the beliefs and not that they are able to give an sccount of why they accept them. He will therefore be careful not to raise

1. Compare the reasons offered by some members of the Diowden Cormittee for excluding religious tenching from primery schools. Children and their Primery sehools, vol. I, London, H.I.. $9.0 ., 1967, \mathrm{pp} \cdot 489-492$. 
doubts and his presentation will be developed in such a way as to guarantee, as far as this is possible, that his pupils never even begin to suspect that what they are being taught could be questioned. He has to make sure that they not only accept what he tells them as being true but that they accept it as being true beyond all possible doubt. Whis is a tell oxder and we would not expect indoctrination to meet with much success outside of a totelitarian environment within which far-reaching control is exercized over what people see, hear and read.

It seems helpful, then, to employ Flew's distinction between a strong sense of 'Indoctrination' which refers to the fostering of unshakable beliefs in doctrines which are either false or not known to be true, and a weak sense in which it refers generally to a pexticulex style of belief. The indoctrinator is concerned only with the implenting of a belief whereas the educator seeks to develop a belief-style which pays due regard to the evidence upon which beliefs rest. In order to determine whether or not indoctrination is taking place we would therefore look for signs of the teacher encouraging criticism, argument, appeols to evidence and an attitude of mind which displeys a readiness to examine the bases of all beliefs. If the pupil uses his rational tool-kit as a means of inquiry, as an instrument for getting at the truth, then this would count against his 
having been indoctrinated. But if he uses it only as a bag of tricks to defend and edvocate beliefs held on non-rational grounds then this would suggest that he bad been the subject of indoctrination. But the most serious problems of moral education still remain since no space has been created for the teaching of any thing beyond methodologies.

I have been arguing that 'indoctrination' and 'education' are mutually exclusive concepts and that to teach in accordance with the former is never justifiable: might this not have some consequences which we would hesitate to accept? It is often said that one of the qualities required of a good teacher is that he should display a strong sense of his own convictions and enthusiasms and teach in such a way that these are conveyed to his pupils. Is this compatible with the avoidance of indootrination? Interests and enthusiasms are not usually associated with beliefs and ideologies and do not present the pupil with something to which he can give or with-hold his assent and thus cannot be seid to be subject to indoctrination. If a teacher tries to generate enthusiasm for literature, music or science he can scarcely be accused of implenting unshakable beliefs in doctrines which are false or not known to be true. One can be enthusiastic about the search for truth but not about the truth of perticuler propositions. Yetit might still be insisted that there remains a very weak connection with 
indoctrination insofar as indoctrination proceeds by passing on something to the pupil while at the same time concealing other things from him. Perhaps the engendering of interests can be seen in this way?. We sometimes say, for example, that we have never been able to muster any enthusiagm for nathenatios beoause an admired tescher frequently denigrated 1t. We often 'pick up' an interest because the enthusiasm of others is infectious (ideologies can elso be tranmitted in the same way) and to the extent that we acquire interests in this fashion it could be said that many of them have been quite deliberately determined by other people.

It is no doubt true that many of our enthusiasms are acquired in this fashion but to establish this is not enough to support a charge of indoctrination unless it can al so be shown that the generation of enthustasms entails the implanting of beliefs. To become keenly interested in the study of mathematics involves believing that this is a worthwhile activity. One could allow that certain activities were worthwhile without thereby being committed to engaging in them at all. But to be keenly interested in an activity must entail a belief in its worthwhileness. It must therefore be the case that if a teacher generates in his pupils an interest in his subject he is ipso facto implanting a belief in its worthwhileness. Similarly, a teacher could see as one of his tasks that of undermining the beliefs of his 
pupils in the worthwhileness of activities which he regerds as being of litule or no value. Would not such a teacher therefore be engaged in indoctrineting? The only point at which the imputation of indoctrination might get a grip here would be by showing that in enoouraging particular interests in children the teacher was thereby deliberately denying to then the opportunity to develop quite different interests. I am inclined to accept that this is in fact what often happens although it koes not follow from this thet teachers can be accused of deliberately trying to bring it abouts it is better viewed as an unavoidable consequenes of the timeconsuming character of worthwhile activities pursued with enthusiaan rather than the desire of teachers to restrict the interests of their pupils.

But suppose thet I regret my leck of interest in nathematios and attribute it to the fact that my teachers took up all ray time with the study of other subjects. This would be a rather odd position to take, especially if it went with saying that I wished my curcent enthusiasms were other than what they are. Its odaness lies partly in our feeling that our particular interests are within our power to deternine in a way that the colour of our eyes is not. I might regret not having green eyes or red hair but I could scarcely regret being wild dly keen about ericket. Yet there is also a sense in which we are not in command of our 
enthusiasms for we oannot change them in the way that we might dye oux hair. It would be odd to decide to replace one of my present interests with another since even if it made sense to make such a decision it would not follow from having made $i t$ that I would begin to feel attracted to the new activity. There are a very large number of worthwhile activities and teachers must necessarily select from among them those in which they will seek to interest their pupils: Iife is too short for them to do any thing but offer a selection. But provided that they do not discourage their pupils from extending their interestis leter the making of such a selection can scarcely be called indoctrination since, as I have argued earlier, there is no logical space for such an accusation unless it makes sense to suppose that the teacher could have acted otherwise.

\section{Bducation and Values}

What arguments can be produced to justify the teaching of substantive moral values over and above those embedded in the intellectual virtues and the pursuit of worthwhile theoretical activities? Can we assume that moral education requires the passing on of substantive principles, xules and ideals as well as the teaching of the language of morals? This is undoubtedly commonly accepted by parents

1. Itymology is suggestive here: 'possessed by a god'. 
and teachers: they see their task as being, in part, concerned with fostering in chilaren comitment to particulax beliefs. If this is rejected as beins without justification then they would be obliged to abandon responsibility for what children actually believe and rest content with trying to ensure that they can at least distinguish a moral issue from a prudential one or from a purely factual one. This seens to be Mare's position: if, es he eleims, moral. eduation pannot justifiably go beyond the teaching of what is involved in speaking rorally then there is no place for the passing on of particular moxel rules. But scarcely anyone, including Hare presumably, acts in accordance with such a view: no parent can be indifferent to the beliefs and attitudes acquired by his child and neither an teachers be indifferent in this respect to the children in theix chaxge. A11. parents seek to develop in their children a comitment to certain ideals and mues of conduct. Nobody seriously supposes that it does not matter what children believe as far as their moral actions are concerned, and most people would agree that it is one of the functions of education to pass on a set of values to children.

But when it is pointed out that there are dissgreements about questions of value this is sometimes taken to be an insupereble objection to any programme of moral education which incorporates substantive rules of 
conduct. Hare, for exomple, denies thet '... there is a right content -. a right doctrine - end, furthermore, that the teacher is the man who lmows whet it is:' l If this point is taken seriously and it transpires that people often do disagree on morel questions then morel education eannot get off the ground 19 it is to promote adherence to beliefs and rules. Because some people disagree with my views, so the axgument goes, then it is improper for me to try to pass on my values to my children. We might as well say that because some people belfeve thet seience offers the beat means for predicting the future end others put their trust in astrology then we must give up teaching science in sohools. But the factis that despite disagreenent over moral issues we do teach a morality with a content and there is no reason for not doing so to be found in the type of argument advanced by Hare. The fact that some parents teach their children to be selfish, inconsiderate, dishonest liars would not persuade me to abandon the attempt to teach my own edildren to be honest, truthful, considerate and selfless. It is difficult to see why the fact of moral disggreement should count in any way against the teaching of a particular morality. If we are engaged in an educational enterprize then we are by definition committed to the passing on of 1. R.M. Hare, 'Adolescents Into Adults', op. cit., p.49. 
values and numbered anong the most importent of our values are those associated wi th moral conduct and the nature of the good life.

But even if this be allowed it might be argued that the teaching of virtuous conduct and the setting forth of various ideals cannot be done without incurring a charge of indoctrination. If moral beliefs are passed on in such a manner that there is no appeal to reason and publicly accepted canons of evidence, then it might be seid, this must surely be condemned as indoctrination. But it is incumbent upon anyone who brings such a charge to make clear the evidential bases upon which moral beliefs and principles rest in order to establish that in a particular case a parent ox teacher is neglecting (deliberately) to matre them evident to children. No one has yet succeeded in doing this; indeed, any such attempt would be misconceived. If I am asked why I believe that it is morally right to be considerate towards others I would be unable to offer any reasons or evidence for such a belief. Thy do you believe that it is right to help other people when they are in distress?' This is a very odd question and I would not only be unable to answer it (beyond simply saying'lell, I just

1. 'Now wisdom and goodness are the aim of higher education. How can it be otherwise? Wisdom and goodness are the end of human life'. R.M. Futchins, Education for Mreedom, Baton Rouge, Louisiana State University Press, 1947, pp. 24-25. 
believe that it is right') or even to grasp what the questioner mas asking for. It is not that my fundamental moral convictions are held on the basis of flimsy or inadequate evidence but rather that they do not rest upon evidence at ell. Hence the notorious ineffectiveness of much moral. and political argument: our deepest conviotions are not vulnereble to rational objections because they do not rest upon rational. foundations. We do not hold the brutal treatment of others to be imoral because its immorality has been demonstrated to us in argunents or because the evidence for its imorality is overwhelming: we simply feel that such treatment is intolerable and morally unacoptable. This is part of what is meant by saying that this is a moral as opposeâ to a prudential or factual judgment.

\section{If this is so then moral education, at its}

deepest level of concern, offers no scope for rational argument and the eveluation of evidence, and it follows from this that it cannot be the subject of indoctrination since thexe is no choice between presenting substantive principles in a rabionel manner or in a non-rational non-evidential manner. In this respect at least, adults are permanent infants. This is not to say that there is no scope for rational axgument in morals; on the contrary, there is imnense scope since these are questions about which there is often profound disagreement and much individual uncertainty. 
We ean be shown that some of our beliefs are inconsistent, that some of our actions are out of step with our principles, that the consequences of certain decisions are other then those we had anticipated, that the facts of a case are not what we hed taken them to be: there are a great mony ways in which argument and rationel procedures can be brought effectively to bear upon our morel dilemas and the detailed fabric of our moral life. It is therefore of the greatest importance that children be taught to engage in such debates and to sit down and reason together rathex than resort to blows or give way to every passing whim and impulse. But this is not enough: I have tried to show that to equip children with a moral methodology without attempting to furnish them with worthwhile principles of conduct is to abdicate all reaponstbitity for morel education in favour of an academic ideal of critical detachment which foils to speak to our everyday morel expexience.

The most perplexing problems of moral education are not those of the justification of particular principles and idesls but the manner in which these are to be presented. I do not want my ohildren to come to share ny value system simply because it is mine but because it is the right one: I want then to share my feelings about certain actions rather then act in conformity with rules out of fear of the consequences of falling to do so, or out of unreflecting habit, 
or because they believe it to be prudent to be rule-observant. 'I want you to believe this to be right because you are convinced that it is and not because I say it it'. So we present our 1deals and principles in a great variety of ways: by example, through discussion, sometines by direct instruction, through the inaginative experience of art and literature, through evaluative discussion of historical examples, through social and political debate, and so on. The object of this elaborate and lengthy undertalsing is to develop a comaitment to thuae yalues which we deem most wo $x$ th passing on to the next generation. It may be that some or many of them will later be rejected but this should not give us cause for rejoicing, for otherwise what point was there in teaching them in the first instance? The possibility of their rejection must always remain open since we want peoples' actions to be genuine in the sense of springing from theix convictions and feelings: even if we were able to do so we would not choose to make our children into autorata simply to ensure that they never abandon the beliefs which we have taught them. The problen is to present beliefs in a manner which does not compromise the learner's growth towards autonomy or make use of objectionable coercive or manipulative methods. This is a practical problem of immense complexity, yet it is often satisfactorily resolved by teachers even though they are not usually able 
to give an adequate account of what they do and their reasons for 1 t.

$$
\text { As far ae bigher education is concemed it is }
$$

difficult to see why many teachers are so reluotant to give expression to their beliefs and feelings on moral and social issues since s budents are much more capeble than are young children of adopting an independent approach to what their teachers say. In any case, as was pointed out earlier, most questions of principle will not be in disprate. The main tasls of higher education whth regard to moral education will be that of refining sensibilities which are already wellformed by exanining issues of greater subtlety, extending acquelitence with relevant matters of fact, developing the sympathetic imagination upoa which moral insight is so dependent, improving the xigour of argment about the application of principles to particular cases, and in encouraging action in the light of understanding and comitment to principles. In schools the substantive content of moral education is rarely the subject of dispute, but at the university there is an opportunity to focus upon those areas of moral experience which cannot be readily resolved either by the individual or by society. Moral deliberation and action et this level requires all the intellectual and emotional power that we can sumon up if we are to act as fully autonomous and responsible persons who more often than not (we hope) make the right decisions. 


\section{CHAPTER VI \\ Curriculum and Methods}

Having examined the general charactor of higher education and some of its objectives it is now necessary to bxing out some of the implications of earlier analyses for the curriculum and to look at some basic issues relating to teaching and leaming. Whis whole area is dauntingly large, complex and almost entirely unexplored: the recent upsurge of interest in curriculum development in the schools has yet to have any impact upon higher education al though it has clearly revealed the primitive condition of our understanding of the tasks which face anyone who undertakes curriculum planning, development, evaluation and justification. I If our lnowledge of this area is limited as far as the sehools are concerned it is virturly non-existent with respect to higher education. I shall therefore treat a very limited number of issues, selecting those which appear most relevent

1. In his review of those currioulum problems to which philosophy might be able to make a contribution, Hirst describes his paper as being '... necessarily a kind of survey and one of work in many cases barely begun.' 2 . H. Hirst, 'The Contribution of Philosophy to the Study of the Curriculum', in J.P. Kerr (ed), Changing the Curriculum, Iondon, University of Jondon Press, 1968. The other contributions to this anthology give a good indication, in themselves, of how muah remains to be done. 
to the views of higher education which were considered earlier.

In chapter III it was suggested that there are a number of advantages in adopting a unitary concept of 'education' so that higher education can be seen as beling, in some important respeots, a continuation and culmination of what has been atternted in the schools. This inplies that the curriculum will possess a certain 'breadth' and that it will exemplify a concern for students as persons by fostering the developnent of intelleotual, qualities, values, beliefs, attitudes and a commitment to action. One obvious problem, then, is that of determining the content of a currioulum which aims at securing such objectives. This is perhaps best approsched by examining the justifications which can be advenoed for the theoretical activities in which students are typically engaged during thein higher education. The first section, therefore, will deal with the justification of curriculum activities offered by Peters and then develop the view oulined briefly in chaptex III which suggested that Iife in a democratic socieby requires a non-specialist type of edueation.

The second section will deel directly with another (but closely related) majox 1ssue which has been widely discussed recently, nathely, the extent to which the universities should be providing a training in specialigt skills and 
lnowledge, That they should provide such a treining might seem to follow from some of the conceptions of the university whioh have been examined in enrlier chapters, especialiy those which see 1 ts functions in terms of scholership, applied research and professional training.

An educationel progreme is publicly displayed in curricula and syllabuses, but it is implenented through otivities directed to those achievements at which the programe aims and which constitute (in some sense) its justification. These activitisg can largely be subsumed under the concepts of 'teaching' and 'Leaming', both of which are vague and of uncertain application in the realm of higher education. The third and fourth seotions will therefore contain an elucidation of these concepts and work out some of their relationships with the concept of 'higher education'.

There are a great number of topics which could be discussed under the general rubric of 'curxiculum and methods' but these four seem to me to be among the most important, to be tightly connected with issues raised in earliex chapters, and to be those which I feel most able to treat with some prospect of making headway. Anyone who is awere of the impoverished state of our knowledge of curriculum and teaching problems in higher education would probably agree that progress is most likely to resilf from 
an attempt to advance on a nerrow front: the construction of highly general theories would be hopelessly premature and of little velue at the present time.

\section{Breadth of Understanding}

That the achievement aspect of 'education' is strongly related to a wide spectrum of attainments is suggested by our refusal to call a man 'educated' whose knowledge and competencies are restricted to a perticular set of skilis or to a single area of knowledge. Iven if we are concerned only with intellectual attainments there is a useful if comonplace distinction between a 'broad education' and a 'narrow training' which draws attention to the range of lenowiedge and understanding which might be achieved by individuals. But to say that education has to do with the development of broad interests and a wide-ranging familiarity wi.th contemporary knomledge is to make a purely conceptual point about the meaning of 'education' and 'educated'. What arguments can be offered for constructing a curriculum which promotes such interestis? If I am deeply (or even slightly) interested in geology why should I not study this to the exclusion of all else rather than be obliged to spend much of my time in learning material in which I have no interest whatever? Te ere unlikely to find any guidance on this issue in the various conceptions of the university which have been considered earlier; indeed, many of them would 
seem to imply that higher education is necessartily specialized in nature. Preparation for scholarship, applied research end a professional life could all be taken to demand a training which is quite severely restrioted in scope. We must look, then, at the concept of 'higher education' 1 tself for guidance in determining the scope and content of the curciculum.

\section{If 'education' is construed in terms of the} intiation of young people into intringically valuable theoreticel activities then thore is a problem in deciding which activities are to be taught. Deters approaches this problem by way of a sertes of arguments which lead up to a trenscendentel deduction of what is pre-supposed by enyone who seriously poses the question: Why do this rather than thatp' If someone is wondering how best to spend his time end searches for ressons for engaging in one ectivity rather than another then he is clearly allowing that there are features of activities which make for worthwhileness and that these hold a strong attrection for him. Among such features would probably be the capacity of an activity to hold his ettention for a considerable span of time, the chellenging opportunities which it offers for the exercize of still and resourcefulness, and the exacting nature of the

1. R.S. Peters, Bthics and Bducation, London, Routledge, 1966, ch. V. 
standards of performanee which are appropriate to it.

Anyone, therefore, who is thinking seriously about how to spend his time cannot but go for activities which afford rich opportunt ties for employing his wits, resources and sensibilities in suations in which there $1 \mathrm{~s}$ a premium on unvedictability and opportunities for skili ... and a sense of the fitting. But an immense number of activities could well satisfy these requirements and would thus be open to anyone who was wondering how best to spend his time, so there rust be further considerations which justify the special place accorded to theoreticel curriculum activities in educational institutions. Several of these are discussed by Peters and he concludes that the most important of them concerns the extent to which an activity is bound up with the puxsuit of truth and understanding. Science, history, philosophy and other theoretical pursuits which are the concern of soholers have arisen from men's desire to discover the truth about the world and to understand more fully their own plece in it. It is this connection with truth, and the importance which is attached to it, which marks off curriculum activities from a host of others which, although they may be worthwhile, lack the capacity to illuminate human experience and extend lnowledge. Anyone who asks 'Why do this rather than that?' is therefore bound to be led into an exploration of this special class of theoretical activities sinee it is only through them that he will be able to find an answer to his

1. Ibid., p.156. 
question. Turthermore, the very posing of the question presupposes a measure of commitiment to the centrel. feature of all such activities, namely, the pursuit of truth. It is here that the transcendentel deduction really gets a grip, for if someone questions the pre-eminent worthwhilness of scholarship he must already possess to some degree the deep concern for truth which cheracterizes all scholarly activity. So by seriously questioning the velue of scholarship he reveals a comitment to what is supposedly in doubt since $1 .$. he must already have a serious concern for truth built into his consciousness. I the justification of the pursuit of knowledge is thus pre-supposed by any serious attempt to question it.

There are several points to be made about the adequacy and force of this form of justification. The first one that I shell consider concerns a rather puzzling implication of the argument. In his discussion of the case of a man who tries a variety of activities and then decides that theoretical pursuits are not for him, Peters suggests that this would not persuade us that such activities are not worthwhile but rather that the man had not come to appreciate what is involved in them. Once a man has gained some knowledge of the procedures and way of thought which cheracterizes say, scicace, and has as a result some insight

1. Ibid., p.164. 
into its point then he raust $1 .$. be in some way committed to its pursuit. I This olaim is of considerable importance for Peters' argument since the transcendental deduction paxtly turns upon it, as can be seen in the following passage:

To ask the question 'Thy do this rather then that?' seriously is therefore, however enbryonically, to be comitted to those inquiries which are defined by their sexious concerm with those aspects of reality which give context to the question which he is asking. ${ }^{2}$ It seems to follow from this that if people are successful. Iy initiated into theoreticel pursuits then they must, 11 only in 'some wey', engage in them. How are we to construe 'some wey' here? Peters suggests two interpretations. The first is: '... that to understand characterizations such as elegant, ingenious, shrewd, appropriate, nest and cogent from the inside is, in a sense, to be positively inclined townds doing things in some ways rather then others, 3 This is to link the understanding of an activity with engagenent in it in a perticular manner determined lergely by the observance of standards governing eppraisels of 'good' or 'correct' performances. As Peters corrsetzy points out, we would not be willing to call a man a golfer who is satisfied with merely topping a bell up to a hole snymore than we would be prepared to allow that a man

1. Ibid., p.147.

2. Ibid., p.164.

3. Ibid., p.155. 
had understood what philosophy is about if he showed no concern for clarity of thought and cogency of argument. But this is only to say that if we decide to engage in an activity with its own distinetive standards of perfomance then we must make an effort to make what we do conform to such standards; it is not to say that once the standards and point of an activity have been grasped and acknowledged then we are in some sense compelled to engage in it. I discussed this issue in chapter IV in arguing against viewing such qualities as 'critical thinking' in terms of habits of mind with its suggestion of regular and unvaried engagement and performance. Similarly, we could say here that someone may well succeed in seeing the point of golf and attain a fair degree of skill in playing it without being in any way committed to playing it regularly ('habitually') or of playing it at all once he has learnt what it involves.

The second interpretation amounts to saying that if someone seriously asks 'Why do this rather than that?' then he is committed to exploring all of the members of the class of intrinsically valuable theoretical activities. Peters admits that this presents such a questioner with a rather daunting prospect: 'If his question is concerned, as has been shown, with the nature and quality of the possible activities which he can pursue, he has really embarked upon 
a difficult and almost endless quest. 1 It is here that the extent to which someone might be said to be committed to the pursuit of worthwhile activities once he has grasped their point becomes a matter of the greatest importance. If understanding entails engagement in an activity then Peters has confronted the questioner not with a difficult task but with an impossible one. Let us suppose that he begins with the study of science: once he has grasped the nature of its worthwhileness he is ipso facto committed to its pursuit. He then finds time to embark upon the study of history and succeeds in appreciating what makes that a worthwhile way of spending his time. He then turns to philosophy and eventually gains some understanding of that. Then he takes time off from these pursuits and turns to .... Clearly, he will soon reach a point at which he will either have to abandon serious engagement in some of these activities or give up the search for the answer to his question.

Peters hints at a way out of this difficulty when he remarks: 'Of course such a man might understand and still be more attracted to something else of comparable quality. A mathematician might find himself drawn more to music and philosophy.'2 But to concede this is to reject the claim that to grasp the point of an activity entails being

1. Ibid., p.161.

2. Ibia., p.147. 
committed to its pursuit, and this is surely the most sensible move to make here for part of the point of exploring the whole range of theoretical activities is that it enables the explorer to discover in which area his own aptitudes and inclinations lie. He cannot possibly know this in advance of experience hence he is obliged to examine them all. But this is putting it much too strongly, for if our selfquestionex is powerfully attracted to the first activity which he encounters then what reason can he have for examining others? Presumably that he may be even more strongly attracted by another one of them once he understands what it is all about. But this is scarcely likely to carry much conviction with a man who, having gone deeply enough into mathematics, say, wishes to spend his time pursuing it further. It would seem to such a man that he has found the answer to his question and it would be very difficult indeed to convince him that he should set on one side his desire to pursue his interest in mathematies in order to examine what history, music and philosophy have to offer. This is a purely psychological point, but even if it is put on one side there is still the problem of finding a justification for hin continuing the search for worthwhile ways in which to spend his time when he already knows how he wishes to spend it.

This suggests that there is something artificial 
about the way in which the problem is set up for we would not in fact proceed with this endless quest once we have found what we are searching for, nor is it easy to see any point in anyone so continuing. Having found what we want to do we get on and do it. But this is not what Peters is seeking to jugtify: he intends his argument to justify both the full range of theoretical activities found in educational

curricula and the initiation of others into all of these activities. He therefore wants his argument to disellow individual choice before all the possibilities have been explored, and this it fails to do since it can only get going if it is assumed that his 'serious questioner' is willing to continue his search with an open mind until all the possibilities have been exhausted. Such an assumption is both psychologically unplausible and impossible to justify. Furthermore, the entire argument purports to be a justification of curriculum activities arrived at independently of what currently features in the curricula of educational establishments, yet the acceptability of the status quo is assumed throughout the exgument. This is mogt in evidence in the following prssage:

... no reason has yet been produced to show that the pursuit of science or art is any more worthwhile than playing golf or bridge, which share the character of being disinterested, civilized and skilful pursuits. Yet it is the former rather than the latter types of activities which feature on the curriculum of schools and universities. I 
The main (although unavowed) purpose of the argument thus appears to be the justification of current practice rather than the establishment of some guidelines for curriculum construction. If this is so then it helps to explain the air of axtificielity that hangs around the notion of someone asking himself how best to spend his time: anyone who puts this question to himself in the sense given to it by Peters already has the answer: '... such people are the products of an effective education, not its raw materials.' l liost people have little doubt about how best to spend their time, given suitable opportunities to exercize their interests. For exemple, those who spend a great deal of their time in thinking about soccer, arguing about it, watching their local team and avidy reading newspaper reports about the events of the previous Saturday, know what they want to do. How could such people be persuaded even to raise the question 'Why do this rather than something else?'? And what justification could there be for trying to get them to explore different types of activity when they are already gripped by an all-consuming interest? In schools the answer is simple: we resort to coercion by forcing children to attend regularly and compelling them to follow the prescribed curriculum. Those who run educational

1. D. Arnstine, 'Review Article -- The Cartography of Education: R.S. Peters' Ethics and Education', Educational Theory, XVIII, 184-194, 1968, p.188. 
institutions know what is worthwhile and do the best they can to communicate their own interests and enthusiasms to children in the hope that they will come to share them: to judge by the interests of most of the adult population these efforts must be judged remartkably unsuccessful. This is no reason for giving up the attempt but we ought at least to be honest about what we are doing in education and admit that our notion of worthwhileness is closely bound up with our own interests. ${ }^{1}$

\section{I have suggested that Peters' argument for}

theoretical aetivities amounts to a vindication of the status quo as far as the curriculum is concerned. It is worth pointing out that his whole approach to the problem, even allowing for the fact that it is explicitly restricted to the justification of theoretical curriculum activities, typifies a view of what is educationally valuable which is dominated by a concern for the cognitive, the literary, the theoretical, the traditional content of the curriculum. Almost nothing is said about action, about practical activities, about the satisfactions to be found in craftsmanship, physical effort, feats of endurance and exploration, and so on. Many people find these to be eminently worthwhile yet they are usually very peripheral indeed as far as most

1. This was discussed earlier in chapter II under the heading The University and the Pursuit of Truth.' 
of our educational institutions are concerned: an excessively intellectualistic view of worthwhile activities, and of education in general, not only produces notably unsatisfactory results in terms of achievements but it is also inconsistent with a concept of 'education' which covers aspects of personal development other than those relating to 'training the mind.'

But this is not an objection to Peters' arguments in favour of theoretical curriculun activities; the main objection to those is that they do not convincingly establish that curricula must offer a broad range of theoretical inquiries in order to promote the breadth of interest and understanding which we associate with the concept of 'educated person.' Is it possible to develop an alternative line of argument which will justify a curriculum which requires the gtudent to study areas of knowledge other than those to which he is initially strongly attracted? I shall argue that this can be done by making use of the rauch-abused notion of 'education for democracy.'

First, it is necessary to outline what minimal demands are made on its members by a democratic society in order that its political strueture may merit the description 'democratic'. The account of 'democracy' developed by Benn and Peters rejects the notion of majority rule as the basic defining characteristic of democratic institutions and pro- 
cedures and relies instead upon the principle that $\ldots$ governors should periodically satisfy a majority of electors in order to remain in authority, 1 This, in turn, rests upon the assumption that those who rule be required to provide rational justification for their policies and actions: 'An important difference between democracy and mere "majority rule" is precisely the assumption underlying such consultations, that reasons must be given for governmental policies. ${ }^{2}$ The description 'government by discussion' can properly be applied to democracy '... in the special sense that the whole process presumes the give and take of criticism and justification, conducted within the framework of moral criteria., 3 It is concluded from this that:

'Freedom of discussion is thus ... a condition for democracy itself., 4

Unless democracy is to be a mere facade concealing an autocracy then clearly it will not be enough simply to make freedom of discussion and critical argument available

1. S.I. Benn and R.S. Peters, Social Principles and the Democratic State, London, Allen Unwin, 1959, p.337.

2. Ibia., p.352.

3. Tbid., p.352.

4. Ibid., p.352. 
and unrestricted since this would be nothing more than an empty gesture unless the governed were able to engage in such disoussions. Consultations between rulers and ruled, if they are to mean anything, require the electorate to be knowledgeable and able (and willing) to take part in 'the give and talse of criticism and justification." This point is noted by Benn and Peters when they consider the objection that democracy is impracticable because it demands qualities which the ordinary man cannot possibly be expected to possess: the judgment of most electors on, say, the finances of a state superannuation scheme ox on credit policy, is not likely to be worth much, and there is no reason why a government should be expected to defer to $i t .1^{1}$ This ney well be, since the understanding of such problems requires a high degree of specialist knowledge, but not all public issues are of this kind and it is odd to find these placed in the same eategory as such abstract specialisms as nuclear physics.

Even on issues which affect the bulk of the people, it is unusual to find as many as twenty per cent of them sufficiently concerned to form any definite opinion. This is not surprising, for unless we have a personal or professional interest in a subject, we are not likely to know or care much about it. Why shoul. we expect the layman to form opinions on complex social and economio questions, when we take it for granted that his views on nuclear physics will probably be worthless?

1. Ibid., p.341.

2. Ibid, p.337. 
The answer to this is that such issues deeply concern the layman in a way which nuclear physics does not: they largely determine the form of society in which he lives and he would thus be very foolish indeed to leave all such issues to be resolved by experts equipped with technical knowledge. And unless he is able to form opinions and acquaint himself with what is involved in issues of social policy then he will be incapacitated from participating in the critical discussions upon which democracy rests. Indeed, unless he takes an infomed interest in such matters he will not even be able to take part in the minimal consultation process which is afforded by elections. In order to be anything more than a charade organized by a ruling clique in consultation with a few powerful interest groups democracy demands that the electorate be equipped to understand, criticize and help to form policy. The fact that few people are at present oapable of doing this largely results from Inadequacies in the educational system and can thus be changed in future: we are not obliged to accept widespread ignorance as being simply a fect of life to which democratic institutions must accomodate themselves as best they may. No such accomodation is possible since a democratic society is not viable unless a large majority of its members are able to participate in decision-making from time to time and 
to evaluate the actions of the rulers on the basis of knowledge and fimly held opinions.

If preparation for this kind of political activity is one major task of an educational system then it clearly suggests some guidelines for the curriculum. For one thing, it rules out an educational programme conceived in terms of specialized knowledge and skills since a man who was familiar with only a very restrieted range of knowledge would not be able to evaluate government policies and contribute to the rational critical discussion of them. He would be the victim of other experts whose proposals and decisions he would be unable to understand. The wider his knowledge the more readily would he be able to examine issues which depend largely upon questions of fact and distinctive forms of reasoning. For example, if his local council arranged a referendum on the issue of whether the water supply should be fluoridated then some knowledge of scientific procedures would enable him to scrutinize expert evidence, to detect purely emotive arguments and to arrive at a more reasoned decision then would have been possible had he been totally ignorant of science. One thing is abundantly clear: democracy cannot function if most of the citizens are ignorant since there would then be no possibility of informed and responsible discussion. A failure to prepare people for such disucssions is as undemocratic as placing a ban upon 
them; any democrat, therefore, is bound to do all he can to maximize educational opportunity and to ensure that educational programmes are sufficiently broad in scope to provide a preparation for critical discussion of the major types of political issue with which the student will be confronted during his adult life.

But even if the curriculum is structured so as to achieve this objective there remains the risk of developing a form of understanding which relates only to explanation and ignores the need for action: this is the academicism which was attacked at the end of the previous chapter. Preparation for democratic action demands more than knowledge on a broad front; it requires the development of a commitment to action based firmly upon understanding and values. Wuch educational theorizing and practice is dominated by purely intellectual values and an ideal of neutrality and objectivity mediated through explanation and expressed in a life of contemplation uninfected by any demand for action. Higher education, for example, if it is conceived at all in terms of 'education for democracy' concerns itself only with promoting some understanding of the history and 
workings of democratic institutions. ${ }^{1}$ There is no suggestion that students should actually do anything as a result of their studies: looked at in this way, student apathy should be taken as evidence of the success of the programe since it indicates that the students have become committed to the academic ideal of dispassionate objectivity? This view permeates the entire educational system and is evident everywhere in the schools' excessive concentration upon knowledge at the expense of intelligent action. ${ }^{3}$ At a

1. 'Te are a university devoted to liberal and general education, and we operate on the premise that all specialists should have a foundation of education which provides some understanding of themselves as persons, some understanding of the political system to which they profess allegiance, some understanding of the world in which they live.' Mi.G. Ross, The New University, Toronto, University of Toronto Press, 1961, . 25. The reference is to York University, Canada.

2. This often comes out in newspaper correspondence columns when student agitation and activism is denounced in such terms as: They are there to study, why don't they get on with it instead of causing all this trouble? In other words, academic study is seen as being completely disconnected from life and as having nothing whatever to do with providing the conditions required for the effective working of democratic institutions.

3. Scheffler has pointed out that teaching someone how to do something is not sufficient for teaching him to do it. In teaching of tizenship, he says, our aim is '... not merely to teach pupils how to be good citizens.... We talk of giving them "the skills required for democratic living", when actually we are concerned that they acquire democratic habits, norms, propensities.' I. Scheffler, The Language of Bducation, op. cit., pp. 98-99. 
recent meeting of a curriculum planning group assigned the tasis of constructing a new teaching scheme based upon the topic of democracy for fifteen year old school leavers, the first suggestion was that it should take the form of the History of the Idea of Democracy from Ancient Times to the Present Day.' Here was academicism rampant, determined to be theoretical, abstract and gafe. Any hint of the possible desirability of involving children in genuine democratic decision-making in order to help them to grasp some of the potentialities of cholce and action inherent in democratic institutions was rejected as belng both impracticable and undesirable. 1 Similarly with recent developments in higher education which have resulted from firnly-pressed student demands for a greater say in the runing of educational institutions: nobody supposes that the cautious concessions which are currently being made would have come about if students had not engeged in a good deal of militant action. Yet a fuller participation by students in both the teachinglearning process and in the administration of institutions

1. In a recent book which purports to offer exciting new guidelines to this area of the curriculum it is recommended that children be encouraged to engage in 'democratic debate' which 'should be concerned with real problems whenever possible.' These appear to be restricted to the need for boy-scout-type activities designed to assist the indigent: the political structure of the classroom, school and society is not even mentioned as a possible topic for discussion and action. R.G. Cave, All Their Future, Harmondsworth, Penguin Books, 1968, p.99. 
would seem to be demanded by any educational programe which claims to be a preparation for 'oitizenship' or 'democratic living.' It is ironic indeed when teachers in schools and universities have to be prodded into meking long-overdue reforms by those whom they are supposed to be initiating into worthwhile forms of life.

Specialization

Two lines of argument have been examined in an attempt to justify a broad curriculum designed to promote the wide range of attainments suggested by the achievement word 'educated'. Having raised some objections to Peters' defence of theoretical curriculum activities $I$ then developed a line of argument centred upon the implications of the notion of 'education for democracy.' Both of these accounts support a broad-based curriculum but the second of them has the advantage of connecting directly wi th the concept of 'personal development' discussed in chapter $\nabla$, and It also dispenses with some of the unplausible assumptions which Peters' argument seems to require. Both of these views, however, are incompatible with a curriculum designed to produce the 'mere specialists' deplored in the Robbins Report. Yet anyone with even a sight acquaintence with Tnglish educational prectice will know that curricula rest upon a very different educational theory from the one put forward here, namely, the doctrine of study in depth and 
the dogma of 'The Specialist'.

One of the most remarkable features of the Inglish educational scene is the astonishing extent to which the universities and secondary schools are committed to highly specialized studies. It is standard practice for children to be required, at axound the age of fifteen, to specialize in three or four subjects chosen either from the sciences or from the humanities. And if they go on to the university they commonly spend most of their time there pursuing one of these subjects to a very advanced level. It is thus thought perfectly proper for a graduate to have had no acquaintance with science, or literature or history since he terminated his elementary studies of these subjects six or seven years previously. Such a deep comitment to the merits of specialization clearly betokens widespread support for its 'educational' advantages and, indeed, it is easy enough to find people who can see nothing whatever wrong with it. 1 But in recent years there have been signs that educational theorists (and others) are becoming uneasy about a system which feeds children and students such a

1. 'However we seek the benefits of wide education, one thing is certain. We shall be utterly irresponsible if we destroy the best feature of our secondary education, namely, intense sixth-form specialization.' $\mathrm{K}$. Noreross, letter to The Iistener, 29 June 1967. 
stringently restricted diet. ${ }^{1}$ The schools have tended to place the blame for it upon university entrance requirements and theix highly competitive neture; the universities have explained the narrow range of interests displayed by many undergraduates by pointing to the confining nature of sixthform curricula. Neither side has examined its own activities in terns of what is intinated by the concept of 'education.'

With the recent establishment of a number of new univergities some of those who were seriously concemed about the educational consequences of specialization were given an opportunity to draw up entirely new curricula in ordex to correct what many people were coming to see as one of the worst defects of the Inglish educational system. The results, unfortunately, have been gravely disappointing; they have revealed $1 i t v 1$ e evidence of fresh and vigorous thinking and have only confimed the remarkable extent to

1. A measure of the anxiety which is being felt is the fact that in a single year three reports have been published which stress the dangers of a highly specialized programme of education. See: Inquiry into the Mow of Candidates in Science and Technology into Higher Education, Dainton Repoxt], London, H. . .0., 1968; the 1.0W into Employment of Scientists, Bngineers and Technologists, [Swann Report], tondon, H. S.0., 1968; M.C. McCarthy, The Employment of Highly Specialised Craduates, Soience Polioy Studies Mo. 3 , 
which educational theorizing in Ingland is comitted to the dogma of 'the specialist'. That advances there have been are of a very limited, cautious and essentially conservative kind: there is little evidence of radicalism in the curxiculum planning of the new universities.

To support this judgment I shall look first at the way in which the planners conceived their task; I shall then examine the ways in which they tried to solve the problem as they saw it. The plans made at the University of Sussex provide a good example with which to begin: the academic development plans for this university were given a generous amount of publicity, ${ }^{1}$ and as they were the first in the field what was decided at sussex tended to influence what was aone in the other new universities.

The major task was seen to be that of combating excessive specialization:

The familiar antithesis between 'specialized' and 'general' education was rejected: both specialization and general education were seen as essential parts of a balanced university education. An undergraduate would be expected not to study a multitude of unrelated subjects side by side or one after the other, but continuously to relate his specialized study to impinging and overlapping studies. Thereby, it was

1. The complacent tone of some of this could scarcely be counted as a hopeful portent. The Vice-Chancellor, for example, said: 'I believe that, on the whole, in educating our young people between the ages of thirteen and twenty one, we are working on the right lines.' J.S. Fulton, 'The Tuture Dattern of University Edueation in the United Kingdom', Journal of the Royal Society of Arts, CIX, 1961, p.853. 
felt, he would become not only an educated person but potentially at least, a better specialist. 1

The proposal to unify the traditional departments into a small number of schools was seen to follow from the educational premiss: 'Specialized knowledge was to be acquired in such a way that the boundaries of subjects were to be explored - and crossed - as well as the central territories.' 2 This would be facilitated by grouping disciplines into Schools.

The University of York follnwed Sussex in this respect: 'In order to avoid intense specialization there is no rigid division into faculties....3 so did the

University of Bast Anglia:

The academic programe of the University sepresents en effort to guard ageingt the dangexs of excessive specialization in undergraduate study .... The policy is to combine subjects and to organize courses in such a way that a considerable degree of traditional specialization in a chosen subject is possible, while at the same time the student is required to become acquainted with wider but related fields. 4

1. A. Briggs, 'Drawing a New Map of Learning,' in D. Daiches (ed), The Idea of a New Univergity, Iondon, Deutsch, 1964, p. 63 .

2. Ibid., p.61.

3. University of York: 1967-8 Prospectus, p.13.

4. University of East Anglia: 1966-7 Prospectus, p.25. 


\section{The University of Iancaster:}

... attaches importance to studies which cross the usual faculty boundaries, in the belief that in the present day an educated person whose main interests lie in the arts side should have some understanding of the methods of thought appropriate to science and a scientist should have a similar appreciation of the humanities. I

The University of Tent's prospectus says:

Thile it is true thet every undergraduate's chief concern must be with the syliabus of his chosen course, nevertheless the University attaches importance to the idea that each undergraduate should be actively encouraged to look beyond the intellectual confines of his main field of study ....2

The University of Esgex says of 1ts broadly-based first-year schemes that,$\ldots$ al though these schemes are designed to concentrate in depth on a narrow front, special efforts have been made to emphasise the linlcs between related fields of study .....3

It is clear from these quotations that the new universities felt themselves to be under an obligation to do something about what was seen to be the 'excessive specielization' which characterized the educational work of the older universities. It is equeliy clear that they mere not opposed to specialization per se, but only to the excessive lengths to which it was being carried el sewhere.

1. University of Lancaster: Prospectus 1967-8, p.23.

2. University of Kent at Canterbury: Prospectus 1967-8, p.1.2.

3. University of Essex: Prospectus 1967-8, p.15. 
Since they conceived the problem in this way, the very cautious nature of the steps which they took to deel with it is scarcely surprizing.

Most of the new universities decided upon an academic structure in which related departments were brought together in 'Schools' rather than Faculties: this, it was hoped, would encourage inter-disciplinary co-operation and halt the increasing fragmentation of knowledge which has been such a conspicuous feature of the system of autonomous specialized departments. Ignoring the recomendations of the Robbins Committee, they all decided against having general and pass degrees and opted instead for a 'corecurriculum' combined, in most cases, with a broad ilrst-year course. In practice, this usually means that students still spend most of their time studying a single subject, the 'core', and are not usually required to extend themselves outside of the broad area of knowledge in which the 'core' is located.

At Sussex, for example, all students must read a major subject together with related 'contextual' subjects. It is possible to combine some arts and science subjects, but the choice is extremely Iimited. At York there are a number of 'combined subject' options (two sub jects taken in equal combination) but these tend to follow traditional 
lines: it is not possible, for example, to combine history with chemistry. Only when a student opts for a main/ subsidiary subject combination oan he pursue interests in both arts and soiences. At Lancaster all first-year students study three subjects of equal weight and these, presumably, may be freely chosen. But for the second and third year they concentrate upon a rajor subject, al though they are strongly encouraged to choose, as a subsidiary, a subject which is quite new to them and which lies in e different area from that of their main interest. At Kent it is not possible for a student to cross the arts/science frontier: even in the first-year when he is obliged to study two or three subjects, the range of these is severely restricted. The same situation obtains at Bssex. At the University of Warwick, which seens much more conventional in outlook than the other new universities, there is a first-year course which all students must follow:

... in which the methods of the various branches of knowledge such as mathematics, the naturel and social soiences, liternyy critioism, ethios and politics are critically examined. Its aim is to give the student a critical sense of the basis and limits of his own discipline, and of its place in the universe of knowledge. 1

After examining the manifestoes ond curricula of the new universities. (I shall discuss the University of

1. University of Tarwick: Prospectus 1967-68, p.19. 
Keele later), one cannot but conclude that they are very firmly rooted in traditional concepts and attitudes and show little evidence of any serious attempt to deal with the real problem which is not that of excessive specialization but of specialization per.se. "They have mede it easiex for students (and staff) to cross the boundaries between disciplines, but only insofar as these disciplines lie within a single broad field of inquixy. Some of the common first-year courses represent interesting attempts to broaden the interests of students, but these are always seen as a preliminary to specialization which clearly remains as the paradign of higher education.

To understand the force of the drive towards specialization in English education it is necessary to consider some of the justifications which are comonly offered for 1t. A number of these are to be found in the following passage:

Universities have by tradition aimed at providing a liberal education in depth. Specialized study is thought necessary in order that graduates may know enough on leaving the university to take up posts in the professions.... Again, the intensive study of a limited field is held to be the best way, some would say the only way, of training the mind. It alone

1. For a similar conclusion see: A. Comme, 'Publicity or Promise: the New Universities', Delta, No. 34, 2-19, 1964. 
allows a student really to come to sxips with a subject. And it ensbles him, in company with his teacher, to tackle difficult and exciting problens at the very limits of contemporary knowledge. 1

The flrst of these contentions, although undenlably true, 1 only acceptable as a model if one tokes the univergities to be concerned with professional training rather than higher education. Study in depth is thus Justified as being necessary to equip the student to do a certain job. But if we are to distinguish between education and vocational training then this cesses to constitute a justification for specielization within education. Sloman's second point has more relevence to elucation since it is obviously true that to uncerstend a subject it is necessery to 'go into it' rather then travel superficially over its gurface. But there is no reason to suppose that the kind of understanding being eimed st in education cannot be aecured in a number of different subjeots at the same time, provided that these ere taught with this object in mind, that 1s, by judiolous and stringent selection of subject-nattex with a view to illuninating the logical and concepturl. structure of the discipline. To engender a grasp of the se suruoturas is what wo mean by 'training, the mind' in each of the major areas of knowledge. This is specielization in

1. A.Z. Sloman, A Univergity in the Maling, London, B.B.C. Zublications, $196 \overline{4, \mathrm{PD} \cdot 36-7}$ 
a non-vicious sense; that is to sey, the sense in which the student is enabled both to arrive at a measure of understanding and to extend his ow intelleoturl powers to the limit and so discover the extent and focus of his capacities and interests. This point was well-put by the Franks Comission: The Honour Schools were devised to provide education in depth. As we understend it, this in oxford has not meant going down deep into the subject until it is exhausted: the depth to be plumbed wes in the man himself'. 1 There is no need to spend three years in the study of a single subject in order to make this kind of discovery: it can be made by pressing hard at particular problems in a variety of different areas of inquiry. Neither is it necessary for students to be taken to the frontiers of knowledge before they can encounter difficult and exciting problems: all new problems are difficult and they can all be made interesting if presented in the right way.

The remaining justification for specialized studies is that it is only through them that students can be brought to the point at which original work becomes possible; for, it is thought, unless this point is reached we shall be unable to identify those students who are potential scholars and research worlsers. This seems highly debatable in

1. University of Oxford, Report of Comission of Inquiry, vol. i, Oxford, Clarendon Press, 1966, para. 244. 
itself and very questionable as a justification for obliging Q11 students to go through the same course when very few of them are going to become scholers. Any university teacher with a modicum of experience of worling with undergraduates should have little difficulty in identifying those with a capacity to go on to more advanced and independent work. This really lies at the heart of the problem of specialization in the universities: their educational activities are largely shaped by the conviction that their educational task is to identify and train future scholars and other specialists. This, in foct, is what the universities do -- and they do it very well. But one purpose of this thesis is to argue that this is precisely what they ought not to be doing. The Robbins Report, in its discussion of the curriculum, revealed very clearly the prevailing concern with professional training and the preparation of future scholers. It correctly pointed out that specialized training is essential if these aims are to be realized; but it also identified such training with hi gher education as the following paragraph 'shows:

Thexe are unquestionably young men and women for whom study that involves penetration in depth is naturally appropriate. They are eager to get to the heart of the subject and to develop powers of rigorous analysis and observation within its ambit. For such students

1. Comittee on Higher Bducation, Higher Education: Report, London, H. II. S.0., 1963, para. 258. 
the specialist first degree courses provided in the universities of England and Waleg are en admirable education, ... and we should add that the suitability of this training is not necessextly confined to future academics and high professionals.

\section{This is the paradign of higher education in}

Ingland: brosder courses are provided either as concessions to less able students or because they are deemed to be a more useivl preparation for teachers and public servants. The movement towards broader eurrioula is not primarily motivated by educational considerations but rather by the need to make gestures towards the growing dissatisfaction expressed by many students with what they axe offered by the universities, and a feeling that excessive narrowness makes for inadequate specialists. 1 the new universities have not demonstrated that they are working towards any new conception of higher edusation. ${ }^{2}$ They are as committed to the value of specialization as the other English univexsities: they have not set out to abolish specializetion but only to reduce it somewhat in the service of professionalism. Their Innovations do mark an advance, admittedly, even if they

1. The reports oited at the beginning of this section see excessive specialization ag a hindrance to economic productivity and a wealuess in professional training; they show little awareness of its educationel inadequacies.

2. For a purely descriptive account of the early curriculum planning $\mathrm{e}^{t}$ the new universities sees 16,3 , Campbell, Nonspecialist Study in the Undergraduate Curricula of the Tew Universities and Colleges of Advanced lechnology in England, Ann Arbor, Michigan, University of llichigan Sohool of Education, 1966. 
were undertaken for the wrong reasons, but this is small recompense for the failure to construct a gemine educational programme.

Al though the curriculex experiments at the new universities are disappointingly unimgginative and cautious, there is nevertheless one university anong those founded since 1945 which has made a genuine attempt to develop an educational programe which satisfies all of the criteria required by the concept of 'eduoation'. The University of Keele has tried to develop courses which will introduce students to all of the mein areas of intellectual inquiry. During the first year (the 'Boundation Year') every student attends a carefully articulated series of 230 lectures designed to provide some understanding of 'the broad context of human knowledge.' In addition, each student attends courses selected from the humanities, the social sciences and the natural soiences. During the next three years (it is a four year course) a student must study two main subjects for three years and two subsidiary subjectis each of one year's duration. At least one of these must be a discipline within the natural sciences, and at least one must be chosen from the humanities and social sciences combined. The science option chosen by non-scientists always involves some practical work in laboratories. 
This curriculum, al though defective in many ways, comes oloser than that of any other university in Bngland to the ideal educational programe, if only because it requires all students to gain some Pemilierity with both science and the humanties. It has the further mert of obliging students to study two main subjects instead of the eustomary one, but this advantage is qualified by the fact that these can both lie within the seme generel field of inquixy. By comparison with the other new univereities, the Keele currioulum still looks remerkably fresh and daring. It is not difficult to see close relationships between various conceptions of the university and the drive towaxds speciallzation in our educational institutions. If the university is seen as being essentially a centre for the puxsuit of knowledge for its own sake then this inevitably leads to highly specialized courses being provided for undergraduetes. To understand scholerly ectivity and to contribute to the sdvancement of knowledge demands detailed study of a restricted area of knowledge. This is reinforced by the competitive nature of the acadenic enviconment: in order to do well in examinations and to malre any reputation in the professton of scholarship it is essential to restriot one's interests and avoid the dissipation of energies over a broed field wi thin which others will inevitably be more expert. The university's function as a centre of applied 
research carries similer implications for the training of future research workers. The same can be said of professional training: the attainment of professional competence in, say, medicine makes extremely onerous demands upon the student and leaves little fime for the exploration of other types of inquiry or for the discussion of more general. ideas, Specialization is essential for success in most professions. In order to seek guidance in curriculum construetion it is therefore necessexy to look to those views of the university which conceive it as a cultural centre and an institution of higher education: the second of these reguires a curriculum which is brogoly based and more student-oxiented then those which are currently offered in our universities.

But a curriculum provides only a broad framework within which educational processes can teice place: what matters most to the student is the quality of his experience of learning and his encounters with his teachers. Any examination of higher education must take account of these and attempt to bring out relationships between teaching and learning and the achievements picked out by the notions of training the mind and personal development. Por someone might say: 'The curriculun is all right, but the nanner in which you teach and the way in which students learn are quite incompatible with whst I take "higher education" to mean.' 
Learning

Before we can say any thing very useful about learning in higher education, especially the type of autonomous learning which university teachers consider so desirable, it is necessary to establish that learning is an activity rather than a process. In order to do this some fundamental exploration of the concept of 'learning' is requíred; I shall begin by examining the very broad definition of 'learning' usually employed by psychologists, then develop a more restricted account in terms of action rather than behaviour, and then apply this account to such techniques as hypnosis and conditioning which are often considered to be methods of learning. Pinally, some criteria for applying the concept 'learning' will be presented and related to the nature of learning in the context of higher education.

A typical psychological definition of 'learning' would be: 'Learning consists of a more or less pe manent modification of behaviour.' I shall argue that such definitions as this (they can be found in almost any text dealing with the psychology of learning) are much too wide to be of value in understanding the nature of human learning and constitute a serious obstacle to any clarification of the connection between teaching and learning. Consider the movements of an infant. At first they are random, a mere 
flailing of arms and legs, but eventually the child is able to raise its arm and grasp a toy. Are we to say that it has now learnt to raise its arm? It certainly appears to have acquired an ability to move its limbs in a co-ordinated and purposive manner, an ability which it formerly lacked. But can the term 'learning' be applied to the acquisition of such an ability by the infant? It is tempting to say that it can, because at one time it had no such ability and later it did have it; so something must have happened in between and what can this be but learning? But this is to say that raising an arm is a skill and it would thus make sense to ask 'How does the child do it?' No answer is available; indeed, this is a very puzzling question since we have no idea at all of how to move our limbs. We are able to make bodily movements, and some of us can tell a long story about neuro-physiological processes which explain how such movements are possible, but we do not know how to move our limbs in the sense of going through some procedure which results in movements. Perhaps the child carefully observes the random movements of its limbs and then tries to guide them in the light of these observations and its own intentions? But such a performance is far too complex to be ascribable to infants (al though it might fit a man attempting to walk again after a long period in bed) and in any case we only speak of guiding movements when we already 
possess the primitive ability to make a variety of movements at will. I Standardly, one is not guided by any thing at all when raising an arm: one simply raises it.

So to speak of an infant 'learning' the use of its limbs is to use the word 'learn' in a very different sense from its everyday use. The behaviour and movements of infants are to be explained not in terms of actions and the exercize of skills but in terms of physiology in the same way that we would offer an account of its digestive processes or eye-blinking reflexes. This point is sometimes recognized by psychologists when they use the term 'maturation' to explain some of the changes which occur in the behaviour of children; but all too often they make use of a virtually unrestricted definition of 'learning' which allows almost any change in behaviour to count as a consequence of learning and anything which results in such a change to count as an example of learning.

That the discussion so far has been leading towards is a suggestion which must now be made explicit, namely, that learning, like teaching, (but unlike digesting, breathing and growing taller) is an activity - it is something which we do rather than something which happens to

1. I am indebted to Melden for the notion of 'primitive ability' and several other points in this section. See A.I. Melden, Free Action, Iondon, Routledge, 1961, ch.7. 
us. It is a concept which is elosely related to our ideas of human action rather than to oux understanding of physiological processes. And to say that something is an activity is at least to say that it is undertaken with some end in view, that it has a point, that the intentions of the agent are important and that the nature of what he does is highly relevant to what he is 1ikely to achieve.

If asked what I am doing now it would be very odd of me to reply that I am engaged in keeping my blood temperature constant or in digesting ry last meal rather than typing or planning a method of persuading my bank manager to give me an over-draft. The oddity of replies of the first type lies in the fact that my blood temperature and digestive processes are not matters over which I have any control or influence and therefore nothing whatever that I do (however knowledgeable I may be about physiology) has any consequences as far as such processes are concerned. By contrast, typing and persuading bank managers are activities which are open to my engagement and in which my own efforts are essential to success. This distinction between processes and activities seems clear enough.

Suppose it were possible, as a result of taking a drug, to acquire the ability to speak Pluent French or to understand A level physics. Would the taking of such a drug 
constitute an example of learning? Or suppose that such accomplishments could be come by as a result of brain surgery or hypnosis, would we be willing to allow these to count as instances of learning? Recent experiments with animals and RNA have shown that these exarales are not altogether fanciful. If learning is to be viewed as an activity then these must be rejected as examples of learning, for it makes no sense to say that I am engaged in doing anything when I am under the influence of drugs of hypnosis. Whether or not a drug, a hypnotist or a surgeon can bring it about that I acquire a facility in a foreign language or a knowledge of physics does not depend in any way on any contribution to the process which I might make. Indeed, in most of such cases (and in all cases of so-called 'sleeplearning') I I would be unconscious and hence incapable of doing anything. I would not be aware of there being. anything to be learnt so it would meke no sense to speak of my trying to learn it. While under the influence of drugs or hypnosis it would be absurd to say of me that I was engaged in trying to master or understand a body of knowledge, grappling with a difficult problem or practising a sicill. The success of such procedures is entirely independent of any effort on my part and it would not even pre-suppose that I am aware of

1. See: F. Rubin (ed), Current Research in Hypnopaedia, London, Macdonald, 1968. 
the fact that I am about to acquire new knowledge or skills. It would be enough to be told to swallow a tablet, inhale an anaesthetic or relax while a hypnotist intones a tranceinducing formula. This is a very long way from what we understand by 'leaming' - it is also far removed from what we understand by 'teaching.'

It might be objected that some of these exarmles belong in the realm of science fiction: this cannot be said of conditioning, a procedure which has been widely used for centuries and the effectiveness of which has been amply demonstrated. Are we to call successful cases of classical. conditioning examples of learning? For reasons given earlier the answer must surely be in the negative, although it is worth looking more closely at what is at issue here. Consider the case of a man who has been conditioned to contract the pupils of his eyes in response to his own sub-vocal comands. I Contracting the pupils of his eyes is not something which the men does at will: he runs through a procedure in order to make them contract, Whereas when I raise my arm at will. I simply raise it by exexcizing a primitive ability: I do not make it rise by going through a procedure the consequence of which is that my arm rises.

1. I am indebted to Vesey's detailed discussion of this example: G. Vesey, 'Conditioning and Learning', in R.S. Peters (ed), The Concept of Education, London, Routiedge, 1967. 
This is the distinotion discussed earlier between raising my arm and my arm riging: in some cases my arn rises because I raișe it but in others it does so because someone forces it up or because a nervous disorder causes it to rise. But if I suffer from partial paralysis and am equipped with an electrically operated mechanical contraption which allows me to press a button and so make my arm $r i s e$, then this would clearly be an example (analagous to the pupillary reflex) of my runing through a procedure in order to bring about the rising of my arm. By contrast, it seems quite clear that in ordinary cases I do no such thing but simply raise my axm. Indeed, as was pointed out earlier, in the ordinery type of case it is very difficult to attach any meaning to the notion of making my arm rise since $I$ have no 1 dea of what to do in order to bring this about: I just do it.

A further reason for rejecting conditioning as being a learning procedure is that whatever one does in learning to do something must be something which one does: it cannot be a process like growth which simply happens, neither can it be a procedure (like surgery and hypnosis) which is applied to one by somebody else. Yet conditioning is an activity which only agents other than the subject can engage in: it makes no demands whatever on the putative learner. It makes no sense to speak of the subject in a pupil-contracting experiment trying to acquire an ability 
to contract his pupils in response to a stimulus other than bright light since nothing he could do would make the alightest difference to the success of the experiment. His mental and physical strivings are quite irrelevant.

So far only classical conditioning has been considered and this involves stimulus substitution in relation to a reflexive response. No argument is required to show that this is of minimal concern to educators since it is no part of their task to modify such reflexive behaviour as eye-blinking and knee-jerking. But what about those postPavlovian techniques known as 'operant conditioning' in which non-reflexive responses are 'stamped in' by being appropriately rewarded or 'reinforced'? It might be argued that since teachers quite often make use of such techniques then whatever results from their application merits being described as the consequence of learning.

Once again, in order to make a decision here we must appeal to the notion of the subject's 'wittingness'. If he is aware of something to be acquired and appreciates that his own efforts are essential for there to be any prospect of success then we are much closer to the central meaning of 'learning.' But if nothing more is meant than the stamping in of certain responses (as with Skinner's pidgeons, for example) then this does not differ in principle from the application of drugs or surgery. The 
varlous forms of operant conditioning could then be viewed a.s techniques which we fall back on when (normal) teaching and learning appears to be out of the question as in the case of very young children, animals and people suffering from some forms of severe mental 1liness (the work of Miss Irene Kassorla with catatonic schizophrenics offers a good example). Or even when we deem it expedient to save time and effort by employing methods which do not involve the rather laborious business of leaming.

Finally, the centrel concerns of educators are scarcely to be realized with the aid of conditioning or any of the othex techniques discussed here since thej cennot bring about either genuine understanding or genuine belief, for in order to understand something or to entertain beliefs much more is requixed than the ability to utter certain words or behave in a particular way. Understanding, knowledge and belief are all connected with the capacity to offex reasons, and it should be clear enough by now that someone who has been conditioned cannot be said to believe or lnow anything as a result: he simply responds in a particular manner to a particular stimulus. I therefore conclude that it is highly misleading to treat the techniques considered above as being examples of learning (ox teaching) methods. 
It is now possible to set up some criteria which need to be satisfied before we can say that learning, in the task sense, is taking place. As fax as the achievements associated with learning are concermed we want to be able to say something about the mamer in which these have been acquired, that is, we want to be able to determine whether Johnny is proficient at mathematics or making love as a result of his genetic inheritance, or his diet during childhood, or because of some inexplicable insight possessed only by a particular group of people - or on account of the fact that he learnt to do these things. To sey that someone is learning, then, is to say that they are engaged in an activity rather than being subject to a process or procedure. And in order to be able to say, truly, that someone is engaged in learning, it would seem that the following conditions need to be satisfied:

1. The subject must be aware of something to be mastered: a problem, skill, facility, list of words to be remembered, an emotion to be controlled, and so on.

2. He must also appreciate that success cannot be attained without effort on his part. Digesting is effortless, but learning is hard work.

3. He must make at least some effort to master whatever it is that he seeks to understand or be able to perform. 4. The effort which he makes must be in some sense 
relevant to the task with which he is confronted. If someone who claimed to be engaged in learning to drive a car spent his time reading a Sanslerit gramner then we would have grave doubts about whether he had grasped the meaning of 'learning.'

None of these criteria is satisfied by the methods of bringing about changes in behaviour which were discussed earlier. It might be objected, however, that these conditions are jointly too restrictive in that they rule out a good desl of what we would ordinarily be prepared to call 'leaming.' It is true that if these criteria are applied then it becomes improper to speak of infants, animals and machines learning, but I do not find this prospect alarming. Wuch more worrying is the possibility of it ruling out what is commonly called 'picking things up', the general description given to the very obscure process (or variety of processes) whereby we acquire all manner of things from our every day experience of life. But al though this is an interesting, important and (as far as I am aware) completely unexplored concept, its analysis is not required for the purposes of my argument since it is peripheral to the central meaning of 'learning' and there are likely to be very severe limitations upon the range and nature of what can be 'aceidentally' acquired in this fashion. It would be extremely unplausible to suggest, for example, thet we could 'pick up' an understanding of physics or philosophy or the ability to 
practise a complex skill -- and it is learnings of this kind that higher education seeks to promote.

\section{Teaching}

It is important to clarify our ideas about

'learning' not only on account of 1 ts central place in educational theory and practice but also because it helps us to gain a more adequate grasp of the concept of 'teaching.' Our understanding of the meaning of 'teaching' is remarkably primitive. Few professional teachers are able to say very much about the nature of the activity to which they devote their lives, and what they do manage to say about it is usually indistinguighable from the unreflecting observations of the man-in-the-street. Yet teaching is an activity in which millions of people engage, vast amounts of money are spent on the training of teachers, and a great deal, in human as well as cultural terms, depends upon the successful outcome of the educationel enterprize in which most teachers are involved. Furthermore, we are being confronted with new developments in what is called' the technology of teaching' and these have led to a good deal of 100 se talk about the 'teaching capacities' of machines of various types. In addition, students are becomingly increasingly agitated about both the nature and the quality of the teaching which they receive during their higher education, 
an agitation which often reveals a number of quite basic conceptual confusions. All of this indicates that it is no mere academic matter to inquire into the meaning of 'teaching" since it is only by getting clearer about this that we can make rational evaluations of educational transactions. I shall begin by attempting to identify some of the basic criteria to be satisfied before we are willing to say in a particulax case that what is going on is to be treated as an example of teaching. This will lead to a discussion of some of the evaluative judgments which are made of teaching performances, namely, whether they are competent, educative and successful. Some of the implications of the analyses of learning and tesching for problems in higher education will then be brought out. I shall begin by exanining Schefflex's account of teaching together with some of the exiticlsms of this which have been advanced by Miss Joan Cooper. 1

1. See: I. Scheffler, The Ianguage of Bducation, Springfield, Ill., Charles Thomas, 1960 , ch. 4; Joan Cooper, 'Criteria for Successful Teaching', Proceedings of the $\frac{\text { Philosophy of Education Society of Great Britain 1966 }}{1966 . \text { For further analy ses see: }} 5-18$, Green, 'A lopology of the Teaching Concept', Studies in Philosophy ahd Education, III, 284-319, 1965; A. Kaufren, Teaching as an Intentional Serial Performance', Studies in Philosophy and Education, IV, $361-389,1966 ;$ B.P. Komisar, Teaching:Act and Enterprise', Studies in Philosophy and Edueation, VI, 168-193, 1968. 
Schefrler proposes three criteria which must be satisfied if an activity is to count as an example of teaching: (1) there must be an intention to bring about learning, (2) the methods used must be likely to bring about learning, (3) the methods used must not be morally objectionable.

The first of these seems to ne to be the least contentious, for if there is no intention to teach then this disqualifies at once the activity in question as a candidate for 'teaching.' Miss Cooper argues, however, that there could be cases in which this criterion need not be satisfied. Her example is that of a man who goes to cézanne In oxder to learn how to paint even though he knows that Cézanne will do nothing whatever to help him.

Eventually he leaves $A i x$, achieves a reputation and professes humbly that cézanne was his master and taught him all he (the pupil) knows. Now, can ceranne be said to have been teaching this pupil when he was just painting and allowing the pupil to be there with him?. He can haxdly be said to have been trying to teach him. Perhaps he intended to teach him, but this only amounts to his not belng unwilling to allow the pupll to learn from him. A teacher may very well go about things in this way and yet be considered an inspired teacher. 1

\section{I do not think that this example will work, for} not being unwilling to allow others to watch what I an doing is not equivalent to teaching them to do what I am doing unless it is coupled with an intention to bring about 
learning. And to say that a teacher 'may very well go about things in this way' is to pre-suppose what is in question, namely, the attribution of intentionality, for otherwise we could ettach no meaning to whet it was that the agent was 'going about'. 'He taught me all I know' should thus be construed, in this and allied examples, as 'I learnt from him all that I know', and this does not carry any implication that teaching has taken place. It is true that axtists and writers often speak of having modelled their work on that of the great masters but it would be very odd to take this to mean that they had been taught by them.

Miss Cooper does not offer any examples of inspired teachers who have behaved as did cézanne in her 11lustration, but she may well have someone like Socrates in mind. Even if we disregard the explicit teaching episode, and it is an extremely problematic one, which involces the doctrine of anamneais in the Heno it might still be claimed that much of what Socrates did entitled him to be regarded as an inspired teacher. Supporters of such a claim could

1. Similarly, if at the end of a chess game with a 'master' I tell him that he has taught me a great deal about the game, It would be most peculiar for him to reply: 'Oh, I was teaching you was I? I thought that I was just playing chess with you, but you say that I was teaching you how to play a better game. I had not thought of myself as doing that, but now I see that that was what I was doing.' What he should have pointed out was that from the fact of my having learnt something it does not follow that he taught it to me. 
point to the fact (if it be one) that those who argued wi th Socrates learnt a grest deal about the meaning of ' Justice', 'knowledge' and 'truth' as well as improving their akill in argument as a result of discussiong with an expert dialeetician. But even if this were to be aamitted it would not estsblish that socrates was a tescher unleas it could be shown that he engaged in argument wi th the intention that others should learn those things, for tanless we insist upon this we shall be obliged to allow that every time we engege In argunent we also engege in teąching. This could be generalized to such an extent that we might be driven to saying thet anything which we do under obsexvation is an exarple of teaching. But when people engage in argument wi th others they standerdily intend conviction rathex than learaing to be the result. Then philosophers argue with each other they are not trying to teach anything to their colleagues, although a philosopher may very woll have the sane argument with ono of his students and olain that he was attempting to bring about learning. But in such a case the pedegogic intent would probably be manifested both in the way in which the argument was conducted and by the malcing of remexiks which would be irrelevant were the argument of mply intended to prove $s$ point. But this need not be so, for the gane ergument bould occur in eech case: 
the only difference between the two that is necessary is thet in the teaching situation there be an intention to bring about learning. This brings out the importance of intention as a criterion of teaching.

But to have an intention to bring about learning means very little unless it is coupled with doing something and this leads us to the second of Scheffler's criteria: the method adopted must be 'not unreasonably thought to be likely to achieve the learning aimed at, 1 This introduces an appraisal category (that of competence) whioh receives 1ittle attention from either Schefflex or Miss Cooper despite its erucial importance in teacher-training and the evaluation of teaching. The notion of 'competence' will be discussed later.

Scheffler's third critexion rules out some of the methods which meet his second criterion on the grounds that they are objectionable as methods irrespective of their connection with success: this has the effect of disqualifyIng such procedures es conditioning, violence, threats, co-ercion,lies, propagenda, drug-taling and hypnosis. But this criterion is formulated in terms of a rationalist model of teaching which, as Miss Cooper has pointed out, appears to be largely founded upon the experience of teaching philosophy to undergracuates and is scarcely applicable to

1. Scheffler, op. cit., p.68. 
the teaching of children or to the fostering of artistic and literary apprectation. According to this model, teaching requires us to reveal our reasons to the learner and to submit them to his criticism. If we accept this as the paradigm manner of teaching then we shall be foreed to refuse the title of 'teacher' to the many thousands of people who devote their lives to teaching young or educationally subnormal. children, learners who are in no position to exercize independent judgment upon what their teachers say. Any general account of teaching which forces us to this conclusion is clearly unduly restrictive and hence unacceptable. If we wish to rule out conditioning and hypnosis as methods of teaching then it would be better to do this by defining 'leaming' in such a way that conditioning, hypnosis and drug-taking will not count as examples of 1t; this I attermpted to do in the previous section.

If we are seeking only to give a general characterization of 'teaching' then we can dispense with Scheffler's third criterion since even if we disapproved of someone's methods this would not oblige us to deny that he was engaged in teaching. Some form of his second requirement, however, seems to be indispensuble even though it forces us to make a difficult and obscure distinction between teaching incompetently and not teaching at all. If 
we accept that teaching involves trying to bring about Leaming then the putative teacher must be doing something over and above intending to do something, and this activity mugt be in some way relovant to the intention for we would not be willing to allow any activity to count as an example of teaching. Scheffler's discussion of this problem does not appear to permit a distinction between teaching incompetently and non-teaching. He says, for example, that:

If Jones is engaged in teaching, he is, then, trying. It is clear that to be trying to do something is not al ways to succeed. Whether success is also attained depends on fectors outside of one's trying: the universe must co-operate. To hunt lions is to try to bag a lion, whereas to bag one is also to succeed, I in this attempt, and depends on more than just trying. 1 He then goes on to argue that it is a mistalce to suppose that thexe is any tacit reference to success in such statements as 'Jones is engaged in bagging lions' and would presumably want to say the same thing about 'Jones is engaged in teaching'.

This is very puzzling, for I do not see how we can make any sense of the clain that someone is trying to bag lions unless there is gome reference to success, that is to say, unless there is some possibility of him aotually bagging one as a result of what he is doing. One cannot be said to be engaged in hunting lions if one sets out on a saferi to Antaxtica or lies conclealed, gun in hand, underneath Wigan Pier. To categorize an activity as being of a

1. Scheffier, op, cit., pp. 68-9. 
certain kind such as hunting, fishing, navigating or beaching involyes assexting that what is being done bears some relation to success, for if there were no such relation then the activity in question would not nerit the description and we would heve to rest content with saying that whatever it was that was being done it was not hunting, fishing, teaching, and so on. In other words, we would be Iimited to negative descriptions sinee we would feel at a losg to say just whet it was that was being done. 1

This suggests that we need to be able to distinguish between non-teaching (unrelated to success), incompetent teaching (weakly related to success) and competent teaching (strongly related to success). The contrast between competence and incomptence can be seen more clearly by considering the example of a 'demonstration lesson' in which a student teacher (or an expert) shows that he knows how to teach, say, long division to eight year old children. ${ }^{2}$ Such demonstrations can be given without any children being present and the question of success is thus

1. For discussions of this problem from a general viewpoint, see: F. Broadie, 'Trying and Doing', Proceedings of the Axistotellen Society, IXVI, 27-40, 1965-6; A. Cody, TCan a Single Action have Many Different Descriptions?', Inquiry, $\mathrm{x}, 164-180,1967$.

2. For an interesting treatment of activities which share 'intention-perasiti sm and circumstance-detachment' see: G. Ryle, 'Thinicing and Refleoting', in G. Vesey (ed), The Human Agent, London, Nacmillan, 1968, especially pp.221-223. 
ruled out entirely. By the same token, there can be no Intention to teach either. That is boing demonstrated is that, given standard conditions, the student lenows how to teach the proposed subject-mattex. Whether the perfomanoe will be judged competent or not will depend upon the extent to which he makes effective use of methods which are known to be associated with the promotion of learning - - even though, in this case, success and failure are ruled out as far as learning is concerned since there are no learners present.

The distinetion between teaching and non-teaching is much more troublesome. One way of sherpening it would be to look closely at particular teaching episodes and try to Identify theix major chaxacteristics. Such a semutiny would presunably yield a list containing such iteras as: explaining, directing, correcting, admonishing, questioning, encouraging and waming. But policemen also do all these things and they are not teachers. It would therefore be necessary to examine the nature of the explanations which teachers give, the kinds of things that they explain and their purposes in giving explanations. Observation of teachers at work, important (and neglected) though it is, would not be enough however; we would also have to discover what teachers think of themselves as dolng, what they hope 
to achieve, and how they perceive these as being related. That, then, can be offered in the way of a general description of teaching? Very little, it seems, beyond saying that there must be an intention to bring about learning together with an engagenent in activities which are relevant to the realization of the intention. If this appears unhelpful we should not be surprized: teaching covers such a wide range of situations and tasts, and involves so many very different individuals as learners and teachers that we can only give it content when we get down to cases. We have to ask, in other words, who is teaching what to whom? Another reason for concluding that highly general definitions of teaching are likely to be unhelpful is that they are only very weakly related to the notion of teaching-success. I shall now try to show why this is so. The discussion so far has provided four categories which can be used to describe and appraise teaching: (1) teaching simpliciter, defined as an activity which is In some sense relevant to the task of bringing about learning, (2) competent teaching, defined as an activity which is known to be reasonably likely to bring about learning, (3) educative teaching, defined as an activity which involves the use of only those procedures which are morally acceptable in order to pass on knowledge and skills which are valuable, (4) successful teaching, defined as that 
activity which results in the desired learning taking plece. Before examining an activity in the light of these criteria it is first necessary to settle the question of intention since if there is no intention to bring about learning then whatever is going on cannot be an example of teaching. It is clear that the first three, elther singly or jointly, do not entail the fourth: the best of teachers often fall to bxing about learning but it does not follow from this that they have not been engeged in teaching. 1 Leerning cen also occur in conjunction with incompetence, and even as a conseguence of it if we accept the evidence of 'compensation' by pup1ls. Learning can also occur when (3) is not setisfied: whet Fegin did was not educative but he was undeniably a successful teacher. It looks as though the only logical relation which holds between these criteria is that (4) entails (1), an implication which is of little prectical value. As educational research becomes more effective the content of (2) can be expected to increase, but this will not reduce the problems generated by (3) and these are the source of most of the atsagreements in judging teacher-success. The reason for the contentiousness of the thixd criterion is that when it is unpackod it will

1. G.Il. Bantock, if I understand him exight, identifies 'teaching' with 'successful teaching'. See his: Education and Values, London, Faber, 1965, ch. 8. 
be found to consist laxgely of stipulative definitions grounded in value judgments which are rarely made explicit. The question of competence, however, is largely an empirical one and ean be settled by appeal to the facts: this will not be a simple matter for the facts will be highly complex and will vary considerably from teacher to teacher, subject to subjeot, and learner to Learner. Educabionists often. stress the sophisticated character of the slcills required for teaching but one suspects that they are by no means fully aware of just how complex these are.

What this suggests is that we canot require more of a teacher then competence: we cannot justifiably ingist thet he be successful ell of the time, most of the time, ox even (perhaps) some of the time since circumstences may be heavily stacked against him. It might be objected that if we encountered a doctor who never managed to effect a cure or a lawyer who lost every case then this would lead us to deny that they were competent. But the doctor might be working with incurables or trying to cope with an unknown and deadly disease, and the lawyer might have chosen to take on only the most hopeless cases (as a chellenge to his powers) yet defend his clients brilliantly al though without success. Teachers also have their problems: recalcitrant children, inadequate worluing conditions and hostility from 
parents, for example. In eveluating a teacher's skills, therefore, we should restrict ourselves to asicing: 'Is he doing all that anyone could be expected to do in this situation?' If learning does not occur then the teaching has been unsuccessful, but it does not follow from this fact that the teacher cannot claim any achievements since he may well have conducted himself brilliantly yet still have failed to bring about leaming. In such a case a colleagre right say: 'Yes, I had the same trouble; it was too hot today for anyone to learn anything I suppose": or, 'Oh, it was $4 x$ was $i t$ ? No wonder you didn't get anywhere with that 1ot!"

So we cannot judge teechers solely in terms of the schievements of their pupils; we must try to give teachers their due in spite of their pupils. And in order to do this it is necessary to estimate the achievements of the teacher by attending to what he does rather than by concentrating upon what the leamers do. A further argument which supports the impossibility of defining tenchercompetence in terms of what pupils do is provided by the fact that in a given class some children leam while others do not, yet the teacher's actions have been the same with respect to all of the members of the class. So from the point of view of one child the teacher's performance is competent and successful, while from the viewpoint of 
another it is the opposite. This is absurd, so the notion of 'competence' cannot be tied directly to the achievements of leamers but must be viewed in relation to the achievements of teachers in exploiting their lknowledge and skill. to best advantage.

What do these conceptual inquiries into learning and teaching suggest in the context of higher education? Many of the most troublesome and important problems can only be solved by empirical investigation, but these questions cannot be gone into here. ${ }^{1}$ AII. that can be hoped for is some general guidance as to the character of teaching/learning transadtions at the level of higher education. One obvious point that emerges is the essentially aotive character of teaching and leaming, and this connectg readily with the concept of 'autonomy' proposed in chapter IV as the distinguishing objective and achievement associated with higher education. By definition, of course, the student must leem and think for himself, ${ }^{2}$ but it is only at the stage of higher education

1. See: J.P. Powell, 'Experimentation and Meaching in Higher Education', Educationel Research, VI, 179-191, 1964; 'Tutorial Neaching and the University Ideal', Australian University, IV, 19-36, 1966.

2. Presunably this is the point of Carl Rogerg' aphorism: '... no one cen teach anyone else any thing.' C.R. 'Rogers, on Becoming a Person, Boston, Houghton Mifflin, $1961, p .303$. 
that he is able to do this effectively wi thout the aid of teachers. ThIl autonomy implies a cepacity to works at intellectual, tasks, to deliberate on moral issues and, in general, to conduct one's own life without the assistance of others,

Another very obvious point is that tesching/ learning transactions are only possible when one party knows more than the other. Although this may appear trivial it is an assunption which is often questioned by students when they allege that much of the tesching in the universities is too authoritarian. It is sometimes said that a good deal of teaching encourages a very passive response from the learner in that he is required to absorb inert information rather than to involve himself actively in a process of questioning leading to genuine understanding. To the extent that higher education is viewed by the student as a right rather than a privilege then this is likely to change his whole attitude to the learning process.

The student who regards his study as a privilege or a meang of social mobilit ty is likely to be very passive towards the systen, to assiduously learn what he is told, never questionting its vglidity. In contrast, the student who takes higher education as a. $x i$ ght will responid more assertively. He will demand his 'rights', adopting a generally critical approsch to all he is taught or expected to lenow, 
methods of teaching, the content of courses, the entire system of exeminations will all be called into question. 1

This is rather an odd cladn: from the fact that

I have a right to higher education (or to any thing whatever) it does not follow even thet I shall choose to take adventege of it lot alone comport myself in a perticular way 1. I do so choose. On the contrary, if we have to pay for something it might be thought more likely that our expectaHons and demands will be higher then if we are simply given it s.s of $x$ ight. Whet Adelstein is doing here, in fact, is maicing the sociological observation thet meny students who cleim that higher education is a right rather than a privelege elso tend to be more eritioel of the curriculum, teaching methods and the power structure of the universities. Nevertheless it may well be true that, in genersl, an elitist and basically authoritarian educationsl system does tend to encourage a passive and acceptive attitude towards learning, an attitude which many academios have been quite

1. D. Adelstein, Crisis in Higher Eduostion: the Roots of Revolt', in D. Adelsteln (ed), Meach Youxself Student Power, London, Radical Student Ailiance, 1968, p.20. 
content to ignore. 3. But the encouragenent of an uncritical attitude towards whet is being taught and leamt, al though it may make for a comfortable peaceableness within the educational environment, is incompatible with the aim of 'training the mind' which is held to be one of the major objectives of higher education. If, as the Hale Report claims, 'the most importent purpose of a university education is to terch the student to think for himself', then this mugt imply far more than merely acknowledging the conceptual point that learning is en activity demending appropriate effort on the part of the student. It must at least imply that a serious attempt must be made to maximize the student's involvement in whatever he is studying so that he can make the material meeningful for him and develop a growing understanding of it. If by 'understending' is meant, in part anyway, an insight into underlying xationales end an appreciation of the force of particulax arguments and pieces of evidence end, in general, of ressons for beliefs (as was argued in chapter IV) then authoriterian teaching

1. Soxe have positively encouraged it, as did Todhunter in the nineteenth century: "If [a student] does not believe the statements of his tutox -. probebly a clexpyman of mature knowledge, recognized abili ty and blamelesg character - his suspicion is irrationel, and manifests a went of the power of appreciating evidence, a want fatel to his success in thet branch of science which he is supposed to be cultivat1ng.' J.l. Ziman, Public Knowledge, Cambridge, The Universi ty Press, 1968, quoted on p.63. 
metho ds will inevitably hinder the growth of understending. Unfortunately, it is not unoomon to hear university teachers acknowledge this verbally but fell to act accordingly.

\section{1.}

Students are becoming increasingly awaxe of the fact that the very form of mich university teaching reduces then to mere spectetors obliged either to accept or reject what they are told. The apathetic attitudes which this tends to engender are reinforced by the exrmination system which encoureges regurgitation, an uncritical and dull conformt ty of thought, and the production of safe answers. Nany find little of the intellectual excitement and 'clash of mind" which the public pronouncements of university people had led them to expeot. Small wonder that many of them feel badly let down.

This disappointment has led to the belief that if only the universities can be thoroughly 'democratized" then the teaching/learning situation will be transfomed and the authoritarian handing out of information and received points of view will be replaced by discussions in which teachers and taught will join together in the comon

1. 'Last sumer, I was invited to a secret meeting of Italian Maoist students: we listened to Jean-Paul Saxtre attacking megisterial. lectures by professors - in a professor's magisterial lecture that went on in respectrul. silence for $2^{1}$ hours.' R. Miayne, 'Views', The Listener; 31 Ootober 1968, p.570. 
task of advancing knovledge and understanding.

It is argued that while the structure of departimentel authority which pervades the leaming process remains, the means of understancting one's subject is distorted and interest is lost. Instead of the teacher facing the students, in a one-way process of instruction, the students want a two-way interchange. This involves the student in shaping the content and direction of the course and lecture with the teacher, enoouraging not only interest but al so creativity by both. 1

This is an invocation of the tradi tional ideal. of the university as a commuity of scholars and it is undoubtedy prompted by the feeling that the universities have alnost entirely abandoned this ideal in their pursuit of quite aifferent ends, a betrayal which is seen only too clearly in the widespread neglect of teaching and community 11fe. The gulf between teacher and taught is seen by students to be widening deily, and the quality of their 'offioial. intellectual. Iife is felt to be fatally impoverished as a result.

The Free Universities springing up all over the country are important here. For there is no distinction draw between teacher and teught; tho se who deliver the talks or lead the discussions may know more than the rest to begin with; but the process followed is of sharing lnowledge in equal parthership and of $a$ mutual and difficult effort to meke the vital comections. This is not just cant, even if it doesn't work all the tine. The heroes of the student revolt, Herx and Marouse, are people who've made this attempt themselves, and it is

1. D. Atkinson, The Case for Student Power and Student Rights', The Times, 1 october, 1968. 
significant that both are acadenies who used academic sources. That's shocicing is that students should feel their. intellectual life so empty when it's followed with those appointed to act over them. Surely there's something wrong with a university whose students only feel intellectually fulfilied away from the dons? 1

\section{Aayone who advocates the view that all}

dj.atinotions between teachers and learners should be abolished will have to abaidon the notion of teaching altogether and replace it with the concept of a joint enterprize of discovery and problem-solving, since where all are ignorant (or wise) none can teach. Indeed, such a view is pre-supposed by the very possibility of higher education succeeding in bringing students to the stage at which they can function as fully autonomous individuals. But the whole point of higher edueation is to bring students to such a

1. S. Ho ggart, 'Cambridge Anti-memories', The Guardian, 17 October 1968. Of course, not all students see the situation this way; some are more inolined to blame students than stafe: The main thing wrong with the department is the students. We have destroyed any concept of Bducation that the staf? have created. We have destroyed ourselves. We have destroyed onxselves by being apethetio. From the very first day we walked into the Schuster Laboratory we have been steam-rollered into apathy and bewildement by the very nature of the subject we study. Physies .... Wo opportunity has been given us to discuss our subject lor what 1 t is, why it is and where $1 \mathrm{t}$ 1. S. All xighb, you can blane the staff. I don't. They heve never been asked by the students for such discussion. I doubt il they will. A series of general lectures last year on soience and Politics was attended by six people. Six out of 300 andergraduetes.' I. Kernaghan, Apathy Amongst Physics Students, mimeoed document circulated 
state of independence and this in turn pre-supposes that they still require guidence and help in finding their way around their personal, social and intellectual worlas. The trouble is that often (and often unintentionally) this help is offered in unsultable forms and is then correctly perceived by students to be incompatible with the attainment of those schievements which the universities hold out to students.

There is a lallure of understanding and communication here on both sides. Students sometimes fail to appreciate such ideas as 'participation' and 'democracy' cannot be applied without limitation in intellectual contexts or in educational situations: arguments are not settled by counting heads, and standards of coxrectness and appropriateness in matters of scholarship are not open to dispute as are our social and political axrangements. In order to leam a sicill one simply has to acknowledge that there is such a thing as correct method of performance: mountaineers do not vote on the correct way of tying a bowline before entrusting their lives to a knot. Since this is so, the best way of learning to succeed at complex performances or to understand the force of subtle axguments or to conduct intricate experimentation and theorizing is to go to those who are skilled in such 
matters and try to profit from what they have to teach. Teachers, on the other hand, sometimes use the quite legitimate authority which their lnowledge confers upon them in ways which are totaliy unjustifiable: they are often remericably reluctant to allow that students are autonomous in any sense whatever and seen detemined to exercize a paternolism which will effectively prevent students from ever gaining the independence which they, as teachers, are allegedly fostering. I It is really a quite extraordinary situation when students have to resort to force to bring home to their mentors the prectical implications of what they publicly proclaim to be the objectives of higher education.

1. We adults destroy most of the intellectual and creative capacity of students by the things we do to them or make them do. We destroy this capacity above all by making them afraid, afraid of not doing what other people want, of not pleasing, of making mistakes, of failing, of being wrong. Thus we make them afraid to gamble, afraid to experiment, afraid to try the difficult and the unknown. Even when we do not create students' feers, when they come to us with fears ready-made and built in, we use these fears as handles to menipulate them and get them to do what we want .... For we like students who are a little afraid of us, docile, deferential students, though not, of course, if they are so obviously afraid that they threaten our image of ourselves as kind, lovable people whom there is no need to fear.' J. Holt, How Chilaren Pail, New York, Pitman, 1964, pD. 167168. I have substituted 'students' for 'children' in the original. 


\section{CHAPTER VII}

Conclusions

Twenty years have passed since Hoberly remarked upon the confusion of thought regarding the purposes of the universities, yet what he had to say still holds true today:

When we turn to the primary questions, concerning the things that really make or ma $r$ a university, and ask -- What are universities for? What effect should they have on their alumi? What are their responsibilities to the outside world?', we are asking questions to which a minority of university teachers record discordant answers and the majority return no clear answers at all. 1

Yet during the intervening years the number of university students has increased from about 60,000 to around 190,000 , a remarkable number of new universities have been founded, and novel forms of institution providing undergraduate work have come into being. Indications are that by 1980 there will be about half a million students in these snstitutions and the colleges of education, an increase in tha size of the student body which will transform the British higher education landscape beyond the wildest imaginings of such post-war critics of the universities as Moberly. Some of the foundations of this transformation already exist as a

1. W. Moberly, The Crisis in the University, op. cit., p.21. 
result of a number of majox policy decisions which have recently been made, decisions which (unfortunately) reflect the muddled theorizing and lack of clear purpose which so disturbed Moberly twenty years ago. The Report of the Robbins Committee, for example, had virtualiy nothing to say about the nature and content of higher education and was concerned almost entirely with questions of institutional organization and structure. Although its proposels were expansionist (even if conservatively so) these were conceived in terms of maintaining the supremey of the universities within the system of higher learning and they showed scant evidence of fresh thinking about eithex the structure of the system or the tasks with which it is confronted. The few remarkg made in the Report on the nature of higher education reveal the traditional view of university studies as being essentially speclalized in character and designed to foster initiation into a common learning and a shared set of values. Many of the present problems in higher education are the result of decigion-making based upon inadequate theoretical foundations. Iven where the theory might be thought to be reasonably adequate institutional practices are often out of step with the theory: there is an air of unreality about many current debates engendered by the lact that much of what goes on in universities is at variance 
with what is proclaimed by the defenders of these institutions. This gulf between theory and practice has been seen most clearly by those students who are demanding reforms throughout the entire system. In order to close this gap and bring what is done into line with what is said to be done it is essential to clarify the theories which allegedly underpin the practice. ${ }^{1}$ This thesis is an attempt at such a

1. Iven the casual observer of the contemporaxy university scene cannot fail to notice the gulf between proclaimed ideals and everyday realities since its consequences are everywhere apparent. As an example of student awareness of it the following sums up what many are coming to feel: We have been taught to look to the university for leadership, guidance and inspiration. Yet everywhere we see the university a servant of industry and government. We see the university unable or unwilling to fulfill its role of renewing those intellectual. and moral energies necessary to create a new society; one in which personal dignity and human community can be preserved. We see the university teaching those values in our society which if persisted will lead to a deepening of the present cxisis and the eventual loss of human dignity and freedom.... We are confused by the inconsistencies of principles in our univergities which degrade them and their position in society. We are told that we have a democratic society in which we can participate in decisions affecting us, yet we are denied the right in practice. We are told that the pursuit of knowledge should be free, yet in practice we are given the opportunity to learn only certain things. We are told that the pursuit of knowledge and the betterment of men are our prime gosls, yet our education is determined to a large extent by demands of the economy and job expectations. We decry the university legislating our morality and continually ignoring the problem of immoral use of knowledge in our society. Me are confused when people decry secrecy and depersonalization in society, yet themselves meet in secret." "We see the University a Servant of Industry and Government', University Affairs, $\mathrm{X}$, No. 2, 1968, p.11. This passage is taken from 8 document submitted to the president of the University of Victoria, Canada, by the president of the University's Alma Mater Society. 
clarification and it should therefore carry some implications for educational policy - or at least make plainer the bases upon which rational policies should depend. But before speculating about the future development of our institutions of higher learning I shall look again at the concept of 'higher education' in order to make my own view of it unistakable and to bring together some of the points made in earlier chapters.

\section{Hi gher Education Again}

In chapter III foux strands were ldentified in the concept of 'higher education': Intellectual training at an edvanced level; the passing on of what J.S. 1111 referred to as that which 'one generation owes to the next'; the production, in the words of the Robbins Repoxt, of 'good men and women'; and the development of 'persons.' It was later argued that 'education' should be viewed as a unified concept so that higher education could be seen as the culminating stage in the process, largely provided by the schools, of developing individual capacities for rational action based upon knowledge, values and attitudes which are worthwhile in that they contribute to (and are in large part constitutive of) the good life construed in both personal and social terms. In order to play an active part in a 
society founded upon democratic prinoiples it is necessary to be faniliar with the mejor problem areas with which political decision-neking is concemed, and this was used to Justipy the theoretieal setivities which comonly occupy the curriculum and to requixe a wider engagenent in these than is oustomngy at the present thine. Student demends for an education which is more socially orlented do not make sense unless euch an education is grounded in the disciplined knowledge which is required both for an understanding of social problems and for their resolutions chepter IV showed that the qualities of nind demanded of anyone who seeks to acquire and use this knowhedge ere elosely tied to particular ways of formulating and handing problens and are thus not posseased of unrestricted generality. This provides further support for a broad curriculun deaigned to develop these qualities of mind in a variety of contexts and to back them up with eppropriate lnowledge and sk111s. But more then this is needed if eluestion is to be seen as being concemed with encouraging propensities for action rether than as a preparation for a life of contemplation: unleas knowledge is to renain inert it must make a difference to what people do as well as whet they are. This 1 inlites that the concept of 'educated person' requires for 1 ts satisfaction someone who is able to hamonize his knovledge, 
his values and his feelings so that his actions are (moreor less) consistent with them: this problem was explored in chapter $\nabla$.

Now I want to make explicit an issue which has been alluded to in a number of places earlier and which is of the greatest significance for any account of higher education, namely, the extent to which education is to be constmed in terms of the production of 'rational man.' The received view of education in Britain would appear to be that the educational process is almost entirely directed towards an ideal of inteliectual excellence which conceives the good of man in tems of a life of contemplation devoted to the pursuit of knowledge for its own sake. Only social misfits and the feeble-minded are encouraged to seek other forms of life. The educational system is thus geared to the development of people who display those intellectual virtues which ean only be acquired through engagement in those specialized theoretical activities for which the universities have traditionaliy provided a home. The main point that needs to be brought out here is that the model of 'rational man'. on which the whole system is based is not congruent with the concept of 'higher education' outlined above: it is therefore necessary to give reasons for 
rejecting the model. ${ }^{1}$

Briefly, the main objection to identifying

'educated man' wi th 'rational man' is that there is much more to life than engagement in reflective contemplative thinking. Indeed, reasoning (in the sense in which it features in the dootrine of 'knowledge for its own sake') plays a quite small part in daily life and is raxely at the centre of those experiences and activities which, either at the time or in retrospect, we recognize as being most valuable and memorable. This is a striking fact which is simply ignored in rationalistic conceptions of education and in views of the good life which see it largely in terms of 'the life of reason.' liost of the pleasures, satisfactions, enjoyments and excitements of life do not depend at all upon the forms of reasoning associated with scholarly activity as some educational theorists would have us suppose; on the contrary, they may be sought and obtained by those whose skill in formal reasoning and lnowledge of what Hixst calls 'forms of lenowledge' is very limited.

It might be argued that this is to be regretted and that people should devote more of their time to abstract

1. An interesting paper by Alken, published too late to be talcen full account of here, reaches somewhat similar conclusions: H.D. Aiken, 'Rationalism, Education and the Good Society', Studies in Philosophy and Education, VI, 249-281, 1968. 
thought, or even adopt the pursuit of knowledge for its own sake as a form of life. But what reasons could be offered in support of such a claim? It is one thing to attempt to make rational decisions rather than act upon the fancy of the moment or the result of tossing a coin, but it is quite another to say that man's highest good is engagement in reflective thinting. Mis would be to inflate the place of reason in our experience out of all proportion to its significance and to the exclusion of the many other elements in life which we value. Yet this is precisely what we are Invited to do by those who propound rationalistic theories of education. I am not, of course, advocating a flight from reason in the sense of urging a retreat into mysterymongering and obscurantism: all that $I$ an suggesting is that much of our educational theorizing has become unbalanced through peying undue regard to a one-sided view of human potentialities.

Even the received view is inadequate in terms of its own ideal of rationel action unless 'action' is to be conceived only in relation to the task of thinking rather than in terms of the much wider notion of a person acting in the world with all that involves by way of knowledge, feelings and commitment to values. I have pointed out earlier that the educational expression of such a narrow 
interpretation is clearly visible in that approsch to secondary and higher education which sees intellectual. training as consisting in the offering and grasping of explanations and descriptions which are uninfected by any suggesting that understending can (and often ought) to lead to action. Thus is resson isolated from the buriness of living and students are encouraged to adopt the posture of Rodin's thinker and become absent-minded spectators of the life which goes on around them.

If education is a preparation for the enjoyment of a variety of worthwhile forms of life then it must take account of this veriety and promote a broad spectrum of potentialities. ${ }^{1}$ This means that in the university as well

1. The primary aim is to lot all men have an open view, to give them the materiel and spixitual opportunity to develop their ideas in such a manner thet the elasticity, the inventiveness, the phantasy is retained that makes intelifigent children such delightrul (and for a specialist somewhat embarrassing) company. A specialist study as it is demanded from the scientist today does not seem to me to be compatible with this aim.... such study while preserving inventiveness in a narrow field restricts it in other fields at the expense of a balanced development. Specialism and the openness of mind ... so admired by the Greeks ... these two things do not go together. Here Aristotie was perfectly right. One of them must give and I am in favour of abandoning specialization.... [Eventualiy routine work will] $\ldots$ be reduced to a minimum and then the freedom, the charm, the beauty of Greece would once more be with us and with all of us. And we would but pity those who instead of participating in the free play of metaphysical speculation, in the enjoyment of theatre, wine, song, saw their life tasts in the further development of some recondi te subject.' P.T. Feyerabend, 'On the Improvement of the Soiences and Arts and the Possible Identity of the Two', in R.S. Cohen and If. T. Wartofsky (eds), Boston Studies in the Philosophy of Science, vol. iif, Doxdrecht, Reidel, 1967, pp. 413-414. 
as in the primary school the curriculum mat make provision not only for a wide range of theoretical activit3 es designed to develop the intellectual grasp and understanding required for democratic action and subsequent professional training but also for worthwhile practical activities of all kinds in order to make evident the potentialities of a great variety of forms of life. In oxder to make these possibilities of thought and action meaningful. there will need to be a drastic re-structuring of the curriculum in both schools and universities and the abandoment of the highly specialized studies which are how such a conspicuous feature of education in England.

If higher education is not to be treated, as it undeniably is at present, as a preparation for a life of scholarship or some other form of professional activity but rather as being, as ortega claimed, what is needed by the ordinary man in order to become an autonomous person and social being then entrenched attitudes towards the problem of accessibility will bave to be changed. The Robbins Comittee's proposals for expansion were at least based upon an egtimate of student demand (al though it did not occur to them that these demands might also be extended to the curriculum and the power strueture) rather than on the old elitist notion of the 'pool of ability', but they failed to appreciate both the extent to which this demand is 
Increasing and, moh more important, the possibility of enlarging the demand through a major assault upon the only too familiar inegualities of opportunity throughout the educational system. Iven if the latter be discegarded it Is currently predicted that in 1977 there will. be 23 per cent of the age group in senior sixth forms and the majority of these will alnost certainly wish to go on to higher education. By the end of the century we could well be epproaching the current situation in the U.S.A. where around 48 per cent of the 18-21. age group are attending institutions of higher education: if this does eventuate then the means to meet such a demand will scarcely be provided if some of the present attitudeg towards the evailebility of higher eduostion persist to the end of the century. 1

1. Views which were widely held only twenty years ago already sound like echoes from another age. Jeffares, for example, writing in 1949 , claimed that many students no longer come from oultured homes 'and axe hot fit for University life in the old sense of the word, as it used to be lived in the traditions of Christian-Hellenism or Liberalism. They are a product of the desire for universel education, which logically carried out leads to a demand for higher education for those who are intellectually unfit for it.' A.N. Jeffares, 'Problems Confronting British Universities', in quaestiones Academicae Hodiernae, Groningen, Nolters, 1949, p.55. Similarly, Barker described the university as containing a mixture of ' the man from a home of old culture and manners and the man who has to start from scratch in making his ow culture and menners .... If you make the poor and those who start from scratch the vest majority, you may be doing them an injustice.... You may melke them too many to get the benefit of any real contact with the others, who will then be reduced to a small minority - a minority too small to be able to give.' E. Barker, British Universities, London, Longmans, $1946, \mathrm{p} \cdot 34$. 
A concept of higher (or tertiary) education which refers to the culmination of a process begun in the primary schools clearly requires us to envisage, and to work for, a situation in which higher education for all is a reality since its restriction to en elite would be as indefensible as denying primary or secondary education to a small and largely socially selected section of the population. But in order to bring this about we shall be forced not only to change the charecter of the education at present offered by the universities but also, in the near future, to make some major policy decisions regarding the nature and provision of suitable institutions in which higher educatbon may be provided. The accommodation of a possible one milion students by the end of this century, a time which is rapidy becoming the near future, will require the whole system of higher learning to be radically re-structured. I shall now suggest some of the ways in which this might be done to best adventege.

Some Proposels

Let us begin by looking at the realities of contemporary universities. I have tried to show that they are attempting to provide a home for at least five distihct activities: scholarship, applied research, higher education, professional training, and unrestricted criticism of the 
host society. In chapter III it was suggested that these activities tend to get in each others' way and that they are by no means mutualiy supportive and inter-dependent. As far as most students and many staff are concerned, the old ideal of the university as a community of scholars has become little more than a bed joke. Ilost universities have become too big for any sense of community to be sustained, even at the faculty or departmental level. The specialized nature of many courses, the authoritarian cheracter of the typical teaching transaction, the bureaucratic way in which decisions are taken, and the confining and competitive nature of the examination system all combine to inake the university appear to students as being a school writ lasge. Turthermore, the increasing tendenoy of universities everywhere to concern themselves more deeply with meeting society's demands for trained specialist manpower (renlected in current talk about 'productivity' and use of 'plant'), has the effect of gredually converting universities into institutions which are rather like factories which close at five in the evening and bolt their doors at the weekends. This leads students to perceive the university not as an alma mater which treats them as persons but as the offshoots of buginess and commercial interests designed to shape them into cogs to be slotted into the industrial 
machine. They are confirmed in this belief by the attitudes of many of the staff which appear to be little different from those of business executives and managerial. entrepreneurs. ${ }^{1}$ Educationel natters and teaching responsibilities are seen to be neglected, and the personal relationships and sense of engagement in a comon enterprize which should characterize a community are attenuated to the point of non-existence. All of this has been widely recognized and loudly denounced for some time, yet little is done about it despite evidence that the situation is steadily detexiorating.

\section{What should university people do about this?}

They ought first to appreciate that they cannot pogsibly be all things to all men; this would be a first step in deciding which of their present functions the universities should continue to fulf1l and which would be better carried out by other institutions. It is not easy to see how such decisions are to he made since it is notoriously difficult to make radical changes to ancient institutions, yet the need for such changes appears inescapable. In the earlier

1. An American commentator has said that the new generation of univergity teachers '... has been moved not by a vocation for teaching and scholership but by status, secretaries, kudos, foundation finance. Thy should the behaviour of such professors differ from that of any corresponding convention of managerialists?' I.S. Feuer, 'The Multiversity Ideology and Reality', Quadrant, IX, 43-48, 1965, p.46. 
sections of this thesis I tried to claxify the nature of the various activities for whioh the universities currently make provision in order to bring out what is at stake in the distribution of responsfibilities within the system of higher learning, and I suggested in chapter III that this helps us to determine which of these are mutually dependent and which are liable to be in conflict. My conclusion was that professionel training and applied research are closely allied, as are scholarly activity and specialized post-graduate training, but that higher education tends to be incompatible with all of these. The consequence of mixing them all in the one institution is that none of them tends to be do ne well, and even if one or two of them flourish this is usually achieved only at the expense of the others. There is therefore a strong case for rationalizing the university's responsibilities by allocating some of these to other sectors of the system of higher learning.

But this obviously cannot be done effectively without re-organizing the entire system since the universities do not, and ought not, to, exist in isolation from the rest of the sygtem - a point firmly grasped by the Robbins Comittee. So let us lirst consider what a blueprint for the future development of the system would look like. Unfortunately, as a result of historical factors and a number of recent disastrous policy decisions 
the system as it stands is in a mess, ill-suited in many ways to carry out the tasks required of it and poorly equipped to stand the load which it will have to bear during the next fifty years. However, given these tasks we should be able to indicate those institutional arrangements best suited to them.

If we consider the provision of higher education first we are at once confronted with the sheer size of the anticipated student body towards the end of this century: this could well approach one million. ${ }^{1}$ Educational planners have yet to face up to the implications of this simple fact for the kind of institutions which we have at present: existing institutions would be quite incapable of coping with such numbers unless they are changed out of all recognition. This suggests that, given the view of higher education taken here, we need a new type of institution which will be devoted almost entirely to teaching and learning. Some of the liberal arts colleges in the United States provide obvious models, even though the Robbins Committee chose to reject them. Assuming a student population of one million and an institutional size limit

1. For projections of future demand for places see: University Development 1962-1967, Report of the University Grants Committee, London, H.M.S.O., 1968. 
of 3,000 students we would probably require about 350 of these Colleges of Highex Education by the year 2000 !

But the immediate prospects are not quite so al arming for the government's economists since many existing units can simply be converted to serve othex functions. The universities, for example, will be free to concentrate upon pure research and the training of future scholars and teachers who will work in the Colleges of Higher Education. Even allowing for the fact that there are over 20,000 postgraduate students (excluding those studying education) at the present time and that this number is growing rapidy there is clearly no need for the existing number of univergities. The Robbing Committee's rejection of the idea of a new type of college and their unimaginative insistence upon recomending 'more of the same' in urging the creation of the new universities will undoubtedly be seen as. the worst educational decision of this century. But there is still time to put things right by persuading the new universities (and a number of the older ones) to become Colleges of Higher Education.

Many of the remaining undergraduates could be accomodated in some of the lerger colleges of education which could readily be similerly converted. The rest of these colleges could then concentrate upon the task of training teachers once they have shed their B.Bd. courses 
(the decision to egtablish these was another major error of judgment) and 'main course' work.

If all provision for professional training is removed from the universities this can then be placed where it really belongs - - in special institutions devoted to it and to the applied research upon which successful practice is increasingly dependent. There are great possibilities for imaginative developments here. Colleges of education, for example, could grow into centres which provide initial. training and refresher courses for teachers, opportunities for study at en advanced level closely geared to professional. problems, and facilities for a wide range of applied research activities. Medical training could be centred around a teaching and research ingtitution, a teaching hospital, health centre, and so on. Similar arrangements could be made for legal training, music, art, drama, management, social work and other major professions. Alternatively, preparation for a number of these professional tasks could be brought together in the new polytechnics. This would give these institutions a coherence and sense of purpose which they appear to lack at the moment, bent as they are on aping the worst features of the universities after struggling out of some of the narrow and irrelevent traditions of the technical colleges. 
A re-distribution of responsibilities along lines such as these would transform and invigorate the exigting ramshackle system of higher learning by encouraging each type of activity to flourish in an appropriate milieu. instead of being conjoined with activities with which it shares little in common. Higher education could at last be given the plece which it deserves as the apex of the educational system, professional training could be taken reelly seriously without the distractions of misconceived 'liberalizing' influences, applied research could proceed (as now) in industrial and government sponsored establishments and be greatly extended in professionel training institutes, and scholars could go their way undisturbed (except by post-graduate students from time to time) in the universities.

But the notorious inertia of existing institutions combined with the consequences of the wrongheaded decisions which have been made in recent years make it highly unlikely that any such drastic re-structuring of the system will take place in the near future, however desirable such a change may be. Nothing will be done until we are overtaken by events in the 1990's. So, laying aside the blueprint, I shall abandon speculation and consider what might reasonably be done in the immediate future. 
The universities cannot possibly continue as they are: at the very least the curriculum must be proadened, teaching methods 100 sened $u p$ and the worst evils of the examination system mitigated. This would cost nothing and could be undertaken now. They should also attempt to shed some of the work which they now do by way of professional training since this gets in the way of the requirements of both scholarship and higher education. Responsibility for the training of teachers, for example, could very well be handed over to the colleges of education and the polytechnics. Given sone encouragement, the polytechnics would probably also be willing to take over some of the courses which universities provide for those interested in social. work, management studies, public administration, forestry and agriculture, computer development, etc. Some way must also be found of reducing the demands made on the universities for aid with applied research since the meeting of such requests inevitably means that teaching respongibilities are neglected. But this would be at best only ad hoc tinkering, what Ortega called 'mere touching up of this house of ours', and clearly could not really touch the basic problems: in order to resolve these a radical re-construction of the whole system of higher learning is demanded and I do not see how this can possibly be avoided 
in the long mun. The universities axe old forms trying desperately to keep up with the times: a race which they are patently incapable of winning. Meanwhile, there can be little doubt that, of all their functions, it is higher education which tends to suffer most. I have tried to show why this is so through an examination of some of our fundarnental 1 deas and ways of thinling about the universities and the education which they offer. Until we have cleared our ininds about what it is that we seek to achieve in higher educetion then policy decisions will. continue to be made on the basis of theoretical foundations so feeble as scarcely to mexit serious attention. 


\section{BIBLTOGRAPHY}

\section{Reports and Official. Publications}

Children and their Primery Schools, vol. 1, Report of the Centrel Advisory Council for Education (England), London, H. $.0 .0 ., 2967$.

Comittee on Higher Eduostion, Hicher Educetion: Report, London, H. I. . .0., 1963.

Enquixy into the Mow of Candidates in Science and Technology into THeher Eduextion, [Dainton Report], London, H. I. . . . . 1968. $\frac{\text { The Dow into Bmployment of Scientists, Mngineers, end }}{\text { Technologists, [Swenn Report], London, H. } . .0 ., 1968 .}$

General Educetion in a Pree Societz, Cembridge, Hass. Harvard University Tress, 1945; and London, Oxford Unlvereity Prese, 1946.

Hearings before the Sub-committee on the Re-oreanisation of International oxgenisations $1962-1963$, washington, D.C., U.9. Coverninent Printing office, 1965.

MacFrarlane, J.A. et el., Medical. Bducation in Conada, Royal Commiseion on Health Sexvices, Ottawa, queen's Printer, 1965.

On the Best Means for Promoting Scientific Bducation in Schools, Report made by the British Association for the Advencement of Science, tondon, H. . . . 0., 2868.

Great Britain, Parliamentary Papers, vol. XXI, 1864.

The Problems Facing $3 x+$ th Universitieg, Report of a Nuffield College Committee, Iondon, Oxford University Press, 2948.

Report of the Committee on the Structure of the First and Second Dublic Examinations, Oxford, The University Press, 1965. 
Report of the Committee on University Feaching Hethods, Iondon, H. . S.0., 1964.

Report of the Inter-Devartmental Cormittee on Hedical Schoolg, London, H.ll.S.0., 1944.

Report of the Royal Comisation on Endowed Schools in Ireland, London, 1858.

Report of the Royal Cormission on Medicel Bducation 1965-68, London, H.I. S.0., 1968.

Teaching llethods in Australian Univerg1 bies, Australian

Vice-Chancellors' Comittee, Ilel bourne, 1965.

Tertiary Bducation in Australia, vol. 1, Report of the Committee on the Ruture of Iextiary Bducation in Australia to the Australian Universities Comission, Canberra, Government Printer, 1964.

Univergities and Industry, London, Confederation of British Industxy, 1967.

Univergity Development 1962-1967, Report of the Univeraity Grants Committee, London, H.Ul.S.0., 1968.

University of East Anglia: 1966-7 Prospectus.

University of Essex: Prospectus 1967-8.

University of Kent at Canterbury: Prospectus 2967-68.

University of Lancaster: Prospectus 1967-68.

University of Oxford, Report of Comission of Inquiry, vol. i, Oxford, Clarendon press, 1966.

University of Merwicks Prospectus 1967-68.

University of York: $1967-8$ Prospectus. 


\section{Books and Articles}

Adelstein, D.,
Afreh, R.,
Alken, H.D.,
Allen, Phyllis,

Allen, Fhyliss,

ef

Almond, H.H.

Aragon, L.e,

Archambault, R.D.,

Aristotle,

Army tage, *H. G. ,

Arnold, Mi. ,
- Criais in Higher Bducation: the Roots of Revolt', in D. Adelstein (ed), Teach Yourself Student Dower, London, Radical Student Alliance, 1968.

letter to the Times, 25 Jamuary 1968.

'Rationaliam, Education and the Good Society', Studies in Philosophy and

Medical Bducation in Seventeenth

Century England', Journal of the History of lledicine and Allied geiences, I, 115-143, 1946.

- Scientific Studies in the Bnglish Universities of the Seventeenth Century', Journal of the History of Ideas, $x, 219-253,1949$.

Vir. Lowe's Bducational Theories

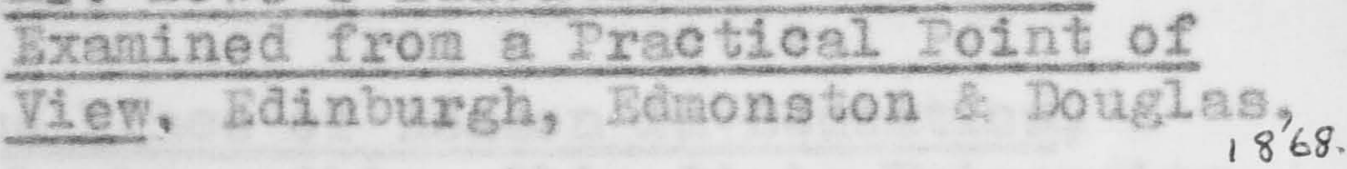

The Hany and the Few", in Replections on our Age, lectures delivered at the opening session of UNBSCO, 1946, London, Wingate, 1948.

- Criteria for Success in Moral

Instruction', Harvard Bducational Review, XXXIII, 472-483, 1963.

Dolitics.

Civic Universitieg, London, Benn, 1955.

Discourses in America, New York, 
Arnold, $\mathbb{Z}$.

Arnstine, D.

Atrineon, D. ,

Austin, J.lie,

Balex, K.

Bal.

$n$

Bandman, B.

Bentock, G.H.,

Berkex, B.,

Barth, J.

Bedford, E.

Be11, D.,
Culture and Anarchy, (edibed by J. Dover (1son), Cambxidge, The

University Press, 1.948 .

'Review Article -- The Carbography of Boucation: R.S. Peters" Sthics and Educetion,' Educetional Theory, IVII, 184-194, 1968, p.188.

The Case fox Student Dower and Student Rights", The Mnes, 1. Ootober 1968.

'A Plea for Excuses", in A.B. Thite (ed), The Philosophy of Action, Iondon, Oxford University Press, 1968.

The Moral Point of VIev, Ithece, N,I. Comnel1 University Pxoss, 1958.

Origln and History of the lathematical Ixipos, Canbridge, The Univexsity Tress, 1880.

Cambridge Papers, London, Hacmillan, 1918.

The Race of Reason in Edueation,

Columbus, Onio, Ohto State University Dress, 1967.

Education and Values, tondon, Baber 1965.

British Universities, London, Longuens, 2946.

The Ind of the Road, Harmondswor th, Penguin Books, 1967.

'Bthotions', in D.G. Gustafson (ed), $\frac{\text { Esseys in Dhilosophicel Psychology, }}{\text { London, Iremillan, } 1967 .}$

The Reforming of General Bducation, New York, Columbia University Press, 1966. 
Benn, S.I. and

Peters, R.S.,

Bibby, C.,

Breed, F.S.,

Brierly, J.L. and Hodson, H.V.,

Briggs, A.,

\begin{abstract}
$n$
Brogdie, F.,

Brougham, H.,

Bruner, J.S.,
\end{abstract}

Butcher, H.J. and Pont, H.B. (eds), Cajoxi, R.,

Campoell, M.B.,

Cannon, F.T.,
Sociel Principles and the Democratic State, London, Allen \& Unwin, 1959.

T.H. Huxzey: Scientist, Humanist and Educator, London, Watts, 1959.

Bducation and the New Realism, New York, IIacrillan, 1939.

'Literae Humaniores', in the Handbook to the University of Oxford, 1962 , London, Oxford University Press, 1962.

The Nap of Leaming, Canberra, Australian Netional University, 1961.

'Drawing a New Nop of Learning', in D. Deiches (ed), The Idea of a New University, London, Deutsch, 1964.

'Trying and Doing', Droceedings of the Aristotelian Society, bXVI, 27-40, $1965-6$.

$\frac{\text { Objects, Advanteges, and 2leasures of }}{\text { Science, London, Baldwin \& Cradock, } 1829 .}$ The Conditions of Creativity', in H.E. Gruber (ed), Contemporary Approaches to Creative Thinking, New Jork, Atherton Press, 1963.

Educational Research in Britain, London, University of Jondon Press, 1968.

Matheratics in liberal Education, Boston, Christopher, 1928.

Nonspecialist Study in the Undergraduate Currioula of the New Universities and Colleges of Advanced Iechnology in Bngland, Ann Arbor, Michigan, University of Mchigan School of Education, 1966.

- The Normative Role of Science in Larly Victorian Thought?, Journal of the History of Ideas, XXV, 487-502, 1964. 
Cardwell, D.S.L.,

Cavanegh, $\mathbb{F} \cdot \mathrm{A}$. (ed),

Cave, R.G.,

Charlton T.,

Clarke, M.L.,

Cody, A*,

Conant, J.B., $-$

Cooper, Joan,

Corbett, J.?.,

Corry, J.A.,

Costello, \%.?.
The Organisation of Science in Bngland, bondon, Heinomann, 1957.

Spencer on Education, Cambridge, The University Press, 1932.

A11. Their Future, Hexmondsworth, Penguín Boolss, I968.

Tiberal Education and the Inng of Court in the Sixteenth Century', British Journel of Bducational Studies, $\mathrm{IX}, 25-38,1960$.

Classical Bducation in Britain 15001900 , Cambridge, the University ress, 1959.

- Can a Single Action Have Hany Different Desoriptions? Inquix, $x, 164-180$, 1967.

Bducation and Iiberty, Cambridge, Nass., Harvard Univeraity Iress, 1953.

'Confusion Confounded by Politielans', Pines Educational Supplement, 29

November 1968.

'Criteria for Successful Teaching', Proceedings of the Philosophy of Bducation Society of Greet 3ri.tein 1966 , $5-18,1966$.

'Opening the Hind', in D. Daiches (ed), The Idea of a New University, London, Deutsch, 1964.

'Tniversities' only Security is in Dublic Opinion", University Affairs, $x$, No. $1,18-19,1968$.

The Scholastic Curriculum at Early Mass, Seventeenth century Cambricge, Cambxidge, Harvard University Press, 1958. 
Cotgrove, S.,

Craig, D.,

Crick, B.,

Crow ther, J.G.,

Cunming, I.,

Curts.s, M.H.,

Gurzon, Lord,

Davie, G.B.,

Devies, D. ,

Dewey, Jै,

Dobrée, B.,

Bddy, E..D.,

Bawerå, ม.B.,

Brikson, B.. H.,
'Bducation and occupation', $\frac{B x \text { tish }}{33-42,96}$ Journal of Sociology, XIII, $\overline{33-42,1962 .}$

'Teeping it Hew', The Ilstener, 489-491, 17 october 1968.

'student Tower', The observer, 10 November 1968.

Statesnen of Science, London, Cresset Jxeas, 1965.

A llanufactured than: the Education of John Stuart 111, University of Auolland Bazle tin 10. 55, Auctiond (New Zealand), 211 grim Press, 1960.

Oxford and Cambridge in Trangition 15581642, Oxford, Clarendon Press, 1959.

$\frac{\text { Prineiples and Hethods of University }}{\text { Beform, Oxford, Clarendon Jxess, } 1909 .}$

The Democratic Intellect, Batnburgh, The University ress, 1961.

'A Scarce Resource Colled Curiosity', The Iistener, 4 Moy 1967.

How He Thank, New York, Heath, 1910.

'Artg Faculties in Hodem Universities', Dol1ticel cuerterly, XV, 341-352, 1944.

The College Innluence on Student Character, Neshington, D.C., Arexican Council on Bducetion, 1959.

Bat torial, New Soeiety, 24 December 1964

'Some studies of the Moral Development of Children', Bducational Research, VII, $200-211,2965$.

Chilchood and Society, New Iork, Norton, 1950. 
Febex, G.,

gaxberow, N. (ed),

Farxax, F.W. (ed),

Bawthrop, I.

Feuex, I.S.

ley exabend, P.R.. ,

Mew, A.G.N.,

Foot, Philippa (od),

Boote, G,

Ruthex, J.2.

Bulton, J.S.,

Galbra1th, J.T. ,

Glover, Mary,
Jowett, London, Paber, 1957.

Zaboo Jopics, New York, Atherton Press, 1963.

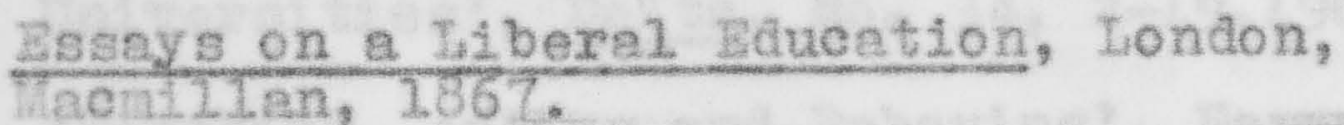

Eduention and Exaninations, Fondon, Fadical Student Allíance, 1968.

'The 1ul tiversity - Ideology and

Reality', quadrant, (Australia), IX, 43-48, 1965.

'On the Improvement of the Sciences and the Arts and the Dossible Identity of the Two', in R.S. Cohen and Il. W. Warto fstky (eds), Boston Studies in the Philosophy of Seience, vol. 11i, Dordrecht, Reidel, 1967.

'That is Indoctrination", Studies in Thilosophy and Education, IV, 281-306, 1966.

Theories of Ethios, London, Oxford

- Science and its Tunetions in Tarly Nineteenth Century England', Osiris, XI, 433454, 1954.

'Hunphry Davy's Adversaries', Chymia, VIII, 147-164, 1962.

- The Future Pattern of University

Eduestion in the Uni ted Kingdom', Journal of the Royal Society of Axts, Grx, I961.

'Tew Universities in Perspeotive', in D. Daiches (ed), The Idea of a Mew Univeraity London, Deutsch, 1964.

'The role of the State', the Listener,

8 December 1966.

'Educating for Hunan Understanding', in Harjorie Reeves (od), Bighteen Plus, London, Faber, 1965. 
Golombelk, H.

Coman, A.,

Green, S.F.,

औด

Creen, V.H.H. ,

Griffiths, A.D.,

H

Crotjahn, H.,

Guilford, J.2.,

Guthrie, Eiv.,

Hale, sir. Bdwerd,

Hencliton, $\pi$,

Harmphixe, S.,

Hexe, R.II.,
The Value of Imegination", The Times 1. April 1967.

Dublict ty ox Promises the New Universities', Delta, Mo. 34, 2-19,1964.

Teaching, Acting and Behaving", Harvard zäuational Revier, XoxIV, 507-524,1964.

"A Topology of the Teeching Concept", Studies in Philosophy and Bduontion, IIT, $284-319,1964$.

Oxford. Common Room, London, Edwerd Amold, 1957.

"Justifying lloral Pxineiples", Proceedings of the Axistotelien Society, IVIII, 103-124, 1957-58,

A Deduction of Univergities', In R.D. Archambault (ed), Philosophical Analysis and Bäncstion, Jondon, koutledge, 1965.

Boyond Laughter, New Ioxis, MoGraw-H11.1, 1957.

'Txuits of Creativity', in H.H. Anderson (ed), Creativity and its Cultivation, New Iork, laxper, 1959.

The vraluation of Teaching, Seattle, University of ash ngton, 1954.

The Report of the Comnittee of Univereity Teaching Methods", Home Universitues Conference 1964.

Discusstons on Philosophy and 1Lterature, Bducetion and Universit ty Meform, Bdinburgh, Machachlan \& Stewart, 1853.

Thought and Action, London, Chatto \& Tndus, 1959.

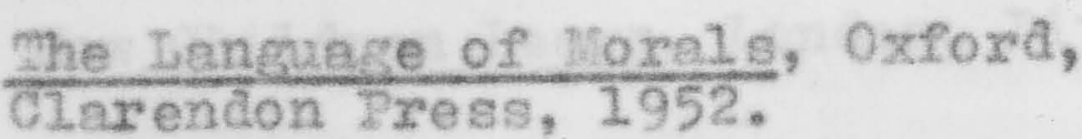


Haxe, R.M. ,

is

Hexrod, R.F.,

Hartley, Sir

Harold (ed),

Haxtmann, H.,

Hayden, T.,

Hotherington, H.

Himmel farb, Hilda,

Hixst, P.H.,

4

$n$

Hoggart, S.,

Holt, J.,
Freedom and Reason, Oxford, Clarendon Press, 1963.

'Adolescents into Adults', in T.H.B. Wolling (ed), Aims in Fducation, Manchester, The University Iress, 1964.

The Prof, Zondon, Mamillan, 1959.

The Roysl Society: its Oxigins and 1960.

$\frac{\text { Bgo Psychology and the Problem of }}{\text { Adaptation, London, Imago, } 1958 \text {. }}$

- Student Social Action: from tiberation to Community', in D. Adelstein (ed), Teach Yoursel. Student Power, Tondon, Radical Student AIliance, 1968.

$\frac{\text { The Social Function of the University, }}{\text { London, Lindsey Press, } 1953 \text {. }}$

letter to The Iistener, 23 March 1967.

'Philosophy and Bducational Theory', British Journal of Educational Studies, XII, 51-64, 1963 .

- Jiberal Bducation and the Nature of Knowledge', in R.D. Archambarlt (ed), Philosoohical Analysis and Bducation, London, Routledge, 1965.

The Contribution of Philosophy to the Study of the Curriculum', in J.F. Rerr, (ed), Changing the curriculum, London, University of Jondon Press, 1968.

'Cambridge Anti-memories', The Guardian, 17 October 1968.

How Children Pat1, New Yorts, P1tman, 1964. How Children Learn, Jondon, Pitman, 1968. 
Fudson, I. ,

Hunt, R.,

Iunter, J.I. H.

Hutchins, R.MH.

4

Huxley, I. I.

n

Jacks, M. .I.,

Jackson, B.,

Jacob, P.E.

Jeffares, A.N.,

Johnson, D.C.,

Johnson, D.MI.

Johnson, H.C.,

Johnson, H.G.,
Contraxy Imaginations, London, Methuen, 1966.

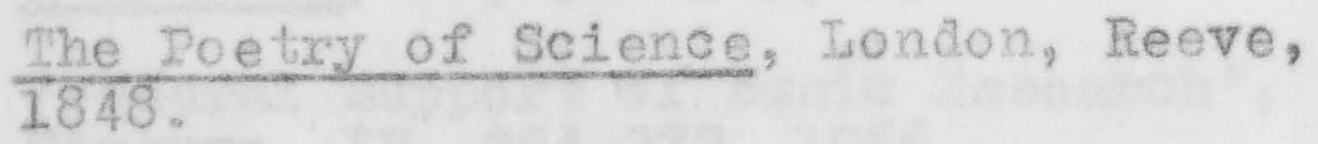

"Porms of life" in Witgenstein's $\frac{\text { Philosophical Investigations' }}{\text { Philosophical Querterly, V, }} 233-243,1968$.

the Higher Leaming in America, New Haven, Conn. Yale University Press, 1936. Bducation for Freedom, Baton Rouge, Louisiana State University Dress, 1947.

Science and Edueation, London, Mamillan, 1893.

Man's Place in Nature and Other Bssays, London, Dent, 1906.

Total Education, Iondon, Kegan Paul, Treneh, Irubnex, 1946.

'Dlowden and the Univexsities', Universities Quarterly, XXI, 373-375, 1967.

Changing Values $1 \mathrm{n}$ Coliege, New York, Harper, 1957.

- Problems Confronting British Universi-

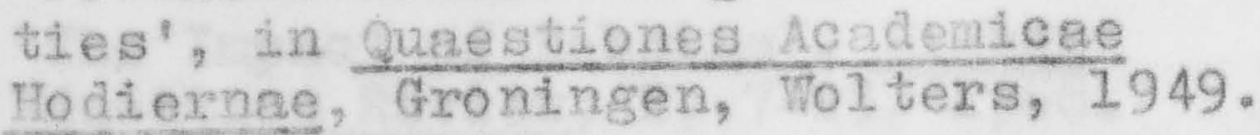

New Bradford Course Prepares Students for Industry', Mimes Bducetional Suplement, 13 September 1968.

The Psychology of Thought and Judgment, New York, Harper, 1955.

'Are Our Universities Schools?' Harvard Educational Review, XXXV, 165-177, 1965.

Federal Support of Basic Research: Some Economic Issues', Minerva, III, $500-514,1965$. 
Kaufman, A. $; \cdot$

Roy axt,

Rel.1y, B.the,

Eexneghan, I.

Kerr, O.,

Tneale, $"$. C.

Koentlex, A.

Tonisax, B.2.,

Leuprecht, S.P. ?

I.Eycxd, R., and

Ting, J.,

Iesch, B.Re?

Leevis, F.R.,

कै

Irevi-Stxauss, O.
' Zenching as an Intentionel. Sexisl.

Pexpoxmance", Studies in Philosobhy and Bducat1on, IV, 361-389, 1966.

'Pederal Support of Basid Research', 111.nexva, IV, 254-272, 1966.

- Transfex of Training: an Analytic Study", in B.P. Tomisex end C.J.B. Promillan (eds), Bgycholomical Concepts in Bchostion, Chicogo, Rand Clnily, 1967.

Apethy Anoncet phygice Students, (mineoed), Inncheaver, 2968.

The Uses of the University. Cambxidge, hess. Harvard Univexstty sress, 1963.

On Heving a Hnd, Iondon, Cambridge University 2xess, 1962.

the Act of Crestion, London, Hutchinson, 2.964.

Tenching: Act and Enterprtse", Studles in Dhilosonhy and Educetion, VI, $168-193$, 1968.

The Role of Deccartes in Seventeenth Century Ingland, Colunbis Studies in the Fis story of Ideas, vol. 11., Hew York, Columbia University Press, 2935.

The Impnot of Robbins*, H1 gher Mducation Reviev, I, 7-25, 1968.

"When scientists Pley the Bole of Cod." The Mines, 16 November 1968.

Edueation and the Univexsity, London, Chetto \& Hindus, 1943.

Ietter to The Mines, 22 January 1968.

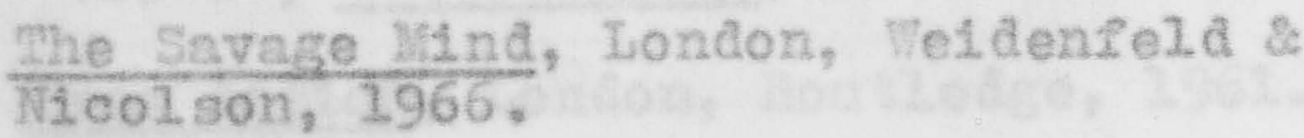


Lew1 $9, C . D$, end

Fenby, C. (eds),

Livingstone, R.,

Locke, J.,

Loring, L. Il. ,

Lowe, R.,

"eCarthy, M.C.,

Hacauley, Lord,

Meduclsen, M.I. ,

Macleworth, N, $\mathbb{H}$.

Marlet, C.B.,

Marcuse, $\mathbb{H}$,

Martin, D.,

Marvin, F.S. (ed),

Heyne, R.,

Heldon, A,I.,

liexton, R.R.,
Anetomy of Oxford, Iondon, Cape, 1938.

$\frac{\text { Some Thoughts on Jnlyergl ty Education, }}{\text { London, Cambridge Universt ty Tress, } 1948 .}$

An Bessy Concerning Huxan Understending;

1690.

Two Tinds of Values, London, Routledge, 1966.

Pxirary and Classteal Bâneation, Bdinburgh, Bdronston \&ouglas, 1867.

The Jhployment of Mtghy Specielised Gradustes, Science Policy Studies No. 3, Departient of sducation and seience, Iondon, H. . . S.0., 1968.

Speeohes, vol. 1, London, Flenry Vizetelly, 2853.

The Catholic Fay in Bducation, Ill 2 waulcee, Bruce Tubitshing Co*, 1937.

'Originality', American Psychologist, $x \times, 51-66,1965$.

A. History of the Univergi by of oxford, vol.11i, London, Oxford Universi ty Press, 1927.

1 whe Father of Student Rebellion"? The Listener, 498-499, 17 october 1968.

Trouble in the University", The Iistener, $291-293,7$ Jlaroh 1968.

$\frac{\text { Reports on BLementary Schools, } 1852=}{1882 \text {, London, H. H. .0. . 1908. }}$

'views', The Listener, 31. october 1968.

Pree Aotion, Iondon, Routledge, 1961.

- Science, Technology and Society in Seventeenth Century Bngland,' Osirig, IV, 2938. 
Mi11, J.S.,

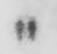

Mitchell, B.,

Moberly, w.,

Montefiore, A.,

Moore, W.,

Murphy, S.,

Nash, P., Kazamias, A.M. and Perkinson, H.J. (eds),

National Union of Students

Newman, J.H.,

$n$

Noble, H.C.,

Norcross, K.,

Oakeshott, M.,

Ogilvie, R.M.,
An Examination of Sir William Hamilton's philosophy, vol. 11, London, 1877.

Inaugural Address at the University of St. Andrews, 1867, London, Longmans, 1890.

Letter to The Times, 6 February 1968.

The Crisis in the University, London, S.C.M. Press, 1949.

'Noral Philosophy and the Teaching of Morality', Harvard Educational Review, XXXV, $435-449,1965$.

'Indoctrination as a Normative Conception', Studies in Philosophy and Education, IV, 396-403, 1966.

Stone Mad, London, Routledge, 1967.

The Educated Man: Studies in the Histoxy of Educational Thought, New York, Wiley, 1966.

1968 Campus Reform Campaign: Campaign Manual, London, 1968.

Essays and Sketches, vol. il, (edited by C.F. Harrold), New York, Longmans, 1947.

The Idea of a University, (edited by $\mathrm{C}$. F. Harrold), New York \& London, 1947.

Book review in Religious Education, IXIII, $\mathrm{p} .408,1 \overline{968 .}$

Letter to The Listener, 29 June 1967.

Rationalism in Politics, London, Methuen, 1962 .

Latin and Greek: A History of the Influence of the Classics on English Life from 1600 to 1918 , Iondon, Routledge, 1964. 
Oxtega y Casset,

Passmore, J.,

Tatterson, R. and Longsworth, C.R.,

Patt1son, M*,

Peston, H.

Deters, R.S.,

if

Pisget, J.,

Pinner, R.,

Polk, K.,

Powell, J.P.,

Rashdal., H.,

Rlobbins, Lord,
Mission of the University, Drinceton, N.J., Jrinoeton Untversity Tress, 1944.

'On Jeaching to be Critlcal', in R.S. Peters (ed), The Concept of Bducation, Iondon, Rout1edge, 1967.

The Making of a college, Cambridge, Hess., T.I.I. Jress, 1966.

Suggegtions on Academicel Organisation, Bdinbures, 1868.

' Quality and. Eguality', Hi gher Bducation Reviev, I, 77-86, 1968.

- Worel Baucation and the Psychology of Charactex', Philogonhy, XXxVII, 37-56, 1962.

$\frac{\text { Bthics and Education, London, Allen }}{\text { Unwin, 1966. }}$

The Yorel Judgment of the Child, London, Tegan Paul, 1932.

The Crisia of the State Universities", in 17. Sandiord (ed), The Ameriem College, ฟew Iork, Wley, 1962.

- Student Drotest in the U.F. and the V.S.' Hi eher Bavostion Reviev, I, 63-67, 1968.

- Experimentation and Teaching in Higher Edueation', Educational Research, VI, $179-191,1964$.

Tutorial Teaching and the University Ideal', Augtralian University, IV, 19-36, 1966.

The Universitles of Burope in the Midale Ages, (edited by ... Iovicke and A. B. Emden), London, Oxford Universt ty Press, 1936.

The Univergity in the Hodern Forld, London, Iacmi17an, 1966. 
Robinson, E.,

Robinson, E., and Jaynes, D.,

Roe, $\mathbb{E}$,

Rogers, C.R.,

Rolt, L.T.O.,

Ross, M.G.,

Rottenburg, S.,

Rubin, F. (ed),

Russel1, B.,

w

Ryle, G.,

i)

n

n

it
The New Polytechnics, London, Cornmarket Press, 1968.

'Pay and the Academies', Higher Education Review, I, 39-54, 1968.

The Development of Tertiary Education in T.P.N.G.', Australian Journal of Education, YII, 58-72, 1968.

On Becoming a Person, Boston, Houghton Miflin, 1961.

Railway Adventure, London, Constable, 1953.

The New Jniversity, Toronto, Toronto University Press, 1961.

The Warrants of Basic Research', Minerve, $V, 30-38,1966$.

Current Research in Hypnopaedia, London, Ilacdonald, 1968.

Education and the Good Life, New York, Tiveright Publishing Corp.9 1926.

Autobiography 1872-1914, Jondon, Allen \& Unwin, 1967.

The Concept of Mind, London, Hutchinson, 1949.

'Thinking', Acta Psychologice, IX, 190196, 1953.

A Rational Animal, Iondon, Athlone Press, 1962.

Teaching and Training', in R.S. Peters (ed), The Concept of Education, London, Routledge, 1967.

Thinicing and Reflecting', in $G$. Vesey (ed), The Human Agent, Iondon, Macmilian, 1968. 
Sandys, J.Z.,

Sanford, N. (ed),

Scheffler, I.,

Sloman, A.E.,

Southern, R.W.

Sparrow, J.,

Spencer, Ho,

Stublos, w.,

Tavlor, P.S.,

Taylor, P.V.,

Thalberg, I.,

Thompson, C.R., $\frac{\text { A History of Classical. Soholarship, }}{\text { Cambridge, The University Press, } 1908 .}$

The American College, New York, Wiley, 1962.

The Ianguage of Education, Springeield, I11., Charles Thomas, 1960 .

A University in the Malking, London, B.B.C. Publications, 1964 .

The Shape and Substance of Academic History, Oxford, the Clarendon Press, 1961.

Merk Pattison and the Idea of a

University Press, 1967.

'What Tnowledge is of Most Worth?' in

E.A. Cavanagh (ed), Spencer on

Education, Cambridge, The University Press, 1932.

Seventeen Lectures on the Study of Medieval and Woderm History, Oxford, The University Press, 1900.

The Teaching of science at oxford in the Nineteenth Century', Annals of Science, VIII, 82-112, 1952.

Woral Vixtue and the Responsibility for Character', Analysis, XxV, 17-23, 1964 .

'Brotion and Thought', in S. Hempshire (ed), Philosophy of Mind, New York, Harper and Row, 1966. $\frac{\text { Universities in Tudor England, }}{\text { Vashington, D.C., Holger Shake speare }}$ Iibrery, 1959. 
Thompson, B.P.,

Thornatike, E.t.,

Thouless, R.,

Tibble, J.W.,

Ti1lyaxd, B.M.W.,

To dhunter, I. ,

Torrance, E.P.,

Toulmin, S.,

Truscot, P.

*

Vernon, P.E.,

Vesey, G.,

Wain, J.,

Wallas, G.,
The Making of the English Working Class, Harmondsworth, Penguin Books, 1968.

Bducational Psychology, New Xork, Lencke and Buechner, 1903.

A Map of Bducational Research in

Britain', Paedagogica Furopaea 1966,

Bdinburgh, Chambers, 1966.

Thye Development of the Study of Education', in J.17. Mibble (ed), The Study of Education, Gondon, Routledge, 1966.

The Muse Unchained, London, Bowes \& Bowes, 1953.

The Conflict of Studies, Iondon, Meomillan, 1873.

Bducation and the Creative Potential, Press, 1963 .

The Complexity of Scientific Choice II: Culture, Overheads of Tertiary

Industry?', Minerve, IV, 155-169, 1966.

Red Brick University, London, Faber, 1943.

Redbrick and these Vital Days, London, Faber, 1945.

'Creativity and Intelligence', Educational Research, VI, 163-169, 1964.

'Conditioning and Leaming', in R.S.

Reters (ed), the Concopt of Education, London, Routledge, 1967.

Sprightly Running, Iondon, Macmillan, 1.962 .

Wen and Ideas, London, Allen \& Unwin, 
Ward, W.A*,

Ward, $\nabla \cdot R \cdot$,

Wamook, Mary,

Wetson, J.D.,

Tebster, B. et alor

Teisberg, H.,

Thewell, W.

White, o.,

m111 ans, R.,

mil1ans, R.,

Milson, Jै,
The Ienguage of Robb' as', The Itstener, 10 Septenis as $7,96,4$.

Yiotorian Oxford, I. sndon, Datax. Cass, 1965.

Eth1os sinoe 1900, London, Oxford Univera1ty Iress, 1966.

the Double Melix, Jondon, Meidenfeld 3.1. colson, 1968,

Te see the University a Servant of Industry and Govemnent?, Universaty, Afrairs, $\pi$, To. 2, p.11, 1968.

'Personality Changes in College Students", in II. Senford (ea), The American College, New Yorle, Wiley, 1962.

Tredition and the Mraditionalist, in

I. Schefller (ed), Philosophy and Bubestion (second edition), Boston, Alyn \& Bacon, 1966.

Thourhts on the study of lathematies og Part of Jibexal Bduca won, Cambri dse, 1835.

Zarliament of a Thousand $2 x 1 \mathrm{bes}$

London, lletnemenn, 1965.

Culture and society 1780-1950, London, Chatto \& indus, 2958.

$\frac{\text { The Iong, Bevolution, London, Chat to \& }}{\text { Indus, 1961. }}$

'Education and Indoctrination', in S.H. B. Holling (ed), Aims in Bdueation,

"Two Types of Tenching", in R.D. Archambault (ed), Philosophicel Analysis and Bduestion, London, Routiedge, 1965. 
Wnstanley, D.A.,

Mittgenstein, L.,

Woolf, I. :

Wordsworth, C.,

Young, D.,

Young, T.,

Ziman, J.M.,

Zuclcermen, S. , $\frac{\text { Darly Vietorian Carbridge, Cambridge, }}{\text { The University Press, } 1940}$.

$\frac{\text { Philosophicel Investigations, Oxford, }}{\text { Blackwell, } 1963 \text {. }}$ Beginning Again, London, Hogarth Press, 1964.

Scholae Academicae: Some Account of the the Highteenth century, Cambridge, The University Press, 1910 .

Try Anything Twice, London, Hamilton, 1963.

A Course of Lectures on Natural $\frac{\text { Philosophy and the Kechanicel Arts, }}{\text { London, Taylor \& Nalton, } 1807 .}$

Public Knowledge, Cambridge, The University Iress, 1968.

Scientists and War, London, Harnish 